EVALUASI FUNGSI EKOLOGIS DAN ESTETIKA

BEBERAPA RUANG TERBUKA HIJAU PUBLIK DI KOTA

TASIKMALAYA

INTAN NUR FATHONAH

DEPARTEMEN ARSITEKTUR LANSKAP

FAKULTAS PERTANIAN

INSTITUT PERTANIAN BOGOR

BOGOR

2018 


\section{PERNYATAAN MENGENAI DISERTASI DAN SUMBER INFORMASI SERTA PELIMPAHAN HAK CIPTA*}

Dengan ini saya menyatakan bahwa skripsi berjudul Evaluasi Fungsi Ekologis dan Estetika Beberapa Ruang Terbuka Hijau Publik di Kota Tasikmalaya adalah benar karya saya dengan arahan dari komisi pembimbing dan belum diajukan dalam bentuk apa pun kepada perguruan tinggi mana pun. Sumber informasi yang berasal atau dikutip dari karya yang diterbitkan maupun tidak diterbitkan dari penulis lain telah disebutkan dalam teks dan dicantumkan dalam Daftar Pustaka di bagian akhir disertasi ini.

Dengan ini saya melimpahkan hak cipta dari karya tulis saya kepada Institut Pertanian Bogor.

Bogor, Oktober 2018

Intan Nur Fathonah NIM A44140011 


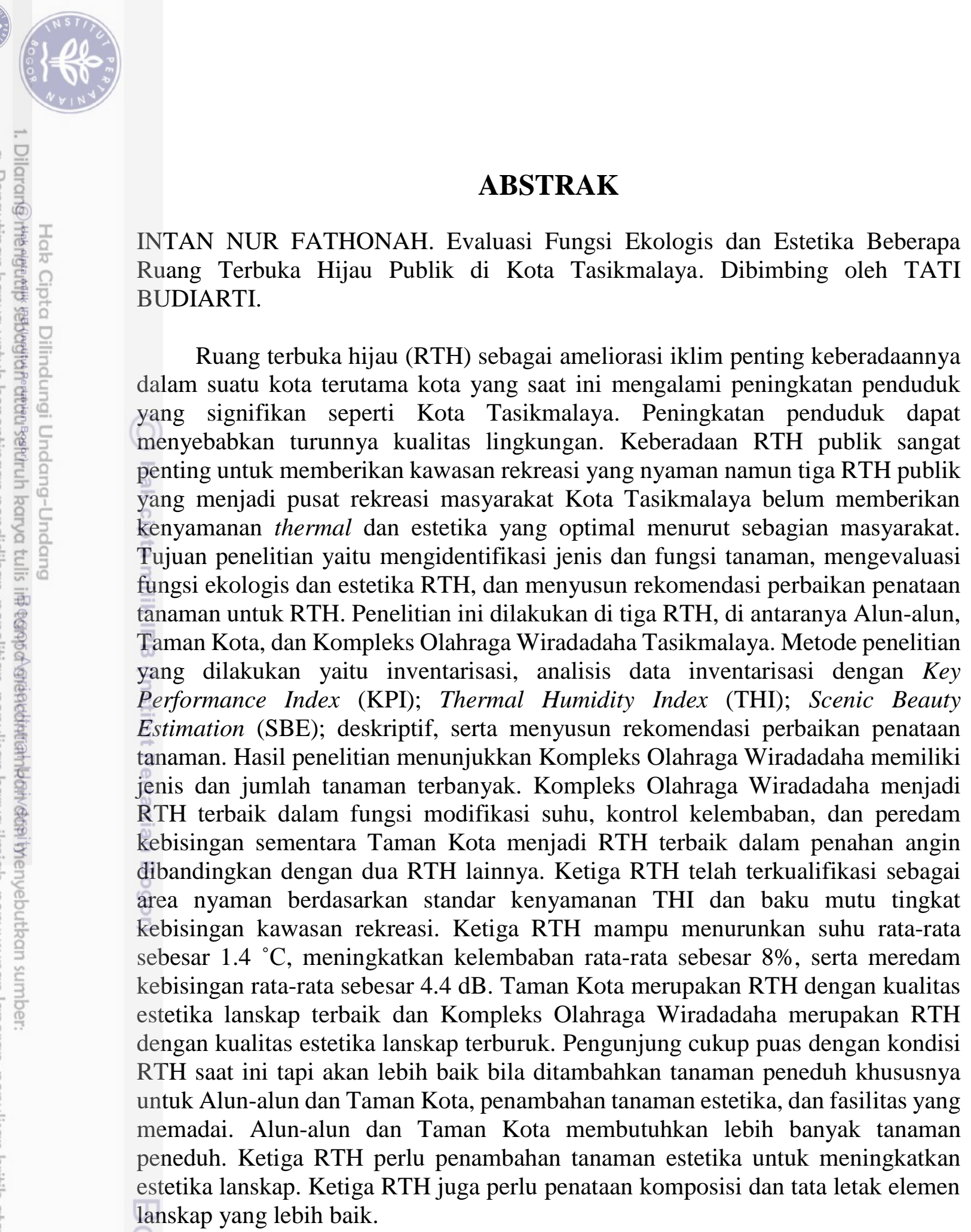

INTAN NUR FATHONAH. Evaluasi Fungsi Ekologis dan Estetika Beberapa Ruang Terbuka Hijau Publik di Kota Tasikmalaya. Dibimbing oleh TATI BUDIARTI.

dalam suatu kota terutama kota yang saat ini mengalami peningkatan penduduk
yang signifikan seperti Kota Tasikmalaya. Peningkatan penduduk dapat
menyebabkan turunnya kualitas lingkungan. Keberadaan RTH publik sangat
penting untuk memberikan kawasan rekreasi yang nyaman namun tiga RTH publik yang menjadi pusat rekreasi masyarakat Kota Tasikmalaya belum memberikan kenyamanan thermal dan estetika yang optimal menurut sebagian masyarakat. Tujuan penelitian yaitu mengidentifikasi jenis dan fungsi tanaman, mengevaluasi fungsi ekologis dan estetika RTH, dan menyusun rekomendasi perbaikan penataan tanaman untuk RTH. Penelitian ini dilakukan di tiga RTH, di antaranya Alun-alun, Taman Kota, dan Kompleks Olahraga Wiradadaha Tasikmalaya. Metode penelitian yang dilakukan yaitu inventarisasi, analisis data inventarisasi dengan Key Performance Index (KPI); Thermal Humidity Index (THI); Scenic Beauty Estimation (SBE); deskriptif, serta menyusun rekomendasi perbaikan penataan tanaman. Hasil penelitian menunjukkan Kompleks Olahraga Wiradadaha memiliki jenis dan jumlah tanaman terbanyak. Kompleks Olahraga Wiradadaha menjadi RTH terbaik dalam fungsi modifikasi suhu, kontrol kelembaban, dan peredam kebisingan sementara Taman Kota menjadi RTH terbaik dalam penahan angin dibandingkan dengan dua RTH lainnya. Ketiga RTH telah terkualifikasi sebagai area nyaman berdasarkan standar kenyamanan THI dan baku mutu tingkat kebisingan kawasan rekreasi. Ketiga RTH mampu menurunkan suhu rata-rata sebesar $1.4{ }^{\circ} \mathrm{C}$, meningkatkan kelembaban rata-rata sebesar $8 \%$, serta meredam kebisingan rata-rata sebesar $4.4 \mathrm{~dB}$. Taman Kota merupakan RTH dengan kualitas estetika lanskap terbaik dan Kompleks Olahraga Wiradadaha merupakan RTH dengan kualitas estetika lanskap terburuk. Pengunjung cukup puas dengan kondisi RTH saat ini tapi akan lebih baik bila ditambahkan tanaman peneduh khususnya untuk Alun-alun dan Taman Kota, penambahan tanaman estetika, dan fasilitas yang memadai. Alun-alun dan Taman Kota membutuhkan lebih banyak tanaman estetika untuk meningkatkan lanskap yang lebih baik.

Kata kunci: fungsi estetika, fungsi ekologi, evaluasi, ruang terbuka hijau 


\begin{abstract}
INTAN NUR FATHONAH. The Evaluation of Some Public Green Open Spaces Ecological and Aesthetical Functions in Tasikmalaya City. Supervised by TATI BUDIARTI.

The existance of green open space as climate amelioration is important in a city with high growth of population such as Tasikmalaya City. Population growth can decreasing environmental quality. The public green open spaces existence is important to give a comfortable recreation area but the three green open spaces, central recreation area of Tasikmalaya society, have not met optimal thermal and aesthetic comfort yet as society preference. The aims of this research is to identify species and function of vegetation, evaluate ecological and aesthetic functions of the green open spaces, and give vegetation improvement recommendations for the green open spaces. This research located in Alun-alun, Taman Kota, and Kompleks Olahraga Wiradadaha Tasikmalaya City. The research methods are inventory, analyse the inventory data by Key Performance Index (KPI); Thermal Humidity Index (THI); Scenic Beauty Estimation (SBE); descriptive, and give the vegetation improvement recommendation. The research result showed that Kompleks Olahraga Wiradadaha has the most species and quantity of vegetation. Kompleks Olahraga Wiradada is the best in modification, humidity control, and noise reducing function meanwhile Taman Kota is the best in wind barrier function than other green open spaces. The three green open spaces qualified as a termal comfort zone based on standard THI and they also have meet the standard noise of recreaction area. Overall they can decreasing the average themperature untill $1.4{ }^{\circ} \mathrm{C}$, increasing the average humidity untill $8 \%$, and reducing the average noise untill 4.4. Taman Kota has the best quality of landscape aesthetic and Kompleks Olahraga Wiradadaha has the worst quality of landscape aesthetic. Visitors satisfied enough with the green open spaces but those can be better with more shaded vegetation especialy in Alun-alun and Taman Kota, more aesthetic vegetation, and better facilitation. Alun-alun and Taman Kota need more shaded vegetation. The three green open spaces need more variation in aesthetic vegetation, and a better landscape elements composition and layouting.
\end{abstract}

Keywords: aesthetical function, ecological function, evaluation, public green open space 


\title{
EVALUASI FUNGSI EKOLOGIS DAN ESTETIKA BEBERAPA RUANG TERBUKA HIJAU PUBLIK DI KOTA TASIKMALAYA
}

\section{INTAN NUR FATHONAH}

\section{Skripsi}

sebagai salah satu syarat untuk memperoleh gelar

Sarjana Arsitektur Lanskap

pada

Departemen Arsitektur Lanskap

\author{
DEPARTEMEN ARSITEKTUR LANSKAP \\ FAKULTAS PERTANIAN \\ INSTITUT PERTANIAN BOGOR \\ BOGOR


Judul

Nama

NIM
Evaluasi Fungsi Ekologis dan Estetika Beberapa Ruang Terbuka Hijau Publik di Kota Tasikmalaya

Intan Nur Fathonah

A44140011

Disetujui oleh:
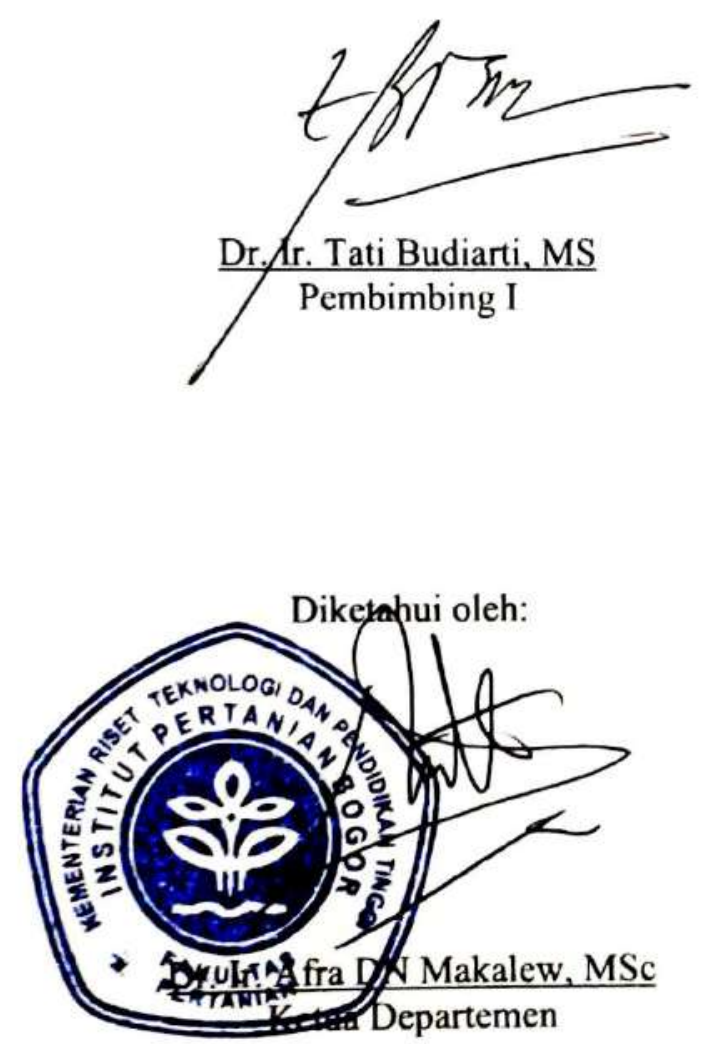

Tanggal Lulus: $\quad 24$ OCT 2018 


\section{PRAKATA}

Puji syukur penulis panjatkan kehadirat Allah swt. karena atas limpahan karunia dan rahmat-Nya maka skripsi yang berjudul Evaluasi Fungsi Ekologis dan Estetika Beberapa Ruang Terbuka Hijau Publik di Kota Tasikmalaya berhasil diselesaikan. Shalawat serta salam juga semoga selalu tercurah kepada junjungan dan teladan kami Nabi Muhammad saw.

Penulis mengucapkan banyak terima kasih kepada Ibu Dr. Ir. Tati Budiarti, MS selaku dosen pembimbing yang telah memberikan banyak saran, dukungan, dan kesediaan waktunya kepada penulis sehingga penulis dapat menyelesaikan skripsi ini dengan baik. Penulis juga banyak berterima kasih kepada dosen penguji, Bapak Dr. Ir. Nizar Nasrullah, MAgr dan Bapak Rezky Khrisrachmansyah, SP. MT, yang telah memberikan arahan dan masukan sehingga skripsi ini dapat diperbaiki menjadi lebih baik. Penulis menghaturkan banyak terima kasih kepada staf dari Dinas Pekerjaan Umum dan Penataan Ruang, Perumahan, dan Kawasan Pemukiman, khususnya staf Bidang Pertamanan dan Pemakaman serta kepada staf dari Dinas Kepemudaan, Olahraga, Kebudayaan, dan Pariwisata Kota Tasikmalaya yang telah banyak membantu penulis dalam memperoleh informasi dan data.

Penghargaan penulis sampaikan kepada Bapak Tommi Kosman, Mama Eli Yulia, Teh Siti Rahmi Nur Utami, Teh Dita Nur Ilhami, dan keluarga besar atas dukungan dan doa yang tiada henti. Dukungan dan bantuan juga datang dari teman seperjuangan Soraya, Hafsah, Puji, Rizza, Ajeng, Annisa, Anggi, Lulu, Nurul, Dewi, dan teman-teman ARL 51 lainnya. Dukungan tak henti selama masa penelitian juga datang dari Anggi, Puti, Manda, Fau, Tami, Faje, Bibin, dan sahabat Wisma Afidi lainnya. Dukungan dan doa juga selalu diberikan oleh Puti, Ajeng, Yurid, Asep, Anton, Hamzah, Novi, Alin, Syahrul, Arin, $A$ Andri, $A$ Rio, dan teman-teman HIMALAYA IPB lainnya. Tak lupa sahabat halaqoh yang selalu bertukar doa dan dukungan Mbak Astrini, Listi, Ajeng, Uti, Mira, Septi, Riyani, Dinda, Selvi, dan Betri. Penulis sangat bersyukur atas dukungan dan keberadaan mereka semua.

Tiada yang sempurna dalam dunia ini, begitu pun dengan skripsi penulis. Penulis menerima kritik dan saran untuk menjadi pembelajaran ke depannya. Penulis juga berharap skirpsi ini dapat memberi manfaat seluasluasnya khususnya bagi pembaca.

Bogor, Oktober 2018

Intan Nur Fathonah 


\section{DAFTAR ISI}

DAFTAR TABEL

DAFTAR GAMBAR viii

DAFTAR LAMPIRAN $\quad \mathrm{x}$

PENDAHULUAN 1

Latar Belakang 1

Tujuan Penelitian 2

Batasan Penelitian 2

Manfaat Penelitian 2

$\begin{array}{ll}- \text { Kerangka Pikir } & 2\end{array}$

TINJAUAN PUSTAKA

Ruang Terbuka Hijau 4

Fungsi Ekologis RTH sebagai Ameliorasi Iklim Mikro 5

Kenyamanan Thermal 6

$\begin{array}{ll}\text { Estetika } & 7\end{array}$

$\begin{array}{ll}\text { Scenic Beauty Estimation (SBE) } & 7\end{array}$

Persepsi dan Preferensi 8

METODOLOGI $\quad 9$

Lokasi dan Waktu Penelitian 9

¿Alat dan Bahan 9

$\begin{array}{lr}\text { Metode Penelitian } & 10\end{array}$

HASIL DAN PEMBAHASAN 18

Kondisi Umum 18

Identifikasi Jenis dan Fungsi Tanaman 22

Evaluasi Fungsi Ekologis $\quad 26$

Evaluasi Kualitas Estetika Lanskap $\quad 64$

Persepsi dan Preferensi Responden $\quad 70$

Rekomendasi Perbaikan Penataan Tanaman Ruang Terbuka Hijau 75

SIMPULAN DAN SARAN $\quad 82$

$\begin{array}{ll}\text { Simpulan } & 82\end{array}$

$\begin{array}{lr}\text { Saran } & 82\end{array}$

DAFTAR PUSTAKA $\quad 83$

DAFTAR TABEL

1. Klasifikasi RTH berdasarkan kepemilikan RTH 4

2. Bentuk dan jenis data 11

3. Kriteria fungsi penanaman pohon 11

4. Kriteria penilaian fungsi ekologis $\quad 15$

5. Baku mutu tingkat kebisingan 16

6. Jenis dan fungsi pohon di Alun-alun 23 
7. Jenis dan fungsi pohon di Taman Kota

8. Jenis dan fungsi pohon di Kompleks Olahraga Wiradadaha 24

9. Penilaian aspek fungsi modifikasi suhu di Alun-alun 27

10. Hasil pengukuran suhu udara di Alun-alun 27

11. Penilaian aspek fungsi modifikasi suhu di Taman Kota 29

12. Hasil pengukuran suhu udara di Taman Kota 31

13. Penilaian aspek fungsi modifikasi suhu di Kompleks Olahraga Wiradadaha

14. Hasil pengukuran suhu udara di Kompleks Olahraga Wiradadaha 34

15. Persentase penilaian tanaman fungsi modifikasi suhu 34

16. Rata-rata suhu udara Alun-alun, Taman Kota, dan Kompleks Olahraga Wiradadaha

17. Penilaian aspek fungsi kontrol kelembaban udara di Alun-alun 36

18. Hasil pengukuran kelembaban udara di Alun-Alun 38

19. Penilaian aspek fungsi kontrol kelembaban udara di Taman Kota 38

20. Hasil pengukuran kelembaban udara di Taman Kota 40

21. Penilaian aspek fungsi kontrol kelembaban udara di Kompleks Olahraga Wiradadaha

22. Hasil pengukuran kelembaban udara di Kompleks Olahraga Wiradadaha

23. Persentase penilaian tanaman fungsi kontrol kelembaban udara 44

24. Rata-rata kelembaban udara Alun-alun, Taman Kota, dan Kompleks Olahraga Wiradadaha

25. Penilaian aspek fungsi penahan angin di Alun-alun

26. Penilaian aspek fungsi penahan angin di Taman Kota

27. Penilaian aspek fungsi penahan angin di Kompleks Olahraga Wiradadaha

28. Persentase penilaian tanaman fungsi penahan angin

29. Penilaian aspek fungsi peredam kebisingan di Alun-alun 53

30. Hasil pengukuran kebisingan di Alun-alun $\quad 54$

31. Penilaian aspek fungsi peredam kebisingan di Taman Kota $\quad 56$

32. Hasil pengukuran kebisingan di Taman Kota 58

33. Penilaian aspek fungsi peredam kebisingan di Kompleks Olahraga Wiradadaha

34. Hasil pengukuran kebisingan di Kompleks Olahraga Wiradadaha 61

35. Persentase penilaian tanaman fungsi peredam kebisingan 62

36. Rata-rata kebisingan Alun-alun, Taman Kota, dan Kompleks Olahraga Wiradadaha

37. Penilaian THI di Alun-alun, Taman Kota, dan Kompleks Olahraga Wiradadaha

\section{DAFTAR GAMBAR}

1. Kerangka pikir penelitian

2. Lokasi tapak studi

3. Tahapan penelitian

4. Persebaran segmen dan titik pengukuran di Alun-alun 
5. Persebaran segmen dan titik pengukuran di Taman Kota

6. Persebaran segmen dan titik pengukuran di Kompleks Olahraga Wiradadaha

7. Kondisi eksisting Alun-alun: (a) gerbang, (b) WC umum, (c) jogging track, dan (d) pedagang

8. Tugu Alun-alun: (a) patung Mak Eroh dan Abdul Rozak, (b) relief-relief penggambaran Tasikmalaya

9. Kondisi eksisting Taman Kota: (a) signage, (b) tempat bermain anak, (c) gazebo, dan (d) tugu peresmian Kota Tasikmalaya

10. Tugu peresmian Kota Tasikmalaya: (a) bentuk tugu dan (b) prasasti peresmian Kota Tasikmalaya

11. Kondisi eksisting Kompleks Olahraga Wiradadaha: (a) lapangan basket, (b) tempat bermain anak, (c) Taman Dadaha, dan (d) gedung kesenian

22

12. Penilaian fungsi modifikasi suhu di Alun-alun 28

13. Penilaian fungsi modifikasi suhu di Taman Kota 30

14. Penilaian fungsi modifikasi suhu di Kompleks Olahraga

Wiradadaha

15. Persentase persepsi responden tentang suhu udara di (a) Alunalun, (b) Taman Kota, dan (c) Kompleks Olahraga Wiradadaha 35

16. Penilaian fungsi kontrol kelembaban di Alun-alun

17. Penilaian fungsi kontrol kelembaban di Taman Kota

18. Penilaian fungsi kontrol kelembaban di Kompleks Olahraga Wiradadaha

19. Persentase persepsi responden tentang kelembaban udara di (a) Alun-alun, (b) Taman Kota, dan (c) Kompleks Olahraga Wiradadaha

20. Penilaian fungsi penahan angin di Alun-alun

21. Penilaian fungsi penahan angin di Taman Kota

22. Penilaian fungsi penahan angin di Kompleks Olahraga Wiradadaha

23. Persentase persepsi responden tentang kecepatan angin di (a) Alun-alun, (b) Taman Kota, dan (c) Kompleks Olahraga Wiradadaha

24. Penilaian fungsi peredam kebisingan di Alun-alun

25. Penilaian fungsi peredam kebisingan di Taman Kota

26. Penilaian fungsi peredam kebisingan di Kompleks Olahraga Wiradadaha

27. Persentase persepsi responden tentang kebisingan di (a) Alun-alun, (b) Taman Kota, dan (c) Kompleks Olahraga Wiradadaha

28. Grafik nilai SBE pada Alun-alun

29. Sebaran foto lanskap Alun-alun dan klasifikasinya

30. (a) Lanskap 4 (nilai SBE tertinggi) dan (b) Lanskap 13 (nilai SBE terendah)

31. Grafik nilai SBE pada Taman Kota

32. Sebaran foto lanskap Taman Kota dan klasifikasinya

33. (a) Lanskap 1 (nilai SBE tertinggi) dan (b) Lanskap 11 (nilai SBE terendah) 
34. Grafik nilai SBE pada Kompleks Olahraga Wiradadaha

35. Sebaran foto lanskap Kompleks Olahraga Wiradadaha dan klasifikasinya

36. (a) Lanskap 18 (nilai SBE tertinggi) dan (b) Lanskap 21 (nilai SBE terendah)

37. Persentase jenis kelamin responden di (a) Alun-alun, (b) Taman Kota, dan (c) Kompleks Olahraga Wiradadaha

38. Persentase daerah asal responden di (a) Alun-alun, (b) Taman Kota, dan (c) Kompleks Olahraga Wiradadaha

39. Persentase usia responden di (a) Alun-alun, (b) Taman Kota, dan (c) Kompleks Olahraga Wiradadaha

40. Persentase pekerjaan responden di (a) Alun-alun, (b) Taman Kota, dan (c) Kompleks Olahraga Wiradadaha

41. Persentase pendidikan terakhir responden di (a) Alun-alun, (b) Taman Kota, dan (c) Kompleks Olahraga Wiradadaha

42. Persentase tujuan kunjungan responden di (a) Alun-alun, (b) Taman Kota, dan (c) Kompleks Olahraga Wiradadaha

43. Persepsi keindahan pemandangan oleh responden di (a) Alun-alun, (b) Taman Kota, dan (c) Kompleks Olahraga Wiradadaha

44. Persepsi keindahan penataan tanaman oleh responden di (a) Alunalun, (b) Taman Kota, dan (c) Kompleks Olahraga Wiradadaha

45. Persepsi kebersihan oleh responden di (a) Alun-alun, (b) Taman Kota, dan (c) Kompleks Olahraga Wiradadaha

46. Persepsi kepuasan terhadap (a) Alun-alun, (b) Taman Kota, dan

(c) Kompleks Olahraga Wiradadaha

47. Ilustrasi penambahan bangku taman di jalur jogging (a) sebelum dan (b) sesudah

48. Ilustrasi komposisi penataan tanaman peredam kebisingan (a) sebelum dan (b) sesudah

49. Contoh penerapan prinsip desain variasi dan pengulangan dalam penataan tanaman

50. Ilustrasi penataan tanaman di area gerbang (a) sebelum dan (b) sesudah

51. Ilustrasi parklet setelah penambahan pohon peneduh (a) sebelum dan (b) sesudah

52. Ilustrasi komposisi tanaman untuk meredam kebisingan

53. Ilustrasi penataan tanaman di area berumput (a) sebelum dan (b) sesudah

54. Contoh pepohonan dengan bantuk tajuk horizontal

55. Contoh penerapan prinsip desain pengulangan

\section{DAFTAR LAMPIRAN}

1. Contoh penilaian fungsi ekologis tanaman 86

2. Kuesioner pengunjung Alun-alun 90

3. Kuesioner pengunjung Taman Kota 93

4. Kuesioner pengunjung Kompleks Olahraga Wiradadaha 96 
5. Kuesioner Scenic Beauty Estimation 99

6. Foto lanskap Alun-alun 100

7. Foto lanskap Taman Kota 103

8. Foto lanskap Kompleks Olahraga Wiradadaha 106

9. Pemetaan rekomendasi perbaikan penataan tanaman di Alun-alun 107

10. Pemetaan rekomendasi perbaikan penataan tanaman di Taman Kota

11. Pemetaan rekomendasi perbaikan penataan tanaman di Kompleks Olahraga Wiradadaha 


\section{PENDAHULUAN}

\section{Latar Belakang}

Tasikmalaya merupakan salah satu kota yang berada di Provinsi Jawa Barat. Sejak berdiri pada tahun 2001, kota hasil pemekaran dari Kabupaten Tasikmalaya ini terus berkembang yang dapat dilihat dari adanya pemekaran kecamatan pada tahun 2008 dan pertumbuhan penduduk yang mencapai 1.87 persen pada tahun 2017 (Mulyana 2017). Beberapa kecamatan di pusat kota berkembang cukup pesat, memiliki densitas penduduk yang mencapai lebih dari $10.000 \mathrm{jiwa} / \mathrm{km}^{2}$ (BPS Kota Tasikmalaya 2016).

Menurut Perda Kota Tasikmalaya Nomor 9 Tahun 2008 mengenai kondisi umum Kota Tasikmalaya, RTH yang tercatat pada tahun 2005 terdiri dari hutan seluas $16.8 \%$ dan daerah konservasi serta sawah seluas $29.96 \%$ dari total luas kota yang lebih banyak tersebar di area pinggiran kota. Pertumbuhan penduduk mendorong perluasan area perumahan yang mengalami kenaikan sebesar $1.56 \%$ sejak tahun 2005. Kepadatan penduduk dan pergerakan kendaraan akan menekan kualitas lingkungan dan berkontribusi dalam penyebab Urban Heat Island (Effendy, Bey, Santosa, Zain 2006).

Salah satu bentuk penurunan kualitas lingkungan di Kota Tasikmalaya yaitu meningkatnya suhu kota. Suhu kota mengalami kenaikan dari $27.9{ }^{\circ} \mathrm{C}$ pada tahun 2012 menjadi $28.1{ }^{\circ} \mathrm{C}$ pada tahun 2016 (Tim Satker Sanitasi Tasikmalaya 2012; BPS Kota Tasikmalaya 2017). Faktor lain meningkatnya suhu disebabkan oleh kurangnya penanganan dan perbaikan dalam menata tanaman yang ada di sekitar Rota.

RTH publik menjadi alternatif tempat rekreasi alam di kota yang mampu memberikan kenyamanan lingkungan yang jarang dirasakan masyarakat di area kota, khususnya kota yang mengalami fenomena urban heat island. RTH mampu memberikan kenyamanan lingkungan dengan mengameliorasi iklim mikro. Ameliorasi iklim mikro dilakukan dengan memodifikasi suhu, mengontrol kelembaban, mengatur aliran angin, dan meredam kebisingan (Grey dan Deneke 1978). RTH juga perlu memperhatikan keindahan visual lanskapnya. Keindahan visual atau biasa disebut dengan istilah estetika menurut Simonds (1983), merupakan hubungan yang harmonis dari semua elemen atau komponen yang dirasakan. Keindahan visual sebuah RTH dapat menjadi identitas dan memberi kesan yang akan membuat pengunjung kembali berkunjung ke RTH tersebut.

RTH publik berupa taman kota hanya berjumlah tiga taman di Kota Tasikmalaya, yaitu Alun-alun, Taman Kota, dan Kompleks Olahraga Wiradadaha. Ketiga RTH publik ini berlokasi di pusat Kota Tasikmalaya dan keberadaannya sangat penting bagi lingkungan dan masyarakat. Ketiga RTH publik ini sangat terjangkau oleh masyarakat dan menjadi pusat rekreasi. Meski selalu ramai dikunjungi masyarakat, ketiga RTH publik dirasa masih kurang memberikan kenyamanan thermal dan keindahan yang optimal. Kenyamanan thermal dirasa masih kurang khususnya di Alun-alun dan Taman Kota karena kurangnya pepohonan peneduh. Kompleks Olahraga Wiradadaha dinilai belum mampu memberikan keindahan yang membuat pengunjung betah berlama-lama di sana. 
Peningkatan kualitas ketiga RTH publik Kota Tasikmalaya sangat penting dilakukan untuk memberi ruang rekreasi yang lebih nyaman bagi masyarakat kota. Kualitas RTH dapat dilihat dari keoptimalam RTH khususnya dalam fungsi ekologis dan estetika RTH. Untuk mengetahui fungsi ekologis terhadap kenyamanan thermal dan fungsi estetika RTH, maka perlu dilakukan evaluasi terhadap fungsi ekologis dan estetika pada beberapa RTH publik di Kota Tasikmalaya yang terdiri dari Alun-alun, Taman Kota, dan Kompleks Olahraga Wiradadaha.

\section{Tujuan Penelitian}

Penelitian mengenai evaluasi fungsi ekologis dan estetika beberapa RTH publik di Kota Tasikmalaya ini memiliki beberapa tujuan sebagai berikut:

1. Imengidentifikasi jenis dan fungsi tanaman di Alun-alun, Taman Kota, dan Kompleks Olahraga Wiradadaha Tasikmalaya,

2. Tmengevaluasi fungsi ekologis dan estetika RTH Alun-alun, Taman Kota, dan Kompleks Olahraga Wiradadaha Tasikmalaya dengan membandingkan penilaian melalui kriteria tanaman, pengukuran unsur-unsur iklim, dan persepsi masyarakat, dan

3. menyusun rekomendasi perbaikan penataan tanaman RTH Alun-alun, Taman Kota, dan Kompleks Olahraga Wiradadaha Tasikmalaya.

\section{Batasan Penelitian}

Batasan penelitian ini hanya mencakup evaluasi mengenai fungsi ekologis ameliorasi iklim dengan variabel suhu, kelembaban, angin, dan kebisingan. Penelitian ini juga mengevaluasi fungsi estetika. Evaluasi fungsi ekologis dan estetika ini dilakukan di tiga RTH publik Kota Tasikmalaya, yaitu Alun-alun, Taman Kota, dan Kompleks Olahraga Wiradadaha.

\section{Manfaat Penelitian}

Penelitian ini diharapkan dapat memberikan manfaat bagi Pemerintah Kota Tasikmalaya dalam upaya perbaikan penataan tanaman RTH publik agar dapat memberi fungsi ekologis dan estetika yang lebih optimal. Penelitian ini juga dapat menjadi referensi bagi akademisi sehingga ke depannya penelitian ini dapat dikembangkan atau pun diteliti lebih lanjut. Masyarakat diharapkan dapat memperoleh wawasan dari hasil penelitian ini mengenai manfaat dari $\mathrm{RTH}$, di antaranya fungsi ekologis dan estetika RTH.

\section{Kerangka Pikir}

Tasikmalaya merupakan kota yang sedang berkembang dan terus terjadi pertumbuhan penduduk yang mampu menekan kualitas lingkungan. Penurunan kualitas lingkungan terjadi karena kepadatan penduduk dan kendaraan mendorong 
terus dilakukannya pembangunan yang dapat menurunkan daya dukung lingkungan. Keberadaan RTH di kota sangat penting karena dapat memberikan banyak fungsi, beberapa di antaranya adalah fungsi ekologis dan estetika. Penelitian ini dilakukan untuk mengetahui fungsi ekologis dan estetika pada beberapa RTH publik di Kota Tasikmalaya. Penelitian dilakukan dengan mengevaluasi fungsi ekologis, khususnya fungsi ameliorasi iklim, dan estetika RTH. Evaluasi fungsi ekologis dilakukan dengan menilai tanaman yang ada serta menganalisis fungsi ameliorasi iklim dengan variabel suhu, kelembaban udara, angin, dan kebisingan di masing-masing RTH. Persepsi dan prefensi pengguna RTH perlu diketahui sebagai alat pembanding penilaian dan pemberi masukan dalam penyusunan rekomendasi perbaikan penataan tanaman RTH. Evaluasi fungsi estetika dilakukan dengan metode Scenic Beauty Estimation dan persepsi serta preferensi pengguna RTH terhadap kualitas visual/estetika dari RTH. RTH publik yang akan diteliti berupa taman dan kompleks olahraga di Kota Tasikmalaya. Kerangka pikir disusun dalam diagram alur (Gambar 1).

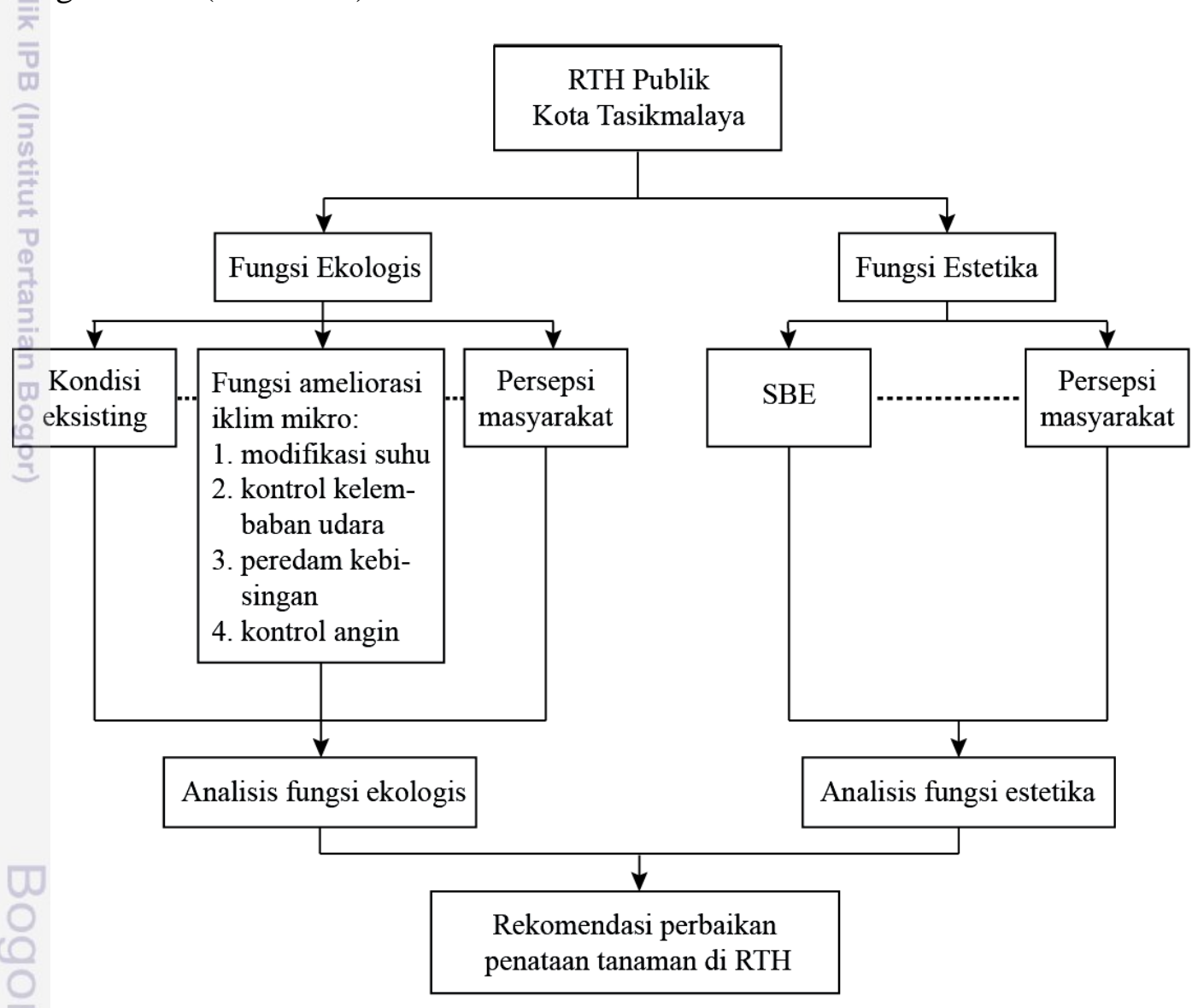

$\longrightarrow$ Alur

...... Keterkaitan

Gambar 1 Kerangka pikir penelitian 


\section{TINJAUAN PUSTAKA}

\section{Ruang Terbuka Hijau}

Ruang Terbuka Hijau atau RTH merupakan area memanjang dan atau mengelompok yang penggunaannya lebih bersifat terbuka, tempat tumbuh tanaman baik yang tumbuh secara alamiah maupun yang sengaja ditanam (Departemen PU 2007). Tujuan penyelenggaraan Ruang Terbuka Hijau (RTH) menurut Departemen PU (2008) berdasarkan Peraturan Menteri Pekerjaan Umum Nomor 5/PRT/M/2008 tentang Pedoman Penyediaan dan Pemanfaatan Ruang Terbuka Hijau di Kawasan Perkotaan adalah:

1. menjaga ketersediaan lahan sebagai kawasan resapan air;

2. menciptakan aspek planologis perkotaan melalui keseimbangan antara Jingkungan alam dan lingkungan binaan yang berguna untuk kepentingan masyarakat; dan

3. - meningkatkan keserasian lingkungan perkotaan sebagai sarana pengaman lingkungan perkotaan yang aman, nyaman, segar, indah dan bersih.

RTH merupakan bagian dari ruang terbuka wilayah perkotaan yang diisi oleh tanaman yang tumbuh secara alami maupun ditanam secara sengaja untuk mendukung manfaat yang dapat dirasakan langsung oleh masyarakat sekitarnya maupun manfaat yang akan terasa dalam jangka waktu yang panjang untuk ke depannya. Manfaat yang dapat dirasakan langsung biasanya bersifat tangible seperti keindahan visual, sedangkan manfaat yang tidak dapat langsung dirasakan biasanya bersifat intangible seperti pembersih udara yang efektif, pemeliharaan dan kesediaan air tanah, serta pelestarian fungsi lingkungan (konservasi keanekaragaman hayati).

Menurut Departemen PU (2008) RTH terbagi menjadi beberapa jenis sesuai dengan tipologinya. Secara fisik, RTH terbagi menjadi RTH alami dan RTH binaan. RTH alami biasanya berupa habitat liar alami, kawasan lindung, dan taman nasional, sedangkan RTH binaan biasanya berupa taman, lapangan olahraga, pemakaman, dan jalur hijau jalan. Tipologi RTH berdasarkan fungsinya dibagi menjadi fungsi ekologis, sosial budaya, estetika, dan ekonomi. Secara struktur ruang, RTH berstruktur ekologis memiliki pola mengelompok, memanjang, dan tersebar sedangkan RTH berstruktur planologis memiliki pola yang mengikuti hirarki dan struktur ruang perkotaan. Berdasarkan kepemilikannya (Tabel 1), RTH terbagi menjadi RTH publik dan RTH privat.

Tabel 1 Klasifikasi RTH berdasarkan kepemilikan RTH

\begin{tabular}{|c|c|c|c|c|}
\hline No & & Jenis & $\begin{array}{c}\text { RTH } \\
\text { Publik }\end{array}$ & $\begin{array}{c}\text { RTH } \\
\text { Privat }\end{array}$ \\
\hline \multicolumn{5}{|c|}{$1 \quad$ RTH Pekarangan } \\
\hline & & a. Pekarangan rumah tinggal & & $\sqrt{ }$ \\
\hline & & $\begin{array}{l}\text { b. Halaman perkantoran, pertokoan, dan } \\
\text { tempat usaha }\end{array}$ & & $\sqrt{ }$ \\
\hline & (3) & c. Taman atap bangunan & & $\sqrt{ }$ \\
\hline
\end{tabular}


Tabel 1 Klasifikasi RTH berdasarkan kepemilikan RTH (lanjutan)

\begin{tabular}{|c|c|c|c|}
\hline No & Jenis & $\begin{array}{c}\text { RTH } \\
\text { Publik }\end{array}$ & $\begin{array}{l}\text { RTH } \\
\text { Privat }\end{array}$ \\
\hline 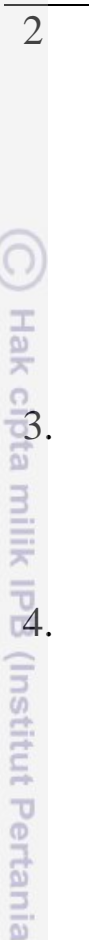 & $\begin{array}{l}\text { RTH Taman dan Hutan Kota } \\
\text { a. Taman RT } \\
\text { b. Taman RW } \\
\text { c. Taman kelurahan } \\
\text { d. Taman kecamatan } \\
\text { e. Taman kota } \\
\text { f. Hutan kota } \\
\text { g. Sabuk hijau } \\
\text { RTH Jalur Hijau Jalan } \\
\text { a. Pulau jalan dan median jalan } \\
\text { b. Jalur pejalan kaki } \\
\text { c. Ruang di bawah jalan layang } \\
\text { RTH Fungsi Tertentu } \\
\text { a. RTH sempadan rel kereta api } \\
\text { b. Jalur hijau jaringan listrik tegangan tinggi } \\
\text { c. RTH sempadan sungai } \\
\text { d. RTH sempadan pantai } \\
\text { e. RTH pengamanan sumber air baku/mata air } \\
\text { f. Pemakaman }\end{array}$ & $\begin{array}{l}\sqrt{ } \\
\sqrt{ } \\
\sqrt{ } \\
\sqrt{ } \\
\sqrt{ } \\
\sqrt{ } \\
\sqrt{ }\end{array}$ & $\begin{array}{l}\sqrt{ } \\
\sqrt{ } \\
\sqrt{ } \\
\sqrt{ }\end{array}$ \\
\hline
\end{tabular}

Sumber: Departemen PU 2008

\section{Fungsi Ekologis RTH sebagai Ameliorasi Iklim Mikro}

Fungsi utama RTH adalah fungsi ekologis yang dapat mempertahankan ekosistem dengan menyeimbangkan kondisi lingkungan. Fungsi ekologis merupakan fungsi yang sering terlupakan namun sangat diperlukan terutama di kawasan perkotaan. Menurut Departemen PU (2008), fungsi ekologis RTH di antaranya 1) memberi jaminan pengadaan RTH menjadi bagian dari sistem sirkulasi udara; 2) pengatur iklim mikro agar sistem sirkulasi udara dan air secara alami dapat berlangsung lancar; 3) sebagai peneduh; 4) produsen oksigen; 5) penyerap air hujan; 6) penyedia habitat satwa; 7) penyerap polutan media udara, air, dan tanah serta; dan 8) penahan angin.

Pengatur iklim mikro atau ameliorasi iklim mikro merupakan salah satu fungsi ekologis RTH. RTH sebagai ameliorasi iklim mikro dapat menciptakan zona nyaman dengan mengatur empat elemen utama dalam ameliorasi iklim sesuai dengan komposisinya. Empat elemen utama yang dimiliki ameliorasi iklim adalah radiasi matahari, suhu udara, kelembaban udara, dan pergerakan angin (Grey dan Deneke 1978). RTH dapat mengatur keempat elemen iklim ameliorasi iklim dengan penggunaan tanaman yang sesuai di ruang terbuka yang ada.

Suhu merupakan salah satu elemen yang sangat mempengaruhi kenyamanan lingkungan. Menurut Keputusan Menteri Kesehatan No.829 / Menkes / SK / VII / 1999, suhu udara yang nyaman bagi lingkungan permukiman sehat yaitu sekitar 18$30{ }^{\circ} \mathrm{C}$. Menurut Laurie (1986) dalam Nurnovita (2011), iklim ideal bagi manusia 
adalah udara yang bersih dengan suhu antara 27-28 ${ }^{\circ} \mathrm{C}$. Tanaman dapat mengontrol/mengameliorasi suhu dengan mengintersepsi, merefleksi, mengabsorbsi, dan mentransmitkan radiasi matahari. Keefektivitasan tanaman dalam mengkontrol radiasi matahari berbeda-beda. Menurut Grey dan Daneke (1978), efektivitas tanaman dalam menangkap radiasi matahari tergantung pada kepadatan daun, bentuk daun, dan pola percabangan. Tanaman bertajuk lebar dan memiliki ketinggian kanopi lebih dari 2 meter juga dapat mengahalangi radiasi matahari dan menurunkan suhu lingkungan (DPU 1996; Simonds 1983). Menurut Femy (2014), bentuk tajuk bulat dan bulat terbuka efektif menurunkan suhu sebesar $2{ }^{\circ} \mathrm{C}$ dan meningkatkan kelembaban sebesar $5 \%$.

Kelembaban udara merupakan kandungan uap air di udara. Kelembaban air sangat dipengaruhi oleh suhu udara, dimana semakin tinggi suhu udara maka kelembaban udara menjadi rendah karena kapasitas untuk menampung uap air pun rendah. Kelembaban yang ideal menurut Laurie (1986) adalah sekitar 40-75\%. Kelembaban di bawah tajuk lebih tinggi dan evaporasi lebih rendah sehingga suhu menjadi lebih rendah dari lingkungan sekelilingnya ketika siang hari dan hangat ketika malam hari (Grey dan Daneke 1978). Kelembaban yang mendekati kenyamanan terdapat pada bagian pohon dengan kerapatan daun yang rendah (Bianpoen et al. 1989).

Angin merupakan salah satu elemen dalam ameliorasi iklim. Ketika kondisi di luar ruangan tidak nyaman pada siang hari karena suhu yang tinggi, angin dapat memberi kenyamanan dengan meningkatkan penguapan pendinginan (Grey dan Daneke 1978). Di sisi lain angin juga memiliki sifat merusak bila kecepatannya tinggi. Tanaman seperti pohon dan semak dapat mengontrol angin dengan menghalangi, mengarahkan, membelokan, dan menyaring angin. Tanaman dapat mengurangi kecepatan angin sebesar 75-85\%. Kemudian menurut Carpenter, Walker, dan Lamphear (1975), komposisi tanaman yang berbeda dapat mengurangi kecepatan angin sekitar 40-50\%. Efeknya bervariasi tergantung ukuran spesies, bentuk daun, kepadatan dan retensi daun, dan posisi penempatan tanaman (Grey dan Daneke 1978). Tanaman yang menghalangi angin dapat menciptakan area proteksi yang baik yang jaraknya 10-20 kali dari ketinggian tanaman pelindung.

\section{Kenyamanan Thermal}

Kenyaman thermal merupakan kenyamanan yang diukur dari panas yang dirasakan oleh manusia. Kenyamanan thermal telah diteliti oleh para ahli, salah satunya yaitu secara kuantitatif dengan metode Thermal Humidity Index (THI). THI merupakan suatu indeks untuk menetapkan efek kondisi panas pada kenyamanan manusia dengan menghubungkan antara suhu dan kelembaban udara, yang secara empiris dirumuskan Nieuwolt pada tahun 1975. THI hanya mengukur kenyamanan dengan variabel suhu dan kelembaban tanpa mempertimbangkan unsur iklim lain atau faktor lain yang berkaitan dengan manusia sebagai subjek yang merasakan kenyamanan tersebut (Zahra, Sitawati, dan Suryanto 2014).

Dalam penelitiannya, Mulyana, Laras, dan Budi (2003) menyatakan bahwa indeks kenyamanan yang paling sesuai berada pada kisarah THI 20-26 ${ }^{\circ} \mathrm{C}$. Emmanuel (2005) menyatakan bahwa $100 \%$ populasi manusia merasa nyaman pada THI antara 21-24 ${ }^{\circ} \mathrm{C}$. Pada THI sebesar $25-27{ }^{\circ} \mathrm{C}$, 50\% populasi manusia 
menyatakan nyaman sedangkan pada $\mathrm{THI}>27{ }^{\circ} \mathrm{C}, 100 \%$ populasi manusia menyatakan tidak nyaman.

RTH merupakan elemen di kawasan perkotaan yang dapat meningkatkan nilai kenyamanan lingkungan perkotaan. Menurut Effendi, Bey, Zain, dan Santosa (2006), laju pengurangan RTH dapat menyebabkan peningkatan suhu udara dan sebaliknya. Penelitian Femy (2014) juga menyatakan bahwa semakin luas RTH maka suhu akan semakin rendah. RTH yang berkurang akan otomatis menurunkan pula jumlah tanaman yang berfungsi untuk menyerap radiasi matahari sehingga peningkatan suhu udara akan terus terjadi.

Peningkatan suhu udara akan meningkatan nilai THI yang menunjukkan penurunan kenyamanan lingkungan. Upaya pengkajian fungsi ekologis dalam mengameliorasi iklim oleh RTH dapat dilihat dari perubahan yang nyata terhadap THI. Menurunnya nilai THI dapat menjadi indikasi bahwa telah meningkatnya kenyamanan kota.

\section{Estetika}

Estetika merupakan hubungan yang harmonis dari semua elemen atau komponen yang dirasakan (Simonds 1983). Estetika dapat memberi kenyamanan dengan memperlihatkan kualitas visual yang baik dari suatu lanskap, hasil dari kombinasi elemen lanskap yang membentuk suatu kesatuan. Elemen lanskap terdiri softscape (elemen lunak) dan hardscape (elemen keras). Contoh softscape yaitu vegetasi dan air sedangkan contoh hardscape yaitu bangunan dan perkerasan.

Elemen-elemen lanskap didesain dengan enam prinsip desain menurut Whiting dan De Jong (2012), di antaranya unity (kesatuan), balance (keseimbangan), simplicity dan variety (simpel dan variasi), emphasis (kontras), dan sequence (irama/pengulangan). Kualitas visual dari elemen-elemen desain seperti garis, bentuk, tekstur, dan warna juga perlu diperhatikan sehingga dapat memberi emosi dan persepsi yang baik kepada pengunjung (Hansen 2016).

Estetika dapat menjadi indikator kualitas lingkungan dan pembentuk karakter serta identitas suatu tempat. Berbagai keunggulan yang muncul karena adanya nilai estetika dalam suatu lanskap membuat estetika menjadi salah satu nilai yang penting untuk dimiliki suatu lanskap dan perlu dilestarikan. Kualitas estetika suatu lanskap dapat memberi kepuasan kepada seseorang secara langsung dan dapat mempengaruhi perilaku seseorang secara tidak langsung (Nassar 1988). Kepuasan seseorang terhadap visual suatu lanskap dapat meningkatkan kemungkinan ia lebih sering berkunjung ke lanskap tersebut karena ia merasa nyaman dan tidak bosan untuk berada di sana. Perilaku seseorang dapat dipengaruhi oleh kualitas estetika lanskap karena pada dasarnya manusia menyukai keindahan sehingga seseorang yang menilai lingkungannya indah akan berusaha menjaga keindahan itu tetap ada.

\section{Scenic Beauty Estimation (SBE)}

Kualitas visual dari suatu lanskap dapat diukur oleh penilaian manusia. Visual suatu lanskap sulit untuk dinilai secara objektif dan bersifat kualitatif. Estetika pun dinilai oleh manusia secara subjektif karena manusia memiliki standar yang 
berbeda terhadap nilai estetika. Menurut Daniel dan Boster (1976), penilaian secara kualitatif tersebut dapat ditransformasikan menjadi nilai kuantitatif.

Scenic Beauty Estimation (SBE) merupakan suatu metode untuk dapat menilai keindahan suatu lanskap dari objek-objek atau sudut lanskap yang disukai. Penilaian dilakukan dengan menggunakan kuesioner yang diisi berdasarkan preferensi responden terhadap objek-objek lanskap yang diperlihatkan melalui foto, responden di sini lebih mengarah kepada publik yang memiliki ketertarikan atau pengetahuan yang lebih mengenai objek penilaian. Penerapan metode SBE dilakukan dalam tiga langkah utama, yaitu pengambilan foto lanskap, presentasi slide foto, dan analisis data (Daniel dan Boster 1976). Pengambilan foto lanskap dilakukan dengan posisi setinggi mata, objek tidak terhalang benda lain, dan merupakan vintage point. Foto yang telah difoto kemudian dipresentasikan kepada responden dengan slide yang diperlihatkan selama durasi masing-masing \pm 10 detik (Hidayat 2009).

Metode SBE mengukur preferensi masyarakat dengan penilaian memalui sistem rating dengan skala 1-10 terhadap foto lanskap, semakin tinggi nilainya maka semaik baik kualitas dari lanskap. Menurut Kaplan (1988) penilaian manusia terhadap pemandangan melalui foto sama baiknya dengan menilai pemandangan secara langsung. Pengelompok hasil penilaian lanskap dilakukan dengan menggunakan standar oleh Daniel dan Boster (1976) dalam Mahardi (2013), yaitu kualitas estetika rendah memiliki nilai SBE $<-20$, kualitas estetika sedang apabila memiliki nilai SBE antara -20 sampai 20, dan kualitas estetika tinggi apabila nilai SBE $>20$. Pada penilitian Hidayat (2009), konfigurasi tanaman dengan efek visual bayangan pepohonan dan secara struktural memberikan ruang yang nyaman dan teduh mendapat nilai SBE yang tinggi. Lanskap yang memiliki pola penanaman pohon rapat dan padat daunnya serta menimbulkan kesan lembab dan gelap mendapat nilai SBE rendah.

\section{Persepsi dan Preferensi}

Persepsi merupakan stimulus yang diindera oleh individu, diorganisasikan kemudian diinterpretasikan sehingga individu menyadari dan mengerti tentang apa yang diindera (Uma 2015), maka dari itu persepsi manusia pasti berbeda-beda. Eckbo (1964) berpendapat bahwa persepsi dipengaruhi oleh latar belakang intelektual dan pengalaman emosional, pergaulan dan sikap seseorang. Semakin intelek dan banyak pengalaman emosional yang dimiliki seseorang akan semakin dalam persepsi seseorang terhadap suatu objek.

Preferensi merupakan kecenderungan seseorang untuk memilih suatu pilihan yang dipengaruhi oleh banyak faktor. Menurut Abello dan Bernaldez (1986) faktorfaktor yang mempengaruhi preferensi masyarakat antara lain usia, jenis kelamin, tingkat sosial, tingkat pendidikan dan budaya. Preferensi juga dapat disebabkan rasa keterkaitan seseorang terhadap suatu tempat karena lamanya ia tinggal di tempat tersebut.

Persepsi dan preferensi pengunjung sangat berpengaruh dalam penggunaan suatu RTH. Persepsi dan preferensi pengunjung terkait dengan sikap dan perilaku dalam berinteraksi dengan lingkungan dan dapat memengaruhi rasa seseorang pada 
suatu lanskap (Kessel et al. 2009 dalam Barrera et al. 2016; Syahadat et al. 2015 dalam Mariski 2017).

\section{METODOLOGI}

\section{Lokasi dan Waktu Penelitian}

Penelitian dilaksanakan selama 8 bulan pada beberapa RTH publik di Kota Tasikmalaya, di antaranya Alun-Alun, Taman Kota, dan Kompleks Olahraga Wiradadaha (Gambar 2). Alun-Alun berada di Jalan RAA Wiratanuningrat yang berada di Kecamatan Tawang. Taman Kota berada di Jalan H.Z. Mustofa dan Kompleks Olahraga Wiradadaha berada di Jalan Wiradadaha, keduanya termasuk ke dalam wilayah Kecamatan Cihideung.

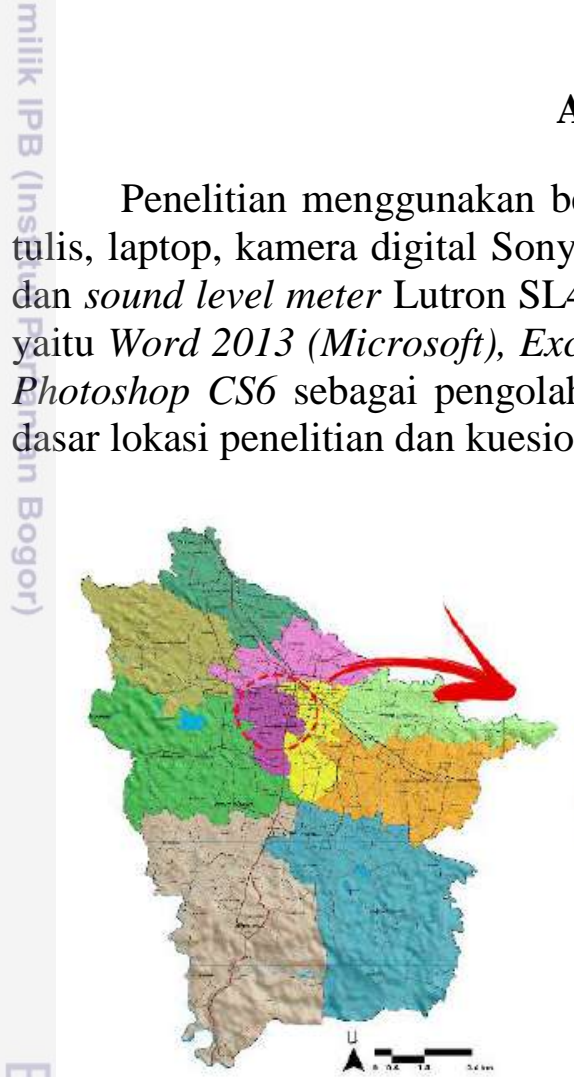

\section{Alat dan Bahan}

Penelitian menggunakan beberapa peralatan antara lain: buku catatan, alat tulis, laptop, kamera digital Sony DSC-W310, thermoghygrometer digital THD8, dan sound level meter Lutron SL4012. Beberapa perangkat lunak juga digunakan, yaitu Word 2013 (Microsoft), Excel 2013 (Microsoft), AutoCAD 2013, dan Adobe Photoshop CS6 sebagai pengolah data. Bahan yang digunakan antara lain: peta dasar lokasi penelitian dan kuesioner.

(a) Kota Tasikmalaya

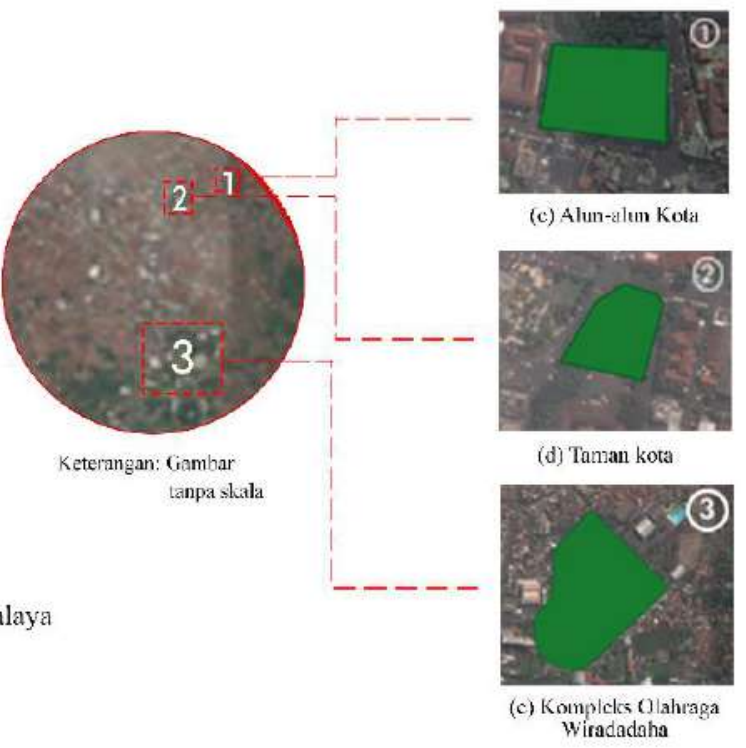

Gambar 2 Lokasi tapak studi

Sumber: Peta Tematik Indonesia, GoogleMaps 


\section{Metode Penelitian}

Metode yang dilakukan pada penelitian ini yaitu kajian terhadap aspek fungsi ekologis dan estetika pada beberapa RTH yang dilakukan dalam beberapa tahapan kerja meliputi tahapan persiapan, inventarisasi, analisis, dan sintesis dengan mengasilkan rekomendasi penataan tanaman (Gambar 3). Penelitian ini mengacu pada penelitian Mahardi (2013) dengan beberapa modifikasi.

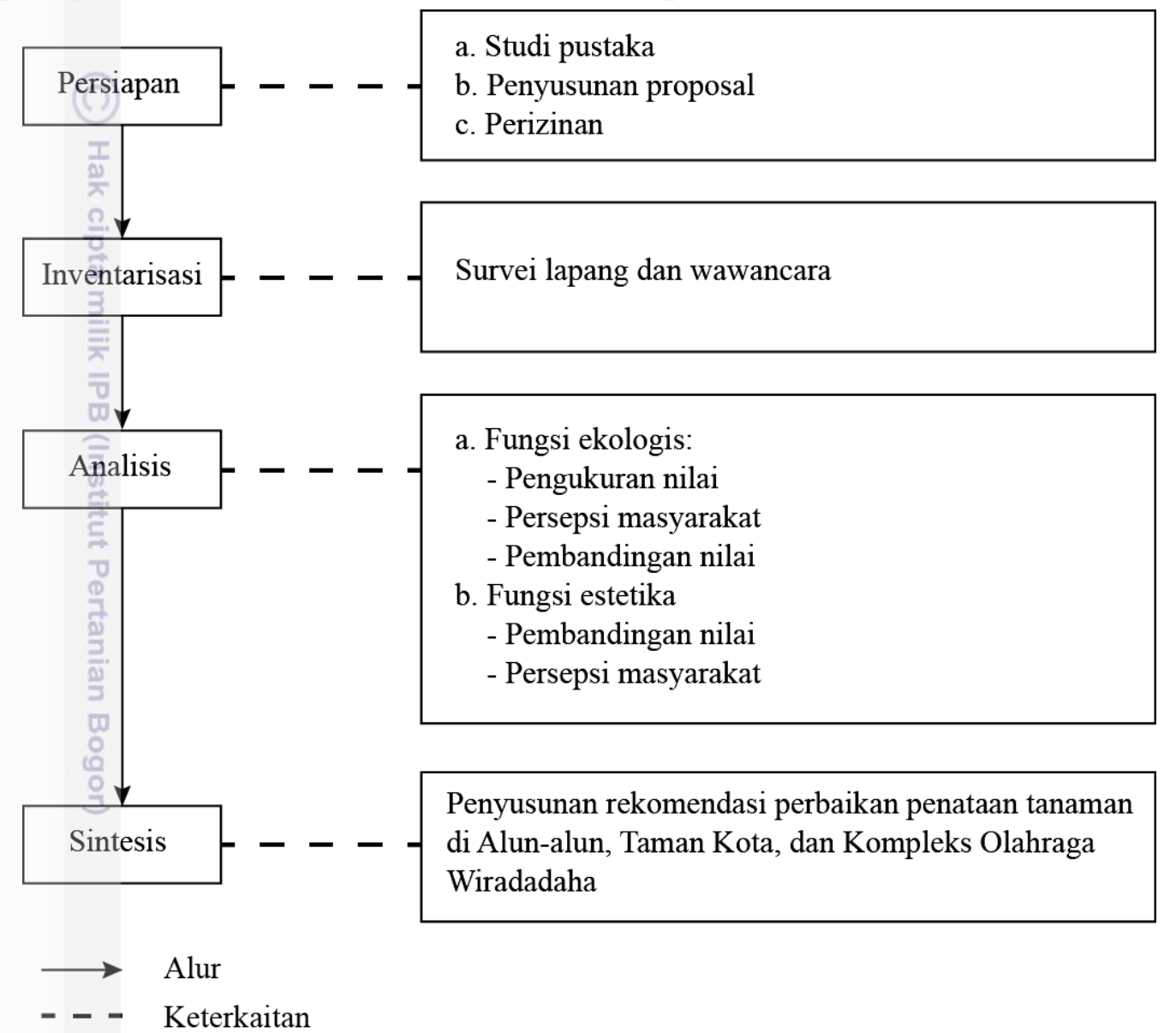

\section{Persiapan}

Persiapan merupakan tahap awal dalam penelitian. Tahapan persiapan dilakukan dengan melakukan studi pustaka untuk mencari referensi dan pengumpulan data sekunder. Penyusunan proposal penelitian juga dilakukan pada tahap ini. Pengurusan perizinan penelitian juga dilakukan pada tahapan persiapan sehingga penelitian dapat segera dilaksanakan.

\section{Inventarisasi}

Inventarisasi adalah kegiatan pengumpulan data dan informasi terkait tapak penelitian. Data yang diperoleh pada tahap ini yaitu data primer dan data sekunder. Data primer diperoleh dari hasil survei lapang. Survei lapang dilakukan dengan pengamatan secara langsung di tapak, pengambilan dokumentasi, wawancara kepada pihak yang terkait, dan wawancara dengan kuesioner kepada responden. Data sekunder diperoleh dari hasil pencarian data ke dinas terkait dan studi pustaka. 
Jenis data yang dibutuhkan mencakup data letak geografis, tanaman, iklim mikro, tingkat kebisingan, dan persepsi masyarakat (Tabel 2). Data iklim mikro diperoleh dengan pengukuran unsur suhu, kelembaban, dan kebisingan di tapak dan untuk dianalisis sebagai pembanding terhadap penilaian tanaman. Pengambilan gambar juga dilakukan pada setiap RTH untuk dokumentasi dan bahan kelengkapan kuesioner. Wawancara dengan panduan kuesioner dilakukan dua kali, kepada pengunjung RTH untuk mengetahui peresepsi dan preferensi masyarakat mengenai kondisi dan kenyamanan lingkungan RTH serta kepada responden khusus yang memiliki pemahaman lebih tentang ilmu arsitektur lanskap untuk menilai kualitas visual RTH.

Tabel 2 Bentuk dan jenis data

\begin{tabular}{|c|c|c|c|c|}
\hline No & Jenis Data & Parameter & Bentuk Data & Sumber Data \\
\hline 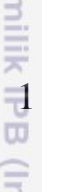 & $\begin{array}{l}\text { Letak } \\
\text { Geografis }\end{array}$ & $\begin{array}{l}\text { Batas wilayah } \\
\text { Luas wilayah } \\
\text { Peta wilayah }\end{array}$ & $\begin{array}{l}\text { Spasial - } \\
\text { kuantitatif }\end{array}$ & $\begin{array}{l}\text { Dinas PUPR, Bidang } \\
\text { Pertamanan dan Pemakaman } \\
\text { Kota Tasikmalaya }\end{array}$ \\
\hline 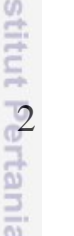 & Tanaman & $\begin{array}{l}\text { Jumlah } \\
\text { tanaman } \\
\text { Jenis tanaman } \\
\text { Fungsi tanaman }\end{array}$ & $\begin{array}{l}\text { Kualitatif-- } \\
\text { kuantitatif }\end{array}$ & Survei lapang \\
\hline $\begin{array}{l}5 \\
0 \\
3 \\
0 \\
0 \\
3\end{array}$ & Iklim mikro & $\begin{array}{l}\text { Suhu udara } \\
\text { Kelembaban } \\
\text { udara }\end{array}$ & Kuantitatif & $\begin{array}{l}\text { Survei lapang } \\
\text { (thermohygrometer) }\end{array}$ \\
\hline 4 & Kebisingan & $\begin{array}{l}\text { Baku mutu } \\
\text { kebisingan }\end{array}$ & Kuantitatif & $\begin{array}{l}\text { Survei lapang (sound level } \\
\text { meter) }\end{array}$ \\
\hline 5 & $\begin{array}{l}\text { Persepsi dan } \\
\text { preferensi }\end{array}$ & $\begin{array}{l}\text { Kenyamanan } \\
\text { Estetika }\end{array}$ & Kualitatif & Survei lapang (kuesioner) \\
\hline
\end{tabular}

a. Identifikasi Jenis dan Fungsi Tanaman

Identifikasi jenis tanaman beserta fungsi penanamannya dilakukan khusus pada pepohonan karena pohon merupakan tanaman yang paling berpengaruh pada kondisi iklim mikro di tapak. Penentuan fungsi penanaman pohon dilakukan berdasarkan Tabel 3. Jumlah jenis dan total individu pepohonan juga dihitung pada masing-masing RTH. Hasil identifikasi dan penghitungan pepohonan diperlukan dalam proses penilaian RTH.

Tabel 3 Kriteria fungsi penanaman pohon

\begin{tabular}{ll}
\multicolumn{1}{c}{ Fungsi pohon } & \multicolumn{1}{c}{ Kriteria pohon } \\
Peneduh & 1. Ketinggian tajuk lebih dari $2 \mathrm{~m}$ \\
Pengarah & 2. Bentuk tajuk menyebar, bulat, kubah, irregular \\
& 3. Massa daun padat \\
& 1. Tanaman sejenis ditanam berulang \\
\end{tabular}


Tabel 3 Kriteria fungsi penanaman pohon (lanjutan)

\begin{tabular}{ll}
\hline \multicolumn{1}{c}{ Fungsi pohon } & \multicolumn{1}{c}{ Kriteria pohon } \\
\hline Pengarah & 3. Pohon ditanam berbaris \\
Estetika & 1. Bentuk tajuk berskala horizontal (bulat, menyebar, \\
& $\begin{array}{l}\text { menjurai, dan eksotis) } \\
\text { 2. Berbunga }\end{array}$ \\
& 3. Daun berwarna mencolok
\end{tabular}

Sumber: DPU (1996, 2008, 2012), Lestari dan Gunawan (2010), Sukewijaya dan Kohdrata (2015), Simonds (1983)

b. Pengukuran Iklim Mikro (Suhu dan Kelembaban Udara)

Data suhu dan kelembaban udara dibutuhkan sebagai pembanding hasil penilaian fungsi modifikasi suhu dan kontrol kelembaban. Pengukuran ini dilakukan di dalam dan di luar tapak, tujuannya adalah untuk mengetahui kenyamanan RTH dibandingkan dengan kenyamanan di luar RTH. Pengukuran dilakukan dengan menggunakan thermohygrometer digital THD8.

Masing-masing RTH dibagi kedalam tiga segmen dan di setiap segmen diambif empat titik pengukuran dengan kriteria tertentu. Kriteria untuk pengambilan titik, yaitu: 1) di atas rumput tanpa naungan, 2) di atas perkerasan tanpa naungan, 3) di atas rumput di bawah naungan pohon, dan 4) di atas perkerasan di bawah naungan pohon. Pengukuran dilakukan saat pagi (pukul 07.00-09.00 WIB), siang (pukul 11.00-13.00 WIB), dan sore hari (pukul 15.00-17.00 WIB) pada setiap RTH. Pada setiap waktu pengukuran dilakukan tiga kali pengulangan pada hari yāng berbeda hingga didapatkan suhu dan kelembaban udara rata-rata di masing-masing RTH. Pengukuran di luar RTH dilakukan dengan menentukan titik pengukuran yang berjarak kurang lebih 10 meter ke arah luar dari RTH (Gambar 46). Titik pengukuran adalah lokasi yang mudah dijangkau dan disesuaikan dengan kondisi eksisting pada tapak.

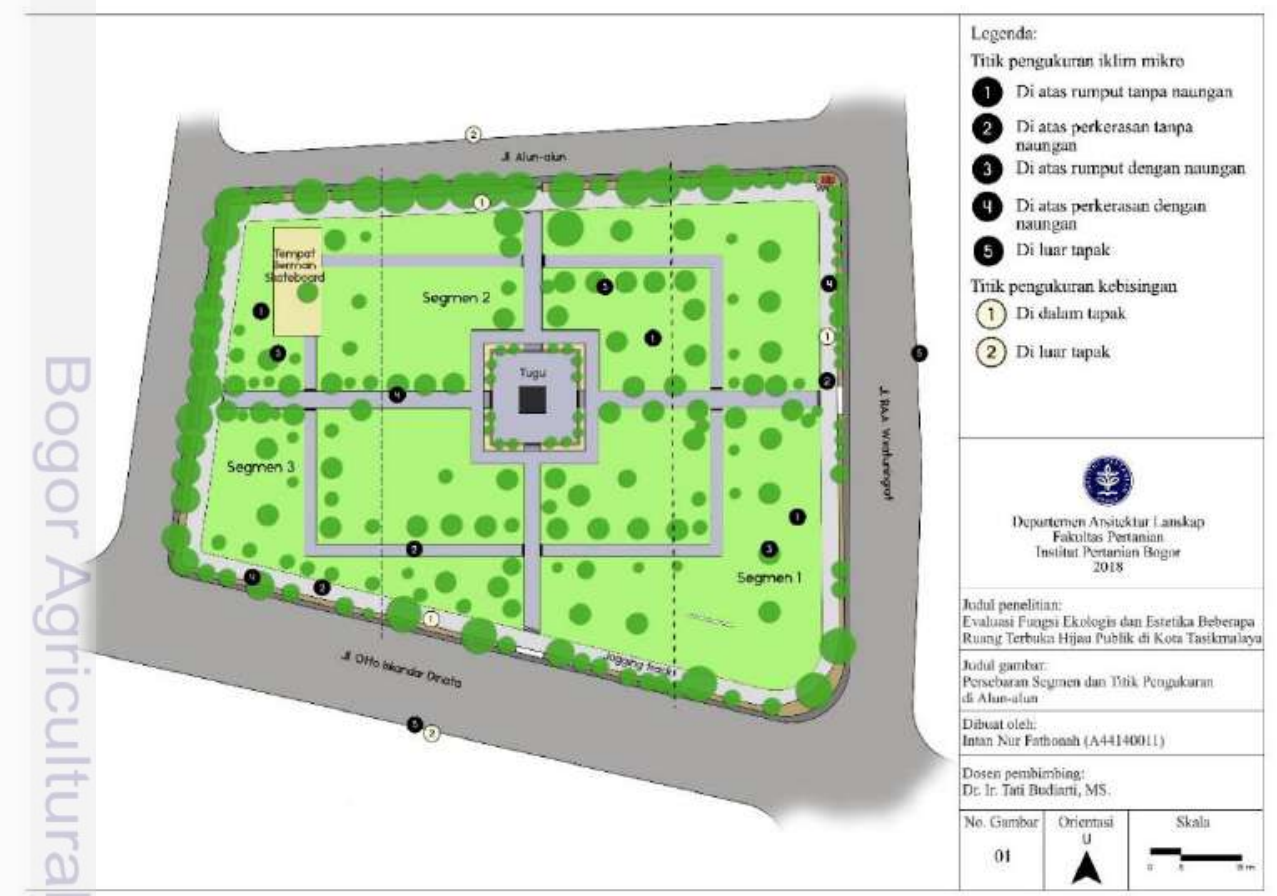

Gambar 4 Persebaran segmen dan titik pengukuran di Alun-alun 


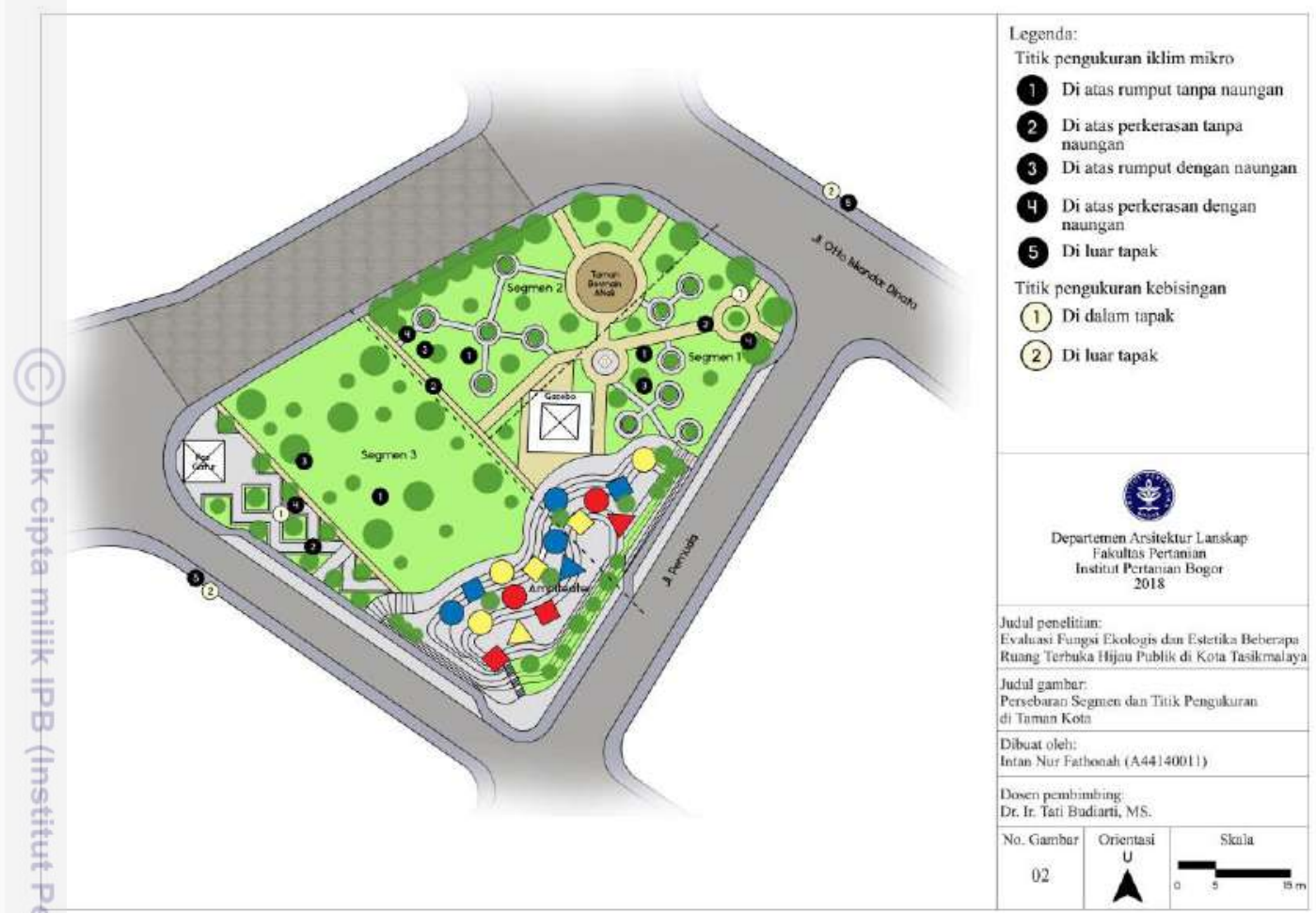

Gambar 5 Persebaran segmen dan titik pengukuran di Taman Kota
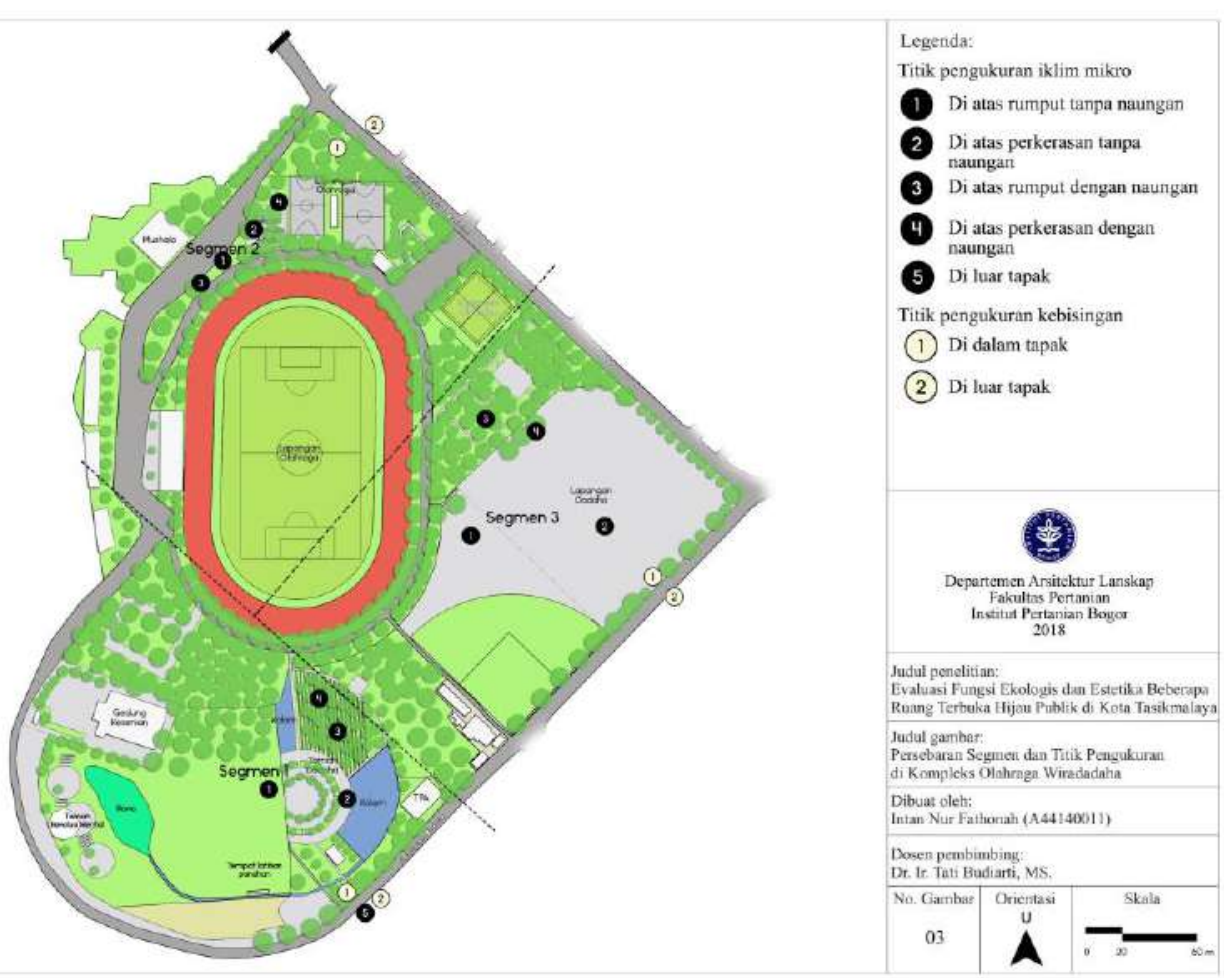

Gambar 6 Persebaran segmen dan titik pengukuran di Kompleks Olahraga Wiradadaha 


\section{c. Pengukuran Tingkat Kebisingan}

Pengukuran kebisingan dilakukan dengan menggunakan sound level meter Lutron SL4012. Pengukuran tingkat kebisingan dilakukan di dalam dan di luar RTH. Hal ini dilakukan untuk mengetahui efektivitas tanaman dalam mengurangi kebisingan dari luar. Titik pengukuran berjarak 5 meter dari batas tepi tapak ke arah dalam tapak dan ke arah luar tapak. Titik pengukuran ditentukan berdasarkan jarak terdekat dari sumber kebisingan, seperti jalan raya.

\section{d. Pemotretan Foto Lanskap}

Objek pengambilan foto ditentukan berdasarkan arah biasanya pengunjung memandang ke arah dalam tapak. Jumlah foto lanskap yang diambil yaitu sebanyak foto lanskap itu dapat mewakili lanskap masing-masing RTH. Titik pemotretan yang dilakukan adalah dengan sudut pandang sejajar dan posisi setinggi mata. Pemotretan dilakukan dengan menggunakan kamera digital Sony DSC-W310. Gambar diambil dengan titik fokus tertinggi dan diusahakan tidak terhalang oleh bangunan atau tanaman lain.

e. Persepsi dan Preferensi Masyarakat

Pengambilan data sosial berupa persepsi dan preferensi pengunjung dilakukan dengan wawancara melalui panduan kuesioner kepada pengunjung RTH. Waktu-wawancara kepada responden bersamaan dengan pengambilan data iklim mikro. Pertanyaan yang diberikan terkait karakteristik pengunjung, persepsi, dan preferensi pengunjung mengenai RTH. Jumlah responden untuk setiap RTH publik yaitu 30 responden sehingga total responden dari empat RTH publik yang diteliti sebanyak 120 responden.

\section{Analisis}

Analisis data dilakukan secara kualitatif dan kuantitatif. Hasil inventarisasi dianalisis berdasarkan fungsi ekologis dan estetika dengan masing-masing metodenya. Proses analisis fungsi ekologis menghasilkan penilaian fungsi modifikasi suhu, kontrol kelembaban, penahan angin, dan peredam kebisingan terhadap masing-masing RTH yang kemudian dibandingkan dengan hasil pengukuran suhu, kelembaban, dan kebisingan, serta diketahuinya tingkat kenyamanan thermal di masing-masing RTH. Proses analisis fungsi estetika menghasilkan tingkat kualitas estetika lanskap dan peta penilaian kualitas estetika lanskap di masing-masing RTH.

\section{a. Analisis Fungsi Ekologis}

Dasar penilaian untuk aspek fungsi ekologis disesuaikan dengan kriteria fungsi tanaman lanskap berdasarkan literatur (Tabel 4). Variabel penilaian untuk fungsi ekologis pohon terdiri atas fungsi modifikasi suhu, kontrol kelembaban udara, penahan angin, dan peredam kebisingan. Teknik penilaian fungsi ekologis menggunakan rumus Key Performance Index (KPI) untuk memberi nilai pada masing-masing kriteria (Hidayat 2008). Nilai tertinggi yang diberikan adalah 4 dan yang terendah adalah 1 . Pemberian nilai rentang 4-1 pada setiap jenis pohon dilakukan berdasarkan hasil pengurutan kesesuaian terhadap masing-masing kriteria. Hasil penilaian keseluruhan dibedakan menjadi kategori sangat baik, baik, 
sedang, dan buruk, serta dihitung persentasenya terhadap total jenis dan total individu tanaman.

Tabel 4 Kriteria penilaian fungsi ekologis

\begin{tabular}{ll}
\hline \multicolumn{1}{c}{ Variabel } & \multicolumn{1}{c}{ Kriteria Penilaian } \\
\hline Modifikasi Suhu & 1. Ketinggian kanopi lebih dari 2 m (Simonds 1983) \\
(Peneduh) & $\begin{array}{l}\text { 2. Bentuk tajuk spreading, bulat, dome, irregular (DPU } \\
\text { Dirjen Bina Marga 1996) } \\
\text { 3. Massa daun padat (DPU Dirjen Bina Marga 1996) } \\
\text { 4. Daun tebal (Carpenter et al. 1975) }\end{array}$ \\
Kontrol Kelembaban & 1. Bentuk tajuk bulat dan bulat terbuka (Femy 2014) \\
2. Berdaun jarum atau kasar (Grey dan Deneke 1978) \\
3. Tekstur batang kasar (Grey dan Deneke 1978) \\
4. Jumlah daun banyak (Carpenter et al. 1975) \\
1. Tanaman tinggi (Carpenter et al. 1975) \\
2. Daunnya tidak mudah gugur (Dahlan 1992) \\
3. Massa daun rapat (DPU Dirjen Bina Marga 1996) \\
4. Berdaun tebal (DPU Dirjen Bina Marga 1996) \\
1. Tajuk rapat dan massa daun rapat (DPU Dirjen \\
Pengina Marga 1996) \\
2. Berdaun tebal (Grey dan Deneke 1978) \\
3. Struktur cabang dan batang besar (Grey dan \\
Deneke 1978
\end{tabular}

Sumber: Mahardi 2013 dengan modifikasi

Penilaian

Kategori KPI:

$$
\mathrm{KPI}=\frac{\text { jumlah masing-masing kriteria penilaian }}{\text { jumlah ideal (total maksimum)masing-masing kriteria }}
$$

Nilai 1: Buruk, bila < $40 \%$ kriteria terpenuhi Nilai 2: Sedang, bila 41-60\% kriteria terpenuhi
Nilai 3: Baik, bila 61-80\% kriteria terpenuhi Nilai 4: Sangat baik, bila $>81 \%$ kriteria terpenuhi

$$
\begin{aligned}
\text { Persentase terhadap total jenis } & =\frac{\text { jumlah jenis tanaman kategori } \mathrm{x}}{\text { total jenis tanaman }} \times 100 \% \\
\text { Persentase terhadap total individu } & =\frac{\text { jumlah individu tanaman kategori } \mathrm{x}}{\text { total individu tanaman }} \times 100 \%
\end{aligned}
$$

\section{Skor per RTH}

(Persentase terhadap total individu kategori Buruk x 1) + (Persentase terhadap total individu kategori Sedang x 2) + (Persentase terhadap total individu kategori

Baik x 3) + (Persentase terhadap total individu kategori Sangat baik x 4)

Kategori skor per RTH*:

Nilai 1: Buruk, bila skor $<200$

Nilai 2: Sedang, bila skor 201-300

Nilai 3: Baik, bila skor $>300$

*Kecuali dalam fungsi kontrol kelembaban, nilai 1: buruk; nilai 2: baik; nilai 3: buruk 
Hasil penilaian selanjutnya dibandingkan dengan pengukuran iklim mikro yang meliputi suhu udara dan kelembaban udara dianalisis dengan membandingkan kondisi iklim mikro pada tapak dengan kondisi kenyamanan ideal. Indeks kenyamanan iklim mikro dihitung menggunakan rumus Thermal Humidity Index (THI). Berdasarkan Mulyana, Laras, Budi (2003) dalam Pratama (2013) kondisi nyaman ideal di Indonesia adalah indeks THI yang berkisar antara 20-26. Formulasi THI adalah sebagai berikut:

$$
\mathrm{THI}=0.8 \mathrm{~T}+(\mathrm{RH} \times \mathrm{T}) / 500
$$

Keterangan:

THI = Thermal Humidity Index

$\mathrm{T} \quad=$ Suhu udara $\left({ }^{\circ} \mathrm{C}\right)$

$\mathrm{RH}=$ Kelembaban udara $(\%)$

b. Analisis Baku Mutu Tingkat Kebisingan

Setiap tempat/kawasan memiliki baku mutu tingkat kebisingan yang menjadi patokan kesesuaian tingkat kebisingan yang masih dapat memberi kenyamanan untuk didengar di tempat/kawasan tersebut. Baku mutu tingkat kebisingan ini disesuaikan dengan Keputusan Menteri Lingkungan Hidup No. KEP-48 (Tabel 5). Hasil pengukuran kebisingan di ketiga RTH dibandingkan dengan baku mutu tingkat kebisingan untuk kawasan rekreasi karena dominasi kegiatan yang dilakukan pengunjung di ketiga RTH yaitu rekreasi.

Tabel 5 Baku mutu tingkat kebisingan

\begin{tabular}{ccc}
\hline No & \multicolumn{1}{c}{$\begin{array}{c}\text { Peruntukan Kawasan/Lingkungan } \\
\text { Kegiatan }\end{array}$} & $\begin{array}{c}\text { Tingkat Kebisingan } \\
(\mathrm{dBA})\end{array}$ \\
\hline $\mathrm{A} \quad \begin{array}{l}\text { Peruntukan Kawasan: } \\
\text { 1. Perumahan dan permukiman }\end{array}$ & 55 \\
2. Perdagangan dan jasa & 70 \\
3. Perkantoran dan perdagangan & 65 \\
4. Ruang Terbuka Hijau & 50 \\
5. Industri & 70 \\
6. Pemerintahan dan fasilitas umum & 60 \\
7. Rekreasi & $\mathbf{7 0}$ \\
8. Khusus: & \\
$\quad$ Bandara udara *) & 60 \\
$\quad$ Stasiun kereta api & 70 \\
$\quad$ Pelabuhan laut & \\
$\quad$ Cagar budaya *) & 55 \\
Bingkungan Kegiatan & 55 \\
1. Rumah sakit atau sejenisnya & 55 \\
\hline 2. Sekolah atau sejenisnya & \\
3. Tempat ibadah atau sejenisnya &
\end{tabular}

*) disesuaikan dengan Ketentuan Menteri Perhubungan

Sumber: KepMNLH No. KEP-48/MENLH/11/1996 


\section{c. Analisis Kualitas Estetika}

Penilaian dan evaluasi untuk kualitas estetika dilakukan dengan menerapkan metode Scenic Beauty Estimation (SBE) yang diperkenalkan oleh Daniel dan Boster (1976). Penerapan metode SBE terdiri dari tiga langkah utama, yaitu 1) pengambilan foto lanskap, 2) presentasi slide foto, dan 3) analisis data.

Responden yang dituju adalah orang yang sudah mendapatkan pemahaman lebih jauh tentang ilmu arsitektur lanskap, yaitu mahasiswa Departemen Arsitektur Lanskap IPB semester 6 dan/atau 8 sebanyak 34 mahasiswa yang telah mengambil MK. Teori Desain Lanskap. Harapannya responden dapat menilai secara objektif terkait kualitas estetika yang akan dievaluasi. Hasil penilaian responden selanjutnya diolah secara statistik dengan perhitungan SBE berdasarkan skala penilaian 1-10.

Kemudian dilakukan tahap analisis terhadap data yang diperoleh dari tahap presentasi slide. Analisa data ditujukan untuk mendapatkan nilai SBE yaitu indeks kuantitas pendugaan keindahan suatu lanskap (Daniel dan Boster 1976). Tiap peringkat nilai akan dihitung frekuensi kumulatif, peluang kumulatif, nilai Z, dan nilai $\mathrm{Z}$ rata - rata. Kemudian ditentukan satu nilai $\mathrm{Z}$ dari foto lanskap tertentu sebagai standar (nilai $Z$ yang paling mendekati nol). Nilai SBE diformulasikan sebagai berikut:

Keterangan:

$$
\text { SBEx }=(Z L x-Z L s) \times 100
$$

SBEx = Nilai SE lanskap ke $\mathrm{x}$

ZLx = Nilai rata-rata Z lanskap ke $\mathrm{x}$

ZLs = Nilai rata-rata $Z$ lanskap standar

Berdasarkan nilai SBE yang diperoleh, setiap objek dikelompokkan menjadi kualitas estetika rendah, kualitas estetika sedang, dan kualitas estetika tinggi. Pengelompokkan ini dilakukan dengan menggunakan standar oleh Daniel dan Boster (1976) dalam Mahardi (2013), yaitu kualitas estetika rendah memiliki nilai SBE $<-20$, kualitas estetika sedang apabila memiliki nilai SBE antara -20 sampai 20, dan kualitas estetika tinggi apabila nilai SBE $>20$.

\section{d. Analisis Persepsi dan Preferensi Pengunjung}

Berdasarkan penyebaran kuesioner, dapat diketahui karakteristik pengunjung, tujuan, serta keinginan pengunjung pada tapak. Data persepsi dan preferensi pengunjung diolah dengan menggunakan metode statistika deskripsi. Hasil pengolahan data disajikan dalam bagan atau diagram untuk penjelasan yang lebih mudah.

\section{Sintesis}

Pada tahap sintesis dirumuskan rekomendasi perbaikan penataan tanaman di Alun-alun, Taman Kota, dan Kompleks Olahraga Wiradadaha terkait aspek fungsi ekologis dan estetika. Rekomendasi ini dirumuskan berdasarkan hasil analisis dan literatur. Rekomendasi perbaikan penataan tanaman RTH diharapkan dapat digunakan sebagai acuan bagi pemerintah daerah dalam pengembangan di setiap RTH. 


\title{
HASIL DAN PEMBAHASAN
}

\author{
Kondisi Umum
}

\section{Letak, Luas, dan Batas Lokasi}

Penelitian dilakukan di tiga RTH publik Kota Tasikmalaya, yaitu Alun-alun, Taman Kota, dan Kompleks Olahraga Wiradadaha. Alun-alun secara administratif berada di Jalan Otto Iskandar Dinata, Kelurahan Empangsari, Kecamatan Tawang dan secara geografis terletak pada $7^{\circ} 19^{\prime} 35^{\prime \prime}$ LS $108^{\circ} 13^{\prime} 27^{\prime \prime}$ BT. Alun-alun memiliki luas 2 ha dengan batas pagar dari semen cor. Sebelah Barat dan Utara Alun-alun berbatasan dengan Jalan Alun-alun, sebelah Timur berbatasan dengan Jalan RAA. Wiratuningrat, dan sebelah Selatan berbatasan dengan Jalan Otto Iskandar Dinata.

Taman Kota secara administratif berada di Jalan KH. Zaenal Mustofa, Kelurahan Yudanagara, Kecamatan Cihideung, secara geografis terletak pada $7^{\circ} 19^{\prime} 35^{\prime \prime}$ LS $108^{\circ} 13^{\prime} 15^{\prime \prime}$ BT, dan memiliki luas 2 ha. Taman Kota tidak dibatasi dengañ pagar sehingga terlihat lebih terbuka. Sebelah Barat Taman Kota berbatasan langsung dengan Masjid Agung Tasikmalaya, sebelah Utara berbatasan dengan persimpangan antara Jalan Otto Iskandar Dinata dan Jalan Doktor Sukarjo, sebelah Timur berbatasan dengan Jalan Pemuda, dan sebelah Selatan berbatasan dengan persimpangan Jalan Pemuda dan Jalan Yudanagara.

- Kompleks Olahraga Wiradadaha secara administratif berada di Jalan Wiradadaha (Dadaha), Kelurahan Nagarawangi, Kecamatan Cihideung dan secara geografis terletak pada $7^{\circ} 20^{\prime} 12^{\prime \prime}$ LS $108^{\circ} 13^{\prime} 16.5^{\prime \prime}$ BT. Kompleks Olahraga Wiradadaha memiliki luas 8 ha. Sebagian dari batas Kompleks Olahraga Wiradadaha dibatasi oleh pagar besi dan sebagian area lainnya hanya dibatasi oleh pepohonan peneduh. Sebelah Barat Kompleks Olahraga Wiradadaha berbatasan langsung dengan pemukiman warga, sebelah Utara dibatasi oleh Jalan Wiradadaha, sedangkan sebelah Timur dan Selatan dikelilingi oleh Jalan Lingkar Dadaha.

\section{Sejarah dan Keadaan Fisik Alun-alun, Taman Kota, dan Kompleks Olahraga Wiradadaha}

Alun-alun telah didirikan sejak area tersebut masih merupakan bagian dari Kabupaten Tasikmalaya. Alun-alun sempat tidak terurus setelah pergantian status administrasi area Kabupaten Tasikmalaya tersebut menjadi Kota Tasikmalaya pada tahun 2002. Setelah diakuisisi oleh Pemerintahan Kota Tasikmalaya pada tahun 2011, Alun-alun akhirnya direvitalisasi. Revitalisasi Alun-alun dilakukan dengan memperbaiki perkerasan-perkerasan yang telah rusak. Penambahan tanaman khususnya tanaman estetika seperti kamboja (Plumeria rubra), tabebuia (Tabebuia chrysant), cemara norfolk (Araucaria heterophylla), dan beberapa jenis palem. Pepohonan tua di sekeliling area Alun-alun seperti krei payung (Felicium decipiens), biola cantik (Ficus lyrata), trembesi (Samanea saman) tetap dipertahankan. 
Alun-alun memiliki desain geometris mengikuti bentuk dari tapaknya dengan axis tegak lurus memotong tugu. Tugu yang menjadi focal point Alun-alun membentuk patung Mak Eroh dan Abdul Rozak yang merupakan pejuang lingkungan dari Tasikmalaya. Jasa mereka dihargai oleh pemerintahan Orde Baru saat itu dengan penghargaan Kalpataru (Gambar 7a). Tugu tersebut juga dihiasi oleh relief disetiap sisi kubusnya. Relief-relief yang terukir menceritakan kondisi potensi alam, masyarakat, dan kerajinan yang dimiliki Tasikmalaya (Gambar 7b). Fasilitas yang dimiliki oleh Alun-alun adalah jalur jogging dan WC umum (Gambar 8).
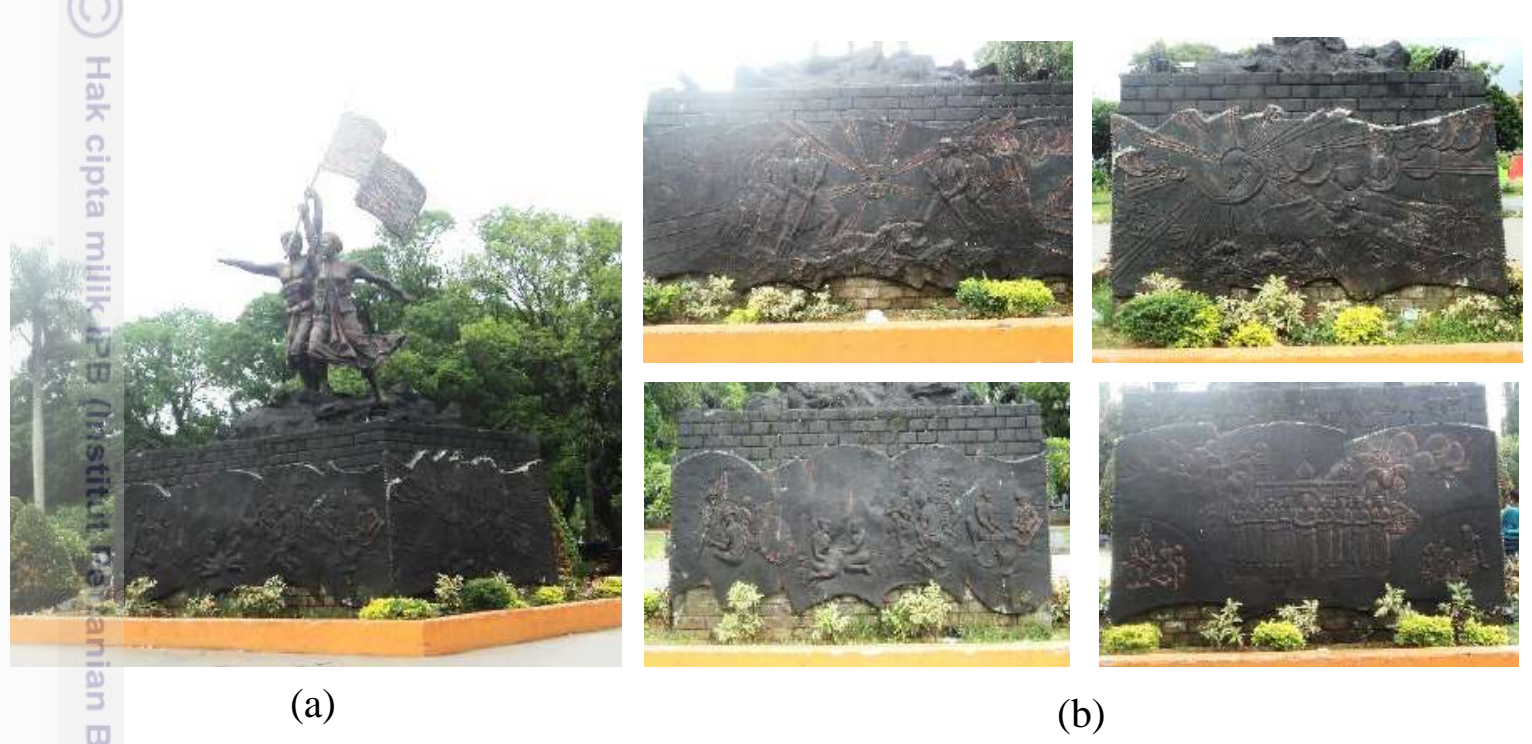

(a)

(b)

Gambar 8 Tugu Alun-alun: (a) patung Mak Eroh dan Abdul Rozak, (b) relief-relief penggambaran Tasikmalaya

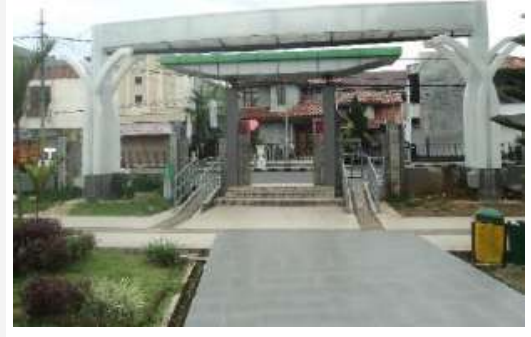

(a)

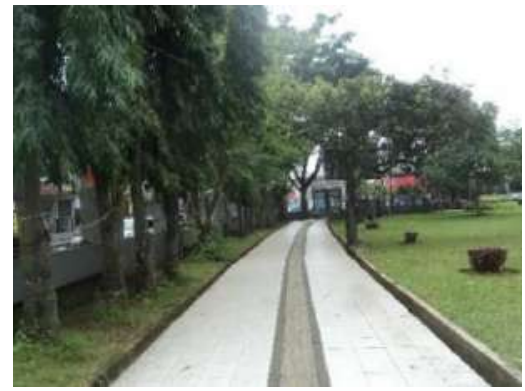

(c)

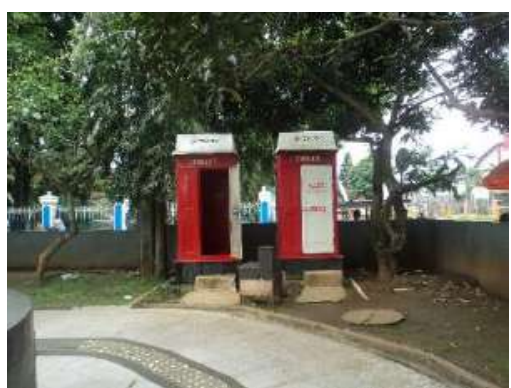

(b)

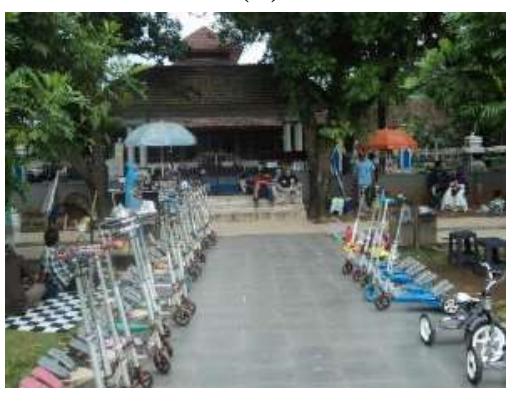

(d)

Gambar 7 Kondisi eksisting Alun-alun: (a) gerbang, (b) WC umum, (c) jogging track, dan (d) pedagang 
Setiap hari Alun-alun selalu ramai dikunjungi pengunjung. Pengunjung banyak yang datang untuk berolahraga seperti jogging dan senam. Ada juga pengunjung yang datang ke Alun-alun untuk berekreasi, berkumpul, membeli makanan, bahkan melakukan kegiatan ekstrakulikuler. Selain pengunjung, Alunalun juga ramai dikunjungi oleh pedagang terutama di akhir pekan.

Taman Kota didirikan pada tahun 2015 di atas tanah yang dulunya merupakan Kantor Bupati Kabupaten Tasikmalaya. Taman Kota memiliki desain taman organik yang didominasi oleh bentuk lingkaran. Fasilitas yang dimiliki oleh Taman Kota yaitu tempat bermain anak, gazebo, dan WC umum yang menyatu dengan Pos Gatur Polisi (Gambar 9). Ampiteater, tempat bermain anak, dan parklet yang dibentuk oleh beberapa planter box menjadi titik-titik pengunjung berkumpul.

Taman Kota juga memiliki tugu peninggalan dari Kantor Bupati Kabupaten Tasikmalaya. Tugu yang berbentuk limas tumpul ini dikelilingi oleh parit kecil berisi batuan alam. Tugu tersebut menjadi pusat perkerasan di area parklet. Tugu tersebut merupakan simbol peresmian Kota Administratif Tasikmalaya yang diresmikan oleh Menteri Dalam Negeri saat itu, Amir Machmud, pada 3 November 1976.

Tugu tersebut dapat dijadikan icon yang menarik dan bukti sejarah awal dibentuknya Kota Tasikmalaya namun tugu belum terpelihara dan diperindah dengan baik (Gambar 10). Tanaman di sekeliling tugu ditanam seadanya dengan drasena (Dracaena sp.) dan beberapa tanaman penutup tanah lain yang keberadaannya seperti gulma karena tidak dilakukan penyulaman.

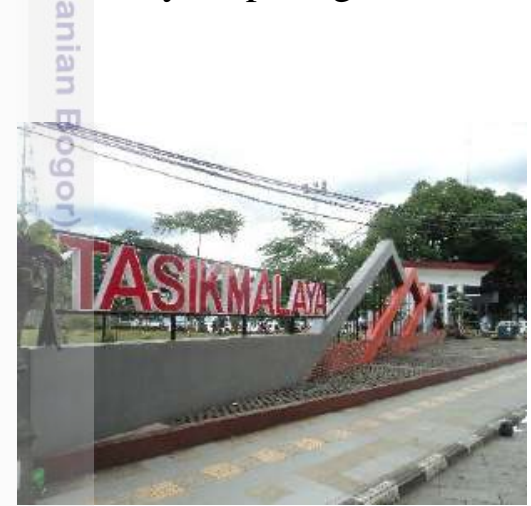

(a)

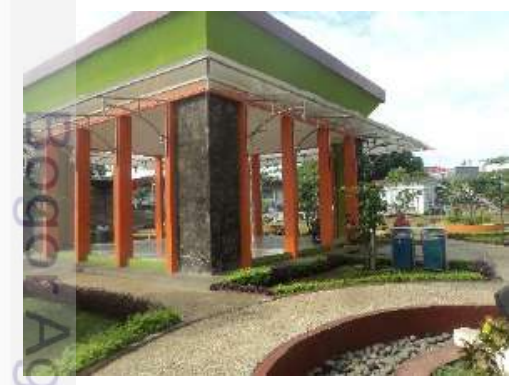

(c)

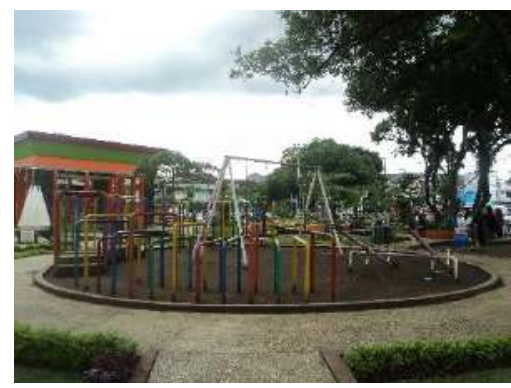

(b)

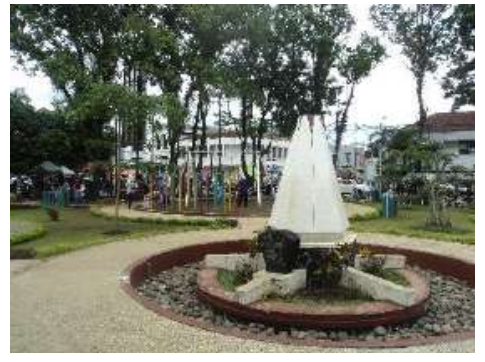

(d)

Gambar 9 Kondisi eksisting Taman Kota: (a) signage, (b) tempat bermain anak, (c) gazebo, dan (d) tugu peresmian Kota Tasikmalaya 


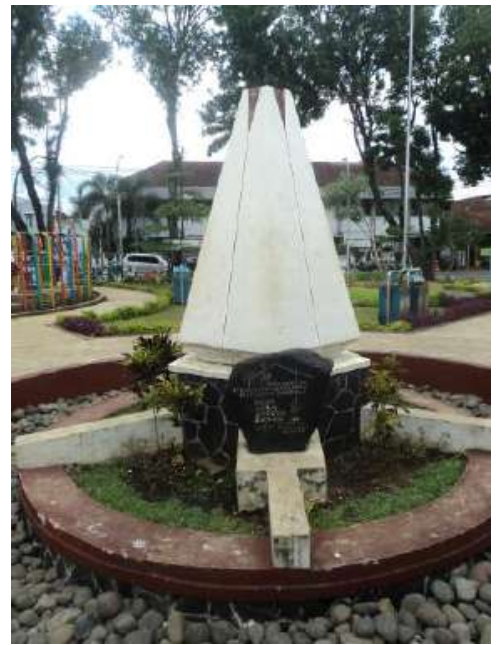

(a)
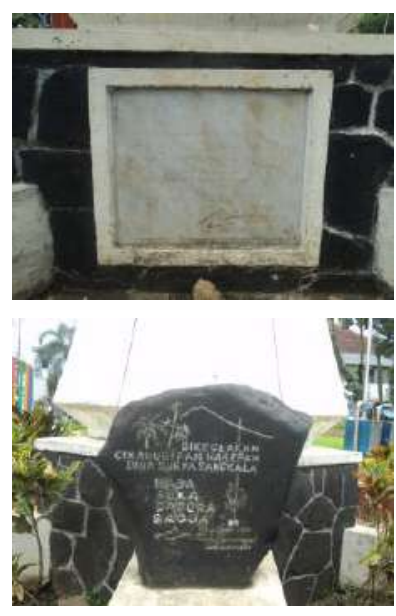

(b)

Gambar 10 Tugu peresmian Kota Tasikmalaya: (a) bentuk tugu dan (b) prasasti peresmian Kota Tasikmalaya

Taman Kota berada tepat di tengah pusat kota sehingga sering dikunjungi sebagai tempat singgah atau tempat titik temu. Selain sebagai tempat singgah atau tempat titik temu, Taman Kota juga sering dikunjungi sebagai tempat rekreasi. Plaza yang berada di antara taman dan Masjid Agung seringkali menjadi pusat bermain dan berbelanja terutama pada hari Rabu dan akhir pekan. Frekuensi pengunjung yang tinggi pada hari-hari tertentu menyebabkan banyak sampah berserakan namun pengelolaan kebersihan yang rutin telah meminimalisir dampak dari sampah tersebut.

Nama Kompleks Olahraga Wiradadaha atau lebih sering disebut Dadaha oleh masyarakat diambil dari gelar bupati pertama daerah Sukapura, asal mula daerah Tasikmalaya, yaitu Wiradadaha I. Kompleks Olahraga Wiradadaha yang telah berdiri sejak masih merupakan aset Kabupaten Tasikmalaya memiliki permasalahan yang sama seperti Alun-alun. Perbaikan dan pemeliharaan Kompleks Olahraga Wiradadaha oleh Pemerintahan Kota Tasikmalaya akhirnya baru dapat dilakukan pada tahun 2015. Kompleks Olahraga Wiradadaha memiliki bermacam fasilitas, yaitu lapangan olahraga (basket dan voli), tempat berlatih panahan, tempat bermain anak, stadion sepak bola, lapangan terbuka, gedung-gedung olahraga, taman-taman, gedung kesenian, dan mushala (Gambar 11). Kompleks Olahraga Wiradadaha memiliki desain organik dengan pusat Stadion Wiradadaha. Fasilitasfasilitas seperti lapangan olahraga, taman, dan terdapat juga hutan kota berada di sekeliling Stadion Wiradadaha.

Kompleks Olahraga Wiradadaha menjadi salah satu pusat olahraga masyarakat Kota Tasikmalaya. Terutama pada akhir pekan, Kompleks Olahraga Wiradadaha ramai dikunjungi. Selain tempat olahraga, beberapa kali kegiatan kesenian pun dilakukan, baik di gedung kesenian maupun di lapangan terbuka. 


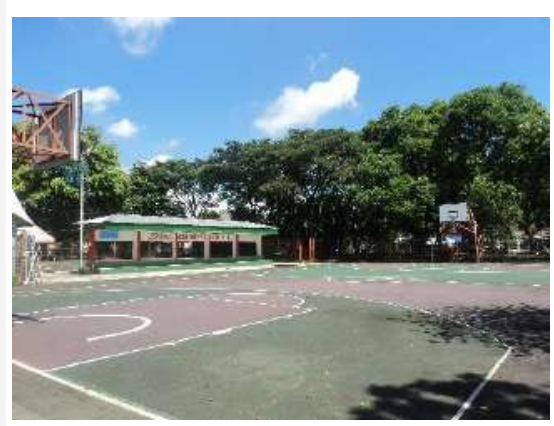

(a)

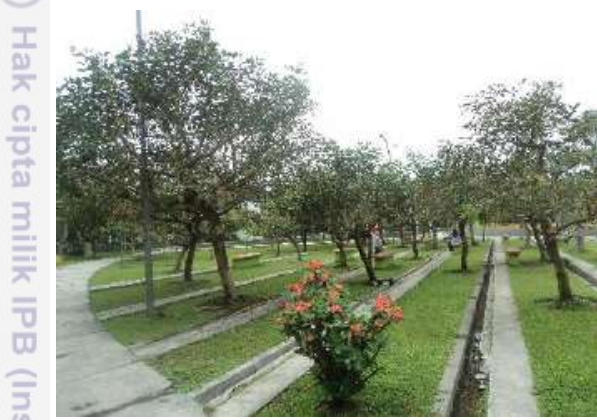

(c)

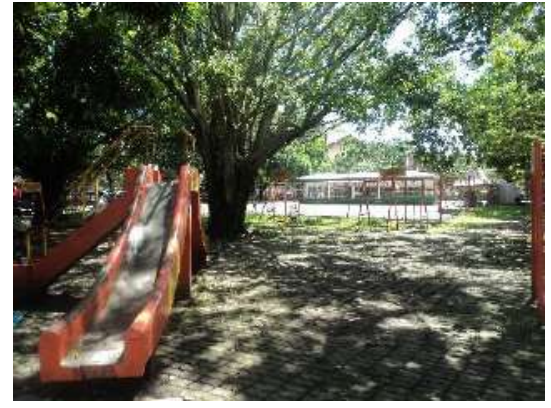

(b)

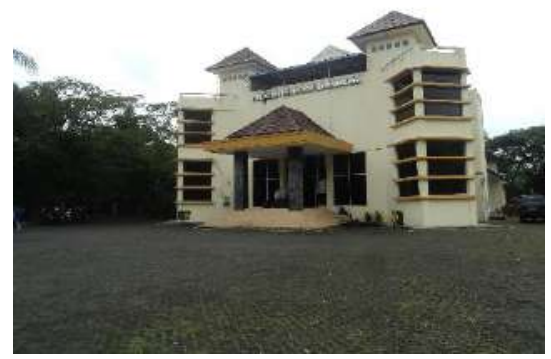

(d)

Gambar 11 Kondisi eksisting Kompleks Olahraga Wiradadaha: (a) lapangan basket, (b) tempat bermain anak, (c) Taman Dadaha, dan (d) gedung kesenian

\section{Identifikasi Jenis dan Fungsi Tanaman}

Tiga lokasi penelitian, yaitu Alun-alun, Taman Kota, dan Kompleks Olahraga Wiradadaha memiliki karakteristik dan didirikan pada waktu yang berbeda. Perbedaan karakteristik dan waktu pendirian RTH yang berbeda mempengaruhi pula pada tipe dan kondisi tanaman pada setiap RTH.

\section{Alun-alun}

Alun-alun telah didirikan sejak Tasikmalaya masih merupakan bagian dari Kabupaten Tasikmalaya sehingga tanaman eksisting yang mengelilingi Alun-alun memiliki ukuran yang cukup besar. Jenis tanaman yang mengelilingi Alun-alun diantaranya lamtoro (Leucaena leucocephala), bunga kupu-kupu (Bauhinia purpurea), krei payung (Felicium decipiens), biola cantik (Ficus lyrata), glodogan tiang (Polyalthia longifolia), angsana (Pterocarpus indicus), dan trembesi (Samanea saman). Fungsi dari tanaman eksisting rata-rata adalah peneduh.

Alun-alun Kota Tasikmalaya direvitalisasi pada tahun 2011, sejak itu jenis tanaman di Alun-alun bertambah. Tanaman baru banyak yang memiliki fungsi estetika seperti cemara norfolk (Araucaria heterophylla), dadap merah (Erythrina crista-galli), kamboja (Plumeria rubra), dan tabebuia (Tabebuia chrysant), dan beberapa jenis palem.

Jumlah jenis pohon yang berada di Alun-alun yaitu 18 spesies dan jumlah total individu sebanyak 207 pohon (Tabel 6). Tanaman yang sering ditemui di Alunalun yaitu dadap merah (Erythrina crista-galli) dan krei payung (Felicium 
decipiens) yang berfungsi sebagai estetika dan peneduh, serta pucuk merah (Syzygium campanulatum) yang berfungsi sebagai pengarah.

Tabel 6 Jenis dan fungsi pohon di Alun-alun

\begin{tabular}{|c|c|c|c|c|}
\hline No. & Nama ilmiah & Nama lokal & Jumlah & Fungsi \\
\hline 1 & Araucaria heterophylla & Cemara norfolk & 4 & Estetika \\
\hline 2 & Bauhinia purpurea & Bunga kupu-kupu & 11 & Estetika \\
\hline 3 & Bismarckia nobilis & Bismark palm & 17 & Pengarah \\
\hline 4 & Coryota mitis & Palem ekor ikan & 2 & Estetika \\
\hline 5 & Cyrtostachys renda & Palem merah & 4 & Esetika \\
\hline 6 & Erythrina crista-galli & Dadap merah & 33 & Esetika \\
\hline 7 & Felicium decipiens & Krei payung & 20 & Peneduh \\
\hline 8 & Ficus elastica & Beringin karet & 1 & Peneduh \\
\hline 9 & Ficus lyrata & Biola cantik & 6 & Peneduh \\
\hline$\overline{1} 0$ & Leucaena leucocephala & Lamtoro & 1 & Peneduh \\
\hline 11 & Mangifera indica & Mangga & 2 & Peneduh \\
\hline 12 & Plumeria rubra & Kamboja & 7 & Estetika \\
\hline 13 & Polyalthia longifolia & Glodogan tiang & 15 & Pengarah \\
\hline 14 & Pterocarpus indicus & Angsana & 1 & Peneduh \\
\hline 15 & Samanea saman & Trembesi & 5 & Peneduh \\
\hline 16 & Syzygium campanulatum & Pucuk merah & 39 & Pengarah \\
\hline 17 & Tabebuia chrysant & Tabebuia & 18 & Estetika \\
\hline 18 & Wodyetia bifurcata & Palem ekor tupai & 21 & Pengarah \\
\hline
\end{tabular}

Pola penanaman yang mendominasi di Alun-alun yaitu pola linear mengikuti jalur perkerasan. Tanaman yang ditanam secara linear ada yang sejenis dan campuran. Selain ditanam secara linear, ada juga tanaman yang ditanam berkelompok seperti kamboja (Plumeria rubra).

Pepohonan memang tanaman yang mendominasi di Alun-alun namun ada juga struktur tanaman lain seperti tanaman penutup tanah dan rumput. Rumput tumbuh dengan baik sehingga pengunjung juga dapat duduk di atas rumput. Bermacam tanaman penutup tanah ditanam berkelompok di beberapa titik sebagai pemberi nilai estetika.

\section{Taman Kota}

Taman Kota didirikan pada tahun 2015 sehingga sebagian besar pepohonan di Taman Kota masih memiliki tinggi sedang kecuali krei payung (Felicium decipiens). Terdapat 8 jenis pohon dengan jumlah total individu 90 pohon (Tabel 7). Tanaman yang paling sering ditemui adalah bonsai kimeng (Ficus microcarpa). Jenis beringin yang terkenal dengan kerimbunannya tidak terlihat di Taman Kota karena beringin tersebut dipangkas secara rutin dan dijadikan salah satu tanaman estetika. Tanaman lain yang sering ditemui yaitu ketapang kencana (Terminalia mantaly) yang berfungsi sebagai estetika.

Tanaman di Taman Kota ditanam dengan pola berkelompok campuran. Tanaman yang ditanam dengan pola linear hanya tanaman dengan fungsi pengarah 
seperti glodogan tiang (Polyalthia longifolia). Taman Kota didominasi oleh tanaman berfungsi estetika dengan ketinggian sedang dan belum tumbuh maksimal sehingga siang hari masih terasa terik.

Tabel 7 Jenis dan fungsi pohon di Taman Kota

\begin{tabular}{lllcl}
\hline No. & \multicolumn{1}{c}{ Nama ilmiah } & \multicolumn{1}{c}{ Nama lokal } & Jumlah & \multicolumn{1}{c}{ Fungsi } \\
\hline 1 & Cyrtostachys renda & Palem merah & 10 & Estetika \\
2 & Erythrina crista-galli & Dadap merah & 13 & Estetika \\
3 & Felicium decipiens & Krei payung & 13 & Peneduh \\
4 & Ficus microcarpa & Kimeng & 20 & Estetika \\
5 & Leucaena leucocephala & Lamtoro & 11 & Peneduh \\
6 & Polyalthia longifolia & Glodogan tiang & 5 & Pengarah \\
7 & Tabebuia chrysant & Tabebuia & 3 & Estetika \\
8 & Terminalia mantaly & Ketapang kencana & 15 & Estetika \\
\hline
\end{tabular}

Tanaman penutup tanah juga banyak menghiasi terutama di planter box parklet dan sepanjang jalur perkerasan. Tanaman penutup tanah tersebut memberikan nilai estetika karena beragam jenis dan warnanya. Taman Kota juga memiliki lahan berumput yang berada di depan ampiteater. Rerumputan di lahan tersebut masih perlu penyiraman yang rutin karena belum tumbuh dengan baik.

\section{Kompleks Olahraga Wiradadaha}

Kompleks Olahraga Wiradadaha memiliki jumlah indvidu tanaman terbanyak dibandingkan kedua lokasi lain karena didukung oleh lahan yang lebih luas. Terdapat 36 jenis pohon dengan jumlah total individu 807 pohon (Tabel 8). Jenis tanaman terbanyak di Kompleks Olahraga Wiradadaha adalah mahoni (Switenia mahogany) yang ditanam dengan pola mengelompok di hutan kota dan area kebugaran. Tanaman yang sering ditemui lainnya adalah pucuk merah (Syzygium campanulatum), dadap merah (Erythrina crista-galli), trembesi (Samanea saman), dan bintaro (Cerbera odollam) dengan masing-masing fungsinya.

Tabel 8 Jenis dan fungsi pohon di Kompleks Olahraga Wiradadaha

\begin{tabular}{lllcl}
\hline No. & \multicolumn{1}{c}{ Nama ilmiah } & Nama lokal & Jumlah & \multicolumn{1}{c}{ Fungsi } \\
\hline 1 & Acacia auriculiformis & Akasia & 5 & Peneduh \\
2 & Acacia longifolia & Akasia & 10 & Peneduh \\
3 & Alstonia scholaris & Pulai & 5 & Peneduh \\
4 & Bauhinia purpurea & Bunga kupu-kupu & 6 & Estetika \\
5 & Butia capitata & Jelly palm & 4 & Pengarah \\
6 & Casuarina sp. & Cemara & 14 & Pengarah \\
7 & Cerbera odollam & Bintaro & 78 & Pengarah, estetika \\
8 & Erythrina crista-galli & Dadap merah & 64 & Estetika \\
9 & Felicium decipiens & Krei payung & 33 & Peneduh \\
10 & Ficus benjamina & Beringin & 6 & Peneduh \\
11 & Ficus elastica & Karet kebo & 1 & Peneduh \\
12 & Ficus lyrata & Biola cantik & 53 & Peneduh \\
\hline
\end{tabular}


Tabel 8 Jenis dan fungsi pohon di Kompleks Olahraga Wiradadaha (lanjutan)

\begin{tabular}{lllcl}
\hline No. & \multicolumn{1}{c}{ Nama ilmiah } & \multicolumn{1}{c}{ Nama lokal } & Jumlah & \multicolumn{1}{c}{ Fungsi } \\
\hline 13 & Leucaena leucocephala & Lamtoro & 49 & Peneduh \\
14 & Mangifera indica & Mangga & 22 & Peneduh \\
15 & Manilkara kaukii & Sawo kecik & 33 & Peneduh \\
16 & Maniltoa grandiflora & Pohon sapu tangan & 2 & Peneduh \\
17 & Mimusoph elengi L. & Tanjung & 16 & Peneduh \\
18 & Morinda citrifolia L. & Mengkudu & 3 & Estetika \\
19 & Muntingi calabura & Kersen & 25 & Peneduh \\
20 & Ochroma pyramidale & Balsa & 6 & Pengarah \\
21 & Plumeria rubra & Kamboja & 2 & Estetika \\
22 & Polyalthia fragrans & Glodogan bulat & 3 & Peneduh \\
23 & Polyalthia longifolia & Glodogan tiang & 4 & Pengarah \\
\hline $\mathbf{2} 4$ & Pometia pinnata & Matoa & 11 & Peneduh \\
25 & Psidium guajava & Jambu & 5 & Peneduh \\
26 & Pterocapus indicus & Angsana & 27 & Peneduh \\
27 & Roystone regia & Palem raja & 4 & Pengarah \\
38 & Samanea saman & Trembesi & 74 & Peneduh \\
\hline 29 & Schleichera oleosa & Kesambi & 10 & Peneduh \\
30 & Senna siamea & Johar & 4 & Peneduh \\
31 & Switenia mahogani & Mahoni & 124 & Peneduh, pengarah \\
32 & Syzygium campanulatum & Pucuk merah & 91 & Pengarah \\
33 & Tabebuia chrysant & Tabebuia & 32 & Estetika \\
34 & Terminalia catappa & Ketapang & 8 & Peneduh \\
35 & Terminalia mantaly & Ketapang kencana & 11 & Estetika \\
36 & Wodyetia bifurcata & Palem ekor tupai & 25 & Estetika \\
\hline
\end{tabular}

Tanaman di Kompleks Olahraga Wiradadaha didominasi oleh tanaman bertajuk lebar dan rapat karena telah ditanam sejak pertama Kompleks Olahraga Wiradadaha didirikan. Beberapa tanaman tersebut adalah trembesi (Samanea saman), krei payung (Felicium decipiens), beringin (Ficus benjamina), biola cantik (Ficus lyrata), dan mahoni (Switenia mahogany). Tanaman dengan tajuk lebar dan rapat memberi kesejukan dan kelembaban yang tinggi.

Pola penanaman di Kompleks Olahraga Wiradadaha yaitu berkelompok campuran oleh beberapa jenis tanaman namun selalu ada salah satu tanaman yang mendominasi. Contoh tanaman yang mendominasi yaitu mahoni (Switenia mahogany) di area hutan kota dan dadap merah (Erythrina crista-galii) di area Taman Dadaha. Pola penanaman linear berada di sekeliling luar stadion mengikuti jalur jogging dengan tanaman campuran seperti lamtoro (Leucaena leucocephala), krei payung (Felicium decipiens), trembesi (Samanea saman), dan beberapa pohon peneduh lain. Pola penanaman liner juga dilakukan di beberapa area dengan pohon bintaro (Cerbera odollam) sebagai pengarah. 


\section{Evaluasi Fungsi Ekologis}

Kondisi perkotaan khususnya di Tasikmalaya mengalami penurunan kenyamanan thermal yang ditandai dengan naiknya suhu kota. Suhu di luar ketiga lokasi penelitian berada pada kisaran $28-30{ }^{\circ} \mathrm{C}$. Lokasi penelitian yang berada di pusat kota juga terpengaruhi oleh kebisingan, khususnya kebisingan oleh lalulalang kendaraan. Tanaman di dalam RTH perkotaan memiliki fungsi ekologis penting yaitu sebagai pengameliorasi iklim lingkungan sekitarnya. Ameliorasi iklim dilakukan dengan cara memodifikasi suhu, mengontrol kelembaban, mengatur aliran angin, dan meredam kebisingan. Penelitian ini mengevaluasi seberapa besar pengaruh tanaman, sebagai fungsi ekologis di ketiga lokasi penelitian, dapat mengameliorasi iklim dan meningkatkan kenyamanan thermal.

\section{Fungsi Modifikasi Suhu}

Suhu menjadi salah satu faktor yang mempengaruhi kenyamanan thermal. Kenyamanan thermal sangat dibutuhkan pengunjung di RTH perkotaan yang selalu ramai dikunjungi. Pemilihan dan penataan tanaman peneduh yang tepat dapat mengoptimalkan pemodifikasian suhu hingga mencapai kenyamanan thermal. Beberapa penelitian menyatakan bahwa pemilihan tanaman peneduh yang spesifik dapat berdasarkan struktur dan kerapatan tajuk, ukuran, bentuk, dan warna daun (Abreu-Habrich, Labaki, dan Matzarakis 2015).

Beberapa kriteria tanaman dalam fungsi modifikasi suhu antara lain:

K1= Ketinggian kanopi lebih dari 2 m (Simonds 1983)

K2= Bentuk tajuk spreading, bulat, dome, irregular (DPU Dirjen Bina Marga 1996)

K3= Massa daun padat (DPU Dirjen Bina Marga 1996)

K4= Daun tebal (Carpenter et al. 1975)

Penilain tanaman di setiap lokasi penelitian terhadap fungsi modifikasi suhu berdasarkan keempat kriteria tersebut diuraikan dalam masing-masing Tabel 9, 11, dan 13.

Alun-alun didominasi oleh tanaman berkategori sedang dengan persentase total individu 44\%. Total individu berkategori sedang ini tidak berbeda jauh dengan total individu berkategori baik yaitu sebesar $40 \%$. Keberadaan kedua kategori ini pun tersebar merata.

Penyebaran tanaman berkategori sangat baik berada di sepanjang jalur jogging sehingga memberi keteduhan bagi pengunjung yang sedang berolahraga. Persebaran tanaman berkategori baik tersebar di area berumput. Tanaman berkategori baik di area berumput tidak terlalu dimanfaatkan oleh pengunjung karena pengunjung lebih memilih berkumpul di area tugu dan perkerasan yang memiliki tempat duduk atau perkerasan yang dapat diduduki. Kondisi area tugu yang sering dijadikan tempat berkumpul justru belum memenuhi kenyamanan thermal karena menjelang siang masih terasa panas dan hanya dikelilingi oleh tanaman berkategori sedang (Gambar 12).

Hasil pengukuran suhu udara di Alun-alun pada Tabel 10 menunjukkan bahwa rata-rata suhu di atas rumput dengan naungan merupakan yang terendah. Perbandingan suhu di titik tanpa naungan (titik 1 dan 2) dengan titik dengan naungan (titik 3 dan 4) menunjukkan perbedaan yang cukup tinggi terutama pada 
siang hari. Hal tersebut menunjukkan keefektifan tanaman penaung sebagai pemodifikasi suhu.

Tabel 9 Penilaian aspek fungsi modifikasi suhu di Alun-alun

\begin{tabular}{|c|c|c|c|c|c|c|c|}
\hline \multirow{2}{*}{ Nama ilmiah } & \multirow{2}{*}{ Nama lokal } & \multicolumn{4}{|c|}{$\begin{array}{l}\text { Kriteria fungsi modifikasi } \\
\text { suhu } \\
\end{array}$} & \multirow{2}{*}{$\begin{array}{l}\text { Skor } \\
(\%)\end{array}$} & \multirow{2}{*}{ Kategori } \\
\hline & & K1 & $\mathrm{K} 2$ & K3 & K4 & & \\
\hline Araucaria heterophylla & Cemara norfolk & 1 & 3 & 1 & 4 & 56 & Sedang \\
\hline Bauhinia purpurea & $\begin{array}{l}\text { Bunga kupu- } \\
\text { kupu }\end{array}$ & 2 & 4 & 2 & 2 & 63 & Baik \\
\hline Bismarckia nobilis & Bismark palm & 3 & 1 & 3 & 3 & 63 & Baik \\
\hline Coryota mitis & Palem ekor ikan & 1 & 1 & 1 & 3 & 38 & Buruk \\
\hline Cyrtostachys renda & Palem merah & 3 & 1 & 1 & 3 & 50 & Sedang \\
\hline Erythrina crista-galli & Dadap merah & 2 & 4 & 2 & 3 & 69 & Baik \\
\hline Felicium decipiens & Krei payung & 4 & 4 & 4 & 3 & 94 & $\begin{array}{l}\text { Sangat } \\
\text { baik }\end{array}$ \\
\hline Ficus elastica & Beringin karet & 2 & 3 & 2 & 3 & 63 & Baik \\
\hline Ficus lyrata & Biola cantik & 3 & 4 & 4 & 2 & 81 & $\begin{array}{l}\text { Sangat } \\
\text { baik }\end{array}$ \\
\hline Leucaena leucocephala & Lamtoro & 4 & 4 & 3 & 3 & 88 & $\begin{array}{l}\text { Sangat } \\
\text { baik }\end{array}$ \\
\hline Mangifera indica & Mangga & 3 & 4 & 3 & 2 & 75 & Baik \\
\hline Plumeria rubra & Kamboja & 2 & 4 & 1 & 1 & 50 & Sedang \\
\hline Polyalthia longifolia & Glodogan tiang & 1 & 2 & 4 & 2 & 56 & Sedang \\
\hline Pterocarpus indicus & Angsana & 4 & 4 & 2 & 2 & 75 & Baik \\
\hline Samanea saman & Trembesi & 4 & 4 & 4 & 2 & 88 & $\begin{array}{l}\text { Sangat } \\
\text { baik }\end{array}$ \\
\hline $\begin{array}{l}\text { Syzygium } \\
\text { campanulatum }\end{array}$ & Pucuk merah & 1 & 2 & 4 & 2 & 56 & Sedang \\
\hline Tabebuia chrysant & Tabebuia & 2 & 4 & 2 & 3 & 69 & Baik \\
\hline Wodyetia bifurcata & $\begin{array}{l}\text { Palem ekor } \\
\text { tupai }\end{array}$ & 4 & 1 & 1 & 3 & 56 & Sedang \\
\hline
\end{tabular}

Tabel 10 Hasil pengukuran suhu udara di Alun-alun

\begin{tabular}{|c|c|c|c|c|c|c|c|}
\hline \multirow{2}{*}{ Waktu } & \multicolumn{4}{|c|}{ Dalam RTH } & \multirow{2}{*}{$\begin{array}{c}\text { Rata-rata dalam } \\
\text { RTH }\left({ }^{\circ} \mathrm{C}\right)\end{array}$} & \multirow{2}{*}{$\begin{array}{l}\text { Rata-rata luar } \\
\text { RTH }\left({ }^{\circ} \mathrm{C}\right)\end{array}$} & \multirow{2}{*}{$\begin{array}{l}\text { Selisih } \\
\left({ }^{\circ} \mathrm{C}\right)\end{array}$} \\
\hline & $1\left({ }^{\circ} \mathrm{C}\right)$ & $2\left({ }^{\circ} \mathrm{C}\right)$ & $3\left({ }^{\circ} \mathrm{C}\right)$ & $4\left({ }^{\circ} \mathrm{C}\right)$ & & & \\
\hline Pagi & 27.5 & 29.0 & 26.5 & 27.3 & 27.6 & 29.9 & 2.4 \\
\hline Siang & 29.2 & 30.5 & 27.4 & 28.8 & 29.0 & 31.7 & 2.7 \\
\hline Sore & 28.0 & 28.7 & 27.4 & 28.0 & 28.0 & 29.6 & 1.6 \\
\hline Rata-rata & 28.2 & 29.4 & 27.1 & 28.0 & 28.2 & 30.4 & 2.2 \\
\hline Ket & $\begin{array}{l}\text { li atas } r \\
\text { li atas } r\end{array}$ & imput ta & gan na & $\begin{array}{l}\text { gan } \\
\text { ngan }\end{array}$ & $\begin{array}{l}\text { 2: di atas pe } \\
\text { 4: di atas pe }\end{array}$ & an dengan na & \\
\hline
\end{tabular}

Suhu di atas perkerasan tanpa naungan mempunya rata-rata suhu tertinggi. Hal itu disebabkan perkerasan menerima panas secara langsung dan mengalami konduksi. Berbeda dengan perkerasan, rumput tanpa naungan juga mengalami kenaikan suhu permukaan namun rumput dapat mengabsorbsi panas. 
Perbedaan suhu dalam penerimaan panas di berbagai landcover ini selaras dengan penelitian sebelumnya di mana perkerasan memiliki suhu tertinggi, diteruskan oleh area berumput, kemudian area pepohonan yang memiliki suhu terendah (Yan dan Li 2015). Suhu di luar Alun-alun tinggi karena pengukuran dilakukan di trotoar jalan dan tanpa adanya tanaman penaung.

Taman Kota didominasi oleh tanaman berkategori baik yang terdiri dari tiga jenis pohon hasil penilaian (Tabel 11), yaitu dadap merah (Erythrina crista-galli), kimeng (Ficus microcarpa), dan tabebuia (Tabebuia chrysant). Tanaman sedang turut mendominasi dengan persentase $33 \%$ dari total individu. Tanaman berkategori sangat baik meskipun hanya terdiri dari dua jenis pohon cukup memberikan bayangan yang luas karena bertajuk lebar.

Tabel 11 Penilaian aspek fungsi modifikasi suhu di Taman Kota

\begin{tabular}{|c|c|c|c|c|c|c|c|}
\hline \multirow{2}{*}{$\frac{}{y}$ Nama ilmiah } & \multirow{2}{*}{ Nama lokal } & \multicolumn{4}{|c|}{$\begin{array}{l}\text { Kriteria fungsi modifikasi } \\
\text { suhu }\end{array}$} & \multirow{2}{*}{$\begin{array}{c}\text { Skor } \\
(\%)\end{array}$} & \multirow{2}{*}{ Kategori } \\
\hline & & $\mathrm{K} 1$ & $\mathrm{~K} 2$ & K3 & $\mathrm{K} 4$ & & \\
\hline Cyrtostachys renda & Palem merah & 3 & 1 & 1 & 3 & 50 & Sedang \\
\hline $\begin{array}{l}\text { Erythrina crista- } \\
\text { galli }\end{array}$ & Dadap merah & 2 & 4 & 2 & 3 & 69 & Baik \\
\hline Felicium decipiens & Krei payung & 4 & 4 & 4 & 3 & 94 & $\begin{array}{l}\text { Sangat } \\
\text { baik }\end{array}$ \\
\hline Ficus microcarpa & Kimeng & 2 & 2 & 3 & 3 & 63 & Baik \\
\hline $\begin{array}{l}\text { Leucaena } \\
\text { leucocephala }\end{array}$ & Lamtoro & 4 & 4 & 3 & 3 & 88 & $\begin{array}{l}\text { Sangat } \\
\text { baik }\end{array}$ \\
\hline $\begin{array}{l}\text { Polyalthia } \\
\text { Iongifolia }\end{array}$ & Glodogan tiang & 1 & 2 & 4 & 2 & 56 & Sedang \\
\hline Tabebuia chrysant & Tabebuia & 2 & 4 & 2 & 3 & 69 & Baik \\
\hline Terminalia mantaly & Ketapang kencana & 3 & 2 & 2 & 1 & 50 & Sedang \\
\hline
\end{tabular}

Tanaman telah tersebar merata namun kerapatan tajuk masih rendah sehingga fungsi modifikasi suhu belum optimal (Gambar 13). Pengunjung yang masih membutuhkan tanaman peneduh terutama di area parklet, dimana pengunjung biasa duduk. Area parklet dibentuk oleh beberapa planting box yang ditanami tanaman dengan fungsi estetika seperi palem merah (Cyrtostachys renda).

Ada juga planter box yang ditanami kimeng (Ficus microcarpa) namun beringin yang terkenal rimbun tidak berfungsi sebagai pemodifikasi suhu yang baik di Taman Kota karena rutin dipangkas untuk dijadikan tanaman estetika. Pemilihan dan penataan tanaman sangat penting sehingga tanaman tidak hanya memberi nilai estetika namun juga dapat memberi nilai fungsi yang baik. Area berumput telah ditanami beberapa tanaman berkategori baik menjadi kurang fungsional karena area berumput hanya dijadikan display.

Hasil pengukuran suhu udara di Taman Kota pada Tabel 12 memperlihatkan suhu pada titik di atas rumput dengan naungan merupakan yang terendah. Perbandingan suhu antar titik masih tidak jauh berbeda dengan kondisi di Alunalun namun suhu pada titik rumput dan perkerasan tanpa naungan di Taman Kota tidak berbeda jauh. Hal itu terjadi karena kondisi rumput yang belum sama suburnya dengan kondisi rumput di Alun-alun. 
(180.0

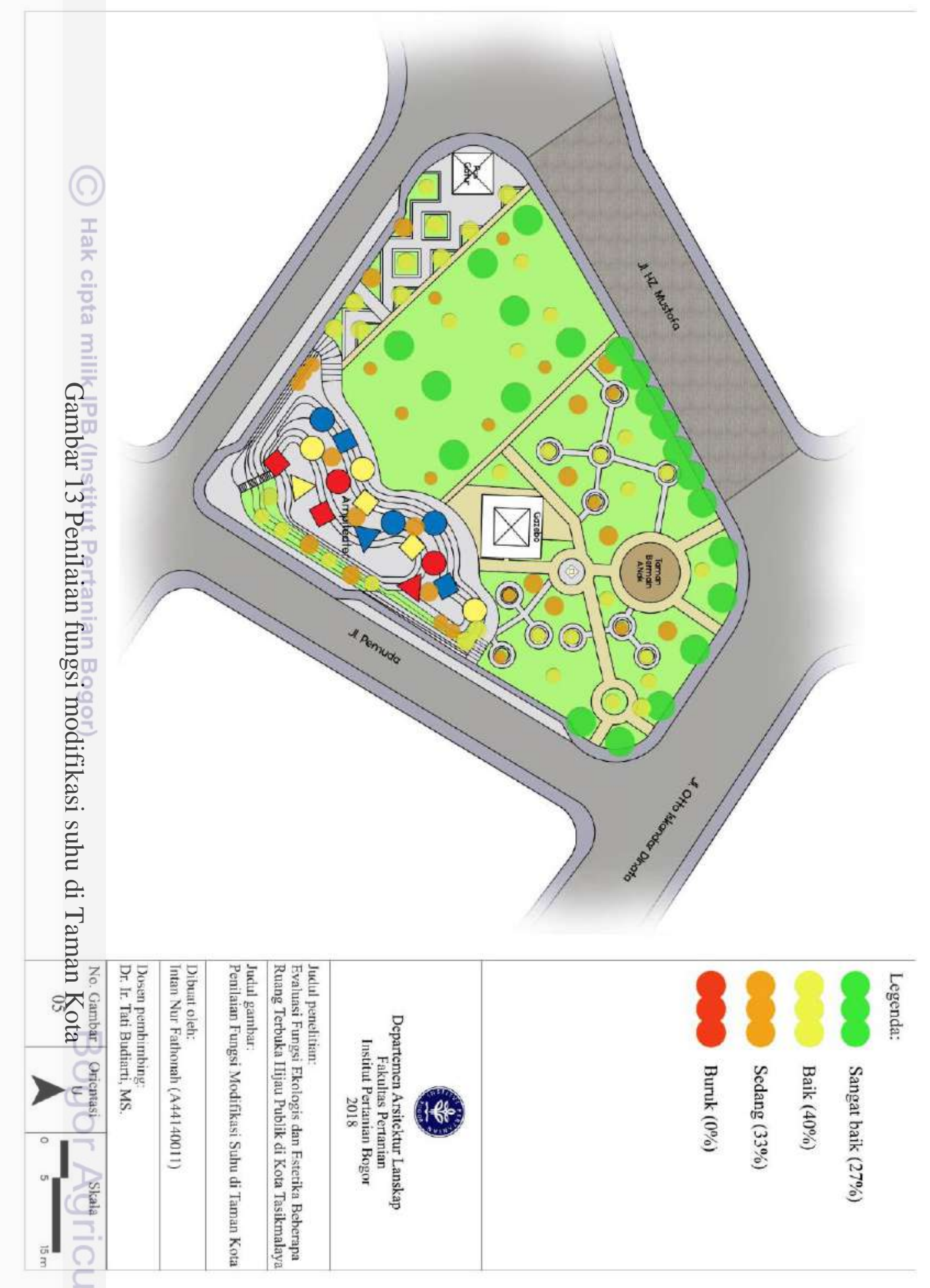


Tabel 12 Hasil pengukuran suhu udara di Taman Kota

\begin{tabular}{|c|c|c|c|c|c|c|c|}
\hline \multirow{2}{*}{ Waktu } & \multicolumn{4}{|c|}{ Dalam RTH } & \multirow{2}{*}{$\begin{array}{c}\text { Rata-rata } \\
\text { dalam } \\
\text { RTH } \\
\left({ }^{\circ} \mathrm{C}\right)\end{array}$} & \multirow{2}{*}{$\begin{array}{l}\text { Luar } \\
\text { RTH } \\
\left({ }^{\circ} \mathrm{C}\right)\end{array}$} & \multirow{2}{*}{$\begin{array}{c}\text { Selisih } \\
\left({ }^{\circ} \mathrm{C}\right)\end{array}$} \\
\hline & $1\left({ }^{\circ} \mathrm{C}\right)$ & $2\left({ }^{\circ} \mathrm{C}\right)$ & $3\left({ }^{\circ} \mathrm{C}\right)$ & $4\left({ }^{\circ} \mathrm{C}\right)$ & & & \\
\hline Pagi & 25.8 & 25.4 & 25.1 & 25.1 & 25.4 & 27.9 & 2.5 \\
\hline Siang & 31.0 & 31.5 & 29.0 & 30.0 & 30.4 & 32.0 & 1.6 \\
\hline Sore & 29.2 & 29.7 & 28.1 & 28.8 & 28.9 & 28.6 & 0.3 \\
\hline Rata-rata & 28.7 & 28.9 & 27.4 & 28.0 & 28.2 & 29.5 & 1.3 \\
\hline & atas ru & $\begin{array}{l}\text { tanpa } \\
\text { denga }\end{array}$ & $\begin{array}{l}\text { gan } \\
\text { ungan }\end{array}$ & 2: & s & denp & $\begin{array}{l}\text { gan } \\
\text { ungan }\end{array}$ \\
\hline
\end{tabular}

Sebagian besar tanaman di Kompleks Olahraga Wiradadaha dikategorikan sangat baik berdasarkan hasil penilaiannya terhadap fungsi modifikasi suhu, yaitu sebesar 52\% dari total individu (Tabel 13). Terdapat 10 tanaman yang dikategorikan sangat baik yang terdiri dari pepohonan bertajuk lebar yang mampu memberi bayangan yang luas. Sebanyak 18 jenis pohon dikategorikan baik namun hanya $32 \%$ dari total individu.

Tanaman di Kompleks Olahraga Wiradadaha tersebar merata sehingga hampir semua area telah ternaungi. Beberapa area tidak ternaungi penuh seperti area Taman Dadaha dan Taman Revolusi Mental. Area tersebut tidak ternaungi penuh karena kerapatan tajuk tanaman di area tersebut rendah dan tanaman masih berumur muda (Gambar 14).

Tabel 13 Penilaian aspek fungsi modifikasi suhu di Kompleks Olahraga Wiradadaha

\begin{tabular}{|c|c|c|c|c|c|c|c|}
\hline \multirow{2}{*}{ Nama ilmiah } & \multirow[t]{2}{*}{ Nama lokal } & \multicolumn{4}{|c|}{$\begin{array}{l}\text { Kriteria fungsi modifikasi } \\
\text { suhu }\end{array}$} & \multirow{2}{*}{$\begin{array}{l}\text { Skor } \\
(\%)\end{array}$} & \multirow[t]{2}{*}{ Kategori } \\
\hline & & K1 & $\mathrm{K} 2$ & K3 & K4 & & \\
\hline Acacia auriculiformis & Akasia & 4 & 4 & 2 & 2 & 75 & Baik \\
\hline Acacia longifolia & Akasia & 4 & 4 & 2 & 2 & 75 & Baik \\
\hline Alstonia scholaris & Pulai & 3 & 4 & 4 & 3 & 88 & $\begin{array}{l}\text { Sangat } \\
\text { baik }\end{array}$ \\
\hline Bauhinia purpurea & Bunga kupu-kupu & 2 & 4 & 2 & 2 & 63 & Baik \\
\hline Butia capitata & Jelly palm & 1 & 1 & 2 & 3 & 44 & Sedang \\
\hline Casuarina sp. & Cemara & 1 & 2 & 4 & 4 & 69 & Baik \\
\hline Cerbera odollam & Bintaro & 2 & 4 & 4 & 3 & 81 & $\begin{array}{l}\text { Sangat } \\
\text { baik }\end{array}$ \\
\hline Erythrina crista-galli & Dadap merah & 2 & 4 & 2 & 3 & 69 & Baik \\
\hline Felicium decipiens & Krei payung & 4 & 4 & 4 & 3 & 94 & $\begin{array}{l}\text { Sangat } \\
\text { baik }\end{array}$ \\
\hline Ficus benjamina & Beringin & 3 & 4 & 3 & 3 & 81 & $\begin{array}{l}\text { Sangat } \\
\text { baik }\end{array}$ \\
\hline Ficus elastica & Beringin karet & 2 & 3 & 2 & 3 & 63 & Baik \\
\hline Ficus lyrata & Biola cantik & 3 & 4 & 4 & 2 & 81 & $\begin{array}{l}\text { Sangat } \\
\text { baik }\end{array}$ \\
\hline $\begin{array}{l}\text { Leucaena } \\
\text { leucocephala }\end{array}$ & Lamtoro & 4 & 4 & 3 & 3 & 88 & $\begin{array}{l}\text { Sangat } \\
\text { baik }\end{array}$ \\
\hline
\end{tabular}


Tabel 13 Penilaian aspek fungsi modifikasi suhu di Kompleks Olahraga Wiradadaha (lanjutan)

\begin{tabular}{|c|c|c|c|c|c|c|c|}
\hline \multirow[t]{2}{*}{ Nama ilmiah } & \multirow[t]{2}{*}{ Nama lokal } & \multicolumn{4}{|c|}{$\begin{array}{c}\text { Kriteria fungsi modifikasi } \\
\text { suhu }\end{array}$} & \multirow{2}{*}{$\begin{array}{l}\text { Skor } \\
(\%)\end{array}$} & \multirow[t]{2}{*}{ Kategor } \\
\hline & & K1 & $\mathrm{K} 2$ & K3 & K4 & & \\
\hline Mangifera indica & Mangga & 3 & 4 & 3 & 2 & 75 & Baik \\
\hline Manilkara kaukii & Sawo kecik & 2 & 3 & 2 & 3 & 63 & Baik \\
\hline Maniltoa grandiflora & Pohon sapu tangan & 3 & 4 & 3 & 2 & 75 & Baik \\
\hline Mimusoph elengi $L$. & Tanjung & 3 & 4 & 2 & 2 & 69 & Baik \\
\hline Morinda citrifolia $L$. & Mengkudu & 2 & 2 & 3 & 2 & 56 & Sedang \\
\hline Muntingi calabura & Kersen & 2 & 4 & 4 & 3 & 81 & $\begin{array}{l}\text { Sangat } \\
\text { baik }\end{array}$ \\
\hline Ochroma pyramidale & Balsa & 4 & 2 & 2 & 1 & 56 & Sedang \\
\hline Plumeria rubra & Kamboja & 2 & 4 & 1 & 1 & 50 & Sedang \\
\hline Polyalthia fragrans & Glodogan bulat & 3 & 4 & 2 & 2 & 69 & Baik \\
\hline Polyalthia longifolia & Glodogan tiang & 1 & 2 & 4 & 2 & 56 & Sedang \\
\hline Pometia pinnata & Matoa & 2 & 2 & 3 & 3 & 63 & Baik \\
\hline Psidium guajava & Jambu & 3 & 2 & 2 & 3 & 63 & Baik \\
\hline Pterocapus indicus & Angsana & 4 & 4 & 2 & 2 & 75 & Baik \\
\hline Roystone regia & Palem raja & 4 & 1 & 1 & 2 & 50 & Sedang \\
\hline Samanea saman & Trembesi & 4 & 4 & 4 & 2 & 88 & $\begin{array}{l}\text { Sangat } \\
\text { baik }\end{array}$ \\
\hline Schleichera oleosa & Kesambi & 3 & 4 & 2 & 2 & 69 & Baik \\
\hline Sennasiamea & Johar & 4 & 4 & 3 & 2 & 81 & $\begin{array}{l}\text { Sangat } \\
\text { baik }\end{array}$ \\
\hline Switenia mahogani & Mahoni & 3 & 4 & 3 & 3 & 81 & $\begin{array}{l}\text { Sangat } \\
\text { baik }\end{array}$ \\
\hline $\begin{array}{l}\text { Syzygium } \\
\text { campanulatum }\end{array}$ & Pucuk merah & 1 & 2 & 4 & 2 & 56 & Sedang \\
\hline Tabebuia chrysant & Tabebuia & 2 & 4 & 2 & 3 & 69 & Baik \\
\hline Terminalia catappa & Ketapang & 4 & 3 & 2 & 3 & 75 & Baik \\
\hline Terminalia mantaly & Ketapang kencana & 3 & 3 & 2 & 2 & 63 & Baik \\
\hline Wodyetia bifurcata & Palem ekor tupai & 4 & 1 & 1 & 3 & 56 & Sedang \\
\hline
\end{tabular}

Berdasarkan hasil pengukuran suhu udara di Kompleks Olahraga Wiradadaha, rata-rata suhu udara di atas perkerasan dengan naungan merupakan yang terendah (Tabel 14). Hal itu berbeda dengan kondisi di Alun-alun dan Taman Kota di mana suhu terendah berada di titik atas rumput dengan naungan. Kondisi yang mendukung rendahnya suhu di perkerasan dengan naungan yaitu penataan pepohonan di Kompleks Olahraga Wiradadaha yang didominasi oleh penanaman tanaman secara kelompok dengan kerapatan yang tinggi. Menurut Abreu-Harbich, Labaki, dan Matzarakis (2015), sekelompok tanaman lebih baik dalam memodifikasi suhu dibandingkan pohon individu. Kompleks Olahraga Wiradadaha juga didominasi oleh tanaman berkategori sangat baik dalam modifikasi suhu menjadi nilai tambah dalam peran ekologisnya sebagai pemodifikasi suhu. Hal lain yang mempengaruhi kondisi tersebut yaitu suhu dipengaruhi oleh sifat perkerasan yang memiliki kecepatan yang tinggi dalam perubahan suhu dibandingkan tanaman (Effendy, Bey, Zain, dan Santosa 2006). 
6

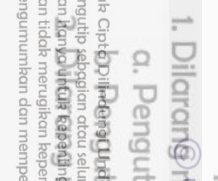

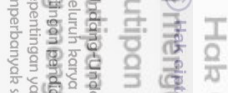

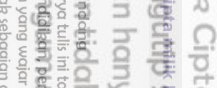

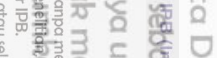

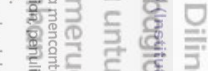

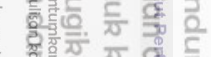

촌.

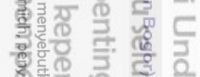

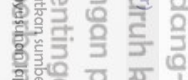

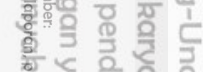

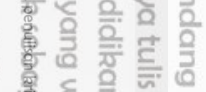

魷.

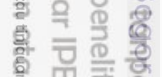

高告高

할

竞

खू

직

童

言

을

零

궁

这

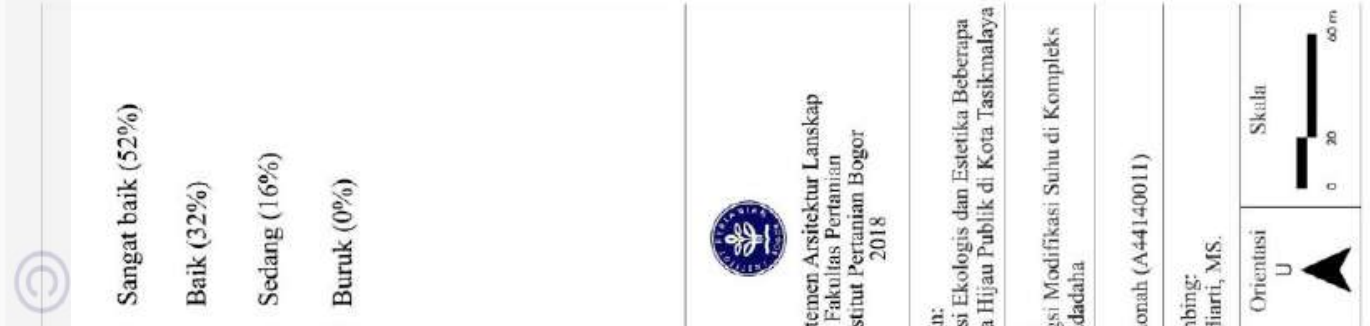

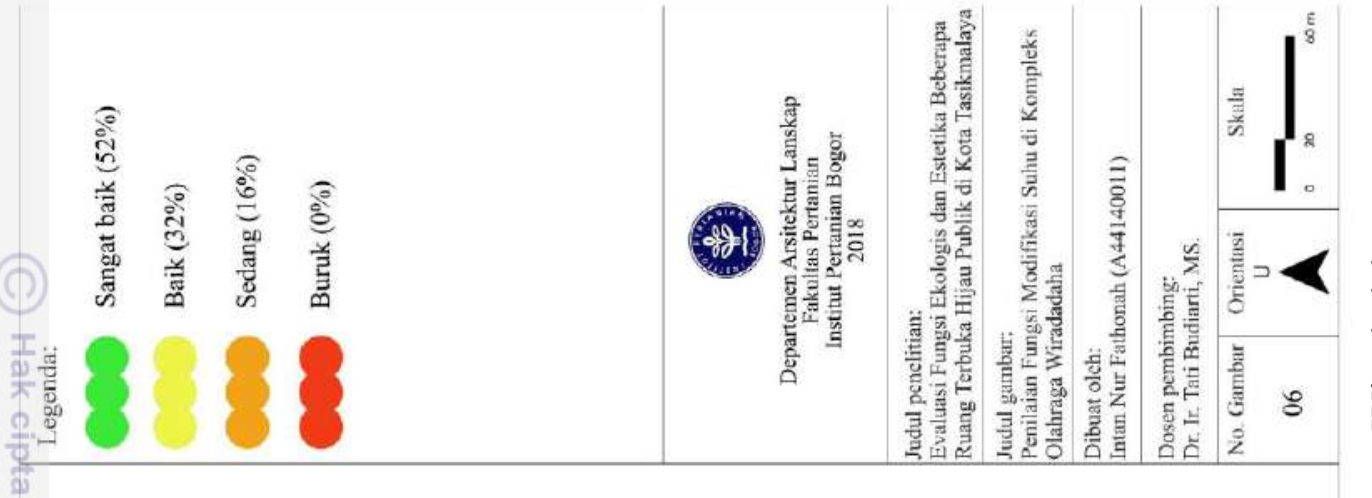

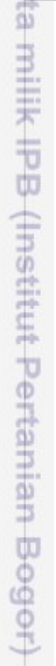

0

疍

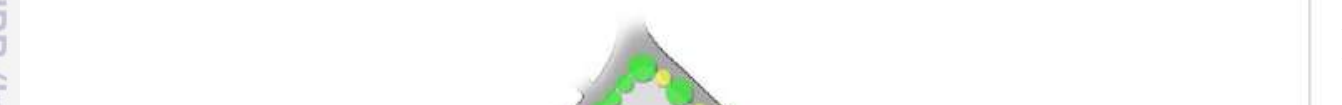

은 
Suhu udara di luar tapak Kompleks Olahraga Wiradadaha cenderung tidak setinggi di luar tapak Alun-alun dan Taman Kota. Area di luar tapak Kompleks Olahraga Wiradadaha masih rimbun, terutama di daerah Utara dan Selatan Kompleks Olahraga Wiradadaha. Hal itu menyebabkan selisih suhu antara dalam dan luar RTH hanya sebesar $0.7^{\circ} \mathrm{C}$.

Tabel 14 Hasil pengukuran suhu udara di Kompleks Olahraga Wiradadaha

\begin{tabular}{|c|c|c|c|c|c|c|c|}
\hline \multirow{2}{*}{ Waktu } & \multicolumn{4}{|c|}{ Dalam RTH } & \multirow{2}{*}{$\begin{array}{c}\text { Rata-rata } \\
\text { dalam } \\
\text { RTH } \\
\left({ }^{\circ} \mathrm{C}\right)\end{array}$} & \multirow{2}{*}{$\begin{array}{c}\text { Rata-rata } \\
\text { luar } \\
\text { RTH } \\
\left({ }^{\circ} \mathrm{C}\right) \\
\end{array}$} & \multirow{2}{*}{$\begin{array}{l}\text { Selisih } \\
\left({ }^{\circ} \mathrm{C}\right)\end{array}$} \\
\hline & $1\left({ }^{\circ} \mathrm{C}\right)$ & $2\left({ }^{\circ} \mathrm{C}\right)$ & $3\left({ }^{\circ} \mathrm{C}\right)$ & $4\left({ }^{\circ} \mathrm{C}\right)$ & & & \\
\hline Pagi $\underline{\Omega}$ & 25.8 & 25.8 & 25.2 & 24.8 & 25.4 & 26.0 & 0.6 \\
\hline Siang & 30.2 & 29.9 & 28.0 & 27.6 & 28.9 & 30.3 & 1.4 \\
\hline Sore 3 & 28.7 & 28.4 & 27.9 & 27.9 & 28.3 & 28.3 & 0.1 \\
\hline Rata-rāta & 28.3 & 28.0 & 27.1 & 26.8 & 27.5 & 28.2 & 0.7 \\
\hline
\end{tabular}

Ket: $\bar{\nabla}$ 1: di atas rumput tanpa naungan $\quad$ 2: di atas perkerasan tanpa naungan 3: di atas rumput dengan naungan 4: di atas perkerasan dengan naungan

Hasil penilaian keseluruhan menunjukkan bahwa Kompleks Olahraga Wiradadaha merupakan RTH yang terbaik dalam memodifikasi suhu. Terlepas dari lebih Juasnya area Kompleks Olahraga Wiradadaha, Kompleks Olahraga Wiradadaha memang didominasi oleh tanaman berkategori sangat baik dalam modifikasi suhu (Tabel 15). Penilaian tersebut sejalan dengan hasil pengukuran suhu udara yang menunjukkan bahwa rata-rata suhu udara di Kompleks Olahraga Wiradadaha terendah yaitu sebesar $27.5^{\circ} \mathrm{C}$ dan masih dalam rentang suhu ideal pada kisaran $27-28{ }^{\circ} \mathrm{C}$ (Laurie 1986). Alun-alun dan Taman Kota memiliki suhu yang sedikit melebihi rentang tersebut.

Tabel 15 Persentase penilaian tanaman fungsi modifikasi suhu

\begin{tabular}{clcccccc}
\hline Lokasi & Kategori & $\begin{array}{c}\text { Jumlah } \\
\text { jenis }\end{array}$ & $\begin{array}{c}\text { Jumlah } \\
\text { individu }\end{array}$ & $\begin{array}{c}\text { Persentase } \\
\text { terhadap } \\
\text { total jenis } \\
(\%)\end{array}$ & $\begin{array}{c}\text { Persentase } \\
\text { terhadap } \\
\text { total } \\
\text { individu } \\
(\%)\end{array}$ & Skor & Kategori \\
\hline & Sangat baik & 4 & 32 & 22 & 15 & & \\
Alun-alun & Baik & 7 & 83 & 39 & 40 & 270 & Sedang \\
& Sedang & 6 & 90 & 33 & 44 & & \\
Buruk & 1 & 2 & 6 & 1 & & \\
Taman Kota & Sangat baik & 3 & 44 & 38 & 27 & & \\
Bompleks & Sedang & 3 & 16 & 25 & 40 & 293 & Sedang \\
Olahraga & Buruk & 0 & 0 & 0 & 0 & & \\
Wiradadaha & Sangat baik & 10 & 451 & 27 & 52 & & \\
& Sedang & 18 & 280 & 49 & 32 & 336 & Baik \\
& Buruk & 0 & 139 & 22 & 16 & & \\
\hline
\end{tabular}


Tabel 16 Rata-rata suhu udara Alun-alun, Taman Kota, dan Kompleks Olahraga Wiradadaha

\begin{tabular}{|c|c|c|c|c|c|c|c|}
\hline \multirow[b]{2}{*}{ Lokasi penelitian } & \multicolumn{4}{|c|}{ Dalam RTH } & \multirow[b]{2}{*}{$\begin{array}{l}\text { Rata-rata } \\
\text { dalam } \\
\text { RTH }\left({ }^{\circ} \mathrm{C}\right)\end{array}$} & \multirow[b]{2}{*}{$\begin{array}{l}\text { Luar } \\
\text { RTH } \\
\left({ }^{\circ} \mathrm{C}\right)\end{array}$} & \multirow[b]{2}{*}{$\begin{array}{l}\text { Selisih } \\
\left({ }^{\circ} \mathrm{C}\right)\end{array}$} \\
\hline & $\begin{array}{l}\mathrm{P} 1 * \\
\left({ }^{\circ} \mathrm{C}\right)\end{array}$ & $\begin{array}{l}\mathrm{P} 2 * \\
\left({ }^{\circ} \mathrm{C}\right)\end{array}$ & $\begin{array}{l}\mathrm{P} 3 * \\
\left({ }^{\circ} \mathrm{C}\right)\end{array}$ & $\begin{array}{l}\mathrm{P} 4 * \\
\left({ }^{\circ} \mathrm{C}\right)\end{array}$ & & & \\
\hline Alun-alun & 28.2 & 29.4 & 27.1 & 28.0 & 28.2 & 30.4 & 2.2 \\
\hline Taman Kota & 28.7 & 28.9 & 27.4 & 28.0 & 28.2 & 29.5 & 1.3 \\
\hline $\begin{array}{l}\text { Kompleks Olahraga } \\
\text { Wiradadaha }\end{array}$ & 28.3 & 28.0 & 27.1 & 26.8 & 27.5 & 28.2 & 0.7 \\
\hline
\end{tabular}

* P1, P2, P3, dan P4 merupakan rata-rata data dari pengulangan waktu di 3 titik dalam RTH Ket: $\quad$ P1: di atas rumput tanpa naungan $\quad$ P2: di atas perkerasan tanpa naungan P3: di atas rumput dengan naungan $\quad$ P4: di atas perkerasan dengan naungan

Persepsi responden terhadap suhu udara di Alun-alun, Taman Kota, dan Kompleks Olahraga Dadaha sesuai dengan hasil penilaian dan analisis yang dilakukan (Gambar 15). Responden sebanyak 47\% menilai bahwa Kompleks Olahraga Wiradada dirasakan sejuk sedangkan responden di Alun-alun yang menilai sejuk sebesar 40\%. Taman Kota dinilai memiliki yang kondisi suhu sedang oleh mayoritas responden dengan peresntase $53 \%$.

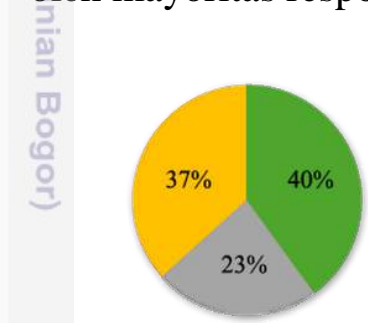

(a)

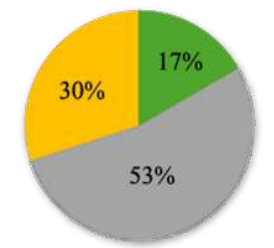

(b)

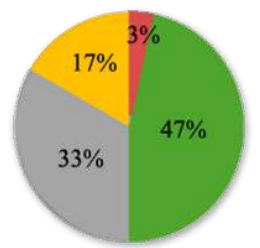

(c)

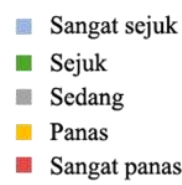

- Sangat panas

Gambar 15 Persentase persepsi responden tentang suhu udara di (a) Alun-alun, (b) Taman Kota, dan (c) Kompleks Olahraga Wiradadaha

\section{Fungsi kontrol kelembaban udara}

Salah satu faktor pembentuk kenyaman thermal selain suhu yaitu kelembaban. Kelembaban merupakan jumlah kandungan uap air dalam udara. Kelembaban yang terlalu tinggi maupun terlalu rendah tidak memberikan kenyamanan thermal yang optimal. Menurut Laurie (1986) kelembaban optimal adalah pada kisaran 40-75\%. Tanaman sebagai kontrol kelembaban udara mengatur kandungan uap air di udara dengan melakukan evapotranspirasi. Berikut adalah kriteria tanaman dengan fungsi kontrol kelembaban udara yang baik:

$\mathrm{K} 1=$ Bentuk tajuk bulat dan bulat terbuka (Femy 2014)

K2 = Berdaun jarum atau kasar (Grey dan Deneke 1978)

K3 = Tekstur batang kasar (Grey dan Deneke 1978)

K4 = Jumlah daun banyak (Carpenter et al. 1975) 
Penilain tanaman di setiap lokasi penelitian terhadap fungsi kontrol kelembaban berdasarkan keempat kriteria tersebut diuraikan dalam masing-masing Tabel 17, 19, dan 20.

Tabel 17 Penilaian aspek fungsi kontrol kelembaban udara di Alun-alun

\begin{tabular}{|c|c|c|c|c|c|c|c|}
\hline \multirow{2}{*}{ Nama ilmiah } & \multirow{2}{*}{ Nama lokal } & \multicolumn{4}{|c|}{$\begin{array}{c}\text { Kriteria fungsi kontrol } \\
\text { kelembaban udara }\end{array}$} & \multirow{2}{*}{$\begin{array}{l}\text { Skor } \\
(\%)\end{array}$} & \multirow{2}{*}{ Kategori } \\
\hline & & $\mathrm{K} 1$ & K2 & K3 & K4 & & \\
\hline $\begin{array}{l}\text { Araucaria } \\
\text { heterophylla }\end{array}$ & $\begin{array}{l}\text { Cemara } \\
\text { norfolk }\end{array}$ & 2 & 4 & 4 & 2 & 75 & Baik \\
\hline Bauhinia purpurea & $\begin{array}{l}\text { Bunga kupu- } \\
\text { kupu }\end{array}$ & 3 & 3 & 3 & 2 & 69 & Baik \\
\hline Bismarckia nobilis & Bismark palm & 1 & 2 & 4 & 1 & 50 & Sedang \\
\hline Coryota mitis & $\begin{array}{l}\text { Palem ekor } \\
\text { ikan }\end{array}$ & 1 & 2 & 1 & 1 & 31 & Buruk \\
\hline Cyrtostachys renda & Palem merah & 1 & 2 & 1 & 1 & 31 & Buruk \\
\hline Erythrina crista-galli & Dadap merah & 3 & 1 & 3 & 2 & 56 & Sedang \\
\hline Felicium decipiens & Krei payung & 3 & 1 & 4 & 3 & 69 & Baik \\
\hline Ficus élastica & Beringin karet & 4 & 1 & 2 & 3 & 63 & Baik \\
\hline Ficus tyrata & Biola cantik & 4 & 1 & 2 & 4 & 69 & Baik \\
\hline $\begin{array}{l}\text { Leисаёna } \\
\text { leucocephala }\end{array}$ & Lamtoro & 3 & 2 & 4 & 3 & 75 & Baik \\
\hline Mangifera indica & Mangga & 4 & 1 & 4 & 3 & 75 & Baik \\
\hline Plumeria rubra & Kamboja & 3 & 1 & 2 & 2 & 50 & Sedang \\
\hline Polyalthia longifolia & $\begin{array}{l}\text { Glodogan } \\
\text { tiang }\end{array}$ & 3 & 1 & 2 & 3 & 56 & Sedang \\
\hline Pterocarpus indicus & Angsana & 3 & 2 & 4 & 3 & 75 & Baik \\
\hline Samanea saman & Trembesi & 3 & 1 & 4 & 4 & 75 & Baik \\
\hline $\begin{array}{l}\text { Syzygium } \\
\text { campanulatum }\end{array}$ & Pucuk merah & 4 & 1 & 2 & 4 & 69 & Baik \\
\hline Tabebuia chrysant & Tabebuia & 3 & 3 & 3 & 2 & 69 & Baik \\
\hline Wodyetia bifurcata & $\begin{array}{l}\text { Palem ekor } \\
\text { tupai }\end{array}$ & 1 & 2 & 1 & 1 & 31 & Buruk \\
\hline
\end{tabular}

Alun-alun didominasi oleh tanaman berkategori baik dalam fungsi kontrol kelembaban. Persentase total individu pohon berkategori baik sebesar 52\% mendominasi dan tersebar merata di Alun-alun (Gambar 16). Beberapa jenis pohon yang dikategorikan sedang yaitu palem bismark (Bismarckia nobilis), dadap merah (Erythrina crista-galli), kamboja (Plumeria rubra), dan glodogan tiang (Polyalthia longifolia) karena masih belum memenuhi pada beberapa kriteria yang berbeda. Palem merah (Cyrtostachys renda), palem ekor ikan (Coryota mitis), dan palem ekor tupai (Wodyetia bifurcate) dikategorikan buruk dalam kelembaban udara karena rata-rata memiliki tajuk payung yang buruk dalam mempertahankan kelembaban di bawah tajuknya.

Berdasarkan hasil pengukuran kelembaban, titik di atas rumput dalam Tabel 18 memiliki kelembaban lebih tinggi dibandingkan di atas perkerasan. Rumput sebagai salah satu jenis tanaman penutup tanah mereduksi panas dengan absorbsi dan evaporasi sehingga kandungan uap air di atasnya lebih tinggi. 
(16)

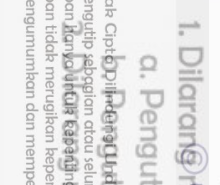

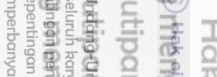

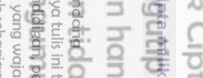

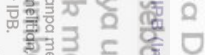

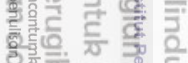

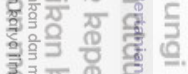

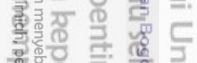

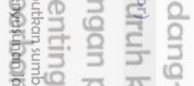

응

残言

है

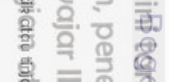

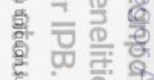

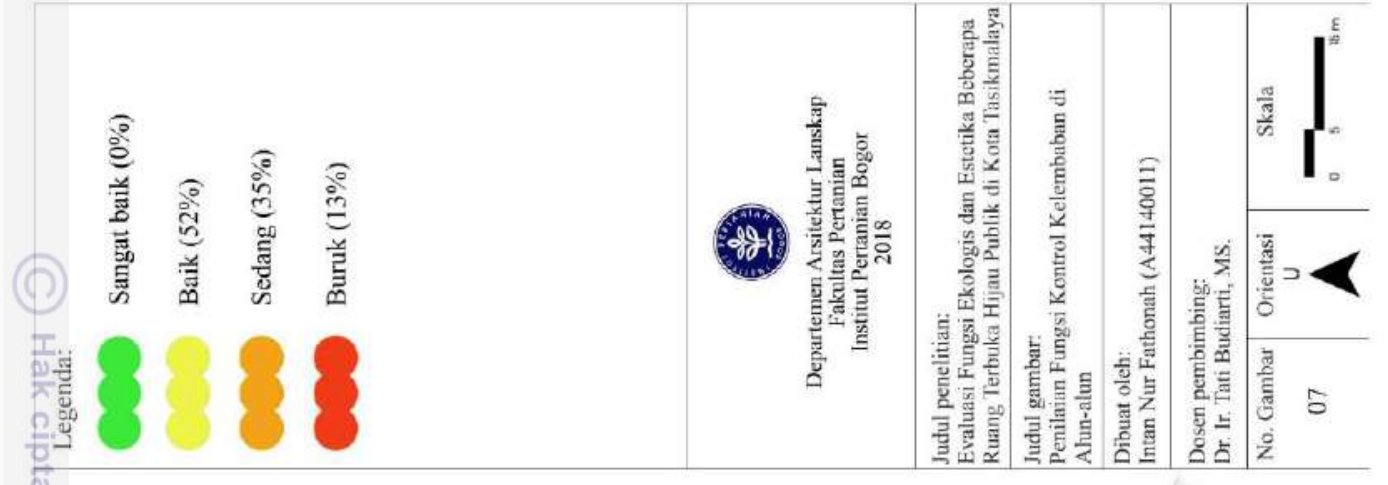

志

홍

高变

즐 월
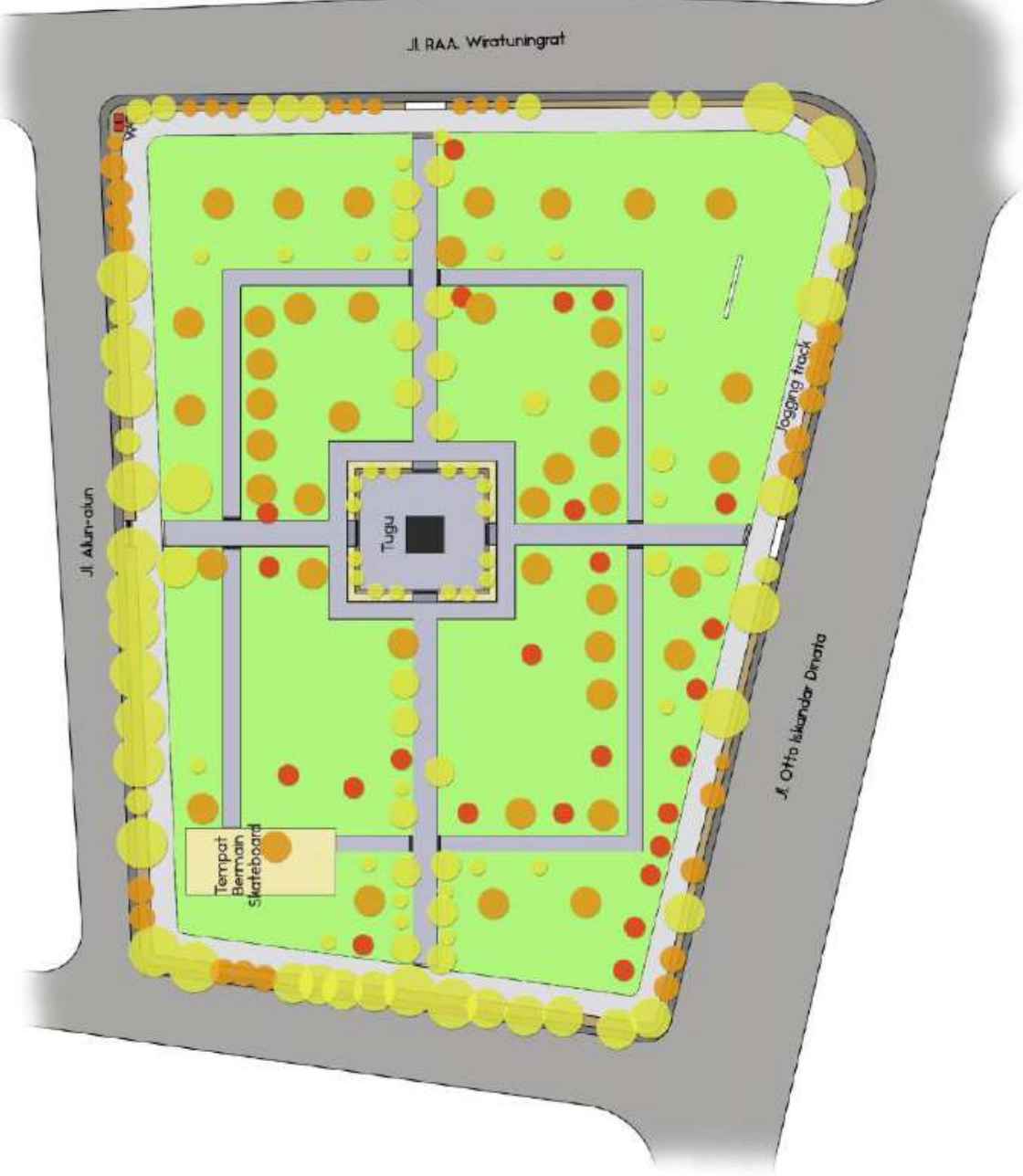

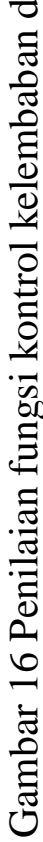


Kelembaban di atas rumput tanpa naungan cenderung lebih tinggi dibandingkan kelembaban di atas rumput dengan naungan karena pada titik di atas rumput tanpa naungan, panas yang diterima permukaan lebih tinggi sehingga kandungan uap air yang dikeluarkan juga lebih tinggi.

Hasil pengukuran kelembaban udara di Alun-alun sejalan dengan hasil penilaian tanaman terhadap fungsi kontrol kelembaban. Alun-alun didominasi oleh tanaman berkategori baik. Hasil pengukuran pun menunjukkan kelembaban udara masih berada pada kisaran normal.

Tabel 18 Hasil pengukuran kelembaban udara di Alun-Alun

\begin{tabular}{|c|c|c|c|c|c|c|c|}
\hline \multirow{2}{*}{ Waktu } & \multicolumn{4}{|c|}{ Dalam RTH } & \multirow{2}{*}{$\begin{array}{c}\text { Rata-rata } \\
\text { dalam RTH } \\
(\%)\end{array}$} & \multirow{2}{*}{$\begin{array}{c}\text { Rata-rata } \\
\text { luar RTH } \\
(\%) \\
\end{array}$} & \multirow{2}{*}{$\begin{array}{c}\text { Selisih } \\
(\%)\end{array}$} \\
\hline & $1(\%)$ & $2(\%)$ & $3(\%)$ & $4(\%)$ & & & \\
\hline Pagi 3 & 68 & 59 & 66 & 62 & 64 & 46 & 18 \\
\hline Siang & 68 & 53 & 67 & 57 & 61 & 51 & 10 \\
\hline Sore & 67 & 63 & 68 & 64 & 65 & 56 & 9 \\
\hline Rata-rata & 68 & 58 & 67 & 61 & 63 & 51 & 12 \\
\hline
\end{tabular}

Ket: 1: di atas rumput tanpa naungan $\quad 2:$ di atas perkerasan tanpa naungan
3: di atas rumput dengan naungan
4: di atas perkerasan dengan naungan

Penilaian tanaman dalam aspek fungsi kontrol kelembaban udara di Taman Kota pada Tabel 19 menunjukkan sebagian besar jenis tanaman dikategorikan baik. Persentase tanaman yang dikategorikan baik terhadap jumlah total individu yaitu $47 \%$ sedangkan yang dikategorikan sedang mencapai $42 \%$. Tanaman berkategori baik maupun sedang banyak tersebar di area parklet dan area berumput secara merata(Gambar 17).

Tabel 19 Penilaian aspek fungsi kontrol kelembaban udara di Taman Kota

\begin{tabular}{|c|c|c|c|c|c|c|c|}
\hline \multirow[t]{2}{*}{ Nama ilmiah } & \multirow[t]{2}{*}{ Nama lokal } & \multicolumn{4}{|c|}{$\begin{array}{c}\text { Kriteria fungsi kontrol kelembaban } \\
\text { udara }\end{array}$} & \multirow{2}{*}{$\begin{array}{l}\text { Skor } \\
(\%)\end{array}$} & \multirow[t]{2}{*}{ Kategor } \\
\hline & & $\mathrm{K} 1$ & $\mathrm{~K} 2$ & K3 & K4 & & \\
\hline Cyrtostachys renda & Palem merah & 1 & 2 & 1 & 1 & 31 & Buruk \\
\hline $\begin{array}{l}\text { Erythrina crista- } \\
\text { galli }\end{array}$ & Dadap merah & 3 & 1 & 3 & 2 & 56 & Sedang \\
\hline Felicium decipiens & Krei payung & 3 & 1 & 4 & 3 & 69 & Baik \\
\hline Ficus microcarpa & Kimeng & 2 & 1 & 2 & 3 & 50 & Sedang \\
\hline $\begin{array}{l}\text { Leucaena } \\
\text { leucocephala }\end{array}$ & Lamtoro & 3 & 2 & 4 & 3 & 75 & Baik \\
\hline $\begin{array}{l}\text { Polyalthia } \\
\text { longifolia }\end{array}$ & $\begin{array}{l}\text { Glodogan } \\
\text { tiang }\end{array}$ & 3 & 1 & 2 & 3 & 56 & Sedang \\
\hline Tabebuia chrysant & Tabebuia & 3 & 3 & 3 & 2 & 69 & Baik \\
\hline Terminalia mantaly & $\begin{array}{l}\text { Ketapang } \\
\text { kencana }\end{array}$ & 4 & 1 & 2 & 3 & 63 & Baik \\
\hline
\end{tabular}


6

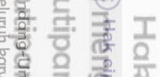

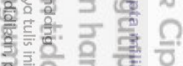
政

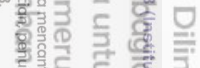

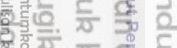

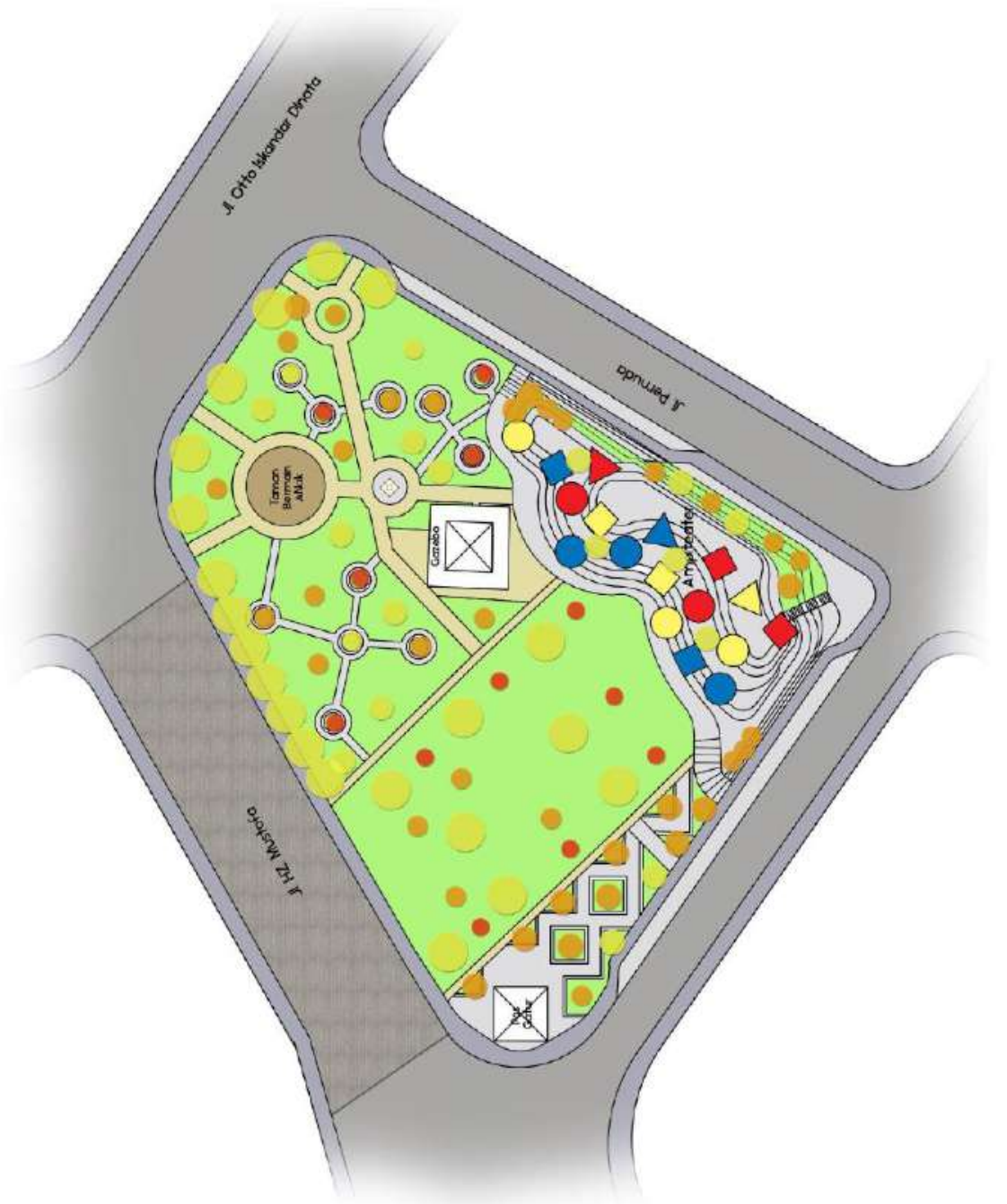


Hasil pengukuran kelembaban udara di Taman Kota menunjukkan bahwa titik di atas rumput dengan naungan memiliki kelembaban tertinggi (Tabel 20). Kelembaban udara di atas rumput tanpa naungan lebih rendah daripada dengan naungan, berbeda dengan kondisi di Alun-alun di mana kelembaban udara di atas rumput tanpa naungan cenderung lebih tinggi dibandingkan titik dengan naungannya.

Tabel 20 Hasil pengukuran kelembaban udara di Taman Kota

\begin{tabular}{|c|c|c|c|c|c|c|c|}
\hline \multirow{2}{*}{ Waktu } & \multicolumn{4}{|c|}{ Dalam RTH } & \multirow{2}{*}{$\begin{array}{c}\text { Rata-rata } \\
\text { dalam } \\
\text { RTH } \\
(\%)\end{array}$} & \multirow{2}{*}{$\begin{array}{c}\text { Luar } \\
\text { RTH } \\
(\%)\end{array}$} & \multirow{2}{*}{$\begin{array}{l}\text { Selisih } \\
(\%)\end{array}$} \\
\hline & $1(\%)$ & $2(\%)$ & $3(\%)$ & $4(\%)$ & & & \\
\hline Pagi 뭇 & 72.0 & 72.4 & 74.4 & 71.4 & 72.6 & 66.0 & 6.6 \\
\hline Siang $\Xi$ & 56.6 & 55.4 & 58.4 & 57.3 & 56.9 & 48.7 & 8.3 \\
\hline Sore $\equiv$ & 57.2 & 57.3 & 59.3 & 58.1 & 58.0 & 57.3 & 0.7 \\
\hline Rata-rata & 61.9 & 61.7 & 64.1 & 62.3 & 62.5 & 57.3 & 5.2 \\
\hline
\end{tabular}

Ket: 1: di atas rumput tanpa naungan

3: di atas rumput dengan naungan

2: di atas perkerasan tanpa naungan

4: di atas perkerasan dengan naungan

Menurut Saputro (2010), nilai kelembaban udara relatif dipengaruhi oleh berbagai faktor, salah satunya adalah tingkat ketersediaan bahan penguap. Taman Kota yang baru dibangun masih memiliki area berumput yang belum tumbuh sama suburnya dengan rumput di Alun-alun sehingga ketersediaan rumput sebagai bahan penguap masih rendah. Tanaman peneduh juga berfungsi sebagai penjaga kelembaban karena menahan kecepatan turbulensi angin yang dapat menurunkan kelembaban sehingga kelembaban di bawah tajuk pohon lebih stabil dibandingkan dengan kelembaban di atas titik tanpa naungan pohon.

Kompleks Olahraga Wiradadaha memiliki $82 \%$ dari total individu tanaman dikategorikan baik dalam fungsinya sebagai kontrol kelembaban udara sedangkan sebanyak $12 \%$ dari total individu dikategorikan sedang. Tanaman peneduh seperti krei payung (Felicium decipiens), biola cantik (Ficus lyrata), dan trembesi (Samanea saman) memiliki daun yang banyak dan tekstur kayu kasar. Pohon yang memiliki batang bertekstur kasar meningkatkan kelembaban dengan menjerap air saat presipitasi. Daun yang banyak membantu meningkatkan kelembaban dengan proses evapotranspirasi. Kedua kriteria ini meningkatkan kandungan air dalam udara di bawah tajuk tanaman-tanaman tersebut.

Tabel 21 Penilaian aspek fungsi kontrol kelembaban udara di Kompleks Olahraga Wiradadaha

\begin{tabular}{|c|c|c|c|c|c|c|c|}
\hline \multirow{2}{*}{ Nama ilmiah } & \multirow[t]{2}{*}{ Nama lokal } & \multicolumn{4}{|c|}{$\begin{array}{l}\text { Kriteria fungsi kontrol } \\
\text { kelembaban udara }\end{array}$} & \multirow{2}{*}{$\begin{array}{l}\text { Skor } \\
(\%)\end{array}$} & \multirow[t]{2}{*}{ Kategori } \\
\hline & & K1 & $\mathrm{K} 2$ & K3 & K4 & & \\
\hline Acacia auriculiformis & Akasia & 3 & 1 & 4 & 4 & 75 & Baik \\
\hline Acacialongifolia & Akasia & 3 & 1 & 4 & 4 & 75 & Baik \\
\hline Alstonia scholaris & Pulai & 4 & 1 & 3 & 4 & 75 & Baik \\
\hline Bauhinia purpurea & $\begin{array}{l}\text { Bunga kupu- } \\
\text { kupu }\end{array}$ & 3 & 3 & 3 & 3 & 75 & Baik \\
\hline
\end{tabular}


Tabel 21 Penilaian aspek fungsi kontrol kelembaban udara di Kompleks Olahraga Wiradadaha (lanjutan)

\begin{tabular}{|c|c|c|c|c|c|c|c|}
\hline \multirow[t]{2}{*}{ Nama ilmiah } & \multirow[t]{2}{*}{ Nama lokal } & \multicolumn{4}{|c|}{$\begin{array}{l}\text { Kriteria fungsi kontrol } \\
\text { kelembaban udara }\end{array}$} & \multirow{2}{*}{$\begin{array}{l}\text { Skor } \\
(\%)\end{array}$} & \multirow[t]{2}{*}{ Kategor } \\
\hline & & $\mathrm{K} 1$ & $\mathrm{~K} 2$ & K3 & K4 & & \\
\hline Butia capitata & Jelly palm & 1 & 2 & 1 & 1 & 31 & Buruk \\
\hline Casuarina sp. & Cemara & 2 & 4 & 4 & 2 & 75 & Baik \\
\hline Cerbera odollam & Bintaro & 4 & 1 & 3 & 4 & 75 & Baik \\
\hline Erythrina crista-galli & Dadap merah & 3 & 1 & 3 & 2 & 56 & Sedang \\
\hline Felicium decipiens & Krei payung & 3 & 1 & 4 & 3 & 69 & Baik \\
\hline Ficus benjamina & Beringin & 4 & 1 & 2 & 4 & 69 & Baik \\
\hline Ficus elastica & Beringin karet & 4 & 1 & 2 & 3 & 63 & Baik \\
\hline Ficus lyrata & Biola cantik & 4 & 1 & 2 & 4 & 69 & Baik \\
\hline Leucaena leucocephala & Lamtoro & 3 & 2 & 4 & 3 & 75 & Baik \\
\hline Mangifera indica & Mangga & 4 & 1 & 4 & 3 & 75 & Baik \\
\hline Manilkara kaukii & Sawo kecik & 4 & 1 & 3 & 3 & 69 & Baik \\
\hline Maniltoa grandiflora & $\begin{array}{l}\text { Pohon sapu } \\
\text { tangan }\end{array}$ & 4 & 1 & 3 & 4 & 75 & Baik \\
\hline Mimusoph elengi L. & Tanjung & 4 & 3 & 3 & 3 & 81 & $\begin{array}{l}\text { Sangat } \\
\text { baik }\end{array}$ \\
\hline Morinda citrifolia L. & Mengkudu & 2 & 1 & 2 & 3 & 50 & Sedang \\
\hline Muntingi calabura & Kersen & 3 & 3 & 1 & 3 & 63 & Baik \\
\hline Ochroma pyramidale & Balsa & 3 & 3 & 2 & 2 & 63 & Baik \\
\hline Plumeria rubra & Kamboja & 3 & 1 & 2 & 2 & 50 & Sedang \\
\hline Polyalthia fragrans & $\begin{array}{l}\text { Glodogan } \\
\text { bulat }\end{array}$ & 4 & 1 & 1 & 4 & 63 & Baik \\
\hline Polyalthia longifolia & $\begin{array}{l}\text { Glodogan } \\
\text { tiang }\end{array}$ & 3 & 1 & 2 & 4 & 63 & Baik \\
\hline Pometia pinnata & Matoa & 3 & 1 & 2 & 3 & 56 & Sedang \\
\hline Psidium guajava & Jambu & 3 & 1 & 2 & 3 & 56 & Sedang \\
\hline Pterocapus indicus & Angsana & 3 & 3 & 4 & 2 & 75 & Baik \\
\hline Roystone regia & Palem raja & 1 & 2 & 1 & 1 & 31 & Buruk \\
\hline Samanea saman & Trembesi & 3 & 1 & 4 & 4 & 75 & Baik \\
\hline Schleichera oleosa & Kesambi & 3 & 3 & 3 & 2 & 69 & Baik \\
\hline Senna siamea & Johar & 2 & 1 & 4 & 3 & 63 & Baik \\
\hline Switenia mahogani & Mahoni & 2 & 1 & 4 & 3 & 63 & Baik \\
\hline $\begin{array}{l}\text { Syzygium } \\
\text { campanulatum }\end{array}$ & Pucuk merah & 4 & 1 & 2 & 4 & 69 & Baik \\
\hline Tabebuia chrysant & Tabebuia & 3 & 3 & 3 & 2 & 69 & Baik \\
\hline Terminalia catappa & Ketapang & 4 & 1 & 2 & 2 & 56 & Sedang \\
\hline Terminalia mantaly & $\begin{array}{l}\text { Ketapang } \\
\text { kencana }\end{array}$ & 4 & 1 & 2 & 2 & 56 & Sedang \\
\hline Wodyetia bifurcata & $\begin{array}{l}\text { Palem ekor } \\
\text { tupai }\end{array}$ & 1 & 2 & 1 & 1 & 31 & Buruk \\
\hline
\end{tabular}

Tanaman berkategori baik tersebar merata di hampir seluruh area Kompleks Olahraga Wiradadaha (Gambar 18). Tanaman berkategori baik ini bahkan tumbuh rapat dibeberapa area seperti area kebugaran dan tempat bermain anak sehingga 
18

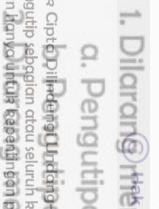

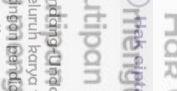

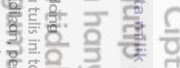

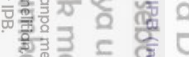

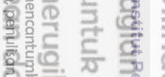

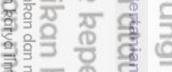

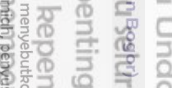

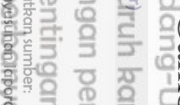

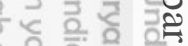

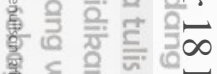

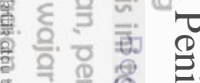

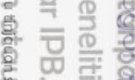

夏

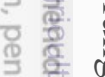

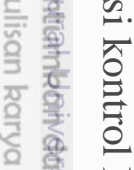

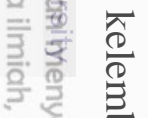

(C)

व

등

言

西

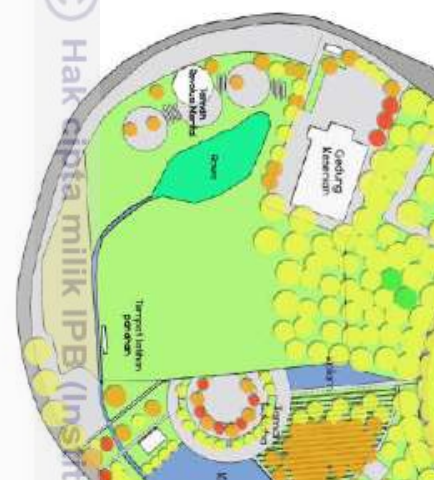

लिखिएल्लm ?
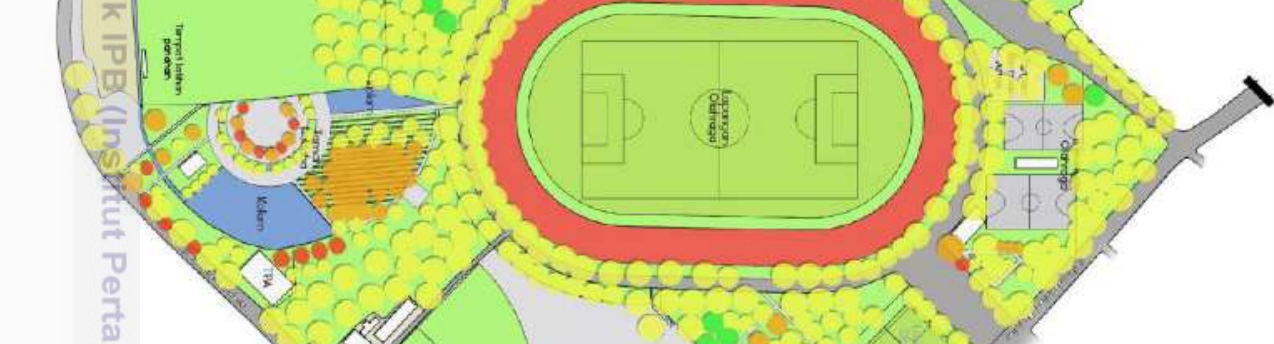

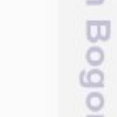


permukaan tanah ikut lembab. Bila dibiarkan tanpa perawatan yang baik, kelembaban di area tersebut dapat terlalu tinggi terutama ketika musim hujan. Tanaman berkategori sedang hanya terpusat di beberapa titik dan sebagian tersebar acak.

Hasil pengukuran kelembaban udara di Kompleks Olahraga Wiradadaha di setiap titiknya tidak menunjukkan perbedaan yang signifikan terutama di pagi dan sore hari. Menurut Handoko (1995) dalam Saputro (2010), kelembaban udara dipengaruhi oleh suhu udara namun tidak berlaku sebaliknya. Suhu udara pada pagi hari relatif rendah sehingga kelembaban cenderung tinggi di pagi hari. Nilai kelembaban udara berubah ketika suhu udara yang disebabkan radiasi matahari meningkat.

Titik di atas rumput (Tabel 22) cenderung lebih tinggi karena dipengaruhi oleh tingkat kesediaan bahan penguap yang dimiliki permukaan. Pepohonan dengan tajuk rapat menyebabkan titik dengan naungan dapat menjaga kandungan uap air udara di bawah tajuk karena sedikitnya aliran angin yang masuk. Selisih antara kelembaban di dalam dan di luar tapak cukup tinggi terutama di pagi dan siang hari. Selisih antara kelembaban di dalam dan di luar tapak pada sore hari lebih rendah karena intensitas radiasi matahari semakin rendah sehingga suhu di dalam dan luar tapak pun tidak berbeda jauh.

Tabel 22 Hasil pengukuran kelembaban udara di Kompleks Olahraga Wiradadaha

\begin{tabular}{|c|c|c|c|c|c|c|c|}
\hline \multirow{2}{*}{ Waktu } & \multicolumn{4}{|c|}{ Dalam RTH } & \multirow{2}{*}{$\begin{array}{c}\text { Rata-rata } \\
\text { dalam } \\
\text { RTH } \\
(\%) \\
\end{array}$} & \multirow{2}{*}{$\begin{array}{c}\text { Rata-rata } \\
\text { luar } \\
\text { RTH } \\
(\%) \\
\end{array}$} & \multirow{2}{*}{$\begin{array}{c}\text { Selisih } \\
(\%)\end{array}$} \\
\hline & $1(\%)$ & $2(\%)$ & $3(\%)$ & $4(\%)$ & & & \\
\hline Pagi & 77.9 & 74.8 & 76.9 & 77.3 & 76.7 & 69.0 & 7.7 \\
\hline Siang & 60.1 & 54.9 & 63.8 & 60.8 & 59.9 & 52.0 & 7.9 \\
\hline Sore & 60.0 & 59.7 & 61.4 & 59.9 & 60.3 & 57.0 & 3.2 \\
\hline Rata-rata & 66.0 & 63.1 & 67.4 & 66.0 & 65.6 & 59.3 & 6.3 \\
\hline Ket: & tas $r$ & denga & ngan & $\begin{array}{l}2: d \\
4: d\end{array}$ & perke & denga & ngan \\
\hline
\end{tabular}

Hasil penilaian keseluruhan tanaman dengan fungsi kontrol kelembaban udara menunjukkan bahwa Kompleks Olahraga Wiradadaha mendapatkan skor tertinggi dengan nilai 282 dan dalam kategori baik (Tabel 23). Hal itu selaras dengan hasil pengukuran kelembaban di mana Kompleks Olahraga Wiradadaha memiliki rata-rata kelembaban yang paling tinggi dan masih dalam kelembaban ideal menurut Laurie (1986). Berdasarkan hasil pengukuran, rata-rata kelembaban ketiga lokasi penelitian masih berada pada tingkat ideal yaitu pada kisaran 62.565.6\% (Tabel 24). Selisih nilai kelembaban udara di dalam dan di luar tapak tertinggi yaitu $12 \%$ yang berada di Alun-alun. Selisih yang tinggi terjadi di Alunalun karena Alun-alun berada di tengah kota yang dikelilingi oleh trotoar jalan dengan sedikit pepohonan rindang. Berbeda dengan Kompleks Olahraga Wiradada yang masih dikelilingi oleh pepohonan rindang dan fasilitas olahraga lain di luar Kompleks Olahraga Wiradadaha. 
Tabel 23 Persentase penilaian tanaman fungsi kontrol kelembaban udara

\begin{tabular}{clcccccc}
\hline Lokasi & Kategori & $\begin{array}{c}\text { Jumlah } \\
\text { Jenis }\end{array}$ & $\begin{array}{c}\text { Jumlah } \\
\text { Individu }\end{array}$ & $\begin{array}{c}\text { Persentase } \\
\text { terhadap } \\
\text { total jenis } \\
(\%)\end{array}$ & $\begin{array}{c}\text { Persentase } \\
\text { terhadap } \\
\text { total } \\
\text { individu } \\
(\%)\end{array}$ & Skor & Kategori \\
\hline & Sangat baik & 0 & 0 & 0 & 0 & & \\
Alun-alun & Baik & 11 & 108 & 61 & 52 & 239 & Baik \\
& Sedang & 4 & 72 & 22 & 35 & & \\
& Buruk & 3 & 27 & 17 & 13 & & \\
Taman. & Sangat baik & 0 & 0 & 0 & 0 & & \\
Kota & Baik & 5 & 62 & 63 & 47 & 236 & Baik \\
& Sedang & 2 & 18 & 25 & 42 & & \\
Kompleks & Buruk & 1 & 10 & 13 & 11 & & \\
Olahraga & Baik & 25 & 717 & 68 & 82 & 282 & Baik \\
Wirada- & Sedang & 7 & 104 & 19 & 12 & & \\
daha & Buruk & 3 & 33 & 8 & 4 & & \\
\hline
\end{tabular}

Tabel 24 Rata-rata kelembaban udara Alun-alun, Taman Kota, dan Kompleks Olahraga Wiradadaha

\begin{tabular}{|c|c|c|c|c|c|c|c|}
\hline \multirow{2}{*}{ 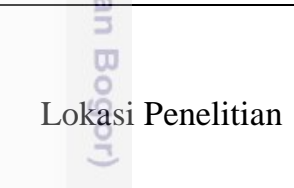 } & \multicolumn{4}{|c|}{ Dalam RTH } & \multirow[b]{2}{*}{$\begin{array}{l}\text { Rata-rata } \\
\text { dalam RTH } \\
\text { (\%) }\end{array}$} & \multirow[b]{2}{*}{$\begin{array}{l}\text { Luar } \\
\text { RTH } \\
(\%)\end{array}$} & \multirow[b]{2}{*}{$\begin{array}{c}\text { Selisih } \\
(\%)\end{array}$} \\
\hline & $\begin{array}{l}\mathrm{P} 1 * \\
(\%)\end{array}$ & $\begin{array}{l}\mathrm{P} 2 * \\
(\%)\end{array}$ & $\begin{array}{l}\mathrm{P} 3 * \\
(\%)\end{array}$ & $\begin{array}{l}\mathrm{P} 4 * \\
(\%)\end{array}$ & & & \\
\hline Alun-alun & 67 & 58 & 67 & 61 & 63 & 51 & 12 \\
\hline Taman Kota & 61.9 & 61.7 & 64.1 & 62.3 & 62.5 & 57.3 & 5.2 \\
\hline $\begin{array}{l}\text { Kompleks Olahraga } \\
\text { Wiradadaha }\end{array}$ & 66.0 & 63.1 & 67.4 & 66.0 & 65.6 & 59.3 & 6.3 \\
\hline
\end{tabular}

* P1, P2, P3, dan P4 merupakan rata-rata data dari pengulangan waktu di 3 titik dalam RTH Ket: P1: di atas rumput tanpa naungan $\quad$ P2: di atas perkerasan tanpa naungan P3: di atas rumput dengan naungan $\quad$ P4: di atas perkerasan dengan naungan

Persepsi responden dari setiap lokasi rata-rata menyatakan bahwa kelembaban udara berada pada tingkat sedang (Gambar 19). Sebanyak 17\%, 21\%, dan 20\% dari masing-masing lokasi: Alun-alun, Taman Kota, dan Kompleks Olahraga Wiradadaha, menyatakan bahwa lokasi berada pada tingkat kelembaban udara lembab. Hal tersebut sejalan dengan hasil pengukuran kelembaban yang menunjukkan ketiga lokasi memiliki kelembaban yang sedang.

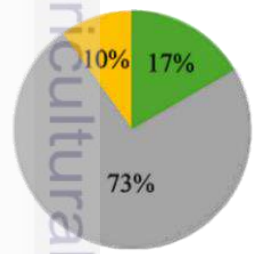

(a)

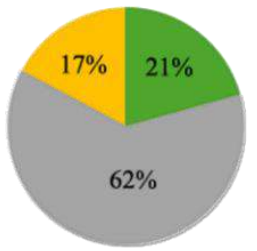

(b)

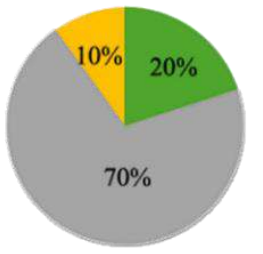

(c)

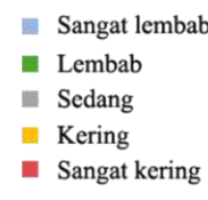

Gambar 19 Persentase persepsi responden tentang kelembaban udara di (a) Alunalun, (b) Taman Kota, dan (c) Kompleks Olahraga Wiradadaha 


\section{Fungsi penahan angin}

Angin menjadi faktor pelengkap dalam membentuk ameliorasi iklim mikro di suatu lingkungan. Menurut Fathy (1986) dalam Saputro (2010), angin menyebabkan tingkat kelembaban udara menurun. Angin yang melalui lingkungan bersuhu tinggi juga dapat memberi kenyamanan dengan penguapan pendinginan (Grey dan Daneke 1978). Angin juga dapat menimbulkan kerusakan sehingga tanaman sangat penting perannya dalam mengatur alur dan laju angin. Berikut adalah kriteria tanaman penahan angin:

K1 = Tanaman tinggi (Carpenter et al. 1975)

K2 = Daunnya tidak mudah gugur (Dahlan 1992)

K3 = Massa daun rapat (DPU Dirjen Bina Marga 1996)

K4 = Berdaun tebal (DPU Dirjen Bina Marga 1996)

Hasil penilaian tanaman terhadap fungsi penahan angin di ketiga lokasi penelitian dipaparkan ke dalam masing-masing Tabel 25, 26, dan 27.

Tabel 25 Penilaian aspek fungsi penahan angin di Alun-alun

\begin{tabular}{|c|c|c|c|c|c|c|c|}
\hline \multirow{2}{*}{ Nama ilmiah } & \multirow{2}{*}{ Nama lokal } & \multicolumn{4}{|c|}{$\begin{array}{c}\text { Kriteria fungsi penahan } \\
\text { angin }\end{array}$} & \multirow{2}{*}{$\begin{array}{l}\text { Skor } \\
(\%)\end{array}$} & \multirow{2}{*}{ Kategori } \\
\hline & & K1 & $\mathrm{K} 2$ & K3 & K4 & & \\
\hline $\begin{array}{l}\text { Araucaria } \\
\text { heterophylla }\end{array}$ & Cemara norfolk & 2 & 3 & 1 & 4 & 63 & Baik \\
\hline Bauhinia purpurea & Bunga kupu-kupu & 3 & 2 & 2 & 2 & 56 & Sedang \\
\hline Bismarckia nobilis & Bismark palm & 2 & 4 & 3 & 3 & 75 & Baik \\
\hline Coryota mitis & Palem ekor ikan & 2 & 4 & 1 & 3 & 63 & Baik \\
\hline Cyrtostachys renda & Palem merah & 2 & 4 & 1 & 3 & 63 & Baik \\
\hline Erythrina crista-galli & Dadap merah & 2 & 1 & 2 & 3 & 50 & Sedang \\
\hline Felicium decipiens & Krei payung & 4 & 2 & 4 & 3 & 81 & $\begin{array}{l}\text { Sangat } \\
\text { baik }\end{array}$ \\
\hline Ficus elastica & Beringin karet & 3 & 2 & 2 & 3 & 63 & Baik \\
\hline Ficus lyrata & Biola cantik & 3 & 2 & 4 & 2 & 69 & Baik \\
\hline $\begin{array}{l}\text { Leucaena } \\
\text { leucocephala }\end{array}$ & Lamtoro & 4 & 1 & 3 & 3 & 69 & Baik \\
\hline Mangifera indica & Mangga & 3 & 2 & 3 & 2 & 63 & Baik \\
\hline Plumeria rubra & Kamboja & 2 & 2 & 1 & 1 & 38 & Buruk \\
\hline Polyalthia longifolia & Glodogan tiang & 4 & 2 & 4 & 2 & 75 & Baik \\
\hline Pterocarpus indicus & Angsana & 4 & 1 & 2 & 2 & 56 & Sedang \\
\hline Samanea saman & Trembesi & 4 & 1 & 4 & 2 & 69 & Baik \\
\hline $\begin{array}{l}\text { Syzygium } \\
\text { campanulatum }\end{array}$ & Pucuk merah & 1 & 2 & 4 & 2 & 56 & Sedang \\
\hline Tabebuia chrysant & Tabebuia & 2 & 2 & 2 & 3 & 56 & Sedang \\
\hline Wodyetia bifurcata & Palem ekor tupai & 3 & 4 & 1 & 3 & 69 & Baik \\
\hline
\end{tabular}

Terdapat satu jenis pohon yang dinilai sangat baik sebagai penahan angin, yaitu krei payung (Felicium decipiens) yang berfungsi sebagi peneduh dan tersebar di sepanjang jalur jogging. Tanaman yang dikategorikan baik terdiri dari 11 jenis pohon dan merupakan 38\% dari total individu. 
(16)

$(1) 00.96$

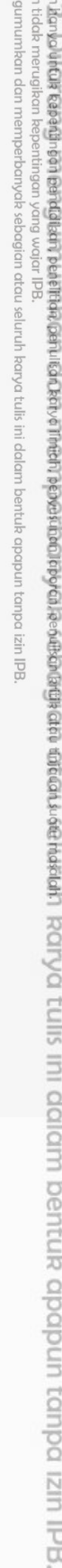

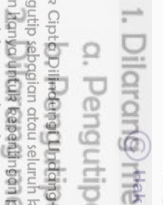

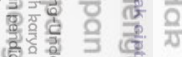

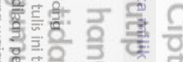

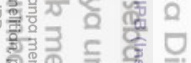

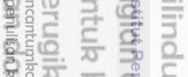

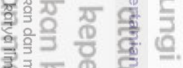

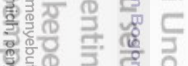

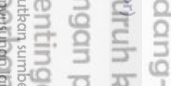

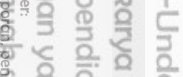

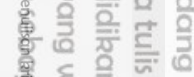

해을

핵을

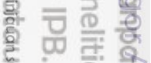

옥

할

高弯

을 월

용

产.

울 일

(

站

흘

응 훙
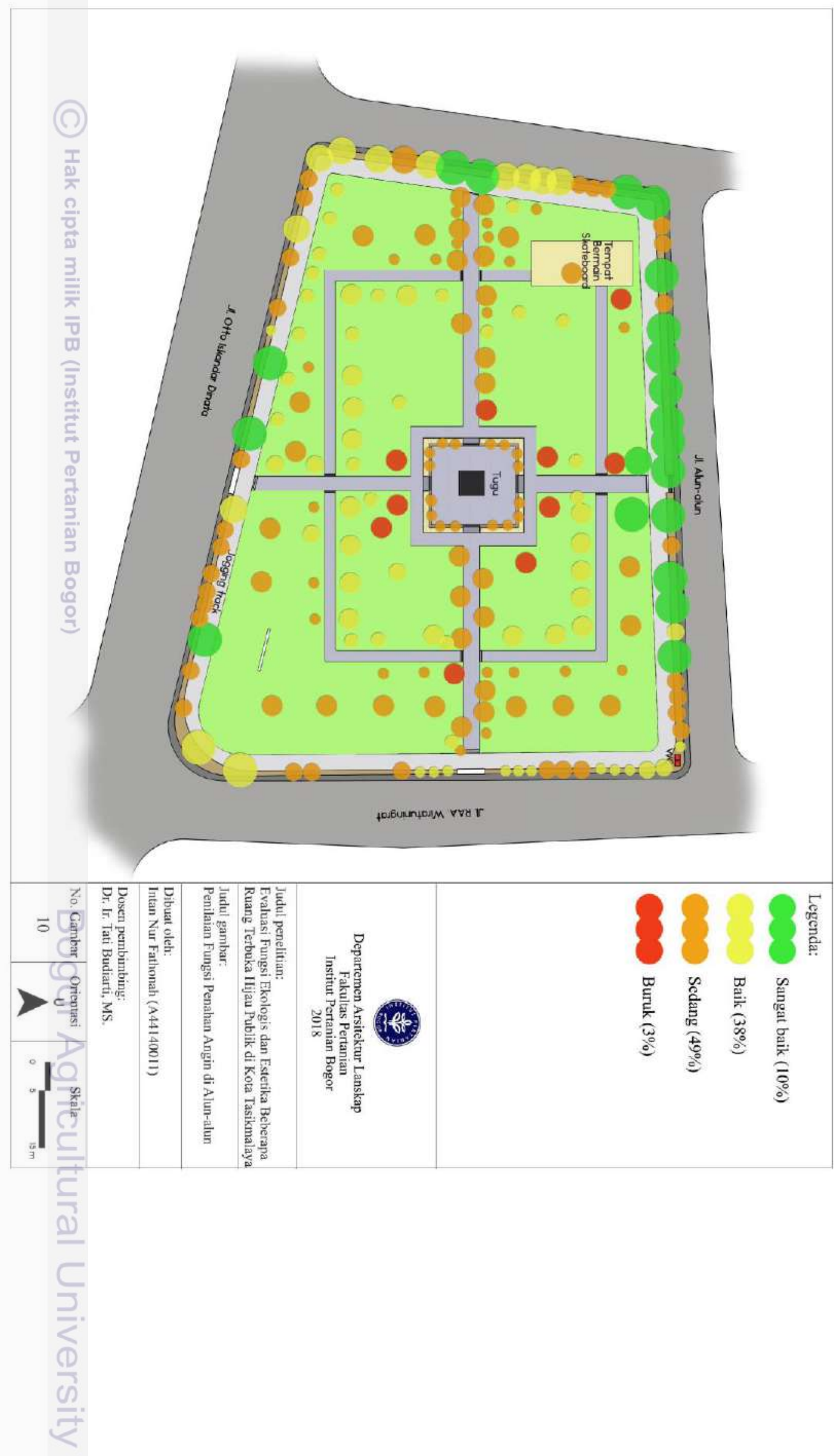
Sebagian besar tanaman yang dikategorikan baik berfungsi sebagai pengarah seperti glodogan tiang (Polyalthia longifolia) dan beberapa jenis palem. Sebagian lainnya merupakan tanaman peneduh seperti beringin karet (Ficus elastica), manga (Mangifera indica), dan trembesi (Samanea saman). Tanaman berkategori sedang terdiri dari 5 jenis pohon namun jumlahnya mendominasi sebanyak $49 \%$ dari jumlah total individu.

Persebaran tanaman berkategori sangat baik berada di sepanjang jalur jogging. Tanaman berkategori baik lebih banyak tersebar di area berumput di sekeliling tugu (Gambar 20). Persebaran dan penilaian tanaman sangat baik dan baik menunjukkan area yang memiliki kecepatan angin pelan. Tanaman yang dikategorikan baik dalam penahan angin sebaiknya diletakan di perbatasan tapak di mana aliran angin masuk. Terutama di batas tapak Timur dan Selatan yang masih didominasi oleh tanaman berkategori sedang.

Sebagian besar pengunjung yaitu sebanyak $63 \%$ menilai kecepatan angin di Âlun-alun sedang dan sebanyak 34\% dari responden menilai kecepatan angin di Allun-alun pelan. Berdasarkan persepsi responden, area Alun-alun yang paling banyak dinilai memiliki kecepatan pelan yaitu tempat bermain sketboard. Persepsi responden tidak sama persis dengan hasil penilaian tanaman dapat terjadi karena tidak adanya perbedaan kecepatan angin yang signifikan di setiap area Alun-alun. Berdasarkan hasil wawancara, terlihat pula sebagian besar responden berpersepsi bahwa kecepatan angin akan lebih pelan di area yang memiliki struktur perkerasan yang tertutup seperti area sketboard.

Taman Kota memiliki satu tanaman dengan penilaian yang sangat baik sebagai penahan angin yaitu krei payung (Felicium decipiens). Krei payung tersebar secara linear di sebelah Utara Taman Kota (Gambar 21). Tanaman berkategori baik mendominasi dengan persentase $51 \%$ dari jumlah individu total. Tanaman yang dikategorikan baik antara lain palem merah (Cyrtistachys renda) dan kimeng (Ficus microcarpa) yang berfungsi sebagai pemberi estetika, lamtoro (Leucaena leucocephala) yang berfungsi sebagai peneduh, serta glodogan tiang (Polyalthia longifolia) sebagai pengarah. Tanaman berkategori baik ini tersebar cukup merata di berbagai area Taman Kota.

Tabel 26 Penilaian aspek fungsi penahan angin di Taman Kota

\begin{tabular}{|c|c|c|c|c|c|c|c|}
\hline \multirow{2}{*}{ Nama ilmiah } & \multirow{2}{*}{ Nama lokal } & \multicolumn{4}{|c|}{$\begin{array}{l}\text { Kriteria fungsi penahan } \\
\text { angin }\end{array}$} & \multirow{2}{*}{$\begin{array}{l}\text { Skor } \\
(\%)\end{array}$} & \multirow{2}{*}{ Kategori } \\
\hline & & K1 & $\mathrm{K} 2$ & $\mathrm{~K} 3$ & $\mathrm{~K} 4$ & & \\
\hline Cyrtostachys renda & Palem merah & 2 & 4 & 1 & 3 & 63 & Baik \\
\hline $\begin{array}{l}\text { Erythrina crista- } \\
\text { galli }\end{array}$ & Dadap merah & 2 & 1 & 2 & 3 & 50 & Sedang \\
\hline Felicium decipiens & Krei payung & 4 & 2 & 4 & 3 & 81 & $\begin{array}{l}\text { Sangat } \\
\text { baik }\end{array}$ \\
\hline Ficus microcarpa & Kimeng & 2 & 2 & 3 & 3 & 63 & Baik \\
\hline $\begin{array}{l}\text { Leucaena } \\
\text { leucocephala }\end{array}$ & Lamtoro & 4 & 1 & 3 & 3 & 69 & Baik \\
\hline $\begin{array}{l}\text { Polyalthia } \\
\text { longifolia }\end{array}$ & Glodogan tiang & 4 & 2 & 4 & 2 & 75 & Baik \\
\hline Tabebuia chrysant & Tabebuia & 2 & 2 & 2 & 3 & 56 & Sedang \\
\hline Terminalia mantaly & Ketapang kencana & 3 & 1 & 2 & 1 & 44 & Sedang \\
\hline
\end{tabular}


6

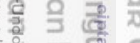

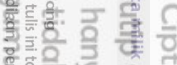

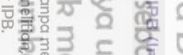

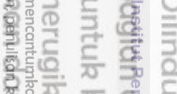

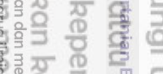

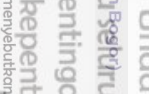

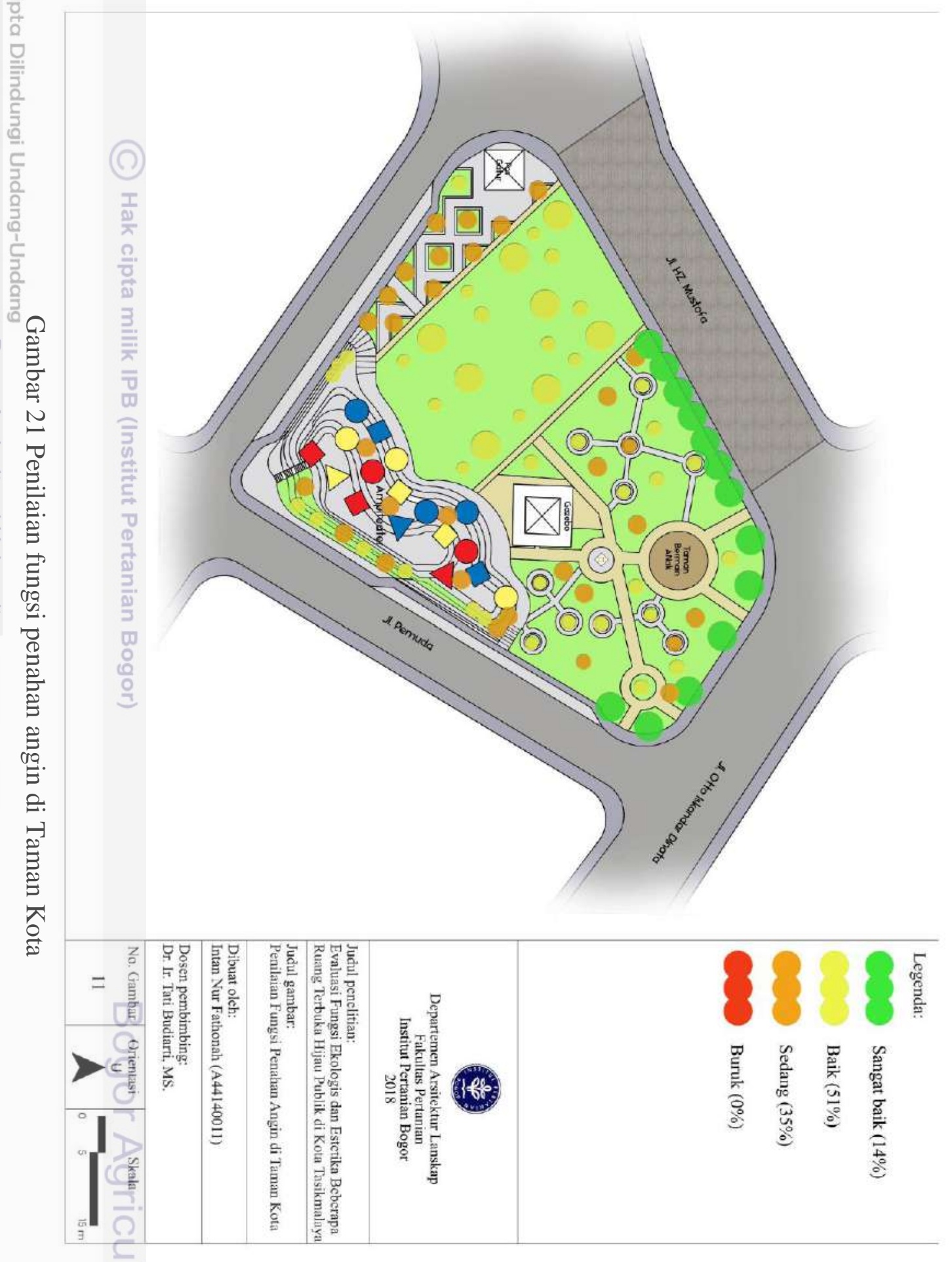

प्र 
Tanaman yang dikategorikan sedang tersebar sebanyak 35\% dari total individu. Tanaman yang dikategorikan sedang terdiri dari dadap merah (Erythrina crista-galli) dan ketapang kencana (Terminalia mantaly). Tanaman berkategori sedang banyak tersebar hampir di area Selatan dan ampiteater Taman Kota.

Sebanyak $77 \%$ dari responden di Taman Kota menilai bahwa kecepatan angin di Taman Kota sedang. Responden yang menilai kecepatan angin di Taman Kota pelan sebanyak 20\% sedangkan 3\% sisanya menilai kecepatan angin di Taman Kota kencang. Ampiteater merupakan lokasi yang dinilai oleh 36\% responden memiliki kecepatan angin yang rendah.

Ampiteater yang terbuat dari beton dan dibangun meninggi ini dirasa mampu menghalau angin yang datang. Hal tersebut dapat terjadi namun berdasarkan persebaran dan penilaian tanaman, area parklet merupakan area yang dinilai memiliki kecepatan angin pelan. Area parklet tidak didominasi oleh tanaman berkategori baik namun keberadaan jumlah tanaman di sana lebih banyak.

Terdapat dua jenis tanaman yang dikategorikan sangat baik berdasarkan füngsinya sebagai penahan angin di Kompleks Olahraga Wiradadaha. Tanaman berkategori sangat baik ini terdiri dari krei payung (Felicium decipiens) dan cemara (Casuarina sp.). Tanaman yang dikategorikan baik mendominasi dengan $60 \%$ dari total individu dan terdiri dari 16 jenis tanaman. Beberapa tanaman yang dikategorikan baik tersebar hampir di seluruh area Kompleks Olahraga Wiradadaha.

Tabel 27 Penilaian aspek fungsi penahan angin di Kompleks Olahraga Wiradadaha

\begin{tabular}{|c|c|c|c|c|c|c|c|}
\hline \multirow{2}{*}{ Nama ilmiah } & \multirow{2}{*}{ Nama lokal } & \multicolumn{4}{|c|}{$\begin{array}{l}\text { Kriteria fungsi penahan } \\
\text { angin }\end{array}$} & \multirow{2}{*}{$\begin{array}{l}\text { Skor } \\
(\%)\end{array}$} & \multirow{2}{*}{ Kategori } \\
\hline & & $\mathrm{K} 1$ & $\mathrm{~K} 2$ & K3 & $\mathrm{K} 4$ & & \\
\hline Acacia auriculiformis & Akasia & 4 & 1 & 2 & 2 & 56 & Sedang \\
\hline Acacia longifolia & Akasia & 4 & 1 & 2 & 2 & 56 & Sedang \\
\hline Alstonia scholaris & Pulai & 3 & 2 & 4 & 3 & 75 & Baik \\
\hline Bauhinia purpurea & Bunga kupu-kupu & 3 & 2 & 2 & 2 & 56 & Sedang \\
\hline Butia capitata & Jelly palm & 1 & 4 & 2 & 3 & 63 & Baik \\
\hline Casuarina sp. & Cemara & 4 & 3 & 4 & 4 & 94 & Sangat baik \\
\hline Cerbera odollam & Bintaro & 3 & 1 & 4 & 3 & 69 & Baik \\
\hline Erythrina crista-galli & Dadap merah & 2 & 1 & 2 & 3 & 50 & Sedang \\
\hline Felicium decipiens & Krei payung & 4 & 2 & 4 & 3 & 81 & Sangat baik \\
\hline Ficus benjamina & Beringin & 3 & 1 & 3 & 3 & 63 & Baik \\
\hline Ficus elastica & Beringin karet & 3 & 2 & 2 & 3 & 63 & Baik \\
\hline Ficus lyrata & Biola cantik & 3 & 2 & 4 & 2 & 69 & Baik \\
\hline $\begin{array}{l}\text { Leucaena } \\
\text { leucocephala }\end{array}$ & Lamtoro & 4 & 1 & 3 & 3 & 69 & Baik \\
\hline Mangifera indica & Mangga & 3 & 2 & 3 & 2 & 63 & Baik \\
\hline Manilkara kaukii & Sawo kecik & 3 & 1 & 2 & 3 & 56 & Sedang \\
\hline Maniltoa grandiflora & $\begin{array}{l}\text { Pohon sapu } \\
\text { tangan }\end{array}$ & 4 & 1 & 3 & 2 & 63 & Baik \\
\hline Mimusoph elengi L. & Tanjung & 2 & 2 & 2 & 2 & 50 & Sedang \\
\hline
\end{tabular}


Tabel 28 Penilaian aspek fungsi penahan angin di Kompleks Olahraga Wiradadaha (lanjutan)

\begin{tabular}{|c|c|c|c|c|c|c|c|}
\hline \multirow[t]{2}{*}{ Nama ilmiah } & \multirow[t]{2}{*}{ Nama lokal } & \multicolumn{4}{|c|}{$\begin{array}{c}\text { Kriteria fungsi penahan } \\
\text { angin }\end{array}$} & \multirow{2}{*}{$\begin{array}{l}\text { Skor } \\
(\%)\end{array}$} & \multirow[t]{2}{*}{ Kategori } \\
\hline & & K1 & $\mathrm{K} 2$ & K3 & $\mathrm{K} 4$ & & \\
\hline Morinda citrifolia $L$. & Mengkudu & 2 & 2 & 3 & 2 & 56 & Sedang \\
\hline Muntingi calabura & Kersen & 2 & 1 & 4 & 3 & 63 & Baik \\
\hline Ochroma pyramidale & Balsa & 4 & 2 & 2 & 1 & 56 & Sedang \\
\hline Plumeria rubra & Kamboja & 2 & 2 & 1 & 1 & 38 & Buruk \\
\hline Polyalthia fragrans & Glodogan bulat & 3 & 2 & 2 & 2 & 56 & Sedang \\
\hline Polyalthia longifolia & Glodogan tiang & 4 & 2 & 4 & 2 & 75 & Baik \\
\hline Pometia pinnata & Matoa & 3 & 2 & 3 & 3 & 69 & Baik \\
\hline Psidium guajava & Jambu & 3 & 1 & 2 & 3 & 56 & Sedang \\
\hline Pterocapus indicus & Angsana & 4 & 1 & 3 & 2 & 63 & Baik \\
\hline Roystone regia & Palem raja & 4 & 1 & 1 & 2 & 50 & Sedang \\
\hline Samanea saman & Trembesi & 4 & 1 & 4 & 2 & 69 & Baik \\
\hline Schleichera oleosa & Kesambi & 3 & 1 & 2 & 2 & 50 & Sedang \\
\hline Senna siamea & Johar & 4 & 1 & 3 & 2 & 63 & Baik \\
\hline Switenia mahogani & Mahoni & 3 & 2 & 3 & 3 & 69 & Baik \\
\hline $\begin{array}{l}\text { Syzygium } \\
\text { campanulatum }\end{array}$ & Pucuk merah & 1 & 2 & 4 & 2 & 56 & Sedang \\
\hline Tabebuia chrysant & Tabebuia & 2 & 2 & 2 & 3 & 56 & Sedang \\
\hline Terminalia catappa & Ketapang & 4 & 1 & 2 & 3 & 63 & Baik \\
\hline Terminalia mantaly & Ketapang kencana & 3 & 1 & 2 & 2 & 50 & Sedang \\
\hline Wodyetia bifurcata & Palem ekor tupai & 3 & 4 & 1 & 3 & 69 & Baik \\
\hline Schleichera oleosa & Kesambi & 3 & 1 & 2 & 2 & 50 & Sedang \\
\hline
\end{tabular}

Persentase tanaman berkategori sedang terhadap total individu yaitu $34 \%$ yang terdiri dari 15 jenis tanaman. Tanaman yang dikategorikan sedang tersebar tidak merata di berbagai area. Satu tanaman berkategori sedang yaitu dadap merah (Erythrina crista-galli) ditanam berkelompok di Taman Dadaha. Tanaman yang dikategorikan buruk terdiri dari satu jenis tanaman yaitu kamboja (Plumeria rubra). Kamboja memilik kerapatan daun yang rendah dan mudah gugur sehingga tidak baik sebagai penahan angin

Sebagian besar responden yaitu sebanyak $70 \%$ dari total responden menilai kecepatan angin di Kompleks Olahraga Wiradadaha sedang dan sebanyak 30\% lainnya menilai kecepatan angin di Kompleks Olahraga Wiradadaha pelan. Sebanyak $36 \%$ responden memilih lapangan olahraga sebagai area yang memiliki kecepatan angin pelan. Hal itu dapat terjadi karena lapangan olahraga voli dan basket dikelilingi oleh tanaman berkategori sangat baik hingga baik yang dapat menurunkan kecepatan angin. Lapangan sepak bola yang berada di dalam stadion juga dapat terlindungi dari kecepatan angin yang kencang oleh struktur bangunan stadion. 
16

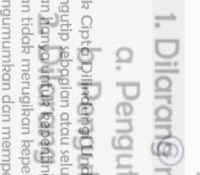

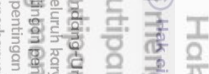

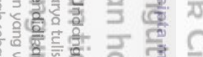

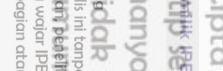

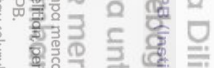

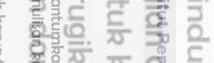

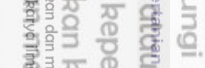

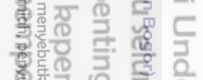

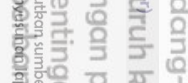

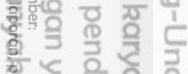

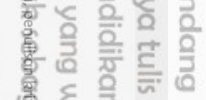

․․ㄹ.

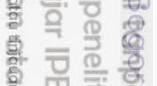

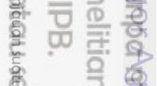

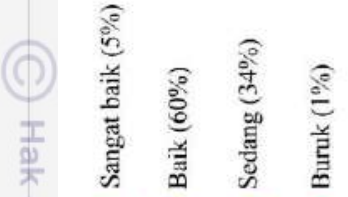

18888

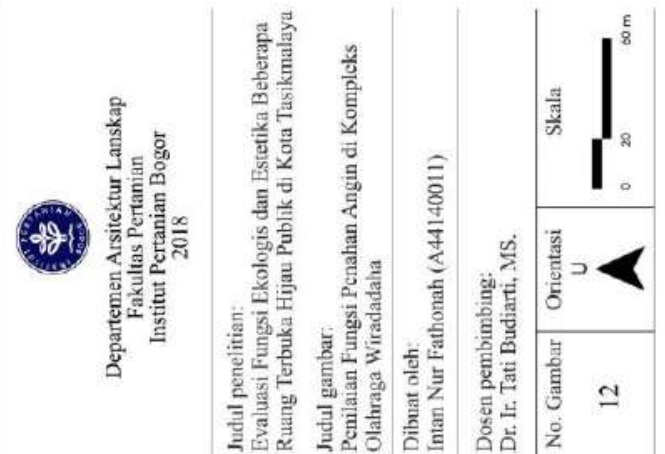

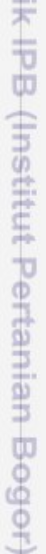

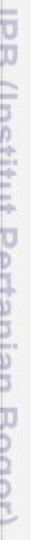
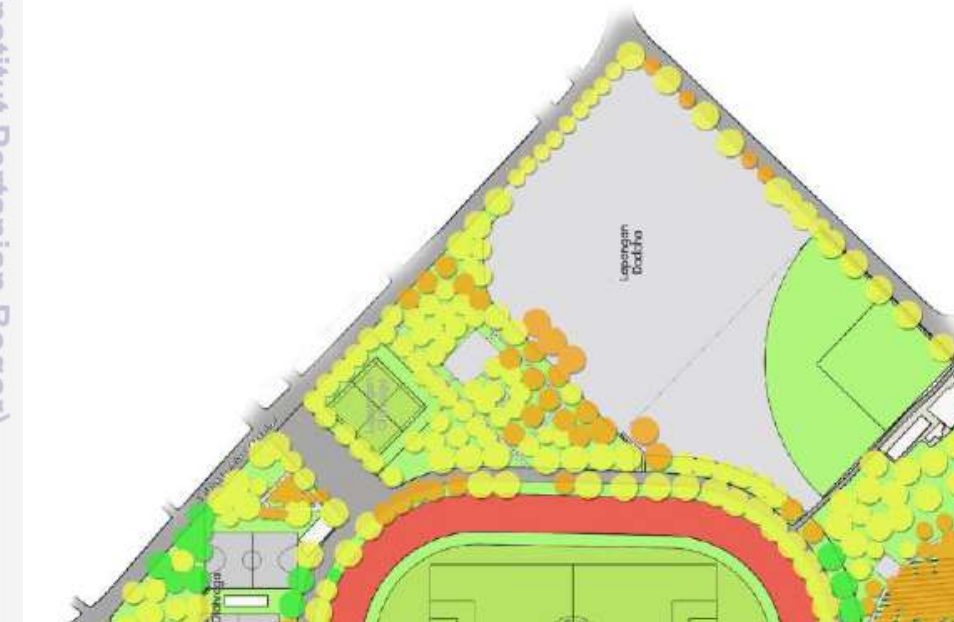
Berdasarkan hasil persebaran dan penilaian tanaman, jalur jogging, area kebugaran, dan area hutan kota dinilai menjadi area yang memiliki kecepatan angin paling pelan. Perbedaan antara persepsi responden dengan hasil penilaian dapat terjadi kerena perbedaan persepsi dan pengetahuan mengenai fungsi tanaman. Sebagian besar responden berpersepsi kecepatan angin di lapangan terbuka lebih pelan dibandingkan di bawah tanaman. Jarangnya responden merasakan perbedaan kondisi kecepatan angin yang ekstrim juga dapat melatarbelakangi persepsi responden dalam menilai kecepatan angin di Kompleks Olahraga Wiradadaha.

Keseluruhan hasil penilaian tanaman terhadap fungsi penahan angin menunjukkan bahwa Taman Kota mendapat skor tertinggi sebesar 280 namun masih dalam kategori sedang. Alun-alun mendapat nilai skor terendah sebesar 254 (Tabel 28). Hasil penilaian tanaman ini sejalan dengan persepsi responden terhadap kecepatan angin (Gambar 23). Responden rata-rata memilih sedang pada setiap kecepatan angin di masing-masing RTH. Kecepatan angin di dalam area mikro ratarata tidak terlalu berbeda di setiap areanya sehingga tidak begitu dirasakan perbedaan kecepatannya oleh pengunjung dan tidak banyak mempengaruhi kondisi iklim mikro secara langsung.

Tabel 28 Persentase penilaian tanaman fungsi penahan angin

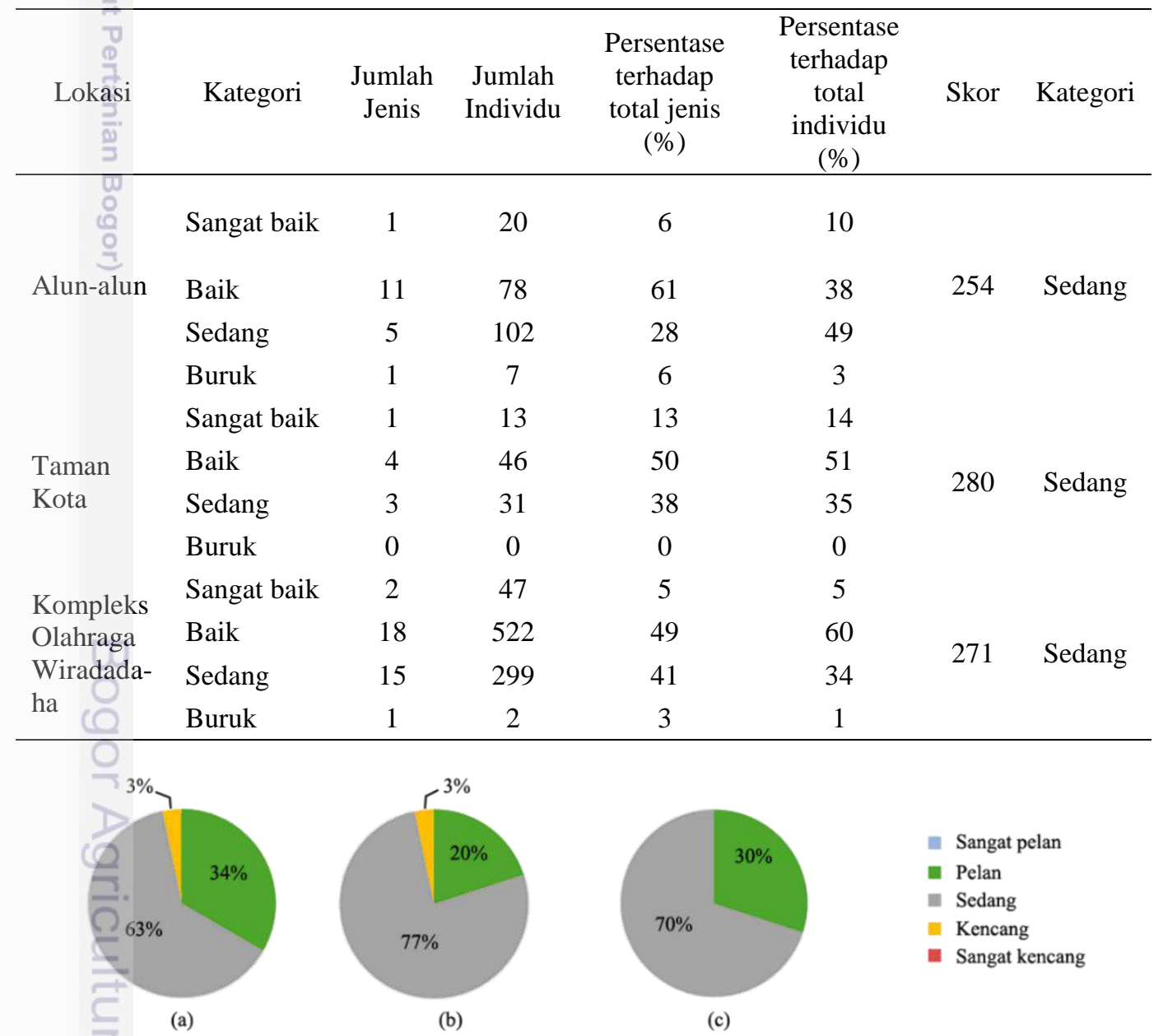

Gambar 23 Persentase persepsi responden tentang kecepatan angin di (a) Alun-alun, (b) Taman Kota, dan (c) Kompleks Olahraga Wiradadaha 


\section{Fungsi peredam kebisingan}

Baku mutu tingkat kebisingan pada suatu kawasan menjadi salah satu parameter kenyamanan di kawasan tersebut. Terlebih lagi bagi RTH perkotaan yang terletak di pusat kota. Menurut KepMNLH No. KEP-48/MENLH/11/1996, baku mutu tingkat kebisingan suatu RTH yaitu $50 \mathrm{~dB}$ namun kegiatan yang dilakukan di ketiga RTH adalah rekreasi. Berdasarkan dominannya kegiatan rekreasi dalam RTH maka baku mutu yang dijadikan pembanding yaitu baku mutu tingkat kebisingan kawasan rekreasi sebesar $70 \mathrm{~dB}$. Salah satu fungsi tanaman yaitu mengurangi tingkat kebisingan di sekitarnya. Berikut adalah kriteria tanaman dengan fungsi peredam kebisingan:

K1 = Tajuk rapat dan massa daun rapat (DPU Dirjen Bina Marga 1996)

K2 = Berdaun tebal (Grey dan Deneke 1978)

K3 = Struktur cabang dan batang besar (Grey dan Deneke 1978)

K4 = Berdaun jarum (Grey dan Deneke 1978)

Hasil penilaian aspek fungsi peredam kebisingan di setiap lokasi penelitian dipaparkan dalam masing-masing Tabel 29, 31, dan 33.

Tanaman yang dikategorikan baik terdiri dari 8 jenis tanaman dengan persentase $32 \%$ dari total individu. Tanaman berkategori sedang pun terdiri dari 8 jenis tanaman dengan persentase $64 \%$ dari total individu. Tanaman berkategori baik banyak tersebar di sepanjang jalur jogging dan perkerasan dengan pola linear sedangkan tanaman berkategori sedang tersebar acak di area berumput.

Penempatan tanaman berkategori baik di sepanjang jalur jogging sekaligus sebagai pembatas tapak dari luar sangat baik karena dapat meredam kebisingan yang bersumber dari luar tapak. Peredaman kebisingan akan semakin optimal bila dapat dilakukan penambahan tanaman yang dapat mengisi kekosongan di sepanjang jalur jogging tersebut. Tanaman dapat meredam kebisingan dengan efektif ditentukan oleh ketebalan dan kerapatan tanaman (Slamet 2003).

Tabel 29 Penilaian aspek fungsi peredam kebisingan di Alun-alun

\begin{tabular}{|c|c|c|c|c|c|c|c|}
\hline \multirow{2}{*}{ Nama ilmiah } & \multirow{2}{*}{ Nama lokal } & \multicolumn{4}{|c|}{$\begin{array}{c}\text { Kriteria fungsi peredam } \\
\text { kebisingan }\end{array}$} & \multirow{2}{*}{$\begin{array}{l}\text { Skor } \\
(\%)\end{array}$} & \multirow{2}{*}{ Kategori } \\
\hline & & $\mathrm{K} 1$ & K2 & K3 & K4 & & \\
\hline $\begin{array}{l}\text { Araucaria } \\
\text { heterophylla }\end{array}$ & $\begin{array}{l}\text { Cemara } \\
\text { norfolk }\end{array}$ & 1 & 4 & 2 & 4 & 69 & Baik \\
\hline Bauhinia purpurea & $\begin{array}{l}\text { Bunga kupu- } \\
\text { kupu }\end{array}$ & 2 & 2 & 3 & 3 & 63 & Baik \\
\hline Bismarckia nobilis & Bismark palm & 3 & 3 & 1 & 2 & 56 & Sedang \\
\hline Coryota mitis & $\begin{array}{l}\text { Palem ekor } \\
\text { ikan }\end{array}$ & 1 & 3 & 1 & 2 & 44 & Sedang \\
\hline Cyrtostachys renda & Palem merah & 1 & 3 & 1 & 2 & 44 & Sedang \\
\hline $\begin{array}{l}\text { Erythrina crista- } \\
\text { galli }\end{array}$ & Dadap merah & 2 & 3 & 3 & 1 & 56 & Sedang \\
\hline Felicium decipiens & Krei payung & 4 & 3 & 4 & 1 & 75 & Baik \\
\hline Ficus elastica & Beringin karet & 2 & 3 & 3 & 1 & 56 & Sedang \\
\hline Ficus lyrata & Biola cantik & 4 & 2 & 4 & 1 & 69 & Baik \\
\hline $\begin{array}{l}\text { Leucaena } \\
\text { leucocephala }\end{array}$ & Lamtoro & 3 & 3 & 4 & 3 & 81 & $\begin{array}{l}\text { Sangat } \\
\text { baik }\end{array}$ \\
\hline Mangifera indica & Mangga & 3 & 2 & 4 & 1 & 63 & Baik \\
\hline
\end{tabular}


Tabel 29 Penilaian aspek fungsi peredam kebisingan di Alun-alun (lanjutan)

\begin{tabular}{|c|c|c|c|c|c|c|c|}
\hline \multirow[t]{2}{*}{ Nama ilmiah } & \multirow[t]{2}{*}{ Nama lokal } & \multicolumn{4}{|c|}{$\begin{array}{c}\text { Kriteria fungsi peredam } \\
\text { kebisingan }\end{array}$} & \multirow{2}{*}{$\begin{array}{l}\text { Skor } \\
(\%)\end{array}$} & \multirow[t]{2}{*}{ Kategori } \\
\hline & & K1 & $\mathrm{K} 2$ & K3 & K4 & & \\
\hline Plumeria rubra & Kamboja & 1 & 1 & 3 & 1 & 38 & Buruk \\
\hline Polyalthia longifolia & $\begin{array}{l}\text { Glodogan } \\
\text { tiang }\end{array}$ & 4 & 2 & 2 & 1 & 56 & Sedang \\
\hline Pterocarpus indicus & Angsana & 2 & 2 & 4 & 3 & 69 & Baik \\
\hline Samanea saman & Trembesi & 4 & 2 & 4 & 1 & 69 & Baik \\
\hline $\begin{array}{l}\text { Syzygium } \\
\text { campanulatum }\end{array}$ & Pucuk merah & 4 & 2 & 2 & 1 & 56 & Sedang \\
\hline Tabebuia chrysant & Tabebuia & 2 & 3 & 3 & 3 & 69 & Baik \\
\hline Wodyetia bifurcata & $\begin{array}{l}\text { Palem ekor } \\
\text { tupai }\end{array}$ & 1 & 3 & 1 & 2 & 44 & Sedang \\
\hline
\end{tabular}

Hasil pengukuran kebisingan di Alun-alun tidak terlepas dari dinamika kesibukan lalu lintas di jalan raya yang mengelilinginya. Kebisingan di pagi hari cenderung tinggi karena merupakan waktu berangkat kerja dan sekolah. Alun-alun berada di antara tiga sekolah menengah pertama dan sebelah Tenggara Alun-alun merupakan salah satu persimpangan jalan utama kota. Kebisingan di pagi hari juga dipengaruhi oleh kebisingan instrumen lagu senam yang rutin dilaksanakan di Alun-alun. Kebisingan pada siang hari lebih banyak dipengaruhi oleh kebisingan lalu lintas dan kebisingan menurun memasuki sore hari.

Perbedaan tingkat kebisingan juga terlihat pada masing-masing titik. Titik P3 cenderung memiliki titik kebisingan yang rendah dibandingkan kedua titik lain (Tabel 30$)$. Titik P3 berada di sebelah Utara Alun-alun yang berbatasan dengan jalan kecil menuju Pendopo Kabupaten Tasikmalaya sehingga tidak banyak aktivitas yang terjadi di sana. Titik P1 dan P2 berada di sebelah Timur dan Selatan Alun-alun yang berbatasan dengan jalan utama kota (Gambar 24).

Perbedaan kebisingan dipengaruhi oleh kondisi dan jenis tanaman yang menjadi batas tapak dan kondisi di luar tapak. Titik P1 berada di sebelah Timur Alun-alun. Tanaman yang membatasinya yaitu glodogan tiang (Polyalthia longifolia). Titik P2 berada di sebelah Selatan Alun-alun sedangkan titik P3 berada di sebelah Utara Alun-alun. Titik P2 dan P3 dibatasi oleh krei payung (Felicium decipiens).

Tabel 30 Hasil pengukuran kebisingan di Alun-alun

\begin{tabular}{|c|c|c|c|c|c|c|}
\hline \multirow{2}{*}{ Waktu } & \multicolumn{3}{|c|}{ Dalam RTH } & \multirow{2}{*}{$\begin{array}{c}\text { Rata-rata } \\
\text { dalam } \\
\text { RTH } \\
(\mathrm{dB})\end{array}$} & \multirow{2}{*}{$\begin{array}{l}\text { Rata-rata } \\
\text { luar RTH } \\
\quad(\mathrm{dB})\end{array}$} & \multirow{2}{*}{ Selisih $(\mathrm{dB})$} \\
\hline & $\mathrm{P} 1 *(\mathrm{~dB})$ & $\mathrm{P} 2 *(\mathrm{~dB})$ & $\mathrm{P} 3 *(\mathrm{~dB})$ & & & \\
\hline Pagi & 66.3 & 66.9 & 63.9 & 65.7 & 70.1 & 4.4 \\
\hline Siang? & 68.0 & 67.1 & 60.3 & 65.2 & 68.4 & 3.2 \\
\hline Sore $=$ & 64.1 & 63.9 & 62.8 & 63.6 & 67.5 & 3.9 \\
\hline Rata-rata & 66.1 & 66.0 & 62.3 & 64.8 & 68.6 & 3.8 \\
\hline
\end{tabular}

* P1, P2, dan P3 merupakan rata-rata data dari waktu pengambilan data di 3 titik dalam $\mathrm{RTH}$ 
(16)

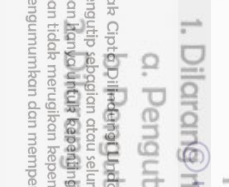

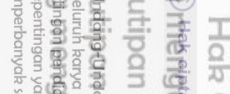

s.

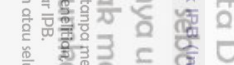

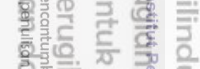

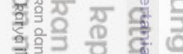

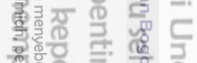

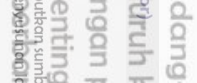

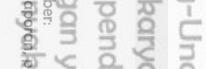

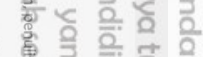

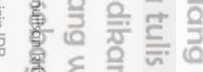

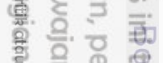

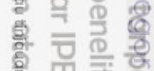

急

할 항

空

질

용

站.

ए

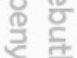

言

을 吾

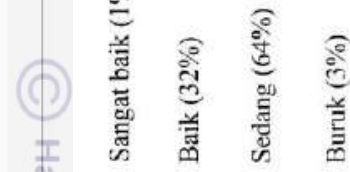

18888
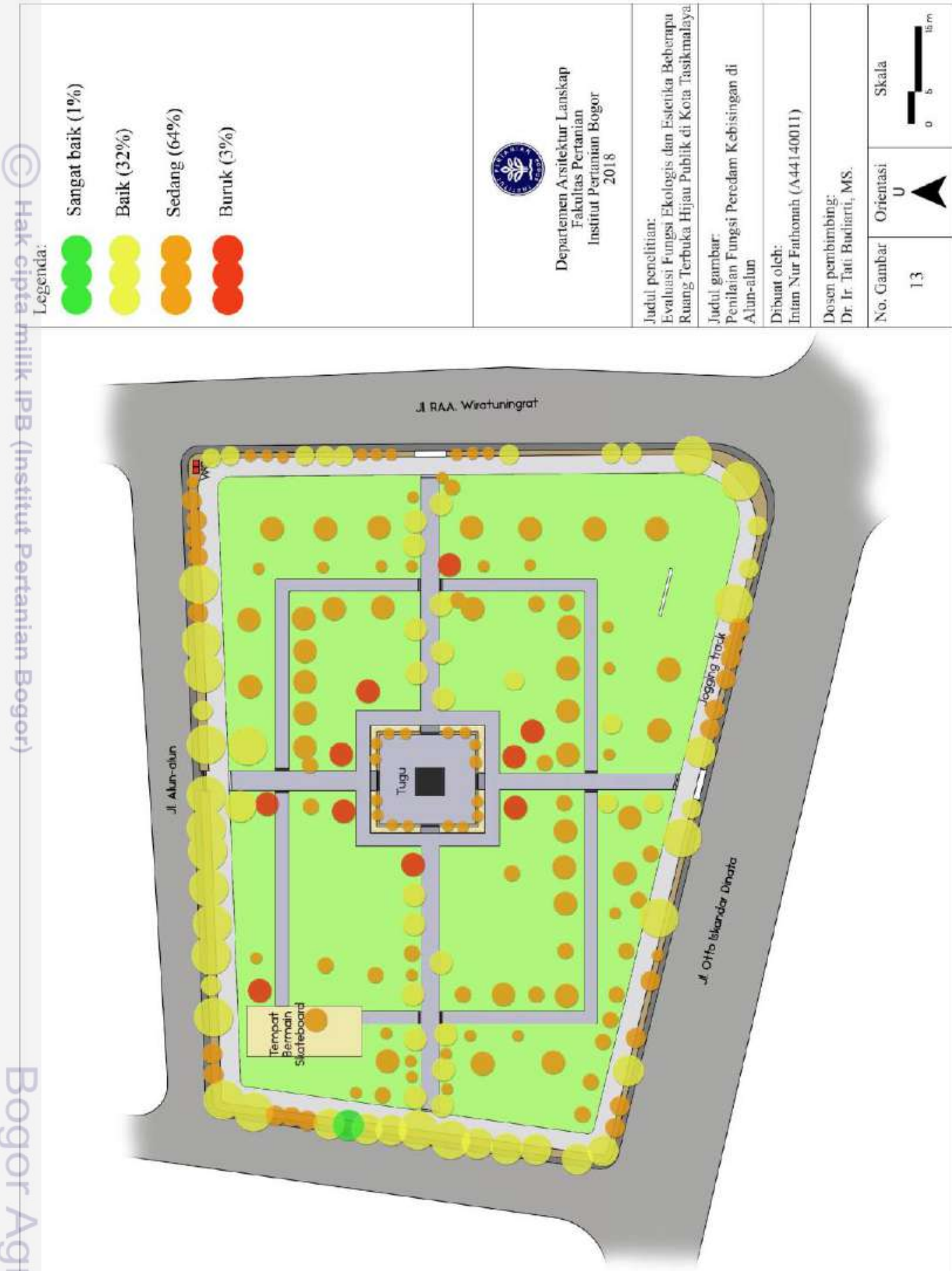

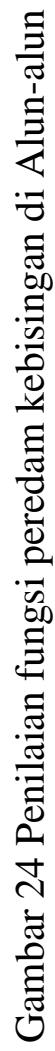


Bila dibandingkan berdasarkan tanamannya, krei payung (Felicium decipiens) memiliki skor lebih tinggi dibandingkan glodogan tiang (Polyalthia longifolia) sehingga keberadaan krei payung akan lebih berpengaruh dalam meredam kebisingan. Kondisi kerapatan tajuk antar tanaman di sebelah Timur dan Selatan lebih renggang dibandingkan kerapatan tajuk di sebelah Barat dan Utara tapak. Bila dirata-ratakan, titik P1 di sebelah Timur dalam tapak memiliki tingkat kebisingan tertinggi begitupun di luar tapaknya. Tingkat kebisingan terendah berada di titik P3 di dalam maupun luar tapak karena kualitas tanaman yang membatasinya dan kondisi luar tapak yang lebih rendah pula kebisingannya.

Kebisingan di Alun-alun masih cukup tinggi yaitu rata-rata sebesar $64.8 \mathrm{~dB}$ namun sudah memenuhi baku mutu kebisingan kawasan rekreasi sebesar $70 \mathrm{~dB}$. Jalur lingkar luar Alun-alun didominasi oleh pepohonan besar. Keberadaan pepohonan yang telah ada tersebut perlu dilengkapi oleh semak-semak yang mampu meredam kebisingan dari sumber kebisingan yang rendah.

Tanaman yang dikategorikan sedang di Taman Kota mendominasi dengan persentase $70 \%$ dari total individu. Tanaman berkategori baik hanya terdiri dari dua pohon yang memiliki persentase $18 \%$ dari total individu. Hal itu membuat pengaruh tanaman berkategori baik belum cukup kuat untuk meredam kebisingan.

Taman Kota memiliki pola berkelompok menyebar (Gambar 25). Pola penanaman di batas tapak pun tidak rapat sehingga kebisingan masih dapat masuk ke dalam tapak. Kurangmnya pengkombinasian tanaman yang memiliki variasi ketinggian juga membuat fungsi peredaman kebisingan oleh tanaman belum optimal. Kombinasi ketinggian dan kerapatan tanaman menjadi penting dalam fungsinya sebagai peredam kebisingan.

Tabel 31 Penilaian aspek fungsi peredam kebisingan di Taman Kota

\begin{tabular}{|c|c|c|c|c|c|c|c|}
\hline \multirow[t]{2}{*}{ Nama ilmiah } & \multirow[t]{2}{*}{ Nama lokal } & \multicolumn{4}{|c|}{$\begin{array}{c}\text { Kriteria fungsi peredam } \\
\text { kebisingan }\end{array}$} & \multirow{2}{*}{$\begin{array}{l}\text { Skor } \\
(\%)\end{array}$} & \multirow[t]{2}{*}{ Kategor } \\
\hline & & $\mathrm{K} 1$ & $\mathrm{~K} 2$ & $\mathrm{~K} 3$ & K4 & & \\
\hline $\begin{array}{l}\text { Cyrtostachys } \\
\text { renda }\end{array}$ & Palem merah & 1 & 3 & 1 & 2 & 44 & Sedang \\
\hline $\begin{array}{l}\text { Erythrina crista- } \\
\text { galli }\end{array}$ & Dadap merah & 2 & 3 & 3 & 1 & 56 & Sedang \\
\hline Felicium decipiens & Krei payung & 4 & 3 & 4 & 1 & 75 & Baik \\
\hline Ficus microcarpa & Kimeng & 3 & 3 & 2 & 1 & 56 & Sedang \\
\hline $\begin{array}{l}\text { Leucaena } \\
\text { leucocephala }\end{array}$ & Lamtoro & 3 & 3 & 4 & 3 & 81 & $\begin{array}{l}\text { Sangat } \\
\text { baik }\end{array}$ \\
\hline $\begin{array}{l}\text { Polyalthia } \\
\text { longifolia }\end{array}$ & Glodogan tiang & 4 & 2 & 2 & 1 & 56 & Sedang \\
\hline Tabebuia chrysant & Tabebuia & 2 & 3 & 3 & 3 & 69 & Baik \\
\hline $\begin{array}{l}\text { Terminalia } \\
\text { mantaly }\end{array}$ & $\begin{array}{l}\text { Ketapang } \\
\text { kencana }\end{array}$ & 2 & 1 & 3 & 1 & 44 & Sedang \\
\hline
\end{tabular}

Pengukuran kebisingan di Taman Kota dilakukan di sebelah Timur Laut dan Barat Daya Taman Kota karena hanya dari kedua arah itu sumber kebisingan berada. Taman Kota berada tepat di pusat keramaian kota karena di sekitarnya terdapat beberapa perkantoran dan pusat perbelanjaan. Kebisingan hampir terjadi di setiap waktu. 
(16)

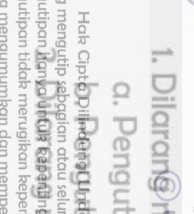

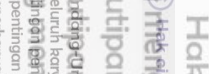

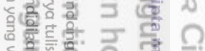

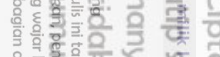

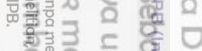

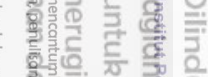

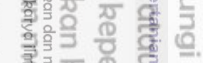

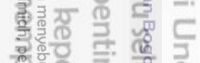

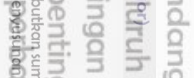

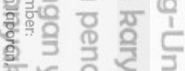
鹤高

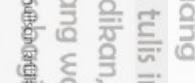

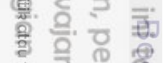

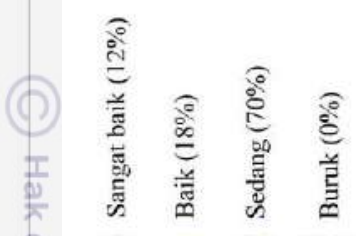

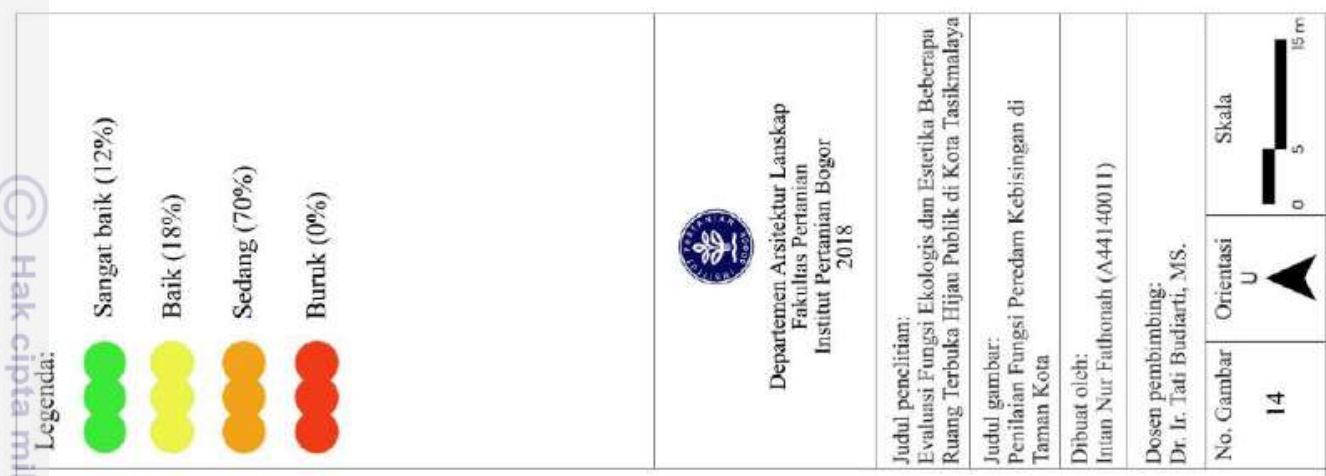

$$
\text { 高 }
$$

함

을

돈

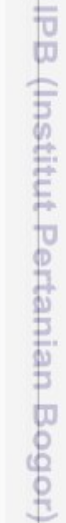

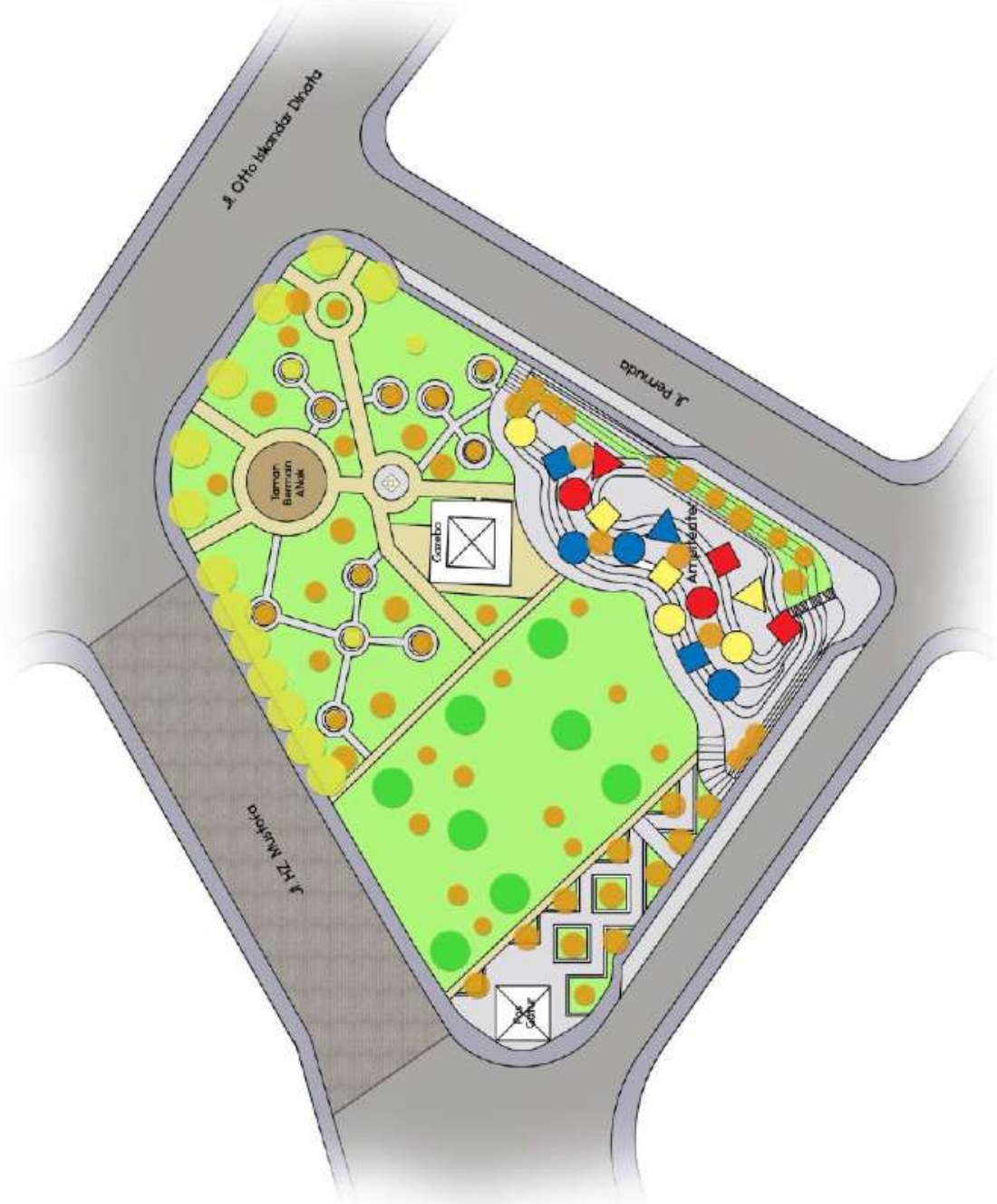

풍

สี

हี

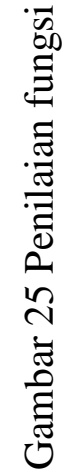


Kebisingan pada pagi hari terjadi karena kesibukan lalu lintas kendaraan. Kebisingan pada siang hari lebih dikarenakan suara murratal yang dilantunkan dari Masjid Agung yang berada di sebelah Barat Laut Taman Kota sesaat sebelum adzan dzuhur dikumandangkan. Meskipun bukan kebisingan yang mengganggu, namun suara yang berasal dari Masjid Agung mempengaruhi tingkat kebisingan Taman Kota. Kebisingan pada sore hari terjadi karena tingkat pengunjung meningkat, baik pengunjung Taman Kota maupun pengunjung pusat perbelanjaan, sehingga mengakibatkan tingkat kesibukan lalu lintas pun meningkat.

Kebisingan di kedua titik pengukuran tidak berbeda jauh. Selain karena luas tapak yang kecil, kondisi pola penanaman tanaman yang sama juga tidak terlalu membedakan pengaruhnya dalam meredam kebisingan. Pola penanaman tanaman cenderung berkelompok campuran dan menyebar dengan tajuk-tajuk yang tidak rapat menyebabkan peredaman kebisingan kurang efektif.

Tabel 32 Hasil pengukuran kebisingan di Taman Kota

\begin{tabular}{cccccc}
\hline \multirow{2}{*}{\begin{tabular}{c} 
Waktu \\
\cline { 2 - 3 }
\end{tabular}} & \multicolumn{2}{c}{ Dalam RTH } & $\begin{array}{c}\text { Rata-rata dalam } \\
\text { RTH }(\mathrm{dB})\end{array}$ & $\begin{array}{c}\text { Rata-rata luar } \\
\text { RTH }(\mathrm{dB})\end{array}$ & $\begin{array}{c}\text { Selisih } \\
(\mathrm{dB})\end{array}$ \\
\cline { 2 - 4 } Pagi & 68.9 & 64.8 & 66.9 & 70.5 & 3.6 \\
Siang & 68.9 & 71.5 & 70.2 & 74.9 & 4.7 \\
Sore & 66.9 & 68.0 & 67.4 & 71.8 & 4.3 \\
Rata-rata & 68.2 & 68.1 & 68.2 & 72.4 & 4.2 \\
\hline
\end{tabular}

* P1 dan P2 merupakan rata-rata data dari waktu pengambilan data di 2 titik dalam RTH

Sebagian besar tanaman sebanyak 58\% dari total individu tanaman di Kompleks Olahraga Wiradada dikategorikan baik dalam meredam kebisingan. Beberapa tanaman berkategori baik ditanam secara linear dibatas tapak Kompleks Olahraga Wiradadaha seperti bintaro (Cebera odollam), kesambi (Schleichera oleosa), johar (Senna siamea), dan trembesi (Samanea saman). Tanaman berkategori baik pun menyebar hampir di setiap area Kompleks Olahraga Wiradadaha (Gambar 26).

Jumlah tanaman yang dikategorikan sedang cukup banyak dengan persentase $34 \%$ dari total individu. Tanaman berkategori sedang ini menyebar baik secara berkelompok maupun soliter di beberapa area. Sebagian besar tanaman berkategori sedang belum memenuhi kriteria berdaun tebal dan berdaun jarum (K2 dan K4).

Tabel 33 Penilaian aspek fungsi peredam kebisingan di Kompleks Olahraga Wiradadaha

\begin{tabular}{|c|c|c|c|c|c|c|c|}
\hline \multirow{2}{*}{ Nama ilmiah } & \multirow{2}{*}{$\begin{array}{l}\text { Nama } \\
\text { lokal }\end{array}$} & \multicolumn{4}{|c|}{$\begin{array}{l}\text { Kriteria fungsi peredam } \\
\text { kebisingan }\end{array}$} & \multirow{2}{*}{$\begin{array}{l}\text { Skor } \\
(\%)\end{array}$} & \multirow{2}{*}{$\begin{array}{c}\text { Kategor } \\
\mathrm{i}\end{array}$} \\
\hline & & $\mathrm{K} 1$ & $\mathrm{~K} 2$ & K3 & K4 & & \\
\hline $\begin{array}{l}\text { Acacia } \\
\text { auriculiformis }\end{array}$ & Akasia & 2 & 2 & 4 & 1 & 56 & Sedang \\
\hline Acacia longifolia & Akasia & 2 & 2 & 4 & 1 & 56 & Sedang \\
\hline Alstonia scholaris & Pulai & 4 & 3 & 4 & 1 & 75 & Baik \\
\hline
\end{tabular}


Tabel 33 Penilaian aspek fungsi peredam kebisingan di Kompleks Olahraga Wiradadaha (lanjutan)

\begin{tabular}{|c|c|c|c|c|c|c|c|}
\hline \multirow{2}{*}{ Nama ilmiah } & \multirow{2}{*}{ Nama lokal } & \multicolumn{4}{|c|}{$\begin{array}{c}\text { Kriteria fungsi peredam } \\
\text { kebisingan }\end{array}$} & \multirow{2}{*}{$\begin{array}{l}\text { Skor } \\
(\%)\end{array}$} & \multirow{2}{*}{ Kategor } \\
\hline & & $\mathrm{K} 1$ & K2 & K3 & K4 & & \\
\hline Bauhinia purpurea & Bunga kupu-kupu & 2 & 2 & 3 & 3 & 63 & Baik \\
\hline Butia capitata & Jelly palm & 2 & 3 & 1 & 2 & 50 & Sedang \\
\hline Casuarina sp. & Cemara & 4 & 4 & 2 & 4 & 88 & $\begin{array}{l}\text { Sangat } \\
\text { baik }\end{array}$ \\
\hline Cerbera odollam & Bintaro & 4 & 3 & 3 & 1 & 69 & Baik \\
\hline $\begin{array}{l}\text { Erythrina crista- } \\
\text { galli }\end{array}$ & Dadap merah & 2 & 3 & 3 & 1 & 56 & Sedang \\
\hline Felicium decipiens & Krei payung & 4 & 3 & 4 & 1 & 75 & Baik \\
\hline Ficus benjamina & Beringin & 3 & 3 & 3 & 1 & 63 & Baik \\
\hline Ficus elastica & Beringin karet & 2 & 3 & 3 & 1 & 56 & Sedang \\
\hline Ficus lyrata & Biola cantik & 4 & 2 & 4 & 1 & 69 & Baik \\
\hline $\begin{array}{l}\text { Leucaena } \\
\text { Zeucocephala }\end{array}$ & Lamtoro & 3 & 3 & 4 & 3 & 81 & $\begin{array}{l}\text { Sangat } \\
\text { baik }\end{array}$ \\
\hline Mangifera indica & Mangga & 3 & 2 & 4 & 1 & 63 & Baik \\
\hline Manilkara kaukii & Sawo kecik & 2 & 3 & 3 & 1 & 56 & Sedang \\
\hline $\begin{array}{l}\text { Maniltoa } \\
\text { grandiflora }\end{array}$ & Pohon sapu tangan & 3 & 2 & 4 & 1 & 63 & Baik \\
\hline Mimusoph elengi $L$. & Tanjung & 2 & 2 & 3 & 1 & 50 & Sedang \\
\hline $\begin{array}{l}\text { Morinda citrifolia } \\
\text { L. }\end{array}$ & Mengkudu & 3 & 2 & 2 & 1 & 50 & Sedang \\
\hline Muntingi calabura & Kersen & 4 & 3 & 2 & 3 & 75 & Baik \\
\hline $\begin{array}{l}\text { Ochroma } \\
\text { pyramidale }\end{array}$ & Balsa & 2 & 1 & 3 & 3 & 56 & Sedang \\
\hline Plumeria rubra & Kamboja & 1 & 1 & 3 & 1 & 38 & Buruk \\
\hline Polyalthia fragrans & Glodogan bulat & 2 & 2 & 3 & 1 & 50 & Sedang \\
\hline $\begin{array}{l}\text { Polyalthia } \\
\text { longifolia }\end{array}$ & Glodogan tiang & 4 & 2 & 2 & 1 & 56 & Sedang \\
\hline Pometia pinnata & Matoa & 3 & 3 & 2 & 1 & 56 & Sedang \\
\hline Psidium guajava & Jambu & 2 & 3 & 3 & 1 & 56 & Sedang \\
\hline Pterocapus indicus & Angsana & 3 & 2 & 4 & 3 & 75 & Baik \\
\hline Roystone regia & Palem raja & 1 & 2 & 1 & 2 & 38 & Buruk \\
\hline Samanea saman & Trembesi & 4 & 2 & 4 & 1 & 69 & Baik \\
\hline Schleichera oleosa & Kesambi & 2 & 2 & 3 & 3 & 63 & Baik \\
\hline Senna siamea & Johar & 3 & 2 & 4 & 1 & 63 & Baik \\
\hline Switenia mahogani & Mahoni & 3 & 3 & 4 & 1 & 69 & Baik \\
\hline $\begin{array}{l}\text { Syzygium } \\
\text { campanulatum }\end{array}$ & Pucuk merah & 4 & 2 & 2 & 1 & 56 & Sedang \\
\hline Tabebuia chrysant & Tabebuia & 2 & 3 & 3 & 3 & 69 & Baik \\
\hline Terminalia catappa & Ketapang & 2 & 3 & 4 & 1 & 63 & Baik \\
\hline Terminalia mantaly & Ketapang kencana & 2 & 2 & 3 & 1 & 50 & Sedang \\
\hline Wodyetia bifurcata & Palem ekor tupai & 1 & 3 & 1 & 2 & 44 & Sedang \\
\hline
\end{tabular}


(1980

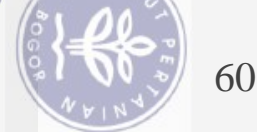

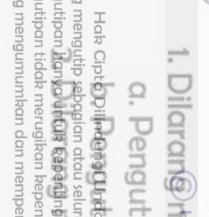

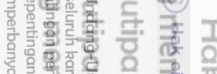

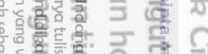

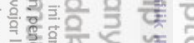

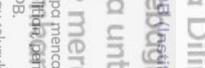

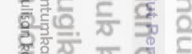

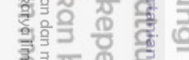

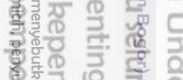

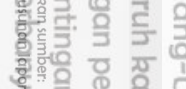

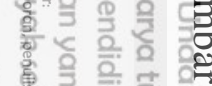

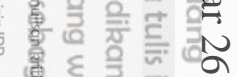

율 응

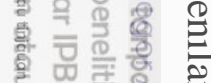

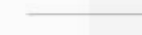

(ด)

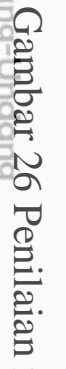

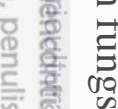

일 $\frac{1}{\frac{1}{6}}$

害

흘 할

ॠ

贾

气

을 항

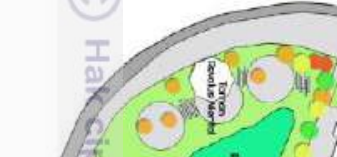

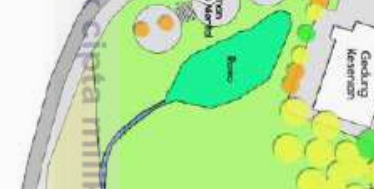

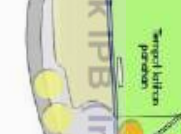

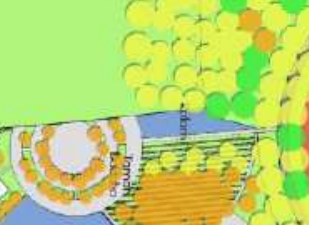
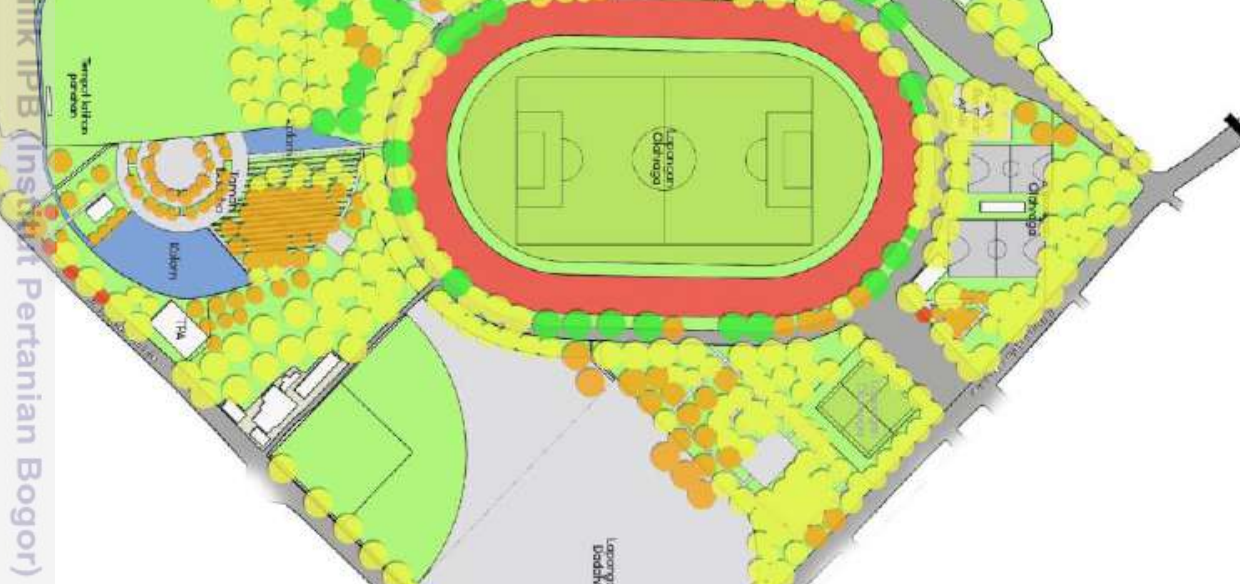

器

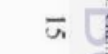

z

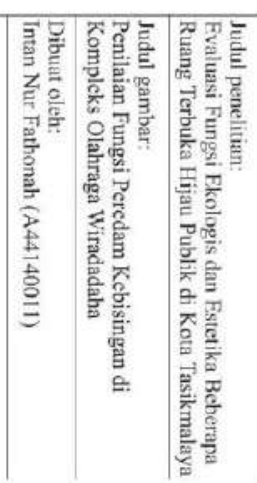

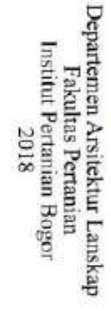

8888

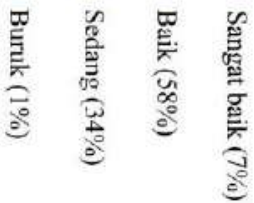


Kompleks Olahraga Wiradadaha tidak dikelilingi oleh jalan dengan aktivitas yang tinggi seperti di Alun-alun dan Taman Kota. Sebelah Timur Laut hingga Timur Kompleks Olahraga Wiradadaha merupakan gedung-gedung serbaguna dan area Universitas Pendidikan Indonesia cabang Kota Tasikmalaya. Sebelah Tenggara Kompleks Olahraga Wiradadaha merupakan pertokoan. Sebelah Selatan hingga Utara Kompleks Olahraga Wiradadaha berbatasan langsung dengan permukiman. Rendahnya aktivitas di sekitar Kompleks Wiradadaha menyebabkan rendahnya pula tingkat kebisingan di luar tapak.

Perbedaan pola penanaman setiap segmen di Kompleks Olahraga Wiradadaha dengan kondisi sekitarnya memperlihatkan kemampuan peredaman kebisingan yang berbeda pula. Titik P1 merupakan pengukuran kebisingan di segmen 1. Pola penanaman di segmen 1 tidak terlalu rapat karena di dominasi oleh perkerasan. Jalan Lingkar Dadaha di sekitar segmen 1 cukup sepi karena dikelilingi permukiman. Kebisingan di Tabel 34 menunjukkan rata-rata tingkat kebisingan yang cukup rendah di titik P1 di dalam maupun di luar tapak.

Titik P2 ditutupi oleh tanaman tua yang tajuknya rapat. Jalan Wiradadaha yang berada di Barat Laut segmen 2 merupakan jalan masuk menuju Kompleks Olahraga Wiradadaha sehingga cukup ramai oleh kendaraan di waktu-waktu tertentu. Titik P2 yang berada di segmen 2 lebih efektif meredam kebisingan bila dilihat dari rata-rata tingkat kebisingannya di dalam tapak.

Titik P3 didominasi oleh area perkerasan yang luas. Titik P3 di segmen 3 berbatasan dengan jalanan lebar sehingga pada waktu-waktu tertentu kendaraan meningkatkan kecepatannya dan menimbulkan kebisingan. Pola penanaman tanaman secara linear di sekeliling segmen 3 belum cukup efektif dalam meredam kebisingan.

Tabel 34 Hasil pengukuran kebisingan di Kompleks Olahraga Wiradadaha

\begin{tabular}{lcccccc}
\hline \multirow{2}{*}{ Waktu } & \multicolumn{3}{c}{ Dalam RTH } & \begin{tabular}{c} 
Rata-rata \\
dalam RTH \\
\cline { 2 - 4 }$(\mathrm{dB})$
\end{tabular} & $\begin{array}{c}\text { Rata-rata } \\
\text { luar RTH } \\
(\mathrm{dB})\end{array}$ & $\begin{array}{c}\text { Selisih } \\
(\mathrm{dB})\end{array}$ \\
\hline Pagi & 60.1 & 64.3 & 64.6 & 63.0 & 66.9 & 3.9 \\
Siang & 59.8 & 63.8 & 65.3 & 63.0 & 65.7 & 2.7 \\
Sore & 61.8 & 48.1 & 67.2 & 59.1 & 68.0 & 8.9 \\
Rata-rata & 60.6 & 58.8 & 65.7 & 61.7 & 66.9 & 5.2 \\
\hline
\end{tabular}

* P1, P2, dan P3 merupakan rata-rata data dari waktu pengambilan data di 3 titik dalam RTH

Hasil penilaian secara keseluruhan menunjukkan bahwa Kompleks Olahraga Wiradadaha memiliki skor tertinggi namun masih dalam kategori sedang (Tabel 35). Hasil penilaian tersebut sejalan dengan hasil pengukuran yang menunjukkan bahwa rata-rata kebisingan di Kompleks Olahraga Wiradadaha merupakan terendah dibandingkan dengan kebisingan di Alun-alun dan Taman Kota. Selisih kebisingan di dalam dan luar tapak di setiap lokasi yang tinggi menunjukkan bahwa RTH memang dapat meredam kebisingan. RTH ini dimanfaatkan pula sebagai tempat rekreasi. Bila dibandingkan berdasarkan baku mutu kebisingan tempat rekreasi, ketiga RTH masih dalam kebisingan yang sesuai karena baku mutu kebisingan tempat rekreasi yaitu $70 \mathrm{~dB}$ namun semakin rendah tingkat kebisingan yang didengar maka akan semakin baik kenyamanan yang dirasakan pengunjung. 
Persepsi pengunjung menyatakan bahwa kebisingan di Alun-alun dan Kompleks Olahraga Wiradadaha berada pada tahap sedang. Sebagian besar responden memilih pilihan bising untuk tingkat kebisingan di Taman Kota (Gambar 27). Penataan tanaman yang sesuai perlu diperhatikan pula sehingga tanaman dapat berfungsi dengan baik sebagai peredam kebisingan.

Tabel 35 Persentase penilaian tanaman fungsi peredam kebisingan

\begin{tabular}{|c|c|c|c|c|c|c|c|}
\hline $\begin{array}{c}\text { Lokasi } \\
\frac{I}{\varrho}\end{array}$ & Kategori & $\begin{array}{c}\text { Jumlah } \\
\text { Jenis }\end{array}$ & $\begin{array}{c}\text { Jumlah } \\
\text { Individu }\end{array}$ & $\begin{array}{c}\text { Persentase } \\
\text { terhadap } \\
\text { total jenis } \\
(\%)\end{array}$ & $\begin{array}{c}\text { Persentase } \\
\text { terhadap } \\
\text { total } \\
\text { individu }(\%)\end{array}$ & Skor & Kategori \\
\hline \multirow{4}{*}{ Alun-alun } & Sangat baik & 1 & 1 & 6 & 1 & \multirow{4}{*}{232} & \multirow{4}{*}{ Sedang } \\
\hline & Baik & 8 & 67 & 44 & 32 & & \\
\hline & Sedang & 8 & 132 & 44 & 64 & & \\
\hline & Buruk & 1 & 7 & 6 & 3 & & \\
\hline \multirow{4}{*}{ TamanKota } & Sangat baik & 1 & 11 & 13 & 12 & \multirow{4}{*}{242} & \multirow{4}{*}{ Sedang } \\
\hline & Baik & 3 & 36 & 38 & 18 & & \\
\hline & Sedang & 4 & 43 & 50 & 70 & & \\
\hline & Buruk & 0 & 0 & 0 & 0 & & \\
\hline \multirow{4}{*}{$\begin{array}{l}\quad \text { Kompleks } \\
\text { Olahraga } \\
\text { Wiradadaha }\end{array}$} & Sangat baik & 2 & 63 & 5 & 7 & \multirow{4}{*}{272} & \multirow{4}{*}{ Sedang } \\
\hline & Baik & 16 & 509 & 43 & 58 & & \\
\hline & Sedang & 16 & 292 & 43 & 34 & & \\
\hline & Buruk & 2 & 6 & 5 & 1 & & \\
\hline
\end{tabular}

Tabel 36 Rata-rata kebisingan Alun-alun, Taman Kota, dan Kompleks Olahraga Wiradadaha

\begin{tabular}{|c|c|c|c|c|c|c|}
\hline \multirow[b]{2}{*}{ Lokasi Penelitian } & \multicolumn{3}{|c|}{ Dalam RTH } & \multirow{2}{*}{$\begin{array}{c}\text { Rata- } \\
\text { rata } \\
\text { dalam } \\
\text { RTH } \\
(\mathrm{dB})\end{array}$} & \multirow{2}{*}{$\begin{array}{l}\text { Rata- } \\
\text { rata } \\
\text { luar } \\
\text { RTH } \\
(\mathrm{dB}) \\
\end{array}$} & \multirow[b]{2}{*}{$\begin{array}{l}\text { Selisih } \\
(\mathrm{dB})\end{array}$} \\
\hline & $\mathrm{P} 1 *(\mathrm{~dB})$ & $\mathrm{P} 2 *(\mathrm{~dB})$ & $\mathrm{P} 3 *(\mathrm{~dB})$ & & & \\
\hline Alun-alun & 66.1 & 66.0 & 62.3 & 64.8 & 68.6 & 3.8 \\
\hline Taman Kota & 68.2 & 68.1 & - & 68.2 & 72.4 & 4.2 \\
\hline Kompleks Olahraga Wiradadaha & 60.6 & 58.8 & 65.7 & 61.7 & 66.9 & 5.2 \\
\hline
\end{tabular}

* P1, P2, dan P3 merupakan rata-rata data dari pengulangan waktu di 2/3 titik dalam RTH

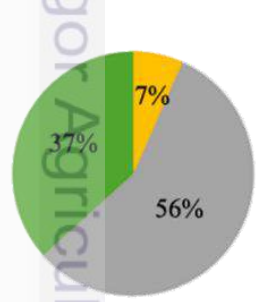

(a)

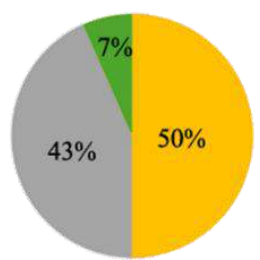

(b)

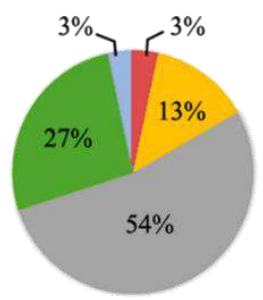

(c)

Gambar 27 Persentase persepsi responden tentang kebisingan di (a) Alun-alun, (b) Taman Kota, dan (c) Kompleks Olahraga Wiradadaha 


\section{Penilaian THI}

Kenyamanan thermal merupakan salah satu hal yang ingin dicapai dalam pembuatan suatu kawasan, salah satunya adalah RTH. Kenyamanan thermal ini dapat dinilai dengan metode THI. Menurut beberapa penelitian indeks kenyamanan paling sesuai berada pada kisaran 20-27 (Mulyana, Laras, Budi 2003; Emmanuel 2005). Mengacu kepada penelitian-penilitian sebelumnya, THI di ketiga lokasi penelitian masih dalam rentang standar yang sesuai (Tabel 39).

Selisih antara THI di luar dan dalam tapak ketiga lokasi berada pada kisaran 0.3-1.3. Selisih tersebut menandakan kenyamanan thermal di dalam tapak masih lebih tinggi daripada di luar tapak meskipun kondisinya tidak berbeda jauh. Kompleks Olahraga Wiradadaha memiliki THI yang paling rendah dengan nilai 25.6 yang berarti Kompleks Olahraga Wiradadaha dinilai memiliki kenyamanan thermal terbaik (Tabel 37). THI di Taman Kota sama besar dengan THI Alun-alun yaitu 26.1. Mengacu kepada penelitian sebelumnya, ketiga RTH masih dalam standar kenyamanan thermal yang ideal.

Pencapaian kondisi kenyamanan thermal di ketiga RTH juga sejalan dengan hasil penilaian tanaman khususnya dalam fungsi modifikasi suhu dan kontrol kelembaban. Kompleks Olahraga Wiradadaha sebagai RTH yang dinilai paling nyaman mendapat kategori baik dalam fungsi modifikasi suhu dan kontrol kelembaban. Alun-alun dan Taman Kota masih berada di kategori sedang dalam fungsi modifikasi suhu dan baik dalam fungsi kontrol kelembaban sehingga nilai THI kedua RTH masih cukup tinggi.

Peningkatan kenyamanan thermal dapat dilakukan dengan penambahan tanaman yang sesuai dan komposisi tanaman yang benar. Penanaman 'forest park' atau taman yang didominasi oleh pohon evergreen, yang dapat menambah luas bayangan dan meningkatkan kelembaban, lebih direkomendasikan di daerah tropis (Brown, Jennifer, Natasha, Sanda 2015). Penanaman dengan pola mengelompok juga diutamakan karena dapat menurunkan suhu lebih rendah (Abreu-Harbich, Labaki, dan Matzarakis 2015). Pemilihan dan pengaturan tata letak softscape dan hardscape yang tepat menjadi kunci bagaimana sebuah RTH dapat meningkatkan kenyamanan yang nyata (Brown dan Gillespie 1995).

Tabel 37 Penilaian THI di Alun-alun, Taman Kota, dan Kompleks Olahraga Wiradadaha

\begin{tabular}{|c|c|c|c|c|c|c|c|}
\hline \multirow[b]{2}{*}{ Lokasi } & \multicolumn{2}{|c|}{ Dalam RTH } & \multicolumn{2}{|c|}{ Luar RTH } & \multirow[b]{2}{*}{$\begin{array}{c}\text { THI } \\
\text { dalam } \\
\text { RTH }\end{array}$} & \multirow[b]{2}{*}{$\begin{array}{l}\text { THI } \\
\text { luar } \\
\text { RTH }\end{array}$} & \multirow[b]{2}{*}{ Selisih } \\
\hline & $\begin{array}{c}\mathrm{T} \\
\text { Rata- } \\
\text { rata } \\
\left({ }^{\circ} \mathrm{C}\right)\end{array}$ & $\begin{array}{c}\text { RH } \\
\text { Rata- } \\
\text { rata } \\
(\%)\end{array}$ & $\begin{array}{c}\mathrm{T} \\
\text { Rata- } \\
\text { rata } \\
\left({ }^{\circ} \mathrm{C}\right)\end{array}$ & $\begin{array}{c}\text { RH } \\
\text { Rata- } \\
\text { rata }(\%)\end{array}$ & & & \\
\hline Alun-alun & 28.2 & 63 & 30.4 & 51 & 26.1 & 27.4 & 1.3 \\
\hline Taman Kota & 28.2 & 62.5 & 29.5 & 57.3 & 26.1 & 27.0 & 0.9 \\
\hline Kompleks Olahraga Wiradadaha & 27.5 & 65.6 & 28.2 & 59.3 & 25.6 & 25.9 & 0.3 \\
\hline
\end{tabular}




\section{Evaluasi Kualitas Estetika Lanskap}

\section{Alun-alun}

Terdapat 23 buah foto lanskap yang dijadikan sampel evaluasi kualitas estetika di Alun-alun. Foto-foto tersebut tersebar merata mewakili lanskap setiap area di Alun-alun. Hasil penilaian lanskap oleh responden secara keseluruhan dikelompokan menjadi estetika tinggi, sedang, dan rendah (Gambar 28). Sebagian besar lanskap Alun-alun termasuk ke dalam kelompok estetika sedang. Penilaian tertinggi untuk Alun-alun adalah lanskap 4 (SBE 40.2). Lanskap dengan nilai SBE tertinggi berarti lanskap tersebut secara visual dinilai indah dan disukai oleh responden. Lanskap 13 mendapat nilai terendah dengan nilai SBE -70. Lanskap berkategori estetika tinggi mengarah ke area tugu dan ada juga yang mengarah kepada deretan tanaman hias (Gambar 29). Lanskap berkategori estetika rendah rata-rata menunjukkan pemandangan perkerasan dengan sedikit tanaman dan sampa⿳亠口冋 yang tercecer.

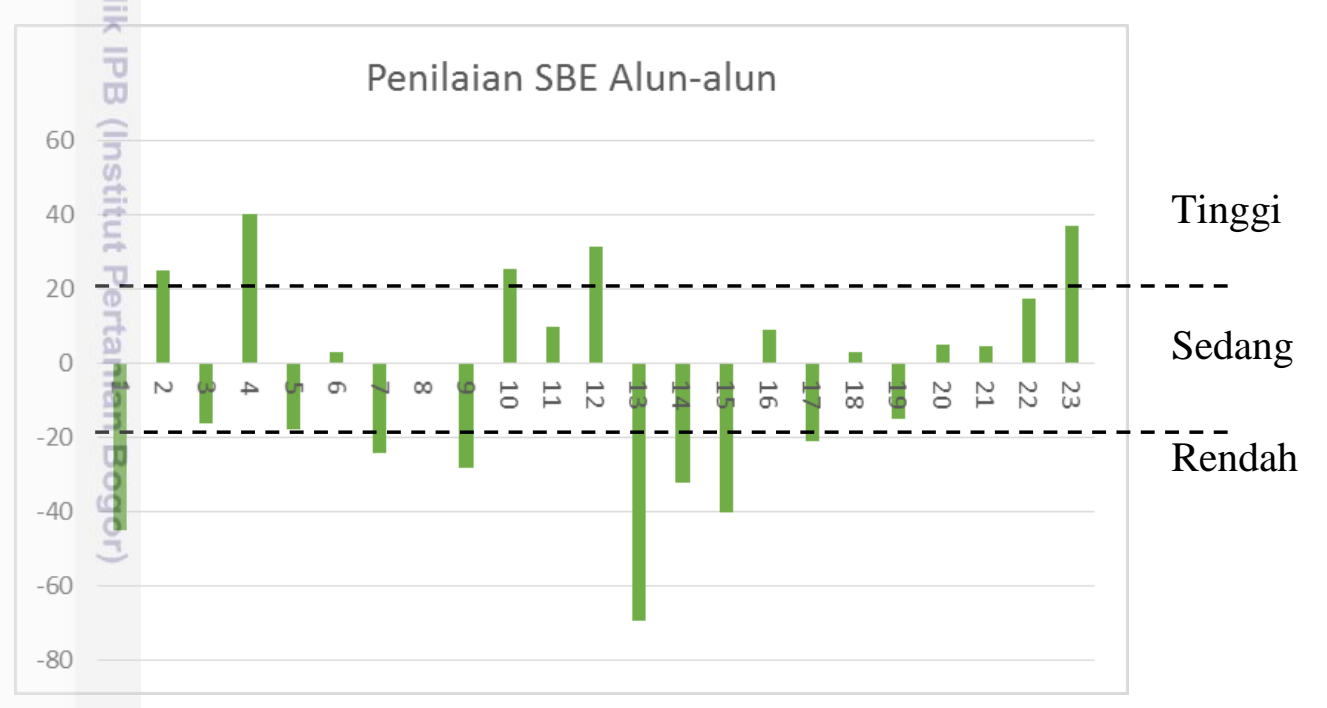

Gambar 28 Grafik nilai SBE pada Alun-alun

Lanskap 4 sebagai lanskap dengan nilai SBE tertinggi menerapkan prinsip desain kontras dari tugu dan variasi dari warna dan tekstur. Meskipun begitu, pengelolaan dalam mempertahankan desain tampak masih kurang baik. Hal tersebut terlihat dari kondisi tanaman penutup tanah seperti lili paris (Cholorophytum comosum) dan spider lili (Hymenocallis speciosa) yang perlu penyulaman. Pemangakasan pada pucuk merah (Syzygium campanulatum) belum seragam (Gambar 30).

Lanskap 13 mendapat nilai SBE terendah. Lanskap 13 telah menerapkan prinsip desain balance (keseimbangan) dengan meletakan dua pohon krei payung (Felicium decipiens) di sisi gerbang namun masih kurang diberikan aksen lain yang dapat-memperindah lanskap. Pengelolaan yang kurang juga terlihat dari rusaknya perkerasan, perlunya pengecatan pagar, dan pembersihan. Gerbang Alun-alun di sebelah Utara ini juga sering dijadikan tempat pedagang singgah. 
(16)

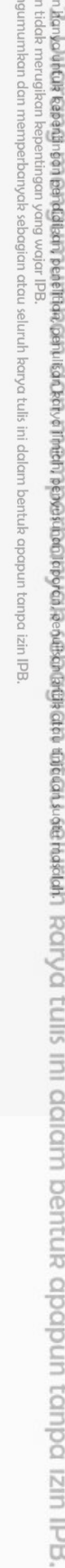

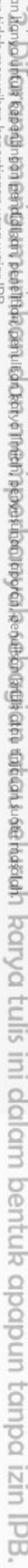

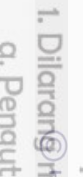

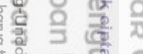

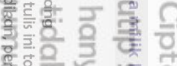

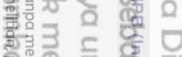

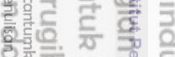

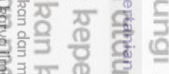

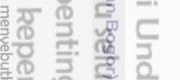

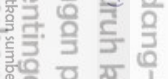

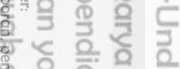

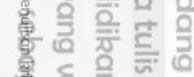
हो 흘 西帮 弯. के 高等
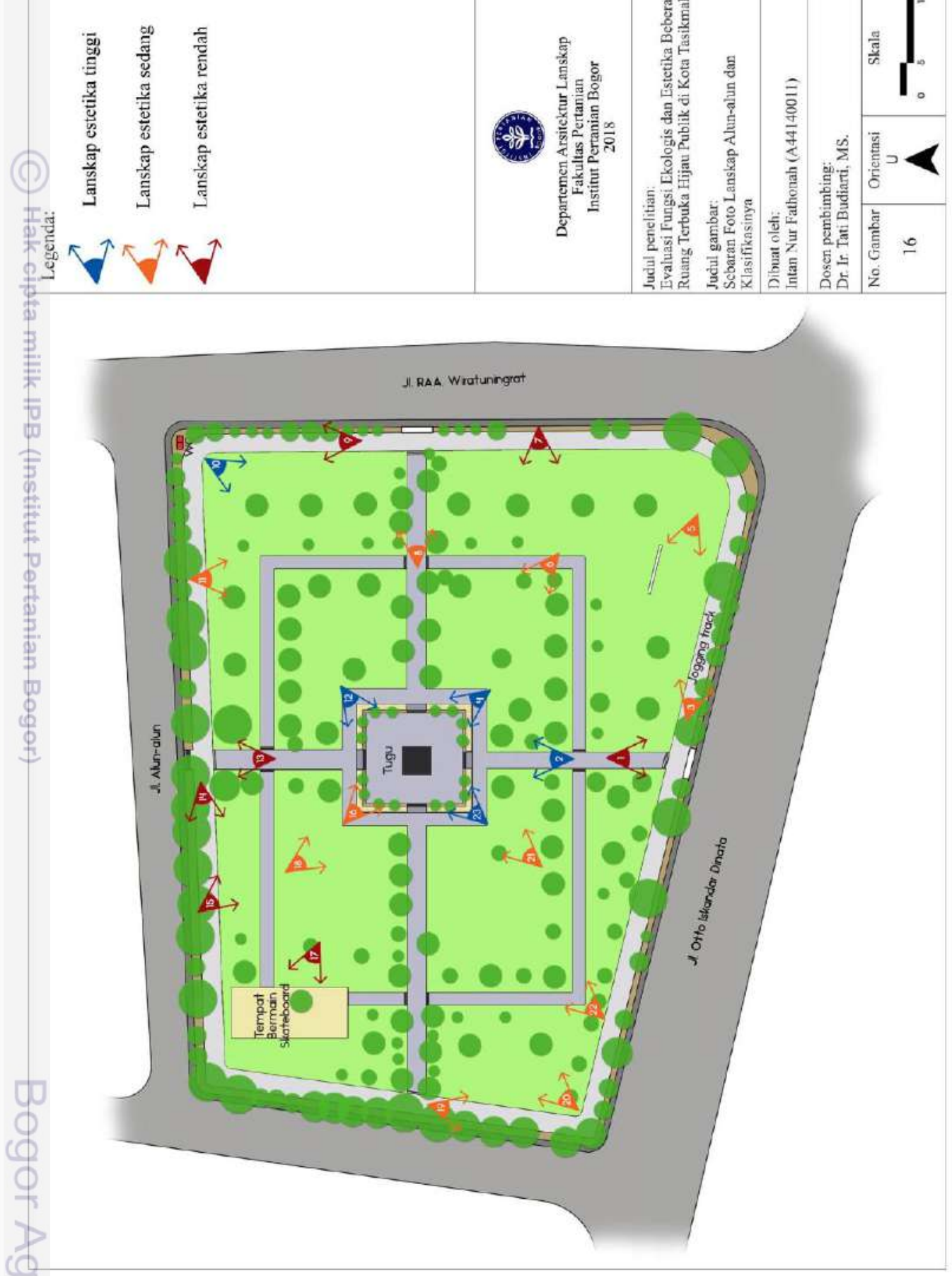


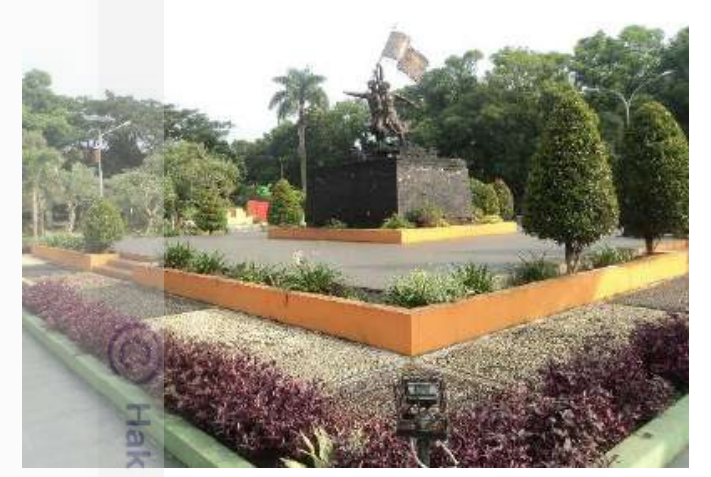

(a)

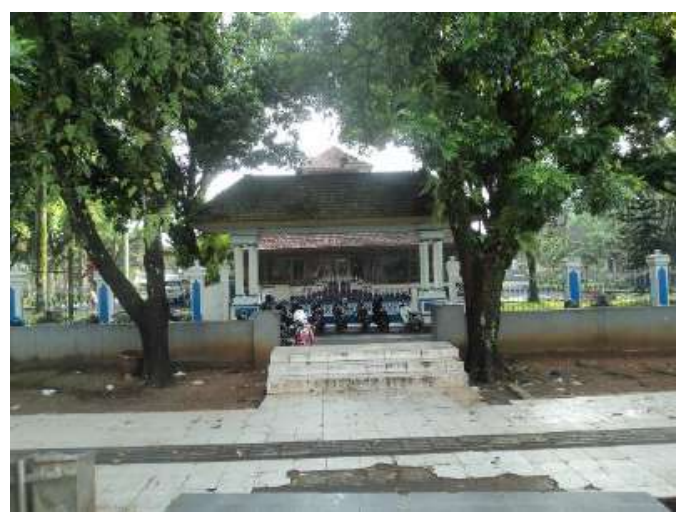

(b)

Gambar 30 (a) Lanskap 4 (nilai SBE tertinggi) dan (b) Lanskap 13 (nilai SBE terendah)

\section{Taman Kota}

Foto lanskap yang diambil sebagai contoh penilaian di Taman Kota terdiri dari 22 foto lanskap. Hasil keseluruhan dari penilaian lanskap oleh responden menunjukkan hanya sedikit lanskap yang memperoleh nilai tinggi (Gambar 31). Lanskap dengan nilai sedang lebih mendominasi dengan jumlah 15 lanskap. Lanskap dengan nilai rendah yaitu sebanyak 5 lanskap.

Lanskap dengan estetika tinggi mengarah kepada pemandangan gazebo dengan perkerasan yang dihiasi rangkai tanaman penutup tanah. Lanskap dengan estetika sedang mengarah kepada berbagai pemandangan seperti ampiteater, tempat bermain anak, parklet, dan area berumput. Lanskap dengan estetika rendah lebih banyak mengarah kepada pemandangan plaza, area berumput dalam sudut pandang lain, dan tugu peresmian Kota Tasikmalaya (Gambar 32).

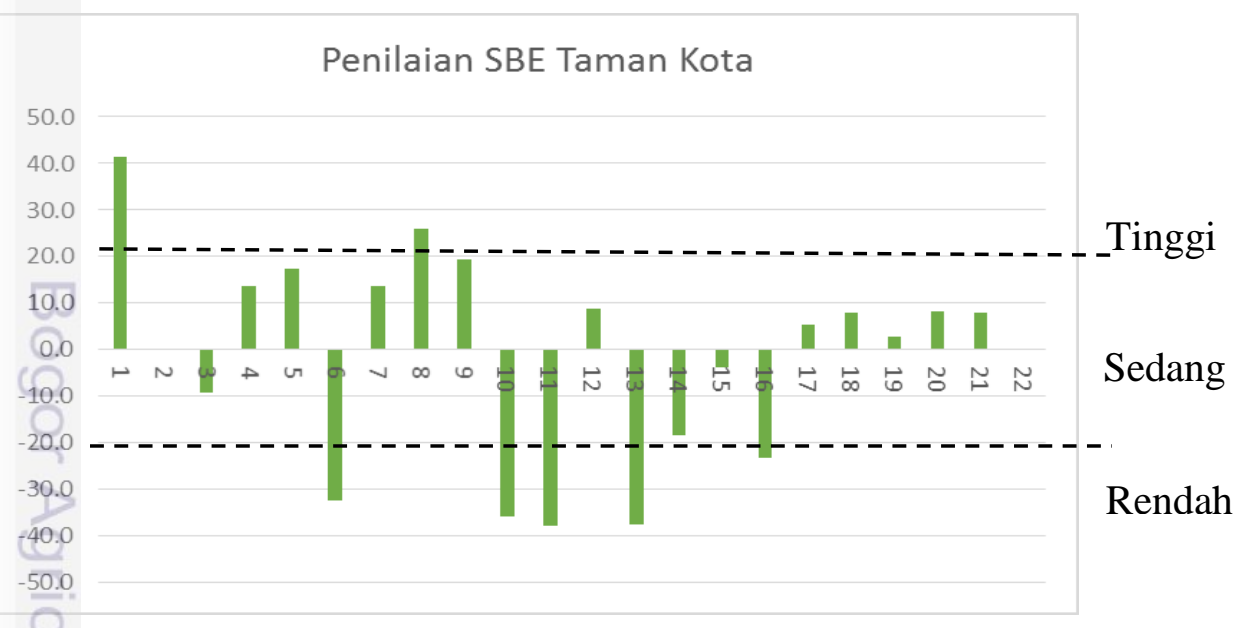

Gambar 31 Grafik nilai SBE pada Taman Kota 
(16)

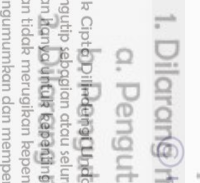


Lanskap 1 mendapat nilai SBE tertinggi sebesar 41.4. Prinsip desain yang diterapkan di Lanskap 1 yaitu kontras dari kimeng (Ficus microcarpa) serta variasi dari jawer kotok (Coleus sp.) dan duranta (Duranta repens) yang ditanam secara berulang di sepanjang perkerasan (Gambar 33).

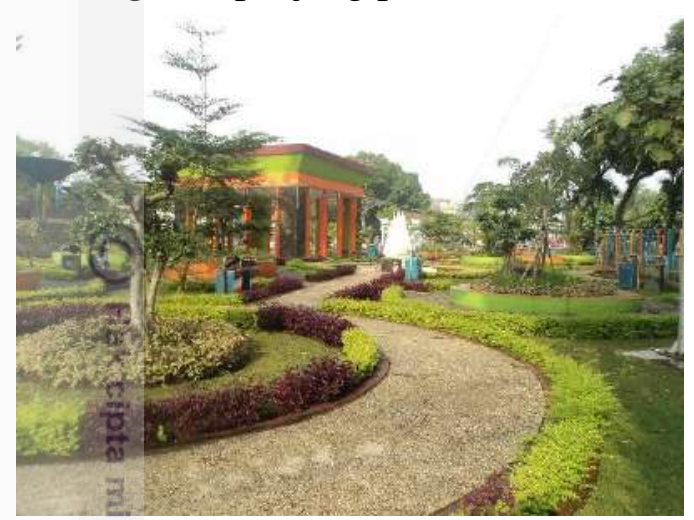

(a)

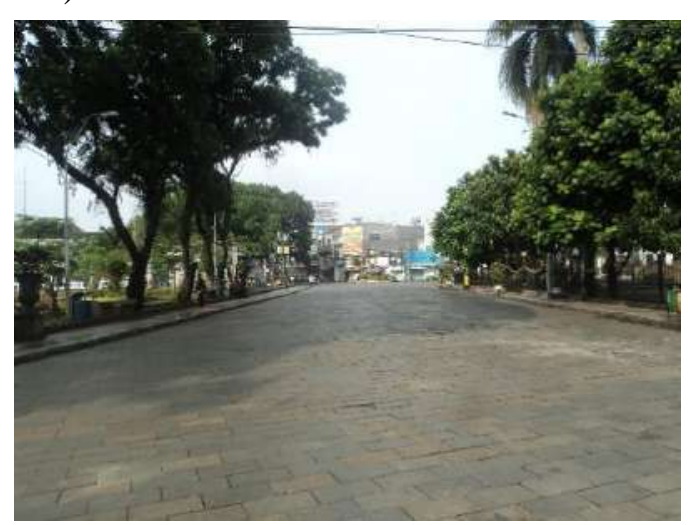

(b)

Gambar 33 (a) Lanskap 1 (nilai SBE tertinggi) dan (b) Lanskap 11 (nilai SBE terendah)

Lanskap 11 mendapat nilai SBE terendah yaitu sebesar -37.8. Foto Lanskap 11 menunjukkan area plaza yang berada di antara taman dengan Masjid Agung. Lanskap 11 memang sengaja didesain sebagai ruang terbuka sehingga bisa digunakan beragam aktivitas oleh pengunjung. Nilai yang diberikan rendah bisa disebabkan karena kurangnya aksen yang memperindah lanskap. Latar belakang lanskap yang merupakan pertokoan juga mempengaruhi nilai estetika dari lanskap.

\section{Kompleks Olahraga Wiradadaha}

Jumlah foto lanskap yang diambil sebagai sampel penilaian di Kompleks Olahraga Wiradadaha adalah 33 foto lanskap. Sampel yang diambil lebih banyak karena luas tapak yang lebih luas dibandingkan Alun-alun dan Taman Kota. Hasil penilaian secara keseluruhan menunjukkan bahwa kualitas estetika di Kompleks Olahraga Wiradadaha sangat rendah. Tidak ada lanskap yang mendapat nilai tinggi. Lanskap dengan nilai rendah mendominasi dengan jumlah 24 lanskap (Gambar 34).

Penilaian SBE Kompleks Olahraga Wiradadaha

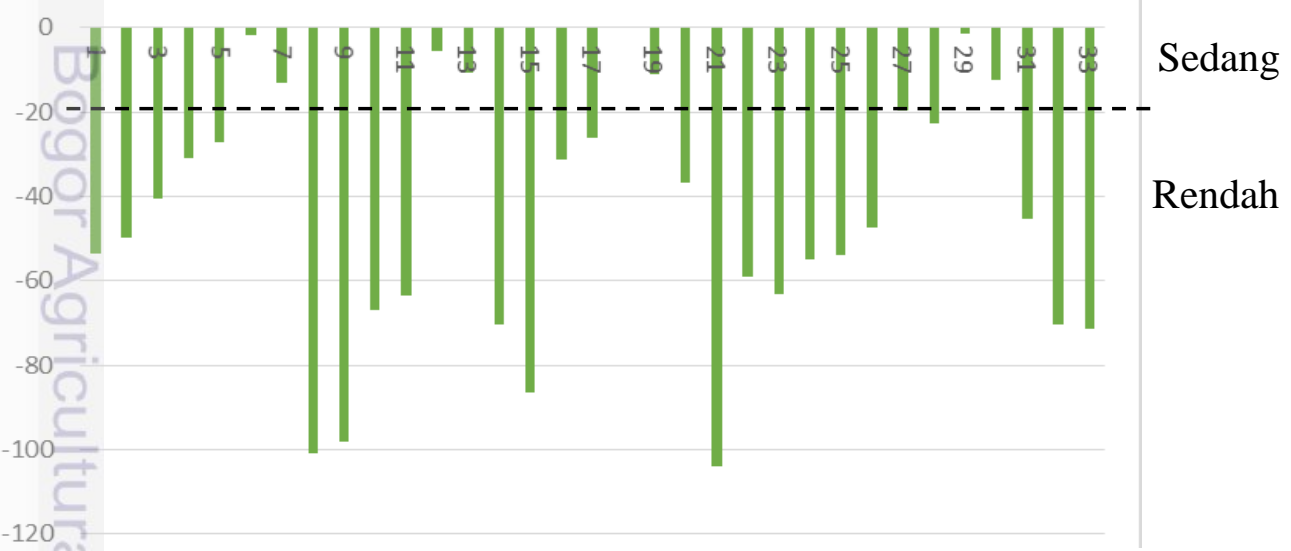

Gambar 34 Grafik nilai SBE pada Kompleks Olahraga Wiradadaha 


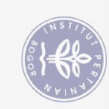

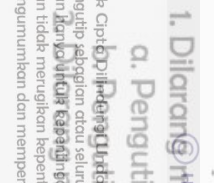

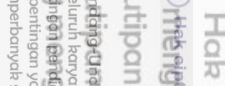

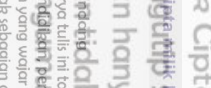

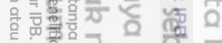

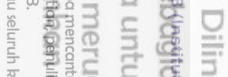

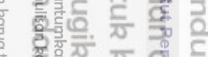

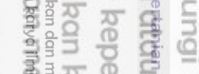

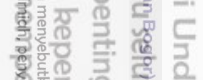

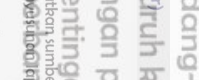

ह5

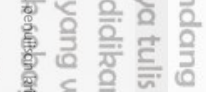

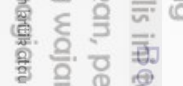

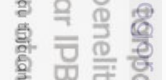

今.

表旁

这焉

这

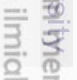

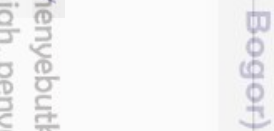

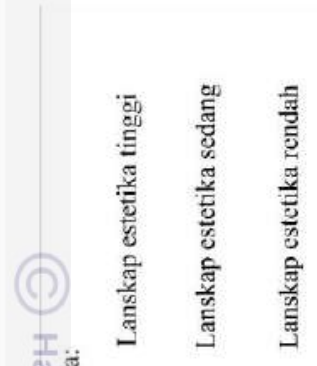

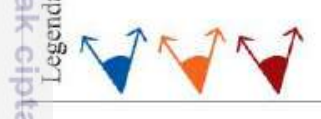

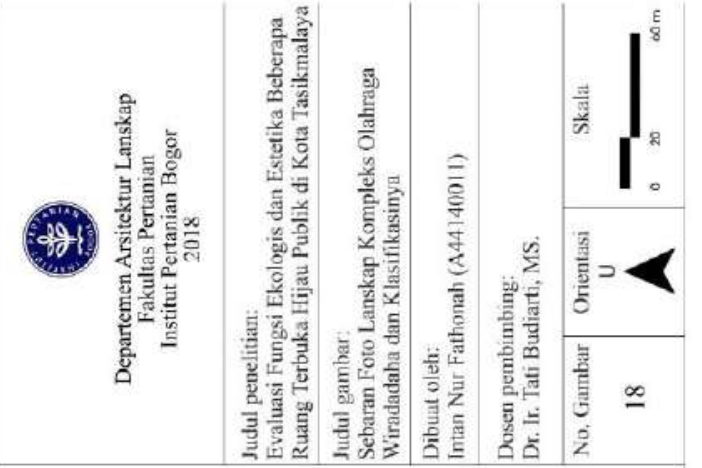

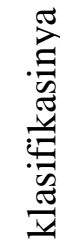

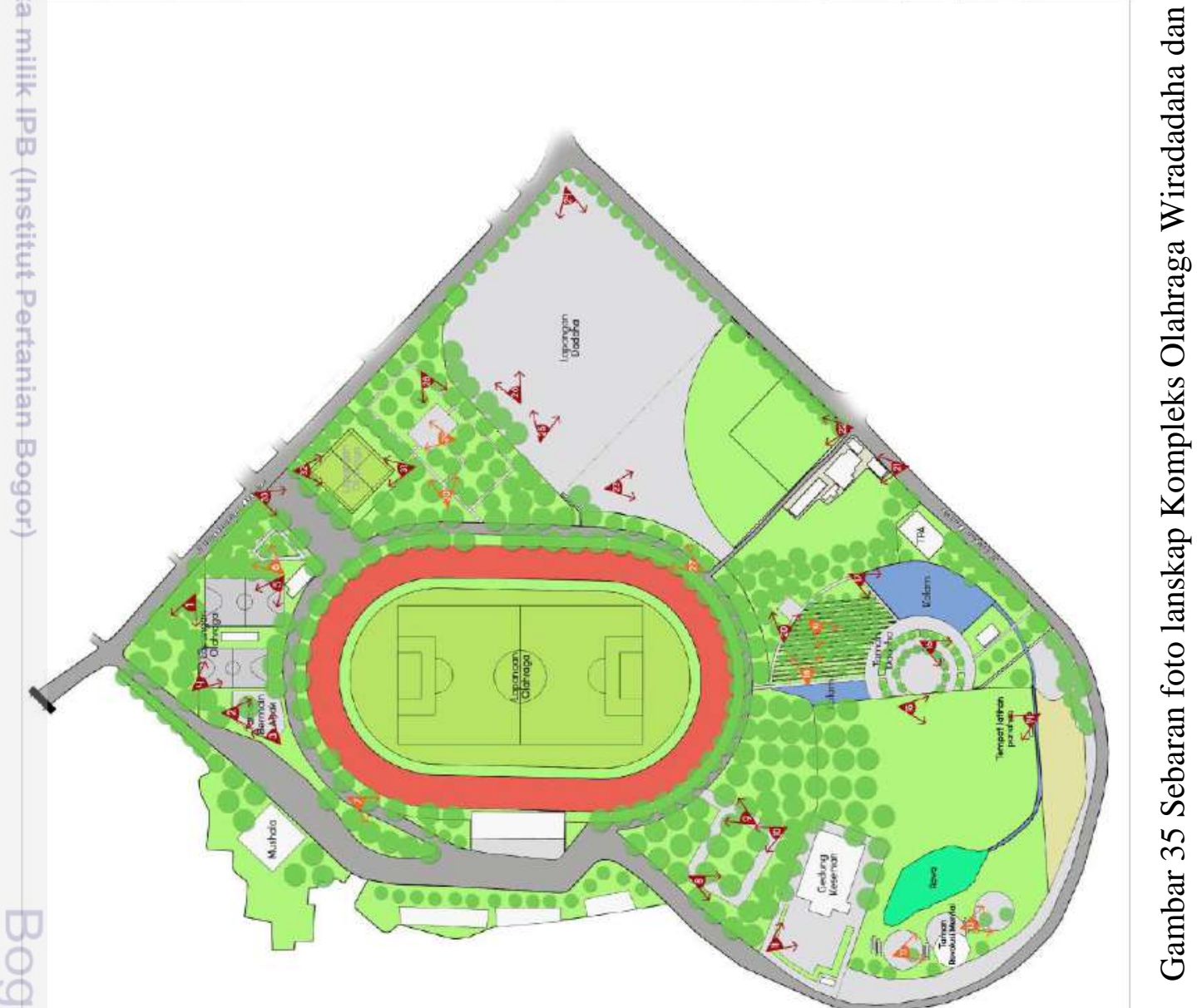


Lanskap yang masuk ke dalam estetika rendah tersebar hampir di semua area Kompleks Olahraga Wiradadaha. Lanskap estetika sedang hanya berada di beberapa area seperti Taman Dadaha, Taman Revolusi Mental, hutan kota, dan taman terapi (Gambar 35). Rendahnya nilai estetika lanskap di Kompleks Olahraga Wiradadaha lebih karena kurangnya perawatan, khususnya pada perkerasan. Tanaman terutama pepohonan di Kompleks Olahraga Wiradadaha justru menambah nilai estetika seperti pada lanskap 7 dan 27 yang memperlihatkan jalur jogging yang dibingkai oleh tajuk trembesi (Samanea saman) termasuk ke dalam kelompok estetika sedang.

Nilai SBE tertinggi didapatkan oleh Lanskap 18 dengan nilai 0 yang masuk ke dalam kelompok estetika sedang sekaligus menjadi standar estetika dalam persepsi responden. Lanskap 18 menerapkan prinsip desain pengulangan pada elemen lanskapnya seperti pohon dadap merah (Erythrina crista-galli), bangku taman, dan jalur hijau rerumputannya (Gambar 36). Penerapan prinsip pengulangan belum diikuti oleh prinsip-prinsip desain lainnya seperti keseimbangan dan kesatuan.

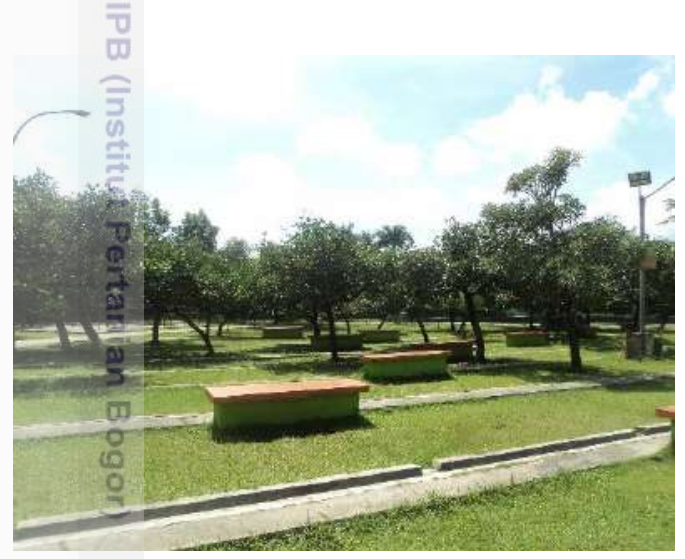

(a)

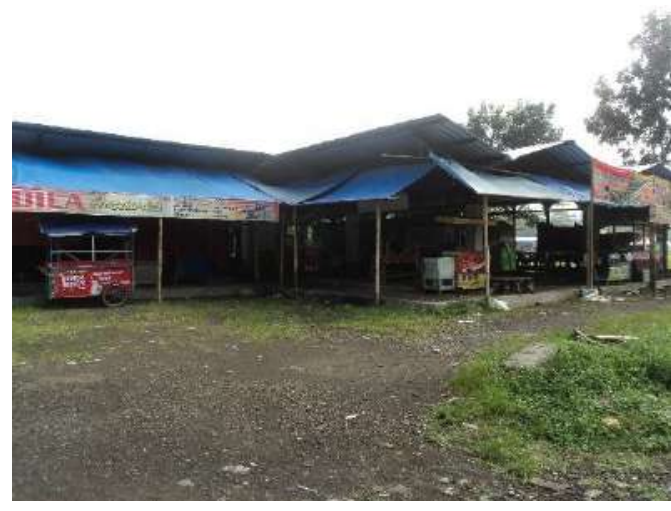

(b)

Gambar 36 (a) Lanskap 18 (nilai SBE tertinggi) dan (b) Lanskap 21 (nilai SBE terendah)

Lanskap 21 mendapat nilai SBE terendah yaitu sebesar -104.1. Lanskap 21 merupakan area relokasi pedagang yang disediakan oleh pengelola. Usaha relokasi pedagang dilakukan agar pedagang dapat tertib dan terpusat. Lokasi yang disediakan sangat sederhana, tertutup, dan tidak didesain dengan menarik sehingga pengunjung jarang ada yang datang dan pedagang pun enggan untuk dialokasikan ke tempat tersebut.

\section{Persepsi dan Preferensi Responden}

Persepsi dan preferensi responden diambil dari hasil wawancara dengan kuesioner kepada 90 orang pengunjung yang diambil dari masing-masing RTH sebanyak 30 orang. Data yang didapatkan dari hasil wawancara meliputi kararteristik responden, persepsi, serta preferensi responden mengenai kenyamanan dan estetika RTH yang dikunjungi. Persepsi dan preferensi responden diharapkan dapat memberi gambaran mengenai kondisi yang dirasakan pengunjung pada 
umumnya ketika berada di RTH dan dapat mewakili preferensi pengunjung secara keseluruhan mengenai RTH yang dikunjungi.

\section{Karakteristik responden}

Data karakteristik responden diperlukan untuk mengetahui karakteristik pengunjung pada masing-masing RTH secara keseluruhan. Karakteristik responden juga berpengaruh terhadap pengetahuan responden mengenai fungsi RTH dan preferensinya terhadap RTH. Data yang ditanyakan antara lain jenis kelamin, asal daerah, usia, pekerjaan, pendidikan terakhir, dan tujuan kunjungan.

Berdasarkan hasil wawancara, sebagian besar responden di masing-masing RTH merupakan perempuan (Gambar 37). Sebagian besar responden berasal dari Tasikmalaya (Gambar 38). Beberapa responden yang berasal dari luar kota di antaranya berasal dari Ciamis, Banjar, Semarang, Bandung, Cianjur, dan Sumedang. Responden dari ketiga RTH didominasi oleh responden berumur dewasa awal yaitu umur 18-40 tahun (Gambar 39).

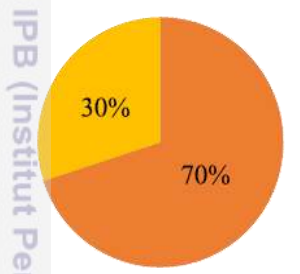

(a)

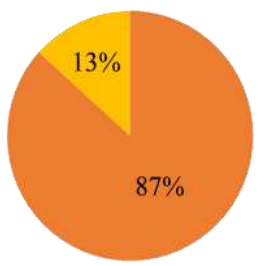

(b)

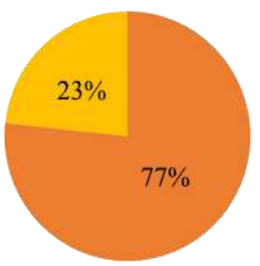

(c)
Perempuan

Laki-laki

Gambar 37 Persentase jenis kelamin responden di (a) Alun-alun, (b) Taman Kota, dan (c) Kompleks Olahraga Wiradadaha

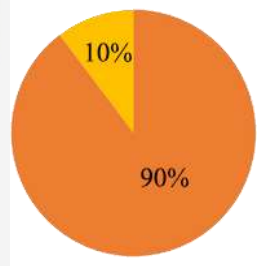

(a)

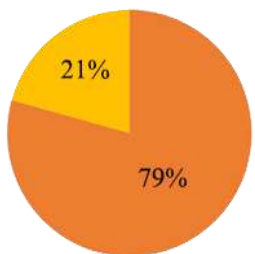

(b)

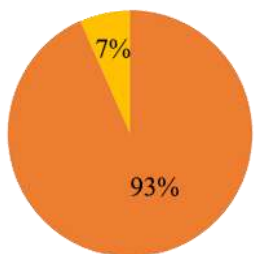

(c)

Gambar 38 Persentase daerah asal responden di (a) Alun-alun, (b) Taman Kota, dan (c) Kompleks Olahraga Wiradadaha

Responden di Alun-alun banyak dikunjungi oleh pelajar yaitu sebanyak $23 \%$ dari total responden. Alun-alun dikelilingi oleh beberapa sekolah sehingga Alun-alun lebih mudah dijangkau oleh pelajar. Taman Kota didominasi oleh responden dengan pekerjaan ibu rumah tangga sebesar 27\%. Taman Kota memiliki area tempat bermain anak sehingga ibu dan anaknya sering datang untuk berekreasi di sana. Kompleks Olahraga Wiradadaha banyak dikunjungi oleh responden mahasiswa yaitu sebesar $43 \%$ dari total responden (Gambar 40). Masing-masing RTH dikunjungi oleh responden dengan pekerjaan lain-lain yang terdiri dari pensiunan, guru, dan belum bekerja. 


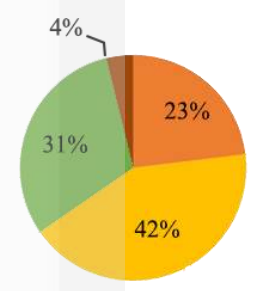

(a)

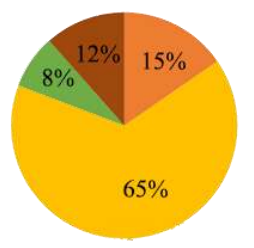

(b)

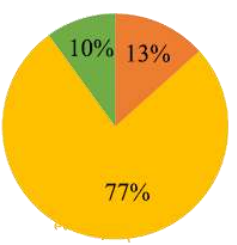

(c)
- Remaja (<18 tahun)

- Dewasa awal (18-40 tahun)

- Dewasa madya (41-60 tahun)

- Lansia (>60 tahun)

Gambar 39 Persentase usia responden di (a) Alun-alun, (b) Taman Kota, dan (c) Kompleks Olahraga Wiradadaha

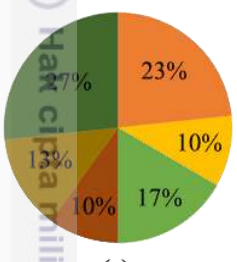

(a)

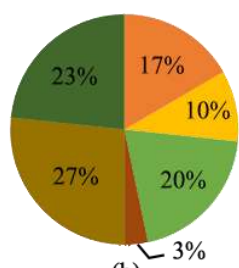

(b)

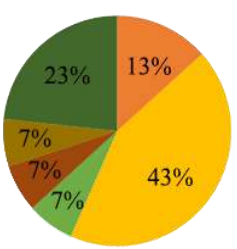

(c)

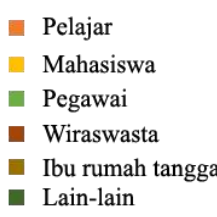

Lain-lain

Gambār 40 Persentase pekerjaan responden di (a) Alun-alun, (b) Taman Kota, dan (c) Kompleks Olahraga Wiradadaha

Sebesar 44\% responden di Alun-alun memiliki pendidikan terakhir perguruan tinggi. Kedua lokasi lain yaitu Taman Kota dan Kompleks Olahraga Wiradadaha didominasi oleh responden yang memiliki pendidikan akhir SMA dengan persentase yang sama yaitu 47\% (Gambar 41).

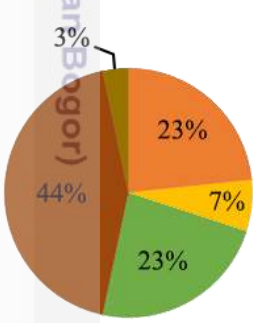

(a)

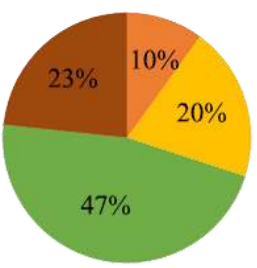

(b)

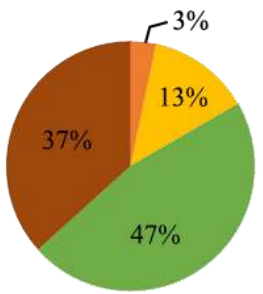

(c)

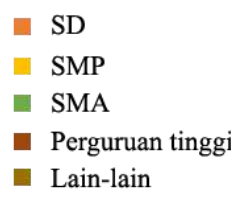

- Lain-lain

Gambar 41 Persentase pendidikan terakhir responden di (a) Alun-alun, (b) Taman Kota, dan (c) Kompleks Olahraga Wiradadaha

Responden yang datang ke Alun-alun dan Kompleks Olahraga Wiradadaha didominasi oleh responden dengan tujuan berolahraga sedangkan Taman Kota banyak dikunjungi oleh responden dengan tujuan rekreasi (Gambar 42). Responden Alun-alun memiliki tujuan yang lebih beragam dibandingkan dua lokasi lain. Tujuan lain-lain di Taman Kota memiliki persentase yang cukup tinggi, tujuan mereka antara lain untuk singgah sejenak, untuk bertemu seseorang, dan bekerja.

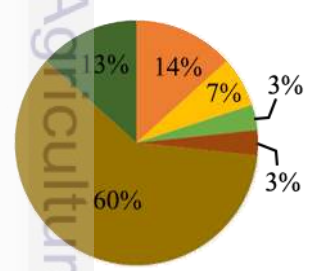

(a)

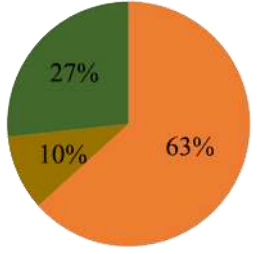

(b)

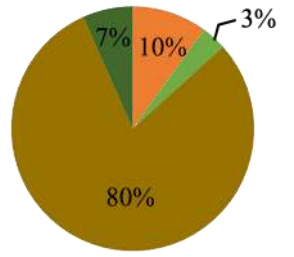

(c)

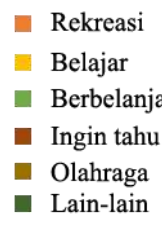

- Olahraga

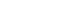

Gambar 42 Persentase tujuan kunjungan responden di (a) Alun-alun, (b) Taman Kota, dan (c) Kompleks Olahraga Wiradadaha 


\section{Persepsi responden}

Persepsi responden yang ingin diketahui dalam penelitian ini adalah persepsi mengenai kenyamanan, keindahan, kebersihan, dan kepuasan di masing-masing RTH. Persepsi responden menjadi contoh penilaian pengunjung secara umum terhadap masing-masing RTH. Persepsi responden diperlukan untuk melihat penilaian pengunjung yang secara langsung merasakan kondisi di $\mathrm{RTH}$, terutama kondisi iklim mikro. Menurut Brown dan Gillespie (1995), manusia merupakan instrumen yang sebenarnya dalam mengukur kenyamanan iklim mikro.

Persepsi responden mengenai kenyamanan RTH dilihat dari kesejukan, kelembaban, kecepatan angin, dan kebisingannya. Persepsi responden terhadap kelembaban, kecepatan angin, dan kebisingan sudah cukup sejalan dengan hasil penilaian dan pengukuran yang dilakukan namun persepsi responden terhadap kesejukan belum sejalan dengan hasil penilaian tanaman dan pengukuran suhu.

Berdasarkan penilaian tanaman dan pengukuran suhu, Taman Kota seharusnya sama sejuk dengan Alun-alun dalam persepsi responden namun mayoritas responden menilai Alun-alun sejuk dan Taman Kota sedang dalam kesejukannya. Hal tersebut terjadi karena tanaman berkategori baik di Taman Kota berkumpul di area yang tidak biasa responden kunjungi seperti area berumput.

Persepsi keindahan yang ditanyakan kepada responden mencakup keindahan pemandangan dan keindahan penataan tanaman. Keindahan pemandangan, keindahan penataan tanaman, dan kebersihan mempengaruhi penilaian pengunjung terhadap kualitas estetika lanskap. Sebagian besar responden menilai Alun-alun dan Taman Kota memiliki pemandangan yang indah dengan persentase masing-masing $50 \%$ dan $64 \%$ sementara sebagian besar responden Kompleks Olahraga Wiradadaha menilai pemandangan lanskap di sana sedang dengan persentase $67 \%$ (Gambar 43).

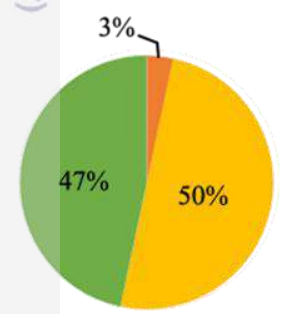

(a)

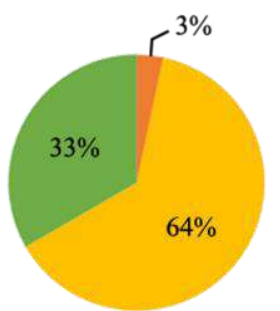

(b)

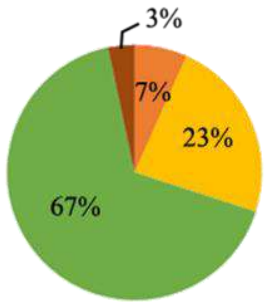

(c)

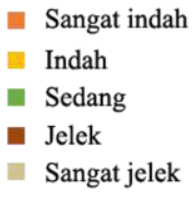

Gambar 43 Persepsi keindahan pemandangan oleh responden di (a) Alun-alun,

(b) Taman Kota, dan (c) Kompleks Olahraga Wiradadaha

Penilaian responden terhadap keindahan penataan tanaman pun tidak jauh berbeda dengan penilaian terhadap keindahan pemandangan. Alun-alun dan Taman Kota dinilai indah oleh masing-masing 57\% dan 60\% responden. Dalam penataan tanamannya, Kompleks Olahraga Wiradadaha yang dinilai sedang oleh $73 \%$ responden (Gambar 44).

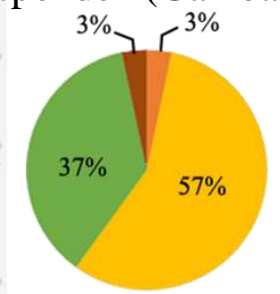

(a)

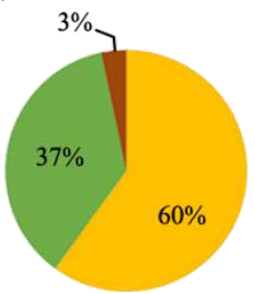

(b)

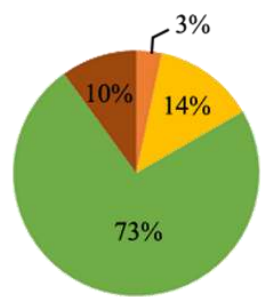

(c)

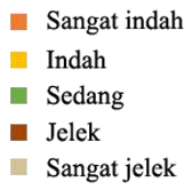

-10. Sangat jelek

Gambar 44 Persepsi keindahan penataan tanaman oleh responden di (a) Alunalun, (b) Taman Kota, dan (c) Kompleks Olahraga Wiradadaha 
Kebersihan RTH penting untuk diperhatikan karena dapat mempengaruhi kenyamanan dan keindahan RTH. Sebanyak 57\% dari total responden menilai Taman Kota bersih. Alun-alun dan Kompleks Olahraga Wiradadaha masih dinilai sedang oleh sebagian besar responden dengan masing-masing persentase $57 \%$ dan $60 \%$ dari total responden (Gambar 45).

Petugas kebersihan sebenarnya telah bekerja lebih baik dari tahun-tahun sebelumnya namun kesadaran pengunjung yang masih rendah membuat sampah masih berserakan di beberapa area. Kondisi yang berbeda dengan Alun-alun dan Taman Kota, Kompleks Olahraga Wiradadaha memiliki lokasi yang luas dan beberapa area memang dari awal kurang mendapat perawatan sehingga terlihat lebih kotor dan tidak indah.

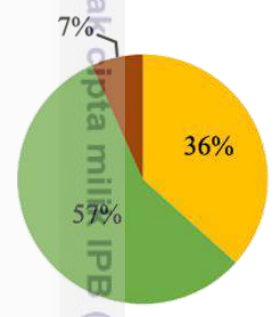

(a)

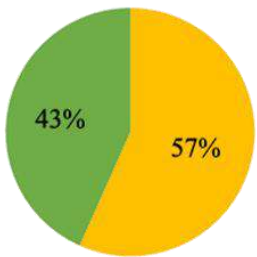

(b)

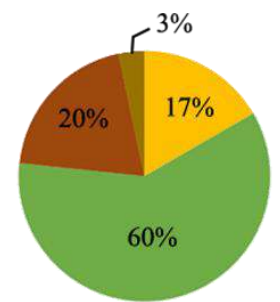

(c)
-1. Sangat bersih

Inersih

- Sedang

- Kotor

- Sangat kotor

Gambar 45 Persepsi kebersihan oleh responden di (a) Alun-alun, (b) Taman Kota, dan (c) Kompleks Olahraga Wiradadaha

Taman Kota menjadi RTH yang dinilai paling indah oleh sebagian besar responden. Hal itu tidak selaras dengan hasil penilaian SBE yang mengelompokan sebagian besar lanskap di Taman Kota pada kelompok estetika sedang namun bila dibandingkan berdasarkan kualitasnya, Taman Kota memang memiliki kualitas estetika lanskap yang paling baik dari ketiga RTH. Hal itu dilihat dari adanya lanskap di Taman Kota yang memiliki nilai SBE tertinggi dibandingkan lanskap di RTH lain. Lanskap Taman Kota juga memiliki rentang nilai SBE tertinggi-terendah yang pendek dibandingkan dengan RTH lain.

Berdasarkan persepsi kepuasannya, sebagian besar responden di Alun-alun dan Taman Kota sudah merasa puas dengan kondisi iklim mikro maupun keindahannya. Sebagian besar responden Kompleks Olahraga Wiradadaha merasa kepuasan pada tingkat sedang (Gambar 46). Responden sudah merasa terpenuhi kebutuhannya akan RTH sehingga sebagian besar responden sudah merasa puas dengan kondisi RTH yang ada.

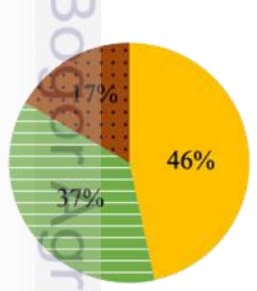

(a)

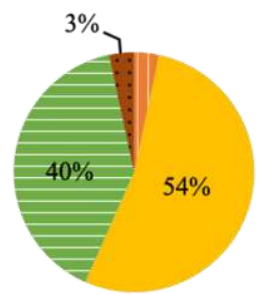

(b)

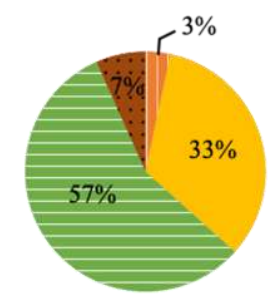

(c)

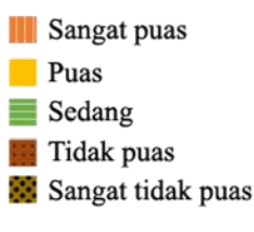

Gambar 46 Persepsi kepuasan terhadap (a) Alun-alun, (b) Taman Kota, dan (c) Kompleks Olahraga Wiradadaha 


\section{Preferensi responden}

Preferensi responden ditanyakan dalam bentuk pertanyaan terbuka. Pertanyaan terbuka dibuat agar responden dapat lebih bebas dalam memberi preferensinya mengenai RTH. Preferensi yang ditanyakan pertama kepada responden adalah aktivitas apa yang diinginkan ada di RTH. Sebagian besar responden Alun-alun merasa aktivitas olahraga sudah cukup. Beberapa lainnya menginginkan Alun-alun dapat dijadikan tempat berburu foto, pameran foto, dan piknik. Ada juga responden yang menginginkan diadakan kegiatan lingkungan seperti penanaman pohon, taman edukasi lingkungan, dan kegiatan lingkungan lain yang dapat meningkatkan kesadaran pengunjung akan lingkungan.

Responden Taman Kota sebagian besar menginginkan aktivitas untuk anakanak dengan lebih meningkatkan lagi fasilitas bermain anak. Beberapa responden menginginkan aktivitas olahraga seperti jogging, fitness, dan senam juga diadakan di Taman Kota. Aktivitas lain yang dinginkan responden antara lain berburu foto dan piknik.

Responden Kompleks Olahraga Wiradadaha memiliki keinginan yang cukup beragam tentang aktivitas yang ingin dilakukan, di antaranya senam (lansia dan aerobik), berdiskusi, berkumpul, kesenian, outbond, berkuda, dan menikmati pemandangan. Berdasarkan data karakteristik responden, Kompleks Olahraga Wiradadaha banyak dikunjungi oleh pelajar dan mahasiswa sehingga memberikan tempat berdiskusi yang nyaman dapat memberi stimulus baik untuk mereka. Selain sebagai tempat olahraga, Kompleks Olahraga Wiradadaha juga dibuat untuk memfasilitasi seniman dalam berkarya. Keinginan aktivitas kesenian yang dimaksud responden adalah dapat diadakannya kegiatan seni musik di dalam maupun luar ruangan, menonton teater, dan dibuatkannya tempat berkumpul bagi komunitas musik.

Saran dan harapan responden pun didapatkan melalui hasil wawancara dengan kuesioner pada ketiga RTH. Saran dan harapan yang paling banyak diberikan responden adalah pemberian tanaman berbunga yang dapat memberikan nilai estetika, penambahan tanaman peneduh untuk menambah kesejukan, peningkatan kesadaran pengunjung akan kebersihan, penambahan dan perbaikan fasilitas yang dibutuhkan pengunjung di RTH, peningkatan ketertiban, dan kontrol drainase di beberapa tempat.

\section{Rekomendasi Perbaikan Penataan Tanaman Ruang Terbuka Hijau}

\section{Alun-alun}

Alun-alun dinilai masih sedang dalam fungsi ekologis modifikasi suhu, penahan angin, dan peredam kebisingan. Penilaian tersebut namun dikuatkan oleh baiknya kontrol kelembaban di Alun-alun sehingga dapat memenuhi standar kenyamanan thermal. Kondisi Alun-alun yang memiliki potensi cukup banyaknya tanaman berkategori baik namun belum dimanfaatkan dan ditata dengan optimal. Rekomendasi perbaikan penataan tanaman di Alun-alun dispasialkan dalam Lampiran 8.

Tanaman berkategori baik dalam modifikasi suhu tersebar di sepanjang jalur jogging dan area berumput namun pengunjung lebih banyak berkumpul di area tugu yang memiliki bangku taman. Area tugu sering dijadikan tempat berkumpul 
meskipun area tersebut tidak teduh. Penambahan bangku taman dapat dilakukan di bawah tanaman berkategori baik di area jalur jogging sehingga tanaman berkategori baik dalam modifikasi suhu tersebut lebih fungsional (Gambar 47).

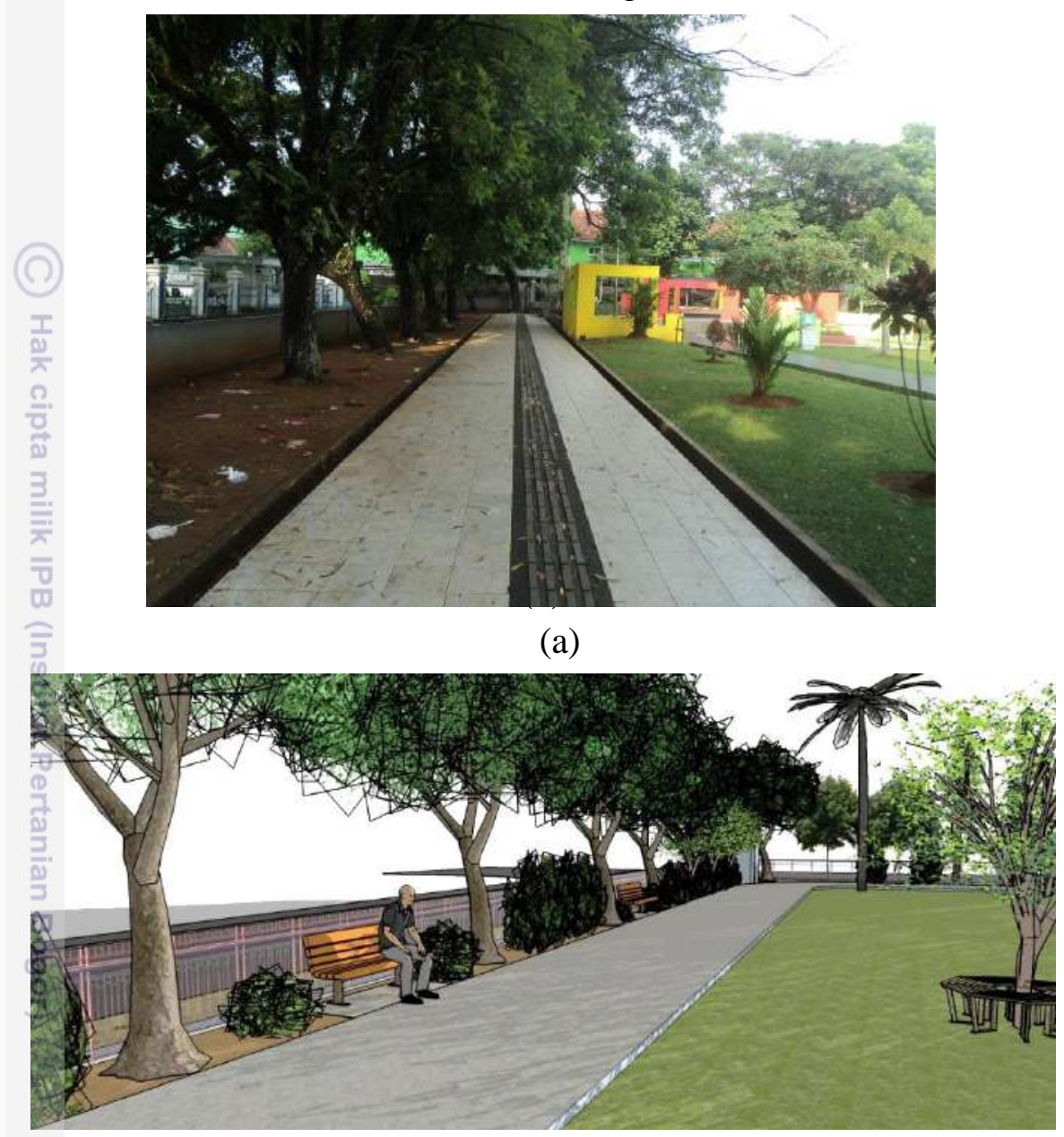

(b)

Gambar 47 Ilustrasi penambahan bangku taman di jalur jogging (a) sebelum dan (b) sesudah

Penambahan bangku taman di area jalur jogging juga didasari oleh kurangnya tempat duduk bagi pengunjung. Pengunjung lebih memilih duduk di jalur pedestrian yang memang teduh namun kurang nyaman untuk dilihat oleh pengunjung lain. Kondisi kelembaban Alun-alun dinilai sudah cukup baik. Kelembaban yang tinggi hanya ada di jalur tanaman sebelah Utara yang terlihat dari kondisi permukaan tanah yang lembab.

Kebisingan di Alun-alun masih belum mencapai baku mutu tingkat kebisingan RTH. Tanaman yang dikategorikan baik dalam meredam kebisingan pun masih kurang. Penanaman tanaman lain berupa pohon dan semak direkomendasikan untuk dilakukan di jalur tanaman lingkar luar Alun-alun (sepanjang jalur jogging) (Gambar 48). Penambahan semak dilakukan untuk meningkatkan peredaman kebisingan yang bersumber dari lalu lintas kendaraan. Menurut Cook et al (1983) dalam Slamet (2003), jalur tanaman yang tinggi dan rapat berkombinasi dengan semak akan mengurangi kebisingan sampai $50 \%$. 


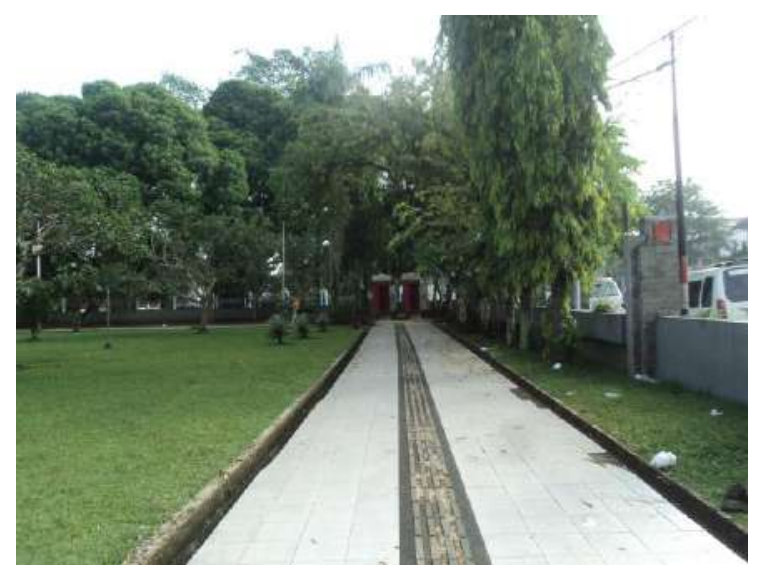

(a)

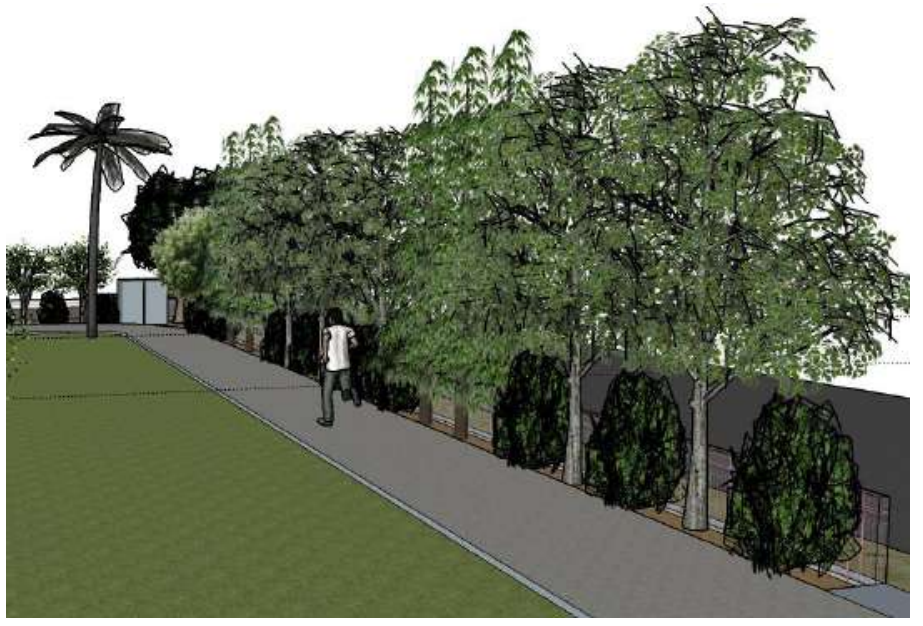

(b)

Gambar 48 Ilustrasi komposisi penataan tanaman peredam kebisingan (a) sebelum dan (b) sesudah

Kualitas lanskap Alun-alun masih didominasi oleh lanskap dengan nilai estetika sedang. Lanskap dengan nilai SBE tinggi terpusat di area tugu yang menerapkan prinsip kontras dengan tekstur dan pengulangan bentuk dari perkerasan dan tanaman penutup tanah (Gambar 49). Kualitas lanskap di area tugu akan lebih baik bila dilakukan penyulaman tanaman penutup tanah dilakukan.

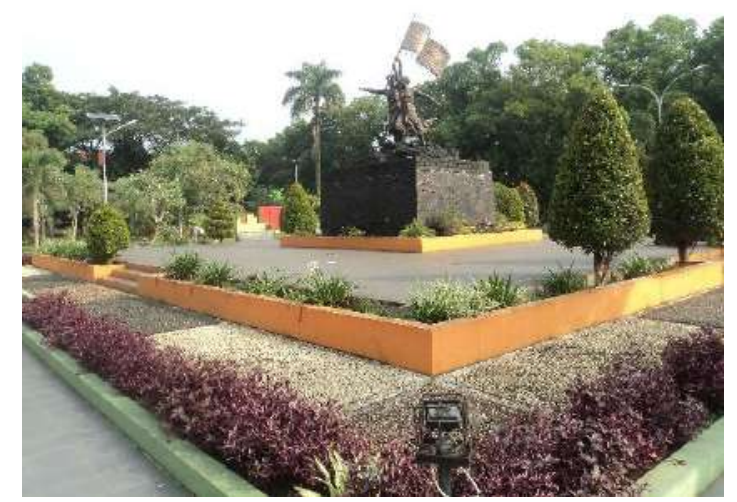

Gambar 49 Contoh penerapan prinsip desain variasi dan pengulangan dalam penataan tanaman 
Area lain seperti area gerbang dan area berumput masih dinilai sedang bahkan buruk dalam kualitas estetika lanskapnya. Penambahan tanaman berbunga dapat dilakukan untuk menambah keindahan. Penambahan tanaman perlu diperhatikan penataannya dengan memperhatikan prinsip desain seperti dilakukan dengan memperhatikan pengulangan, kontras, pola, dan keseimbangannya (Gambar 50).

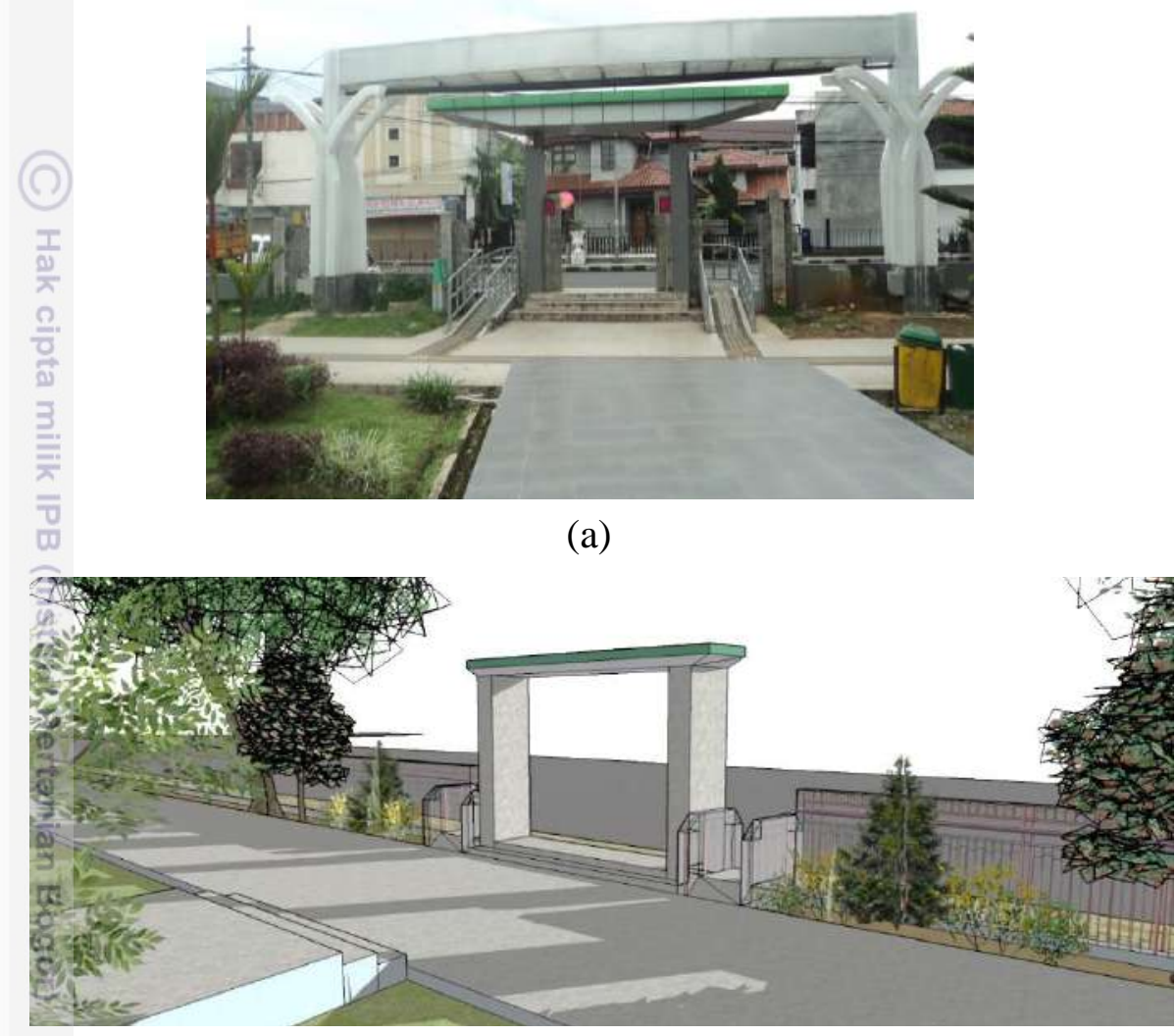

(b)

Gambar 50 Ilustrasi penataan tanaman di area gerbang (a) sebelum dan (b) sesudah

\section{Taman Kota}

Taman Kota memiliki paling sedikit jumlah tanaman di tapak. Sebagian besar tanaman telah di nilai baik dalam fungsi modifikasi suhu, kontrol kelembaban, dan penahan angin namun belum termasuk ke dalam kategori baik kecuali pada fungsi kontrol kelembaban. Baiknya Taman Kota dalam fungsi kontrol kelembaban mampu membuat Taman Kota masih termasuk ke dalam zona nyaman secara termal namun dengan perbaikan penataan tanaman, Taman Kota dapat lebih baik lagi dalam memberi kenyamanan thermal.

Meski tanaman berkategori baik dalam modifikasi suhu telah mendominasi, namun tanaman berkategori sedang dalam modifikasi suhu masih banyak tersebar di area parklet di mana pengunjung sering berkumpul. Penambahan tanaman peneduh yang baik dalam modifikasi suhu perlu dilakukan di planter box atau di sekitar area parklet tersebut agar planter box yang dijadikan tempat duduk oleh pengunjung dapat lebih terteduhi (Gambar 51). Tanaman yang dipilih sebagai peneduh disarankan memiliki ketinggian lebih dari $2 \mathrm{~m}$ dan bermassa daun rapat sehingga dapat lebih menyaring radiasi matahari. 


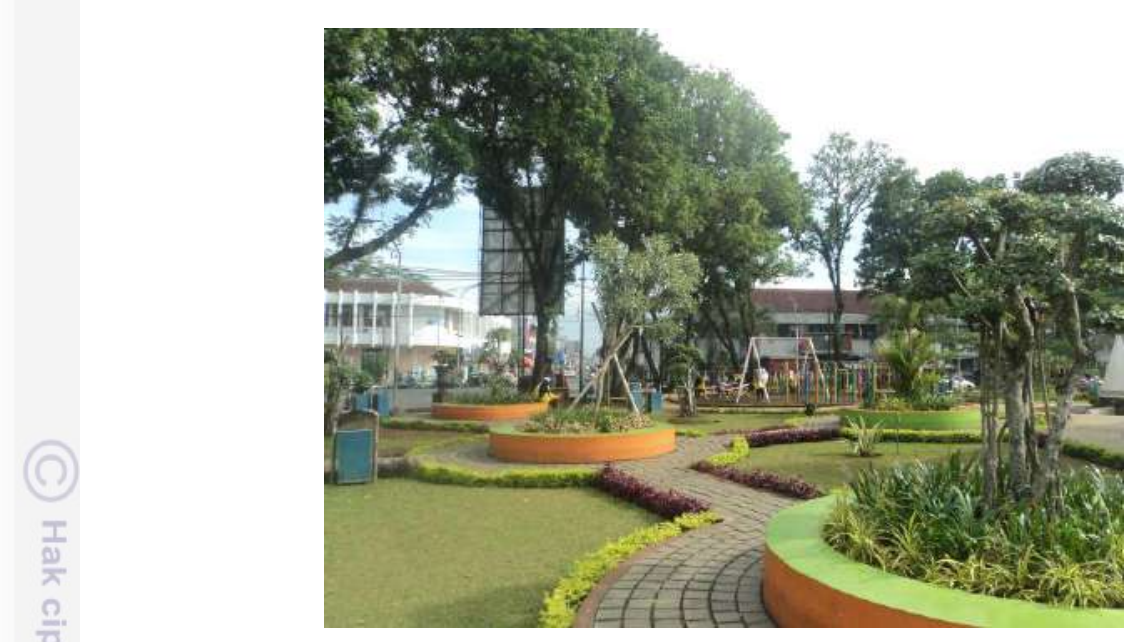

(a)

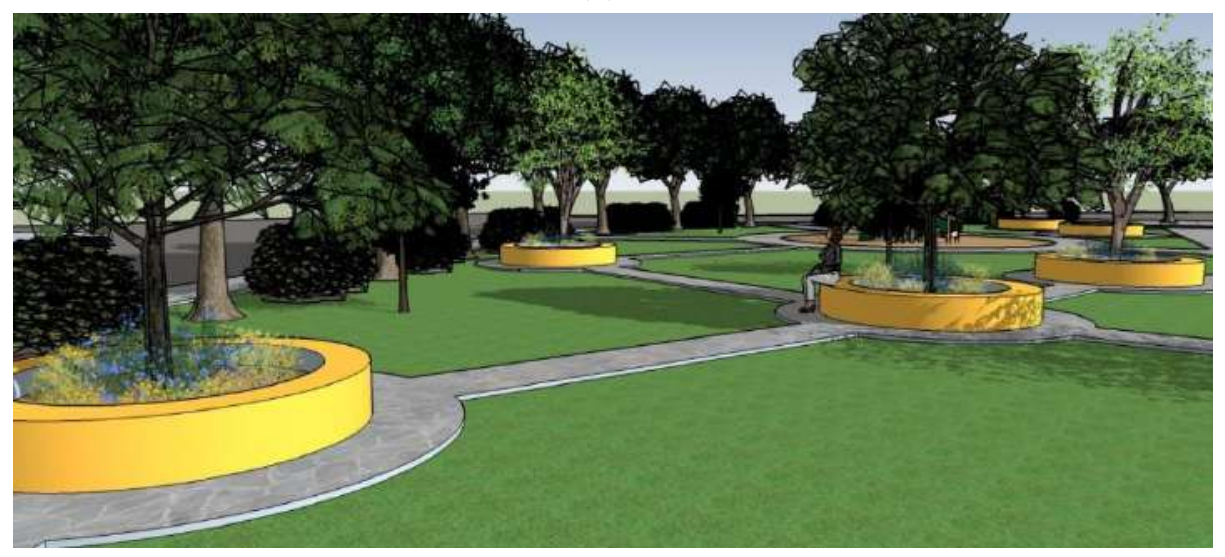

(b)

Gambar 51 Ilustrasi parklet setelah penambahan pohon peneduh (a) sebelum dan (b) sesudah

Sebagian besar tanaman dinilai sedang pada fungsi peredam kebisingan. Taman Kota memiliki kebisingan paling tinggi dibandingkan RTH lain. Lalu-lintas kendaraan di sekitar Taman Kota yang selalu sibuk mempengaruhi hal tersebut. Batas-batas antar dalam tapak dengan luar tapak perlu lebih ditambahkan lagi tanaman dengan variasi ketinggian yang berbeda, seperti pohon dengan semak, untuk lebih meredam kebisingan yang datang dari luar tapak (Gambar 52).

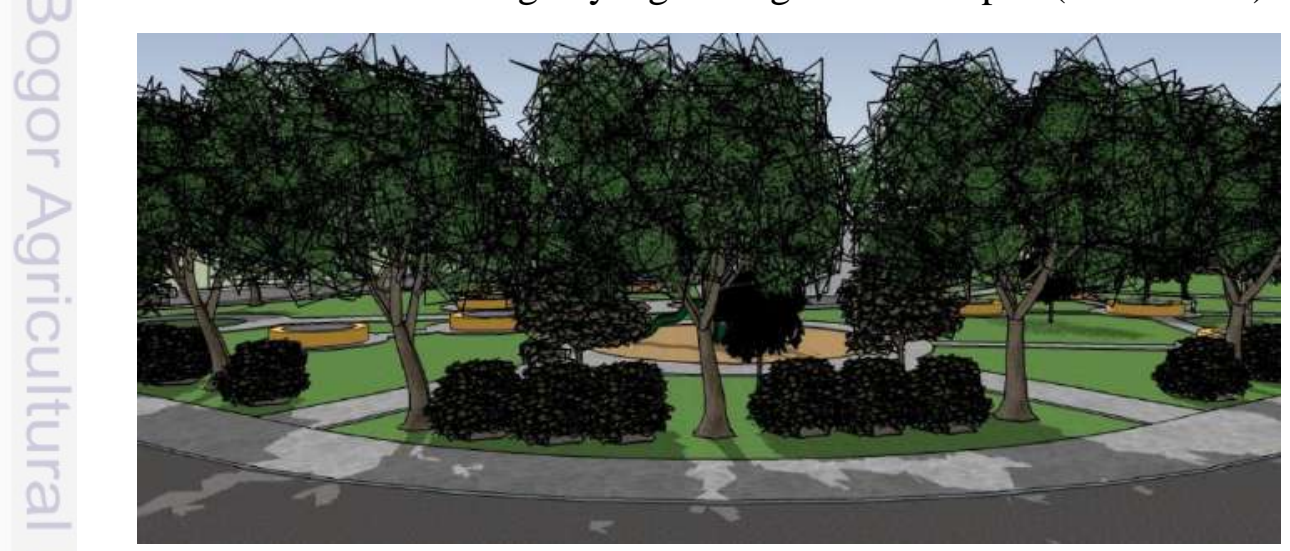

Gambar 52 Ilustrasi komposisi tanaman untuk meredam kebisingan 
Lanskap Taman Kota masih didominasi oleh lanskap estetika sedang. Peningkatan kualitas estetika lanskap dapat dilakukan dengan penambahan variasi tanaman terutama tanaman berbunga. Penambahan tanaman dapat dilakukan di lanskap yang masih dinilai sedang hingga rendah estetikanya.

Secara keseluruhan, penataan tanaman di Taman Kota dinilai cukup indah namun area berumput di sebelah Selatan perlu penataan tanaman yang lebih baik agar dapat meningkatkan nilai estetika dan fungsi. Area berumput hanya menampilkan jejeran pohon, palem, dan tanaman penutup tanah. Berdasarkan hasil wawancara dengan pengelola, area tersebut direncanakan akan dibuat sebagai lokasi air mancur. Penataan yang sebaiknya dilakukan adalah memusatkan air mancur tersebut di tengah area sebagai focal point. Tanaman yang ada saat ini dapat disusun secara berulang di sekeliling atau sudut-sudut area (Gambar 53).

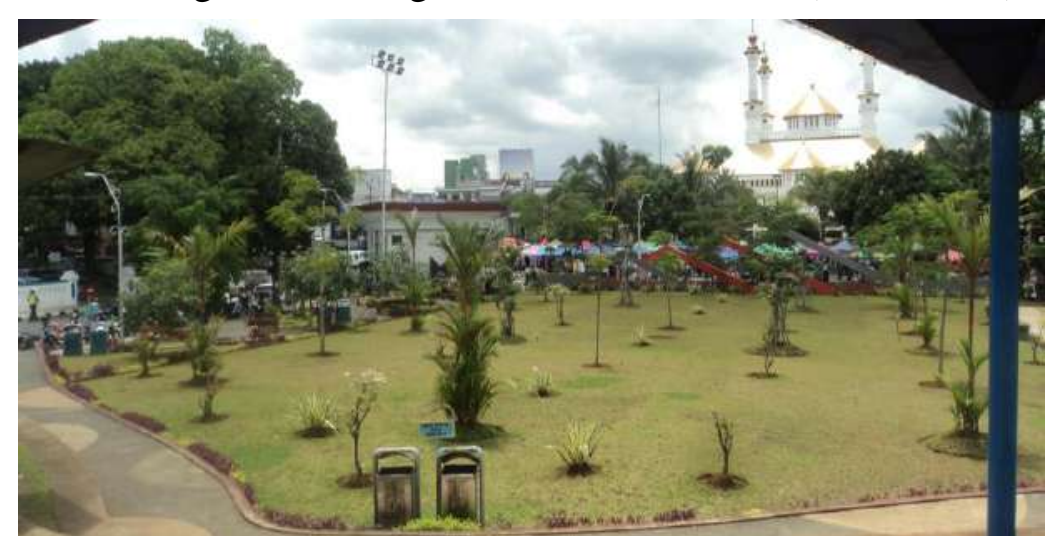

(a)

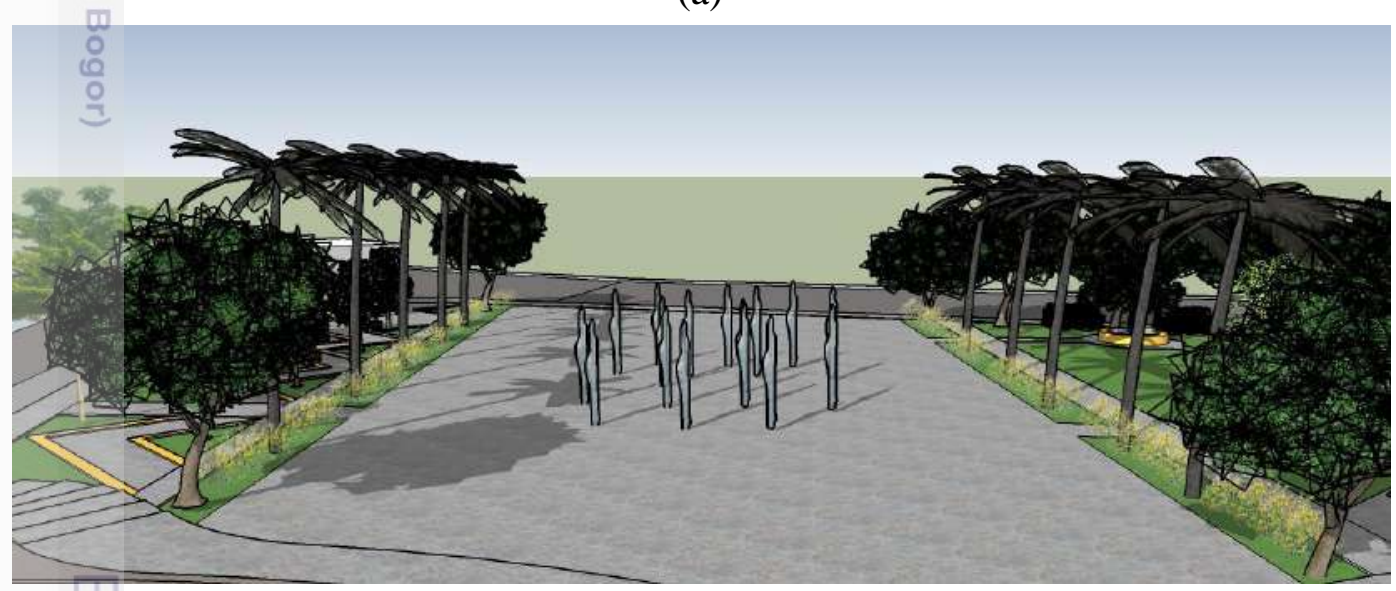

(b)

\section{Kompleks Olahraga Wiradadaha}

Kompleks Olahraga Wiradadaha telah memiliki penataan tanaman yang cukup baik terutama dalam fungsi ekologis. Hal yang dapat dilakukan untuk menjaga standar kenyamanan thermal adalah melakukan pengelolaan tanaman dengan teratur. Kebisingan di Kompleks Olahraga Wiradadaha sudah cukup rendah, namun masih dapat diturunkan dengan penambahan tanaman dan penataan tanaman yang lebih baik. Area lapangan terbuka menjadi area yang masih bising. 
Penurunan kebisingan dapat disiasati dengan penambahan tanaman penutup tanah di planter box yang berada di sekeliling area lapangan terbuka.

Kualitas estetika lanskap Kompleks Olahraga Wiradadaha menjadi yang paling rendah dibandingkan RTH lain lebih disebabkan karena buruknya kondisi elemen keras dan kebersihan. Tanaman secara alami memberikan nilai estetika dengan bentuk, warna, bahkan aroma dari tajuk, batang, daun, dan bunga yang dimilikinya (Lestari, Yanuwiadi, Soemarno 2013). Lestari dan Gunawan (2010) pun menyatakan bentuk tajuk horizontal, bayangan pohon, serta warna bunga dan daun menjadi unsur yang menarik dari pohon. Pepohonan di Kompleks Olahraga Wiradadaha memberi nilai estetika tersendiri dengan bentuk tajuk dan dedaunan yang hijau (Gambar 54).

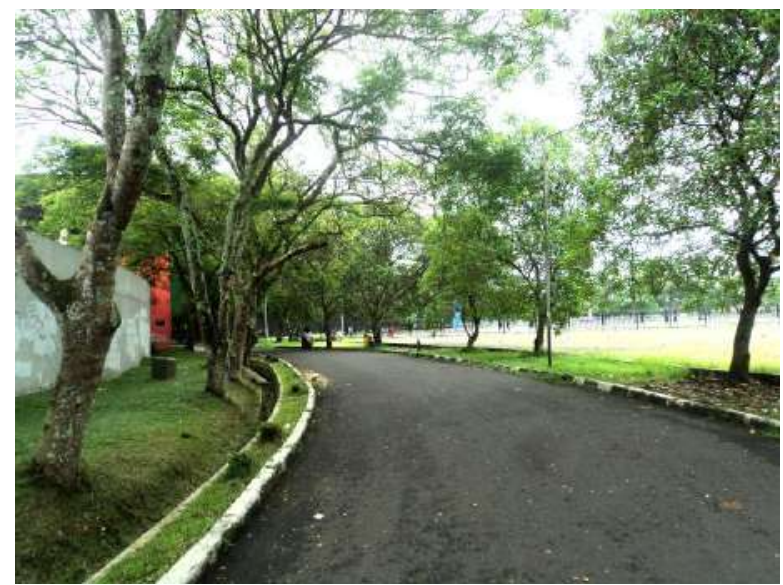

Gambar 54 Contoh pepohonan dengan bantuk tajuk

Penanaman pepohonan dengan pola linear di beberapa area sudah cukup baik karena menerapkan prinsip desain pengulangan (Gambar 55). Penanaman pepohonan dengan pola kelompok yang rapat di beberapa area terkesan suram karena rapatnya tajuk membuat kurang adanya cahaya yang masuk dapat memberikan nilai estetika yang rendah (Hidayat 2009). Penjarangan tajuk dan pembersihan serasah dapat meningkatkan kesehatan dan estetika lanskap RTH (Chen, Sun, Liao, Chen, Luo 2016). Penjarangan juga dapat dilakukan pada tanaman rambat, Bougenville sp., agar dari bawah pergola dapat lebih memperlihatkan bunganya yang bermekaran daripada batang rambat yang telah mati.

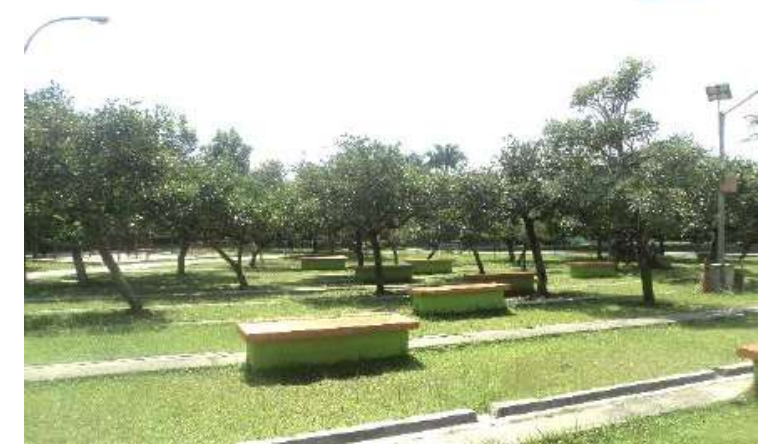

Gambar 55 Contoh penerapan prinsip desain pengulangan

Tanaman terkesan monoton karena kurangnya keragaman horizontal dan vertikal tanaman di beberapa area. Penambahan tanaman terutama tanaman estetika 
dapat dilakukan sehingga dapat menambah variasi dari tanaman. Penambahan tanaman estetika dapat ditambahkan di area bermain anak, taman terapi, hutan kota, dan area kebugaran yang dinilai masih rendah kualitas estetika lanskapnya (Lampiran 10).

\section{SIMPULAN DAN SARAN}

\section{Simpulan}

Tanaman di setiap RTH memiliki kondisi yang beragam. Pohon di Alun-alun terdiri dari 18 spesies dengan 207 total individu. Pohon di Taman Kota terdiri dari 8 spesies dengan 90 total individu. Pohon di Kompleks Olahraga Wiradadaha terdiri dari 36 spesies dengan 870 total individu. Hasil penilaian berdasarkan fungsi ekologis menunjukkan Kompleks Olahraga Wiradadaha merupakan RTH terbaik dalam āspek fungsi modifikasi suhu, kontrol kelembaban, dan peredam kebisingan sedangkan Taman Kota terbaik dalam fungsi penahan angin.

Alun-alun, Taman Kota, dan Kompleks Olahraga Wiradadaha telah memenuhi standar kenyaman thermal dan memenuhi standar baku mutu kebisingan kawasan rekreasi. Berdasarkan penilaian tanaman, Kompleks Olahraga Wiradadaha merupakan terbaik dalam fungsi modifikasi suhu, kontrol kelembaban, dan peredam kebisingan dibandingkan dengan dua RTH lainnya. Taman Kota merupakan terbaik dalam fungsi penahan angin dibandingkan dua RTH lainnya. Secara keseluruhan, ketiga RTH rata-rata mampu menurunkan suhu sebesar $1.4^{\circ} \mathrm{C}$ dan meningkatkan kelembaban $8 \%$. Ketiga RTH juga rata-rata dapat menurunkan kebisingan sebesar $4.4 \mathrm{~dB}$. Hasil evaluasi kualitas estetika lanskap menunjukkan lanskap Taman Kota merupakan RTH dengan kualitas estetika lanskap terbaik dibandingkan dengan lanskap di Alun-alun dan Kompleks Olahraga Wiradadaha. Kompleks Olahraga Wiradadaha merupakan RTH dengan kualitas estetika lanskap terendah.

Masyarakat merasa cukup puas dengan kondisi ketiga RTH namun masyarakat menginginkan penambahan tanaman peneduh khususnya di Alun-alun dan Taman Kota, penambahan tanaman estetika, penambahan dan perbaikan fasilitas seperti perkerasan, bangku, kolam, serta alat bermain dan olahraga. Rekomendasi dibuat untuk masing-masing RTH berdasarkan hasil evaluasi fungsi ekologis, estetika, dan persepsi preferensi responden. Alun-alun dan Taman Kota perlu penambahan tanaman peneduh. Ketiga RTH perlu penambahan tanaman estetika untuk meningkatkan kualitas estetika lanskap serta pengaturan komposisi dalam peletakan tanaman agar tanaman lebih fungsional.

\section{Saran}

Penelitian selanjutnya dapat dikembangkan dan dispesifikan pada desain penanaman lanskap dan pemilihan tanaman sehingga akan diperoleh fungsi RTH yang lebih optimal. Pengelola dapat memperbaiki dan menambahkan fasilitas yang dibutuhkan pengunjung. Pengelola juga dapat mengoptimalkan fungsi dari areaarea yang telah ada terutama di Kompleks Olahraga Wiradadaha seperti lapangan kosong, tempat bermain anak, dan gedung kesenian. 


\section{DAFTAR PUSTAKA}

Abello RP, Bernaldez FG. 1986. Landscape preference amd personality. Landscape and Urban Planning. 13: 19-28.

Abreu-Habrich LV, Lucila CL, dan Andreas M. 2015. Effect of tree planting design and tree species on human thermal comfort in the tropics. Landscape and Urban Planning. 138: 99-109.

Barrera F et al. 2016. People's perception influences on the use of green spaces in socio-economically differentiated neighborhoods. Urban Forestry \& Urban Greening. 20: 254-264.

Bianpoen et al. 1989. Fungsi Taman dalam Kota (naskah laporan). Jakarta (ID):

Pusat Penelitian Teknologi dan Pemukiman Universitas Tarumanegara.

BPS Kota Tasikmalya. 2016. Tasikmalaya dalam Angka: Tasikmalaya Manucipality in Figures. Tasikmalaya (ID): BPS Kota Tasikmalaya.

. 2017. Statistik Daerah Kota Tasikmalaya. Tasikmalaya (ID): BPS Kota Tasikmalaya.

Brown RD dan Terry JG. 1995. Microclimatic Landscape Design: Creating Thermal Comfort and Energy Efficient. USA: John Wiley \& Sons, Inc.

Brown RD, Jennifer V, Natasha K, Sanda L. 2015. Designing urban park that ameliorate the effects of climate change. Landscape and Urban Planning. 138: 118-131.

Carpenter PL, TD. Walker dan FO. Lamphear. 1975. Plants in The Landscape. San Fransisco (US): W.H Freeman and Co.

Chen Y, B. Sun, S.B. Liao, L. Chen, S.X. Luo. 2016. Landscape perception based on personal attributes in determining the scenic beauty of in-stand natural 3 secondary forest. Ann.For.Res. 59 (1): 91-103.

Daniel TC dan Boster RS. 1976. Measuring Landscape Aesthetics: the Scenic Beauty Estimation Method. USDA Forest Service Research Paper. RM- 167.

Departemen Kesehatan. 1999. Keputusan Menteri Kesehatan Nomor 829/Menkes/SK/VII/1999. Jakarta (ID): Departemen Kesehatan.

Departemen Pekerjaan Umum. 1996. Tata Cara Perencanaan Teknik Lanskap Jalan. Direktorat Jenderal Bina Marga. Jakarta (ID): Departemen Pekerjaan Umum. . 2007. Undang - Undang Indonesia Nomor 26 Tahun 2007 tentang Penataan

Ruang. Jakarta (ID): Direktorat Jenderal Penataan Ruang. . 2008. Peraturan Menteri Pekerjaan Umum Nomor:05/PRT/M/2008 tentang Pedoman Penyediaan dan Pemanfaatan Ruang Terbuka HIjau di Kawasan Perkotaan. Jakarta (ID): Direktorat Jenderal Penataan Ruang. . 2012. Peraturan Menteri Pekerjaan Umum Nomor: 05/PRT/M/2012 tentang Pedomen Penanaman Pohon pada Sistem Jaringan Jalan. Jakarta (ID): Direktorat Jenderal Penataan Ruang.

Eckbo G. 1964. Urban Landscape Design. New York (US): Mc.Graw-Hill Book Co. 248p.

Effendi S, A Bey, AFM. Zain, I Santosa. 2006. Peranan ruang terbuka hijau dalam mengendalikan suhu udara dan urban heat island wilayah Jabotabek. Agromet Indonesia. 20 (01): 23-33. 
Emmanuel R. 2005. Thermal comfort implication of urbanization in a warm humid city : the Colombo Metropolitan Region (CMR). Build and Environ. 40 : 15911601.

Fathy H. 1986. Natural Energy and Ver-nacular Architecture. Chicago (US): The Univer-sity of Chicago Press.

Femy. 2014. Perencanaan tata hijau untuk kenyamanan klimatologis pada Balai Besar Pengembangan Mekanisasi Pertanian [tesis]. Bogor (ID): Sekolah Pasca Sarjana Institut Pertanian Bogor.

Grey GW, FJ Daneke. 1978. Urban Forestry. New York (US): John Willey and Sons inc.

Handoko. 1995. Klimatologi Dasar. Jakarta (ID): Pustaka Jaya.

Hansen G. 2016. Basic principles of landscape design. Florida (USA): Environmental Horticulture Department, UF/IFAS Extension.

Hidayat I. 2008. Evaluasi jalur hijau jalan sebagai penyangga lingkungan sekitarnya dan keselamatan pengguna jalan bebas hambatan Jagorawi [tesis]. Bogor (ID): Institut Pertanian Bogor.

Hidayat IW. 2009. Uji scenic beauty estimation terhadap konfigurasi tegakan-tegakan tanaman di Kebun Raya Bogor. Prosiding SN SMAP. 09.

Kaplan S. 1988. Perception and Landscape: Conception and Misconceptions. In Jack LN. Editor. Enviromental Aesthetics. New York (US): Cambridge Univ. Pr. p 44-45.

Laurie M. 1986. An Introduction to Landscape Architecture. New York (US): American Elsevier Publ. Co. Inc.

Lestari G, Andi G. 2010. Pengaruh bentuk kanopi pohon terhadap kualitas estetika lanskap jalan. Lanskap Indonesia. 2:1.

Lestari I, Bagyo Y, Soemarno. 2013. Analisis kesesuaian vegetasi lokal untuk ruang terbuka hijau jalur jalan di pusat Kota Kupang. Pembangunan Alam Lestari. 4:1.

Mahardi F. 2013. Evaluasi fungsi ekologis dan estetika pada beberapa taman kota di Jakarta [skripsi]. Bogor (ID): Institut Pertanian Bogor.

Mariski, Nizar N, Andi G. 2017. Persepsi dan preferensi pengunjung terhadap kenyamanan klimatologis di Taman Menteng dan Taman Honda Tebet. Lanskap Indonesia. 9:1.

Mulyana E. 2017. Inilah perkembangan data kependudukan Kota Tasikmalaya. [internet]. [Diunduh pada: 2017 Oktober 17]. Terdapat pada: https://www.cakrawalamedia.co.id/inilah-perkembangan-data-kependudukankota-tasikmalaya/.

Mulyana M, Laras T, Budi SH. 2003. Impact of urban Development on the Climate and Environment. Bandung (ID): ITB Press.

Nassar JL. 1988. Environmental Aesthetic. New York (US): Cambridge Univ Pr. 529 p.

Nurnovita C. 2011. Evaluasi fungsi ekologis pohon pada RTH lanskap permukiman Sentul City, Bogor (Studi Kasus: Cluster Bukit Golf Hijau) [skripsi]. Bogor (ID): Institut Pertanian Bogor.

Pemerintah Kota Tasikmalaya. 2008. Peraturan Daerah Kota Tasikmalaya Nomor 9 Tahun 2008 tentang Rencana Pembangunan Jangka Panjang (RPJP) Kota Tasikmalaya Tahun 2005-2025. Tasikmalaya (ID): Bappeda Kota Tasikmalaya. 
Pratama GE. 2013. Rencana pengembangan ruang terbuka hijau berdasarkan distribusi suhu permukaan dan temperature humidity index (THI) di Kota Surakarta [skripsi]. Bogor (ID): Institut Pertanian Bogor.

Saputro TH, Indung SF, dan Bambang S. 2010. Studi pengaruh area perkerasan terhadap perubahan suhu udara (Studi kasus Area Parkir Plaza Senayan, Sarinah Thamrin, dan Stasiun Gambair). Lanskap Indonesia. 2: 2.

Simonds JO. 1983. Landscape Architecture. New York (US): Mc Graw - Hill Book Co.

Slamet L. 2003. Ruang terbuka hijau di Jakarta. Perencanaan Pembangunan. 31.

Sukewijaya IM, Naniek K. 2015. Studi karakteristik tanaman gumi banten untuk I lanskap pohon tepi jalan. Bumi Lestari. 15:2.

Tim Pelaksana Satuan Kerja Sanitasi Kota Tasikmalaya. 2012. Buku Putih Sanitasi Kota Tasikmalaya Tahun 2012. Tasikmalaya (ID): Tim Pelaksana Kelompok Kerja PPSP Kota Tasikmalaya.

Uma H. 2015. Persepsi: pengertian, definisi, dan faktor yang mempengaruhi. Kompasiana. [Internet]. (2015 Jun 24 [diunduh 2017 Okt 20]). Tersedia pada:https://www.kompasiana.com/hasminee/persepsi-pengertian-definisi-dan= factor-yang-mempengaruhi_552999136ea8349a1f552d01.

Whiting D, De JJ. 2012. Ater ise Landscape Design: Principles of Landscape Design. Colorado (US): Colorado State University Extension.

Yan H, Li D. 2015. The impacts of landcover types on urban outdoor thermal environment. Environmental Health Science and Engineering. 13: 43.

Zahra AF, Sitawati, A. Suryanto. 2014. Evaluasi keindahan dan kenyamanan RTH Alun-alun Kota Batu. Produksi Tanaman. 2 (7): 524-532. 
Lampiran 1 Contoh penilaian fungsi ekologis tanaman

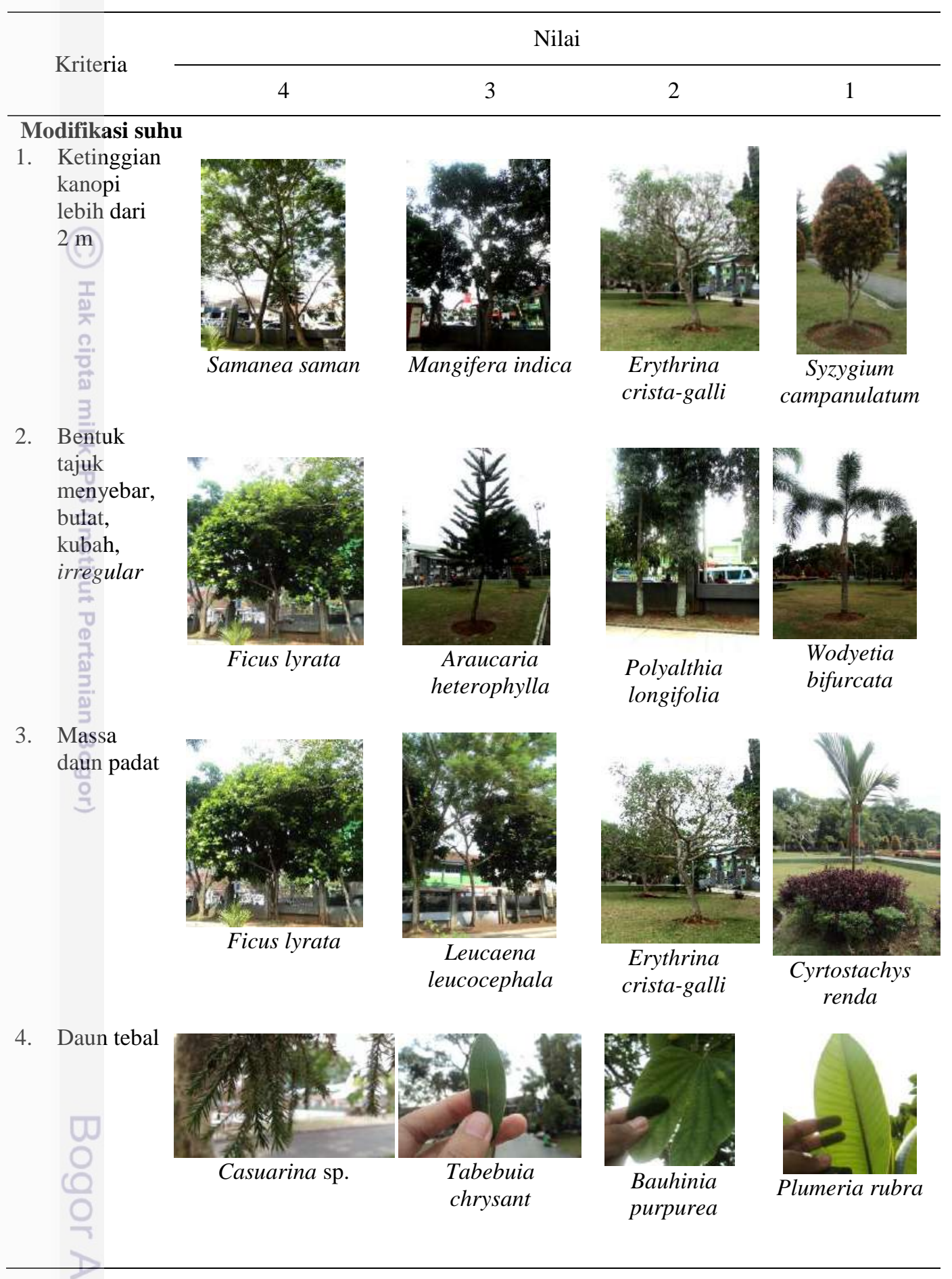


Lampiran 1 Contoh penilaian fungsi ekologis tanaman (lanjutan)

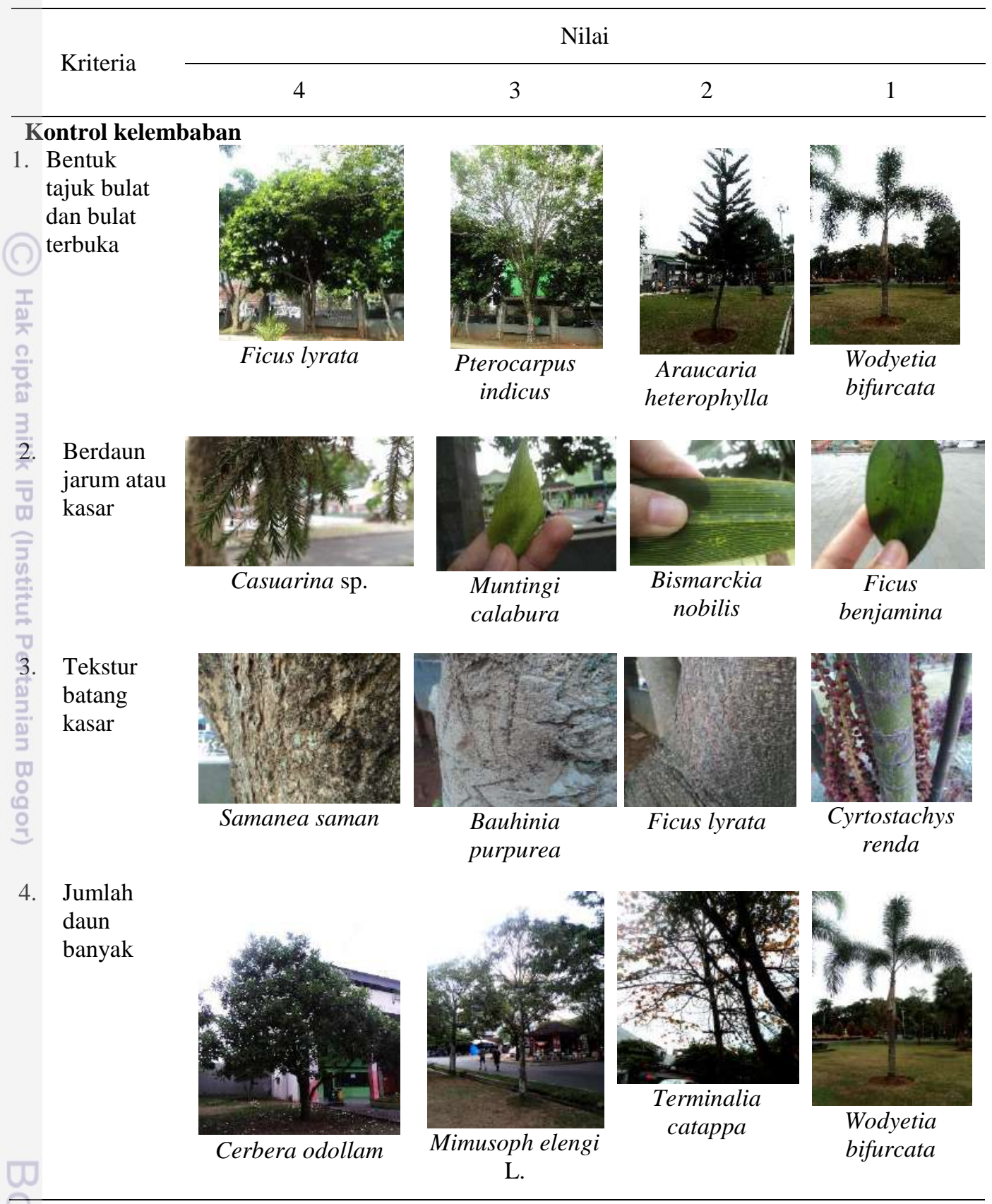


Lampiran 1 Contoh penilaian fungsi ekologis tanaman (lanjutan)

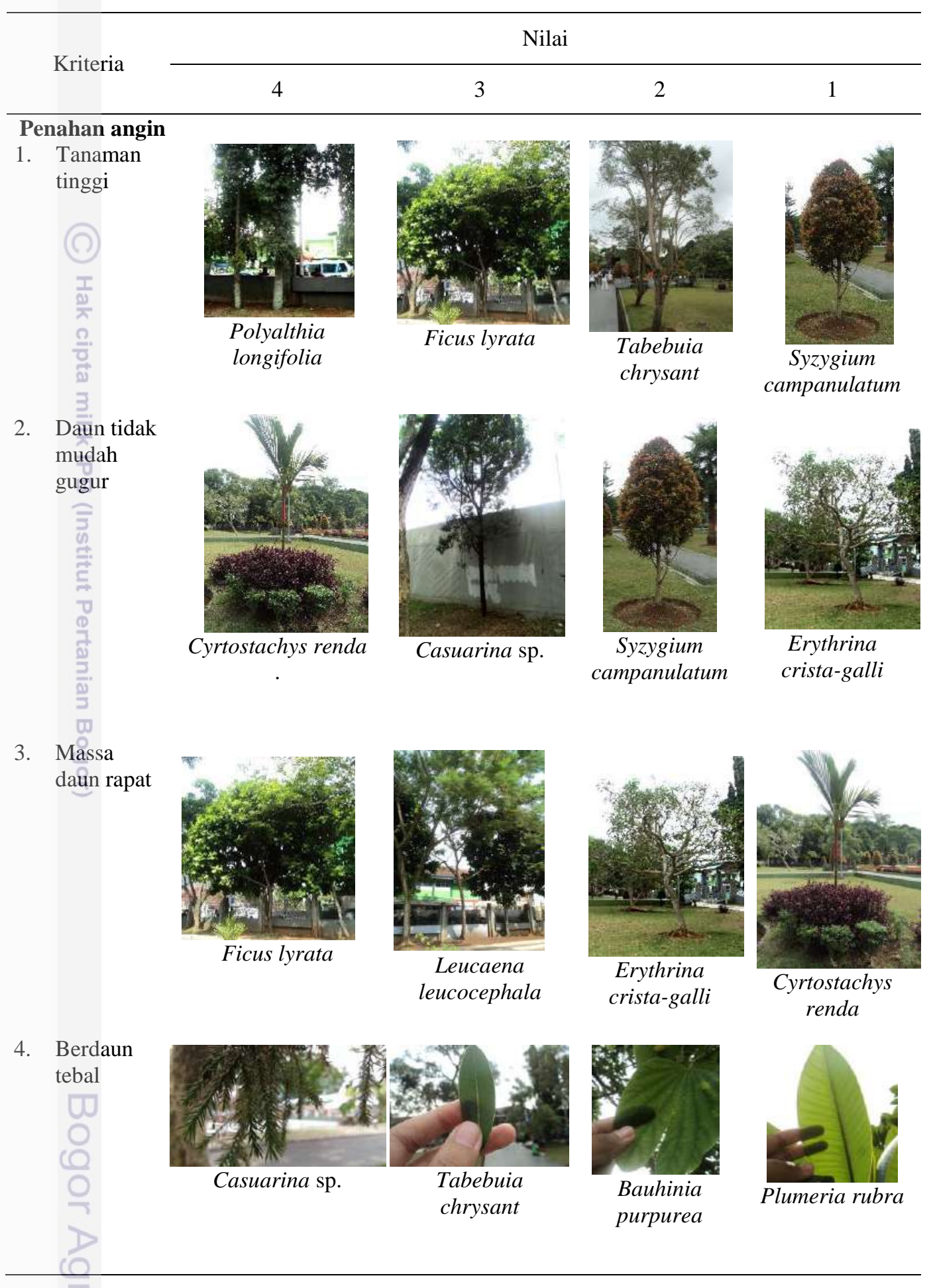


Lampiran 1 Contoh penilaian fungsi ekologis tanaman (lanjutan)

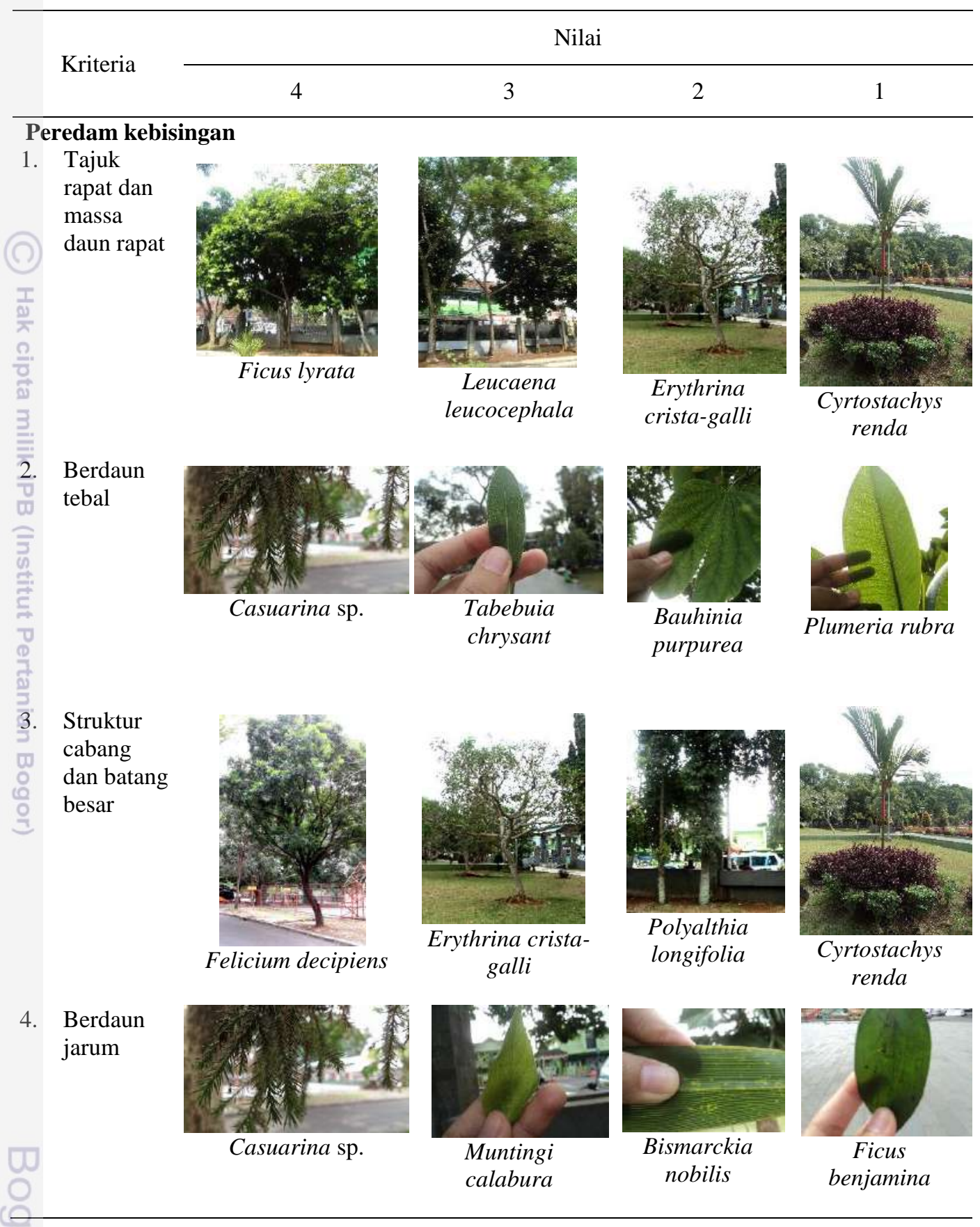


Lampiran 2 Kuesioner pengunjung Alun-alun

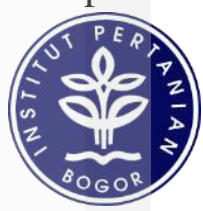

DEPARTEMEN ARSITEKTUR LANSKAP

FAKULTAS PERTANIAN INSTITU PERTANIAN BOGOR

Kuesioner Penelitian

KAJIAN FUNGSI EKOLOGIS DAN ESTETIKA BEBERAPA RUANG TERBUKA

HIJAU DI KOTA TASIKMALAYA

Tanggal Pengambilan :

No. Kuesioner

Assalamualaikum Wr. Wb.

Saya Intan Nur Fathonah, mahasiswa semester 8 Departemen Arsitektur Lanskap, Institut

Pertanian Bogor. Saya mengharapkan bantuan dari Bapak/Ibu/Saudara untuk mengisi

kuesioner penelitian saya yang berjudul Kajian Fungsi Ekologis dan Estetika Beberapa

Ruang Terbuka Hijau di Kota Tasikmalaya. Terima kasih atas kesediaannya.

A. Karakteristik Responden
E. Nama
2. Umur
3. Jenis Kelamin
4. Daerah Asal
5. Pendidikan terakhir Anda:
a. SD
b. SMP
c. SMA
d. Perguruan tinggi
e. Lainnya

6. Pekerjaan/Profesi Anda saat ini:
a. Pelajar
b. Mahasiswa
c. Pegawai (Negeri/Swasta)
d. Perguruan tinggi
e. Lainnya

B. Preferensi Responden

7. Tujuan Anda mengunjungi RTH:
a. Rekreasi
b. Belajar
e. Olahraga
c. Berbelanja
d. Ingin tahu
f. Lainnya

8. Kunjungan Anda untuk:
b. Kedua kali
a. Pertama kali
c. Ketiga kali
d. Lebih dari tiga kali

9. Lama kunjungan Anda di RTH:
a. <30 menit
b. $30-60$ menit
c. 1-2 jam
d. $>2$ jam

10. Frekuensi kunjungan Anda:
a. Setiap hari
b. Setiap minggu
c. Setiap bulan
d. Tidak tentu
e. Lainnya

11. Jarak RTH dari tempat tinggal anda:
a. $<500 \mathrm{~m}$
b. $500 \mathrm{~m}-1 \mathrm{~km}$
c. $>1 \mathrm{~km}$
d. $1-3 \mathrm{~km}$
e. $>3 \mathrm{~km}$

12. Aktivitas yang dilakukan di RTH:
a. Berkumpul dengan teman/keluarga
b. Duduk-duduk dan menikmati pemandangan
c. Berjalan-jalan 

d. Berfoto
e. Berolahraga
f. Lainnya ....

\section{Presepsi Responden}

13. Kesan Anda tentang pemandangan RTH:
a. Sangat indah
b. Indah
d. Jelek
e. Sangat jelek
c. Sedang

Lokasi mana saja yang menurut Anda indah?
a. Tugu
b. Gerbang
d. Jogging track
e. Lapangan rumput
c. Tempat bermain skateboard
f. Lainnya.

14. Kesan Anda tentang penataan tanaman RTH:
a. Sangat indah
b. Indah
d. Jelek
e. Sangat jelek
c. Sedang

Lokasi mana saja yang menurut Anda indah?
a. Tugu
b. Gerbang
d. Jogging track
e. Lapangan rumput
c. Tempat bermain skateboard
f. Lainnya....

15. Kesan Anda tentang kenyamanan suhu di RTH:
a. Sangat sejuk
b. Sejuk
d. Panas
e. Sangat panas
c. Sedang

Lokasi mana saja yang menurut Anda sejuk?
a. Tugu
b. Gerbang
d. Jogging track
e. Lapangan rumput
c. Tempat bermain skateboard
f. Lainnya....

16. Kesan Anda tentang kebisingan RTH:
a. Sangat tenang
b. Tenang
d. Bising
e. Sangat bising
c. Sedang

Lokasi mana saja yang menurut Anda tenang?
a. Tugu
b. Gerbang
d. Jogging track
e. Lapangan rumput
c. Tempat bermain skateboard
f. Lainnya....

17. Kesan Anda tentang hembusan angin pada RTH:
a. Sangat pelan
b. Pelan
d. Kencang
e. Sangat kencang
c. Sedang

Lokasi mana saja yang menurut Anda pelan?
a. Tugu
b. Gerbang
d. Jogging track
f. Lapangan rumput
c. Tempat bermain skateboard
g. Lainnya.

18. Kesan Anda tentang kelembaban udara RTH:
a. Sangat kering
b. Kering
d. Lembab
e. Sangat lembab
c. Sedang

Lokasi mana saja yang menurut Anda lembab?
a. Tugu
b. Gerbang
d. Jogging track
e. Lapangan rumput
c. Tempat bermain skateboard
f. Lainnya...

19. Kesan Anda tentang kebersihan RTH:
a. Sangat bersih
b. Bersih
d. Kotor
e. Sangat kotor
c. Sedang 
Lokasi mana saja yang menurut Anda kotor?
a. Tugu
b. Gerbang
c. Tempat bermain skateboard
d. Jogging track
e. Lapangan rumput
f. Lainnya...

20. Lokasi mana yang paling Anda senangi?
a. Tugu
b. Gerbang
c. Tempat bermain skateboard
d. Jogging track
e. Lapangan rumput
f. Lainnya....

21. Aktivitas/kegiatan apa saja yang ingin Anda lakukan jika kawasan RTH ini akan dikembangkan lebih lanjut?

22. Apakah Anda merasa puas berkunjung ke RTH ini?
a. Sangat puas
b. Puas
c. Sedang
d. Tidak puas
e. Sangat tidak puas
23. Saran dan harapan Anda untuk taman ini:

-Terima kasih atas partisipasi AndaWassalamualaikum Wr. Wb. 
Lampiran 3 Kuesioner pengunjung Taman Kota

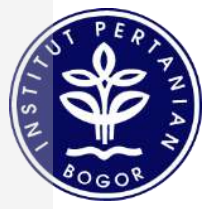

\section{DEPARTEMEN ARSITEKTUR LANSKAP FAKULTAS PERTANIAN INSTITU PERTANIAN BOGOR}

Kuesioner Penelitian

KAJIAN FUNGSI EKOLOGIS DAN ESTETIKA BEBERAPA RUANG TERBUKA

HIJAU DI KOTA TASIKMALAYA

Tanggal Pengambilan :

No. Kuesioner

Assalamualaikum Wr. Wb.

Saya Intan Nur Fathonah, mahasiswa semester 8 Departemen Arsitektur Lanskap, Institut Pertanian Bogor. Saya mengharapkan bantuan dari Bapak/Ibu/Saudara untuk mengisi kuesioner penelitian saya yang berjudul Kajian Fungsi Ekologis dan Estetika Beberapa

Ruang Terbuka Hijau di Kota Tasikmalaya. Terima kasih atas kesediaannya.

\section{Karakteristik Responden}

1. Nama

2. Umur

3. Jenis Kelamin

4. Daerah Asal

5. Pendidikan terakhir Anda:
a. SD
b. SMP
c. SMA
d. Perguruan tinggi
e. Lainnya

6. Pekerjaan/Profesi Anda saat ini:
a. Pelajar
b. Mahasiswa
c. Pegawai (Negeri/Swasta)
d. Perguruan tinggi
e. Lainnya

\section{E. Preferensi Responden}

7. Tujuan Anda mengunjungi RTH:
a. Rekreasi
b. Belajar
c. Berbelanja
d. Ingin tahu
e. Olahraga
f. Lainnya

8. Kunjungan Anda untuk:
a. Pertama kali
b. Kedua kali
c. Ketiga kali
d. Lebih dari tiga kali

9. Lama kunjungan Anda di RTH:
a. <30 menit
b. 30-60 menit
c. 1-2 jam
d. $>2$ jam

10. Frekuensi kunjungan Anda:
a. Setiap hari
b. Setiap minggu
c. Setiap bulan
d. Tidak tentu
e. Lainnya
c.............

11. Jarak RTH dari tempat tinggal anda:
a. $<500 \mathrm{~m}$
b. $500 \mathrm{~m}-1 \mathrm{~km}$
c. $>1 \mathrm{~km}$
d. $1-3 \mathrm{~km}$
e. $>3 \mathrm{~km}$

12. Aktivitas yang dilakukan di RTH:

a. Berkumpul dengan teman/keluarga

b. Duduk-duduk dan menikmati pemandangan 

c. Berjalan-jalan
d. Berfoto
e. Berolahraga
f. Lainnya.

\section{F. Presepsi Responden}

13. Kesan Anda tentang pemandangan RTH:
a. Sangat indah
b. Indah
d. Jelek
e. Sangat jelek
c. Sedang

Lokasi mana saja yang menurut Anda indah?
a. Tempat bermain anak
b. Tempat duduk
c. Spot taman
d. Lainnya

14. Kesan Anda tentang penataan tanaman RTH:
a. Sangat indah
b. Indah
d. Jelek
e. Sangat jelek
c. Sedang

Lokasi mana saja yang menurut Anda indah?
a. Tempat bermain anak
b. Tempat duduk
c. Spot taman
d. Lainnya

15. Kesan Anda tentang kenyamanan suhu di RTH:
a. Sangat sejuk
b. Sejuk
d. Panas
e. Sangat panas
c. Sedang

Lokasi mana saja yang menurut Anda sejuk?
a. Tempat bermain anak
b. Tempat duduk
d. Lainnya
c. Spot taman

16. Kesan Anda tentang kebisingan RTH:
a. Sangat tenang
b. Tenang
d. Bising
e. Sangat bising
c. Sedang

Lokasi mana saja yang menurut Anda tenang?
a. Tempat bermain anak
b. Tempat duduk
d. Lainnya...
c. Spot taman

17. Kesan Anda tentang hembusan angin pada RTH:
a. Sangat pelan
b. Pelan
c. Sedang
d. Kencang
e. Sangat kencang

Lokasi mana saja yang menurut Anda pelan?
a. Tempat bermain anak
b. Tempat duduk
d. Lainnya
c. Spot taman

18. Kesan Anda tentang kelembaban udara RTH:
a. Sangat kering
b. Kering
d. Lembab
e. Sangat lembab
c. Sedang

Lokasi mana saja yang menurut Anda lembab?
a. Tempat bermain anak
b. Tempat duduk
c. Spot taman
d. Lainnya

19. Kesan Anda tentang kebersihan RTH:
a. Sangat bersih
b. Bersih
d. Kotor
e. Sangat kotor
c. Sedang 
Lokasi mana saja yang menurut Anda kotor?
a. Tempat bermain anak
b. Tempat duduk
c. Spot taman
d. Lainnya....

20. Lokasi mana yang paling Anda senangi?
a. Tempat bermain anak
b. Tempat duduk
c. Spot taman
d. Lainnya....

21. Aktivitas/kegiatan apa saja yang ingin Anda lakukan jika kawasan RTH ini akan dikembangkan lebih lanjut?

22. Apakah Anda merasa puas berkunjung ke RTH ini?
a. Sangat puas
b. Puas
c. Sedang
d. Tidak puas
e. Sangat tidak puas

23. Saran dan harapan Anda untuk taman ini:

-Terima kasih atas partisipasi AndaWassalamualaikum Wr. Wb. 
Lampiran 4 Kuesioner pengunjung Kompleks Olahraga Wiradadaha

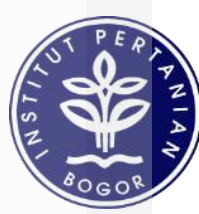

DEPARTEMEN ARSITEKTUR LANSKAP

FAKULTAS PERTANIAN

INSTITU PERTANIAN BOGOR

\section{Kuesioner Penelitian}

\section{KAJIAN FUNGSI EKOLOGIS DAN ESTETIKA BEBERAPA RUANG TERBUKA}

HIJAUDI KOTA TASIKMALAYA

Tanggal Pengambilan :

No. Kuesioner

Assalamualaikum Wr. Wb.

Saya Intan Nur Fathonah, mahasiswa semester 8 Departemen Arsitektur Lanskap, Institut Pertaniān Bogor. Saya mengharapkan bantuan dari Bapak/Ibu/Saudara untuk mengisi kuesioner penelitian saya yang berjudul Kajian Fungsi Ekologis dan Estetika Beberapa

Ruang Terbuka Hijau di Kota Tasikmalaya. Terima kasih atas kesediaannya.

\section{G. Karakteristik Responden}
1. Nama
2. Umur
3. Jenis Kelamin
4. Daerah Asal
5. Pendidikan terakhir Anda:
a. SD
b. SMP
c. SMA
d. Perguruan tinggi
e. Lainnya
6. Pekerjaan/Profesi Anda saat ini:
a. Pelajar
b. Mahasiswa
c. Pegawai (Negeri/Swasta)
d. Perguruan tinggi
e. Lainnya

H. Preferensi Responden

7. Tujuan Anda mengunjungi RTH:
a. Rekreasi
b. Belajar
d. Ingin tahu
e. Olahraga
c. Berbelanja
f. Lainnya ....

8. Kunjungan Anda untuk:
a. Pertama kali
b. Kedua kali
c. Ketiga kali
d. Lebih dari tiga kali

9. Lama kunjungan Anda di RTH:
a. $<30$ menit
b. $30-60$ menit
c. 1-2 jam
d. $>2$ jam

10. Frekuensi kunjungan Anda:
a. Setiap hari
b. Setiap minggu
c. Setiap bulan
d. Tidak tentu
e. Lainnya

11. Jarak RTH dari tempat tinggal anda:
a. $<500 \mathrm{~m}$
b. $500 \mathrm{~m}-1 \mathrm{~km}$
c. $>1 \mathrm{~km}$
d. $1-3 \mathrm{~km}$
e. $>3 \mathrm{~km}$

12. Aktivitas yang dilakukan di RTH:

a. Berkumpul dengan teman/keluarga

b. Duduk-duduk dan menikmati pemandangan 
c. Berjalan-jalan

d. Berfoto

e. Berolahraga

f. Lainnya.

\section{Presepsi Responden}

13. Kesan Anda tentang pemandangan RTH:
a. Sangat indah
b. Indah
d. Jelek
e. Sangat jelek
c. Sedang

Lokasi mana saja yang menurut Anda indah?
a. Taman Dadaha
b. Danau
d. Taman bermain anak
e. Lapangan Dadaha
c. Lapangan olahraga
f. Lainnya....

14. Kesan Anda tentang penataan tanaman RTH:
a. Sangat indah
b. Indah
d. Jelek
e. Sangat jelek
c. Sedang

Lokasi mana saja yang menurut Anda indah?
a. Taman Dadaha
b. Danau
d. Taman bermain anak
e. Lapangan
Dadaha

c. Lapangan olahraga

f. Lainnya....

15. Kesan Anda tentang kenyamanan suhu di RTH:
a. Sangat sejuk
b. Sejuk
d. Panas
e. Sangat panas
c. Sedang

Lokasi mana saja yang menurut Anda sejuk?
a. Taman Dadaha
b. Danau
d. Taman bermain anak
e. Lapangan
Dadaha

16. Kesan Anda tentang kebisingan RTH:
a. Sangat tenang
b. Tenang
d. Bising
e. Sangat bising
c. Sedang

Lokasi mana saja yang menurut Anda tenang?
a. Taman Dadaha
b. Danau
d. Taman bermain anak
e. Lapangan
Dadaha

17. Kesan Anda tentang hembusan angin pada RTH:
a. Sangat pelan
b. Pelan
c. Sedang
d. Kencang
e. Sangat kencang

c. Lapangan olahraga

f. Lainnya

Lokasi mana saja yang menurut Anda pelan?
a. Taman Dadaha
b. Danau
d. Taman bermain anak
e. Lapangan
Dadaha

c. Lapangan olahraga

f. Lainnya

18. Kesan Anda tentang kelembaban udara RTH:
a. Sangat kering
b. Kering
d. Lembab
e. Sangat lembab
c. Sedang

Lokasi mana saja yang menurut Anda lembab?
a. Taman Dadaha
b. Danau
c. Lapangan olahraga 

d. Taman bermain anak
e. Lapangan
Dadaha
f. Lainnya.

19. Kesan Anda tentang kebersihan RTH:
a. Sangat bersih
b. Bersih
c. Sedang
d. Kotor
e. Sangat kotor

Lokasi mana saja yang menurut Anda kotor?
a. Taman Dadaha
b. Danau
c. Lapangan olahraga
d. Taman bermain anak
e. Lapangan
f. Lainnya.
Dadaha

20. Lokasi mana yang paling Anda senangi?
a. Taman Dadaha
b. Danau
c. Lapangan olahraga
d. Taman bermain anak
e. Lapangan
Dadaha
f. Lainnya.

21. Aktivitas/kegiatan apa saja yang ingin Anda lakukan jika kawasan RTH ini akan dikembangkan lebih lanjut?

22. Apakah Anda merasa puas berkunjung ke RTH ini?
a. Sangat puas
b. Puas
c. Sedang
d. Tidak puas
e. Sangat tidak puas

23. Saran dan harapan Anda untuk taman ini:

\section{-Terima kasih atas partisipasi Anda- Wassalamualaikum Wr. Wb.}


Lampiran 5 Kuesioner Scenic Beauty Estimation

KUESIONER

Kajian Fungsi Ekologis dan Estetika Beberapa

Ruang Terbuka Hijau di Kota Tasikmalaya

\section{Data Responden \\ Jenis Kelamin \\ Usia \\ Departemen \\ Semester}

Skala Penilaian Responden

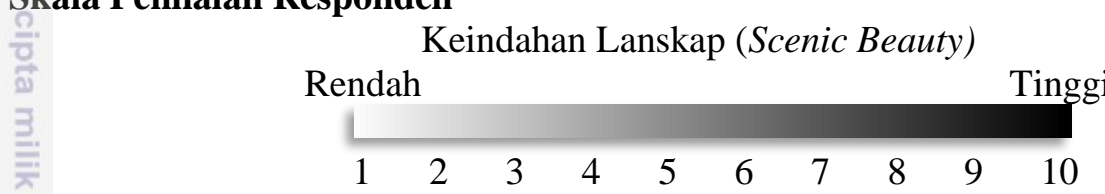

Penilaian Lanskap

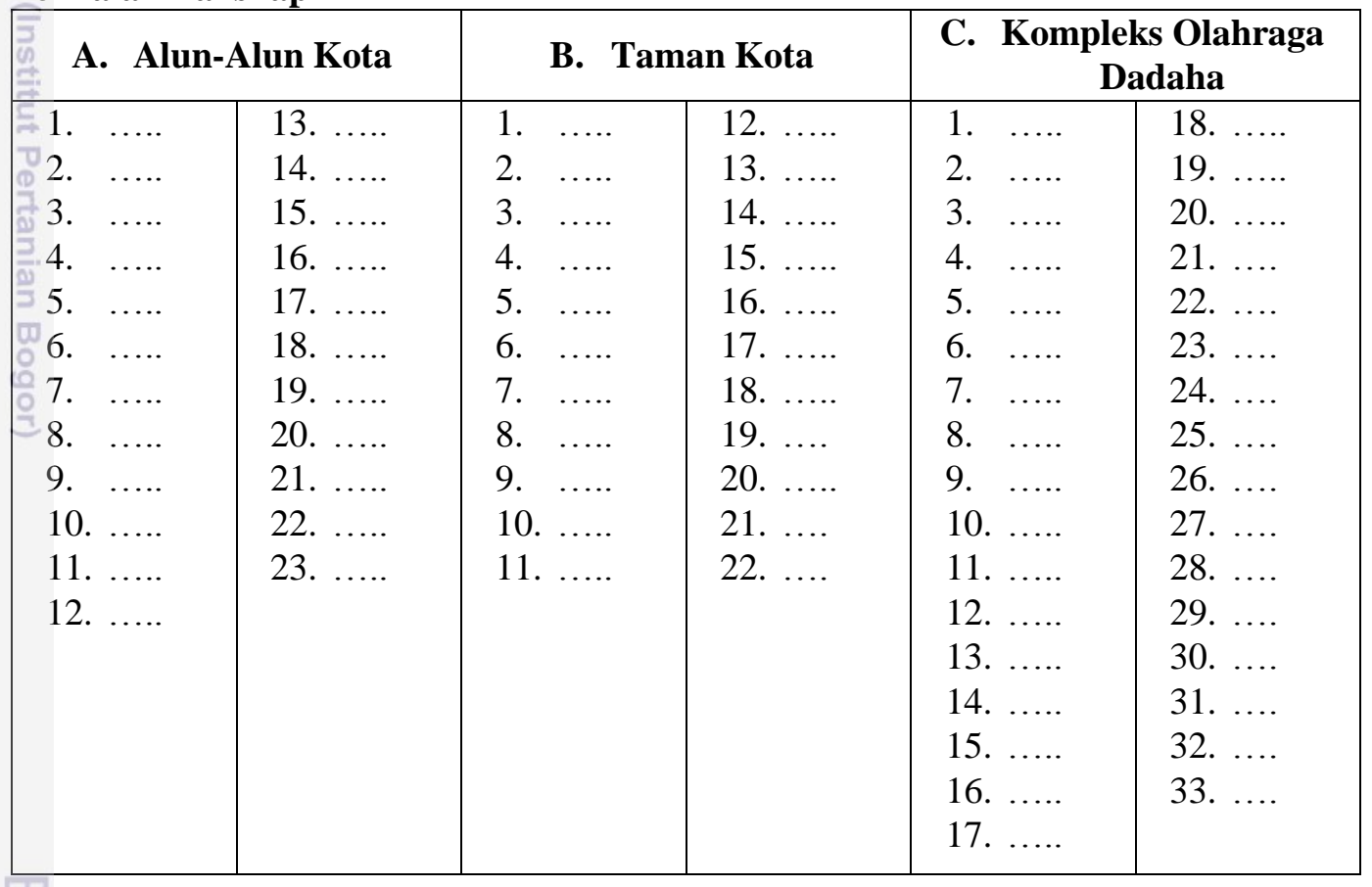

Komentar:

-Terima Kasih- 
Lampiran 6 Foto lanskap Alun-alun

Kualitas Estetika Tinggi

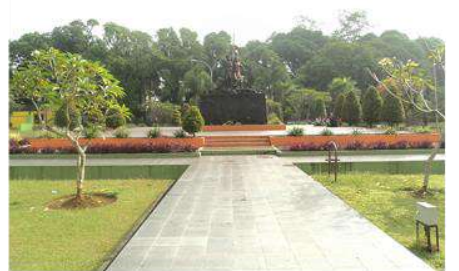

Lanskap $2(\mathrm{SBE}=24.9)$

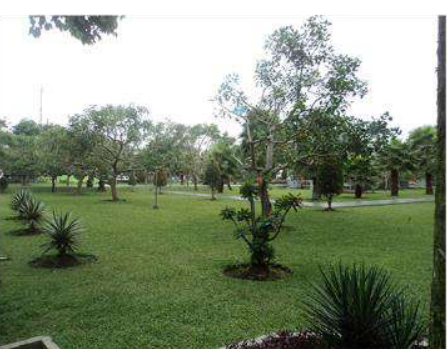

Lanskap $10(\mathrm{SBE}=25.4)$

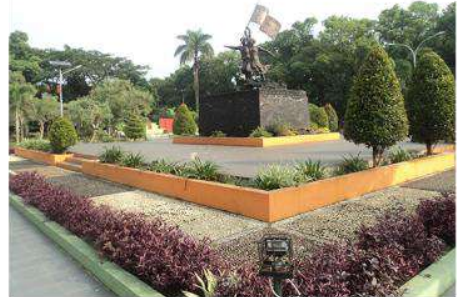

Lanskap $4(\mathrm{SBE}=40.2)$

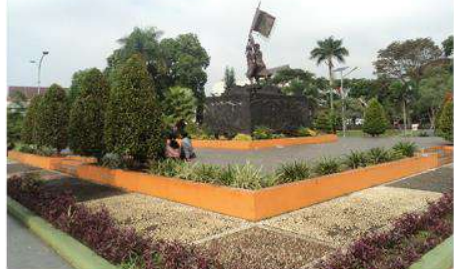

Lanskap $12(\mathrm{SBE}=31.4)$

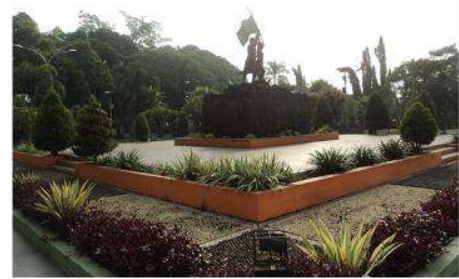

Lanskap $23(\mathrm{SBE}=36.9)$

Kualitas Estetika Sedang

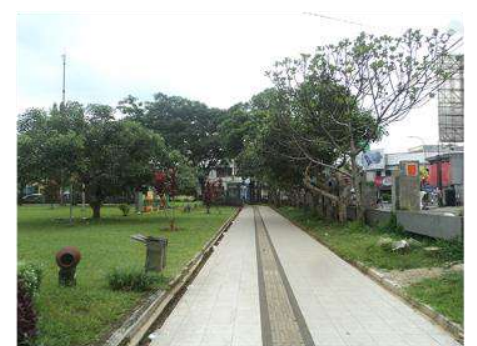

Lanskap $3(\mathrm{SBE}=-16)$

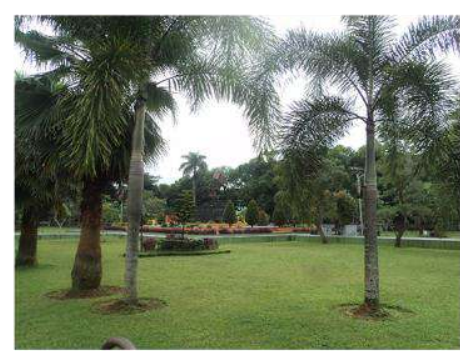

Lanskap $6(\mathrm{SBE}=3.11)$

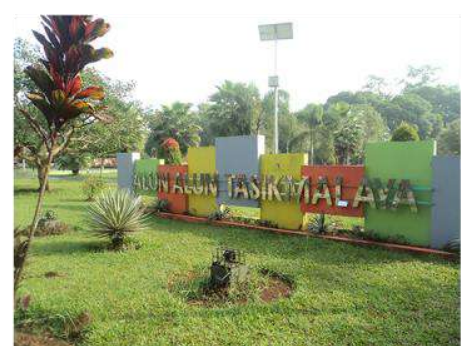

Lanskap $5(\mathrm{SBE}=-18)$

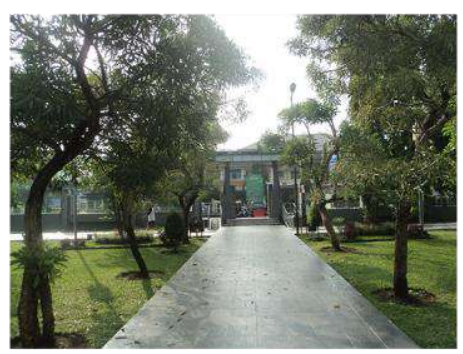

Lanskap $8(\mathrm{SBE}=0)$ 
Lampiran 6 Foto lanskap Alun-alun (lanjutan)

Kualitas Estetika Sedang
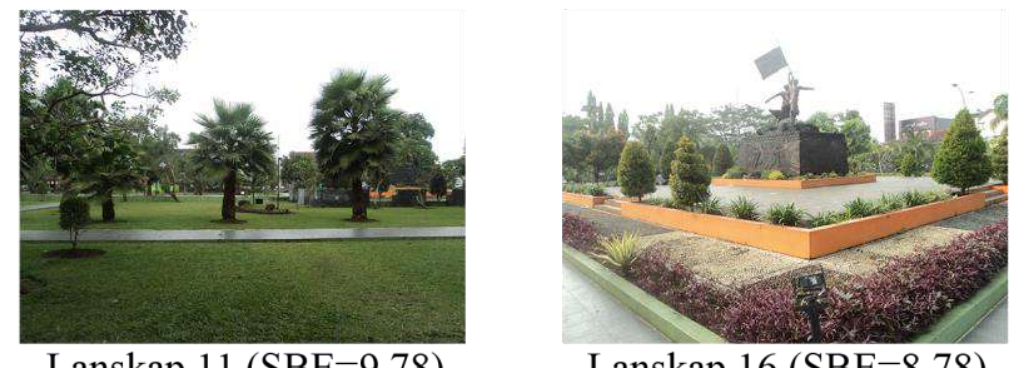

Lanskap 11 (SBE=9.78)

Lanskap $16(\mathrm{SBE}=8.78)$
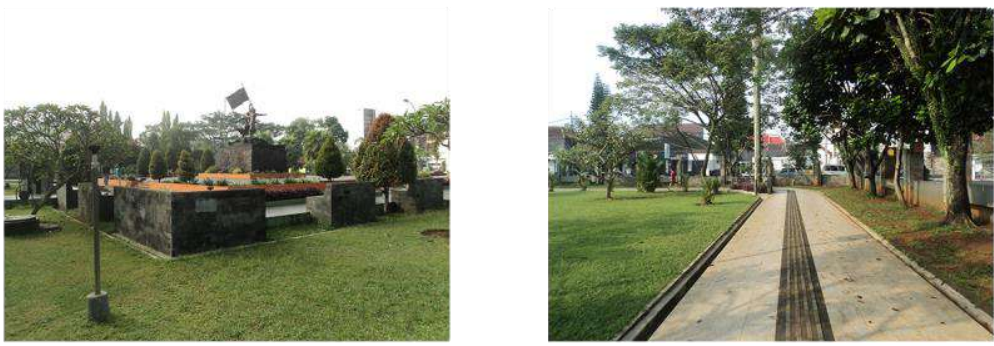

Lanskap 18 (SBE=3.11)

Lanskap $19(\mathrm{SBE}=-15)$

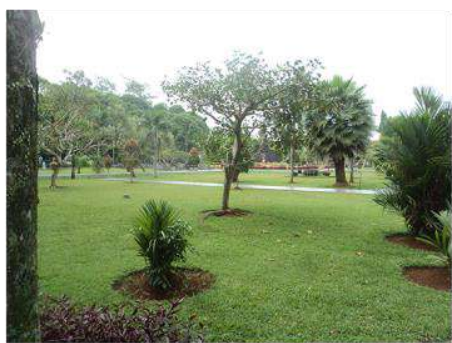

Lanskap $20(\mathrm{SBE}=4.89)$

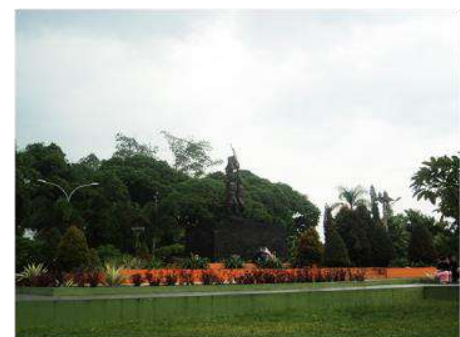

Lanskap $21(\mathrm{SBE}=4.67)$

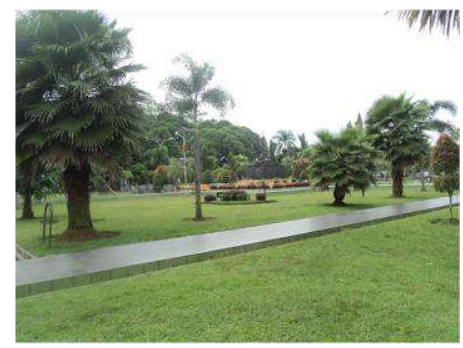

Lanskap $22(\mathrm{SBE}=17.3)$ 
Lampiran 6 Foto lanskap Alun-alun (lanjutan)

Kualitas Estetika Rendah

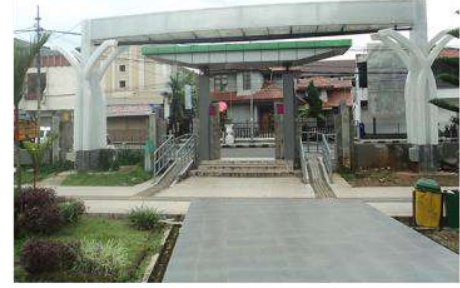

Lanskap $1(\mathrm{SBE}=-45)$

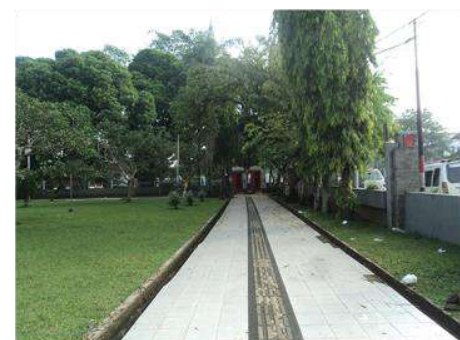

Lanskap $9(\mathrm{SBE}=-28)$

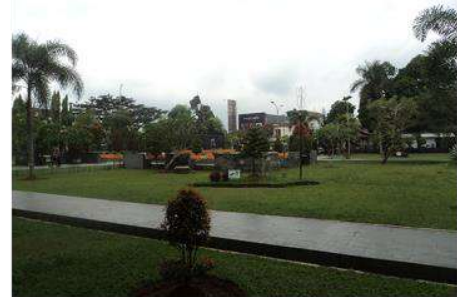

Lanskap $14(\mathrm{SBE}=-32)$

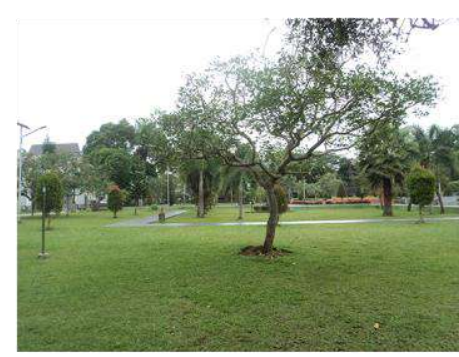

Lanskap 7 (SBE=-24)

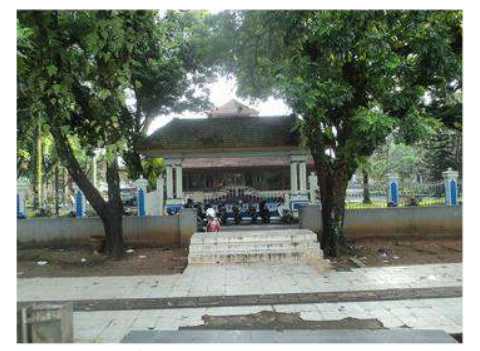

Lanskap 13 (SBE=-70)

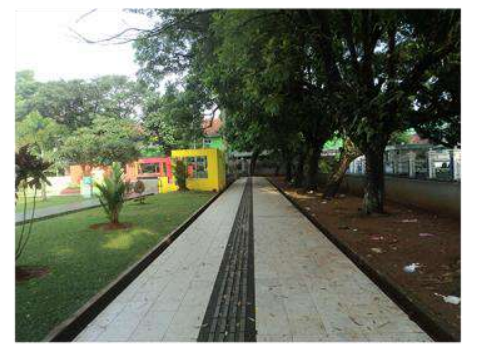

Lanskap $15(\mathrm{SBE}=-40)$

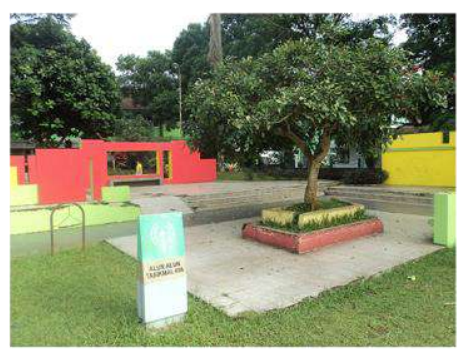

Lanskap 17 (SBE=-21) 
Lampiran 7 Foto lanskap Taman Kota

Kualitas Estetika Tinggi

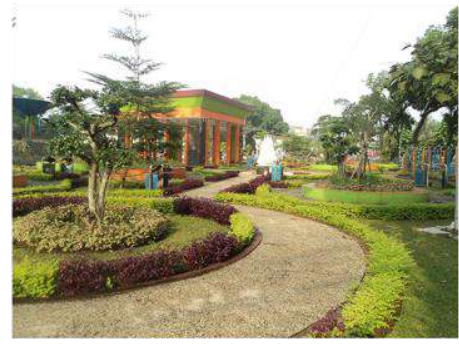

Lanskap $1(\mathrm{SBE}=41.4)$

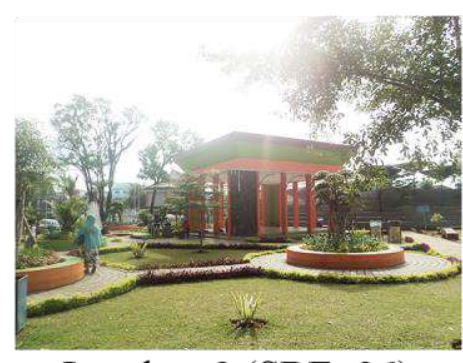

Lanskap $8(\mathrm{SBE}=26)$

Kualitas Estetika Sedang

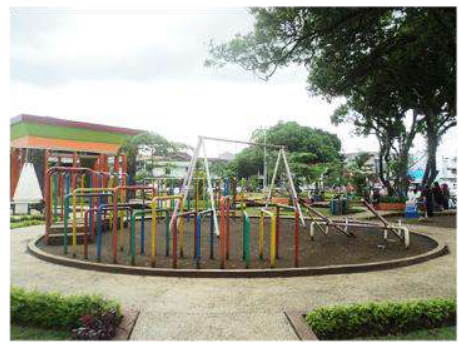

Lanskap $2(\mathrm{SBE}=0)$
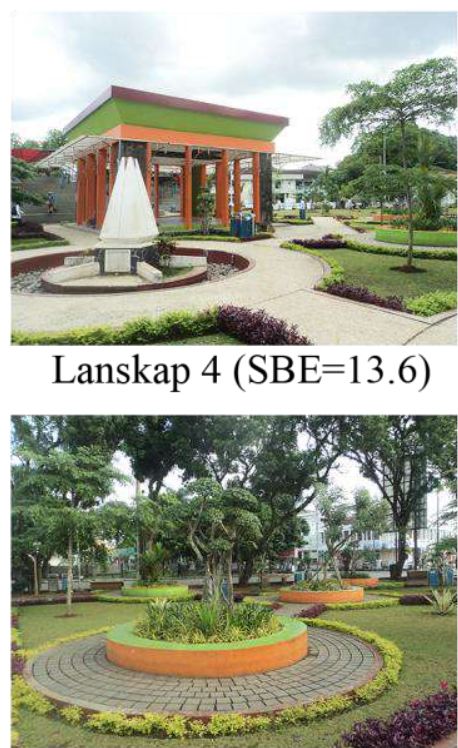

Lanskap 7 (SBE=13.8)

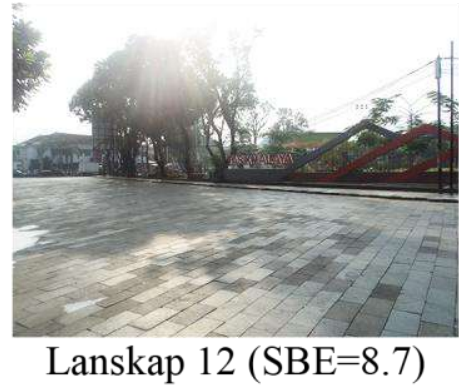

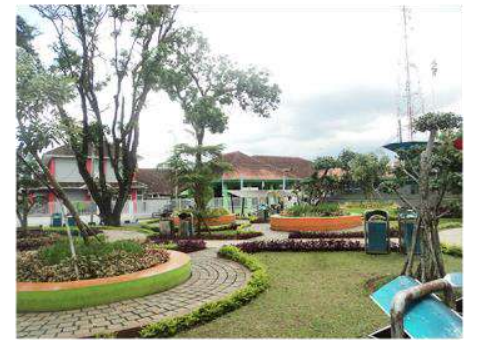

Lanskap $3(\mathrm{SBE}=-9.2)$

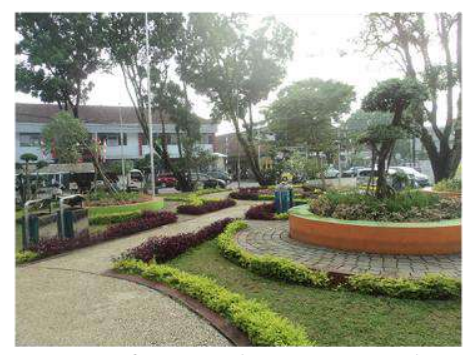

Lanskap $5(\mathrm{SBE}=17.5)$

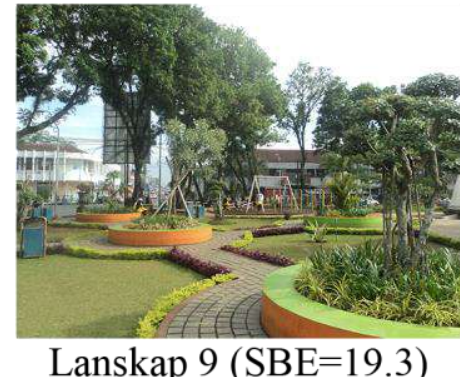

(SBE=19.3)

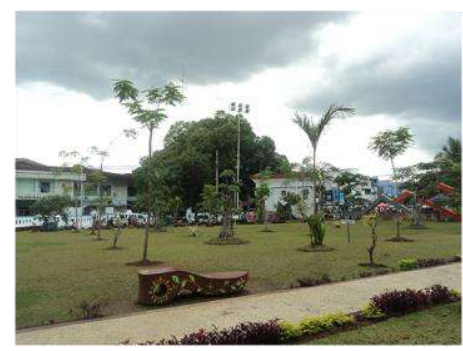

Lanskap $14(\mathrm{SBE}=-18.4)$ 
Lampiran 7 Foto lanskap Taman Kota (lanjutan)

Kualitas Estetika Sedang

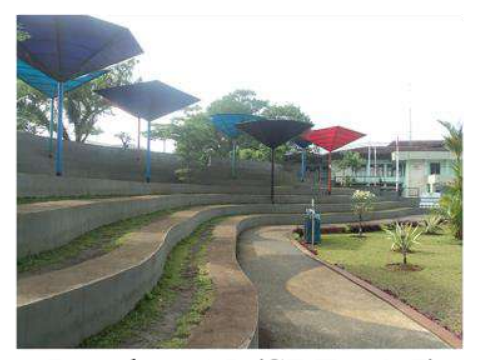

Lanskap $15(\mathrm{SBE}=-3.7)$

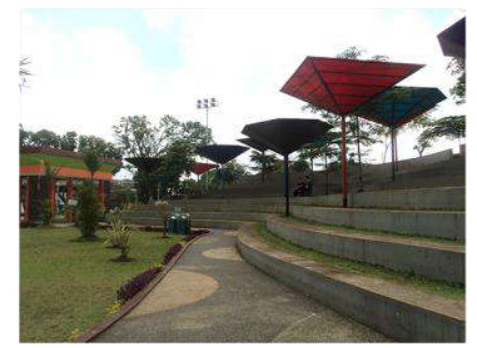

Lanskap $18(\mathrm{SBE}=8.1)$

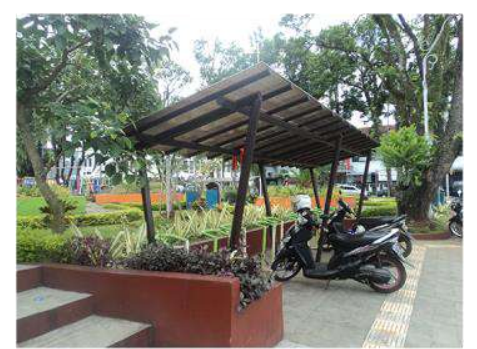

Lanskap $20(\mathrm{SBE}=8.3)$

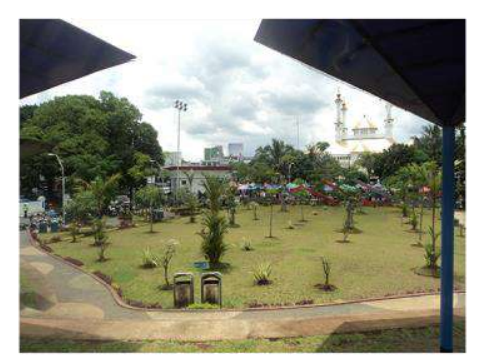

Lanskap $17(\mathrm{SBE}=5.4)$

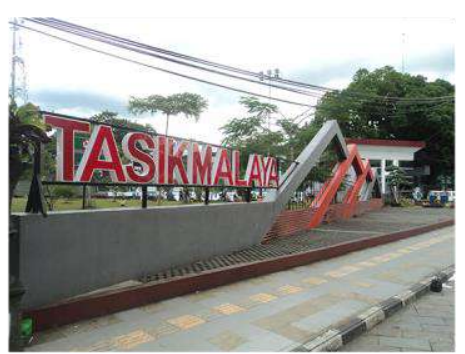

Lanskap $19(\mathrm{SBE}=2.7)$

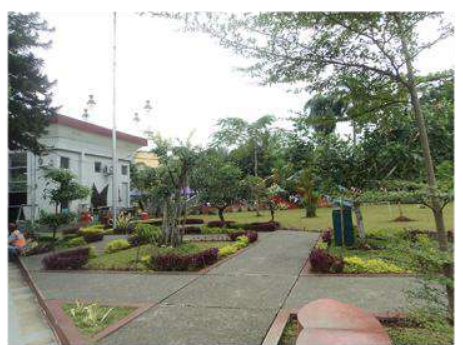

Lanskap $21(\mathrm{SBE}=8)$

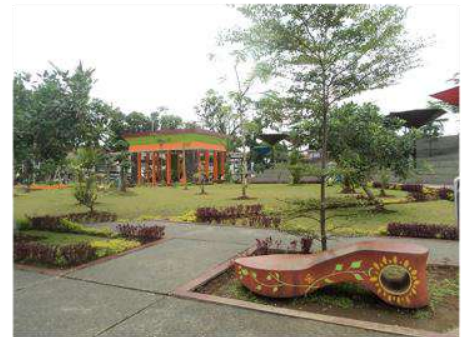

Lanskap $22(\mathrm{SBE}=0.3)$

Kualitas Estetika Rendah

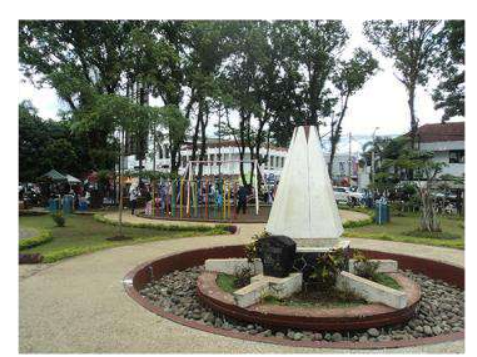

Lanskap $6(\mathrm{SBE}=-32.3)$

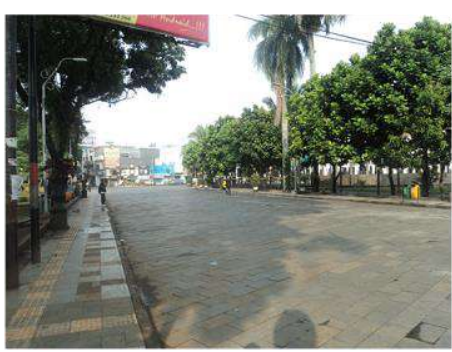

Lanskap $10(\mathrm{SBE}=-35.6)$ 
Lampiran 7 Foto lanskap Taman Kota (lanjutan)

Kualitas Estetika Rendah

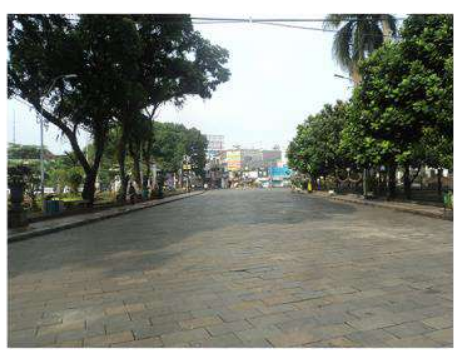

Lanskap $11(\mathrm{SBE}=-37.8)$

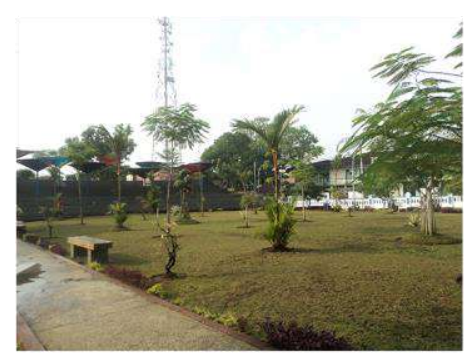

Lanskap $13(\mathrm{SBE}=-37.4)$

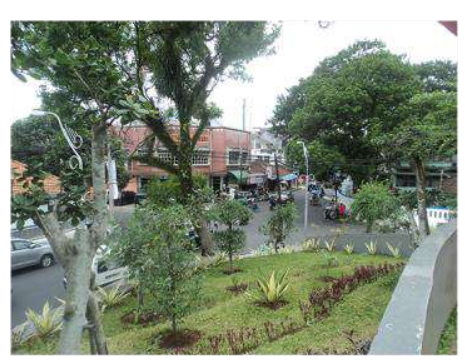

Lanskap $16(\mathrm{SBE}=-23.2)$ 
Lampiran 8 Foto lanskap Kompleks Olahraga Wiradadaha

Kualitas Estetika Sedang

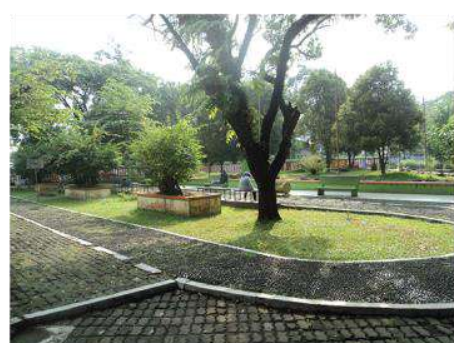

Lanskap $6(\mathrm{SBE}=-1.8)$

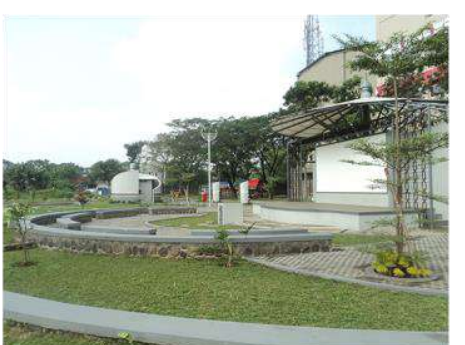

Lanskap $12(\mathrm{SBE}=-5.57)$

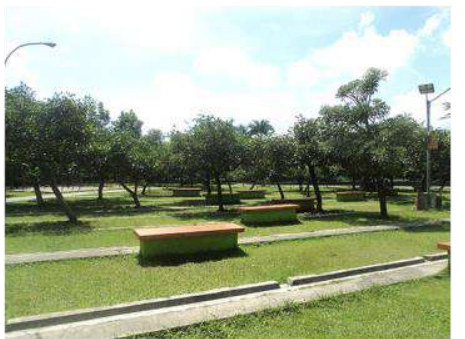

Lanskap $18(\mathrm{SBE}=0)$

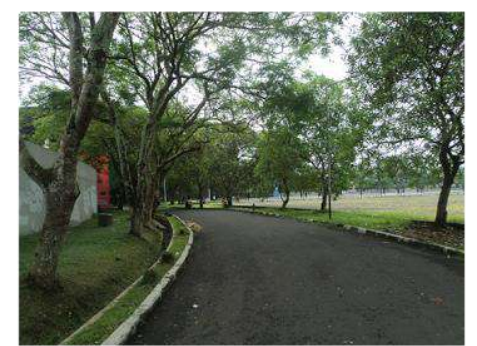

Lanskap $27(\mathrm{SBE}=-19.7)$

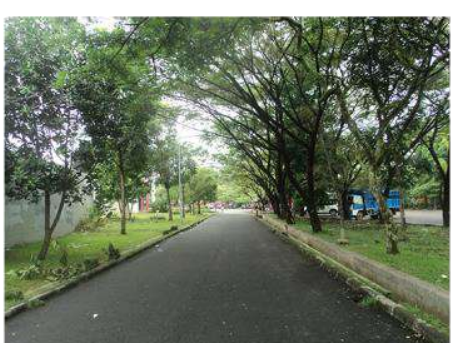

Lanskap 7 (SBE=-13.2)

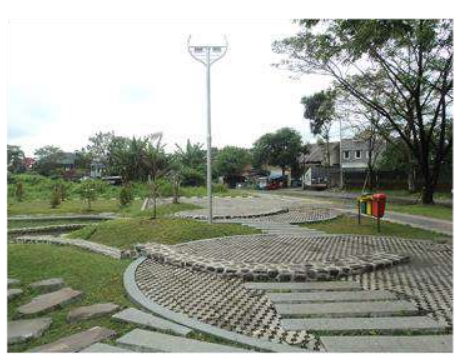

Lanskap $13(\mathrm{SBE}=-10.8)$

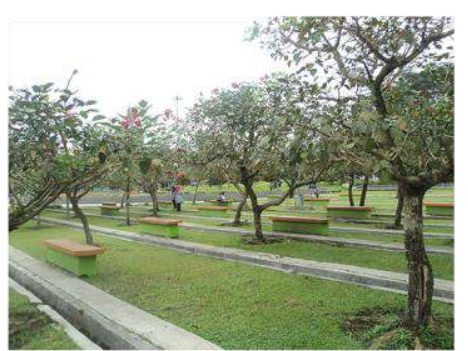

Lanskap $19(\mathrm{SBE}=-11.1)$

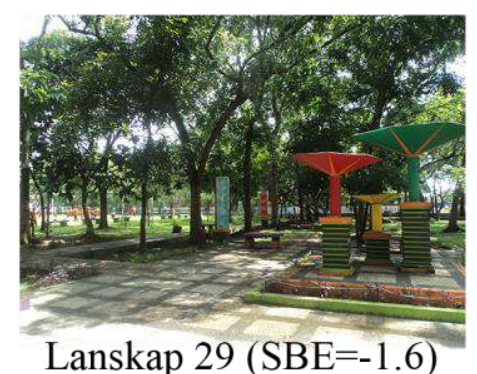

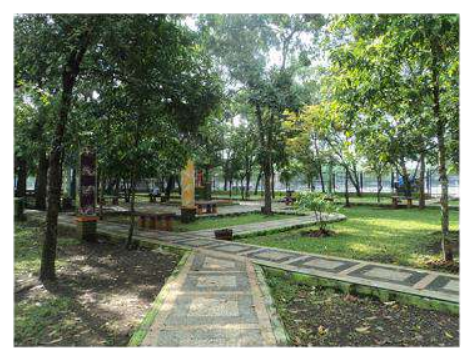

Lanskap $30(\mathrm{SBE}=-12.4)$ 
Lampiran 8 Foto lanskap Kompleks Olahraga Wiradadaha (lanjutan)

\section{Kualitas Estetika Rendah}

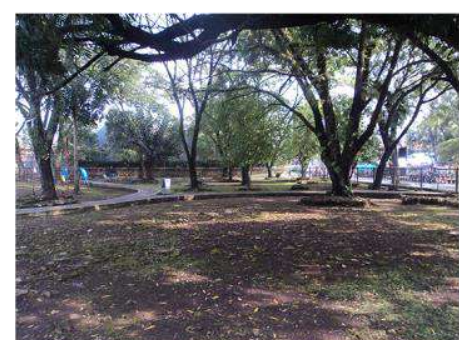

Lanskap $1(\mathrm{SBE}=-53.7)$

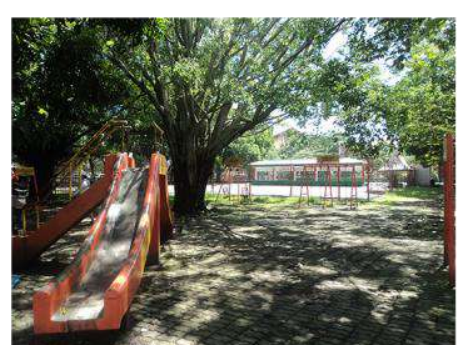

Lanskap $3(\mathrm{SBE}=-40.5)$

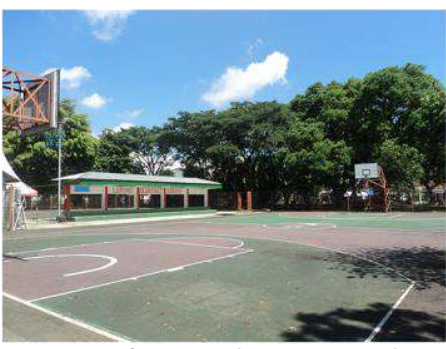

Lanskap $5(\mathrm{SBE}=-27)$

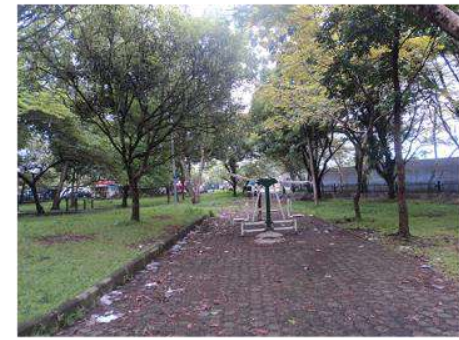

Lanskap $9(\mathrm{SBE}=-98.2)$

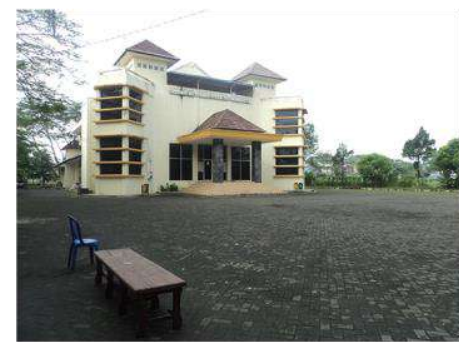

Lanskap $11(\mathrm{SBE}=-63.4)$

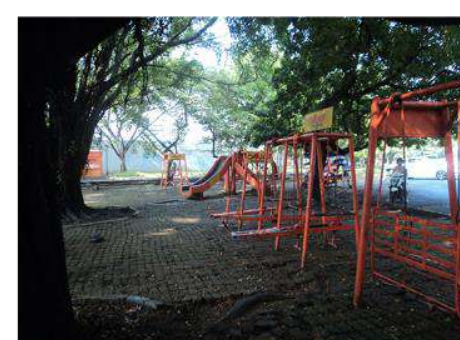

Lanskap 2 (SBE=-49.9)

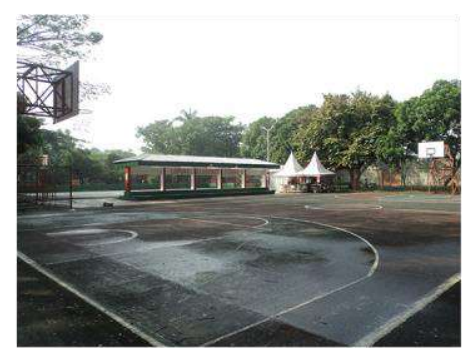

Lanskap $4(\mathrm{SBE}=-31)$

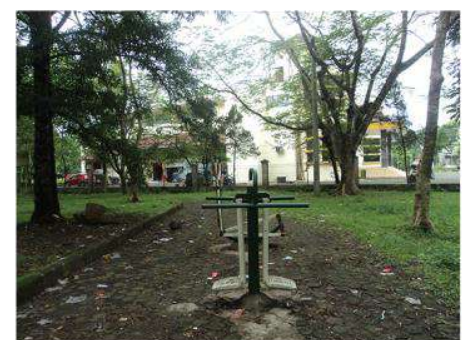

Lanskap $8(\mathrm{SBE}=-101)$

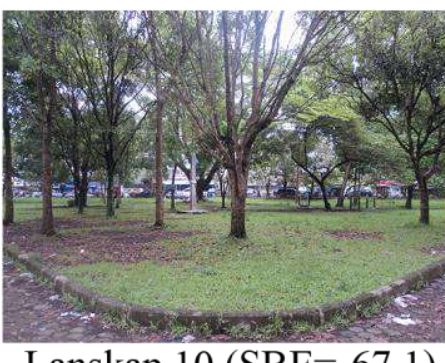

Lanskap 10 (SBE=-67.1)

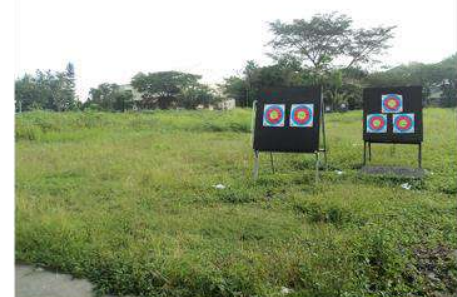

Lanskap $14(\mathrm{SBE}=-70.3)$ 
Lampiran 8 Foto lanskap Kompleks Olahraga Wiradadaha (lanjutan)

\section{Kualitas Estetika Rendah}

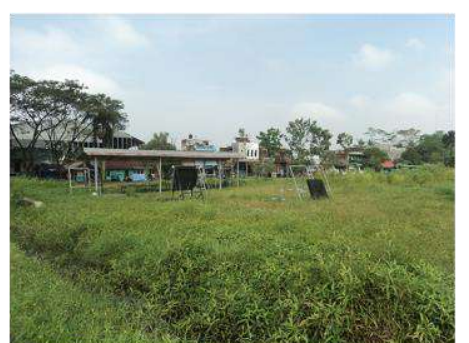

Lanskap $15(\mathrm{SBE}=-86.5)$

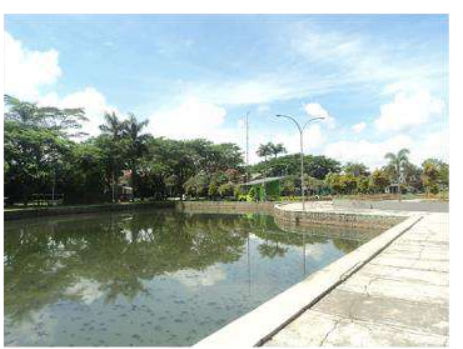

Lanskap $17(\mathrm{SBE}=-26)$

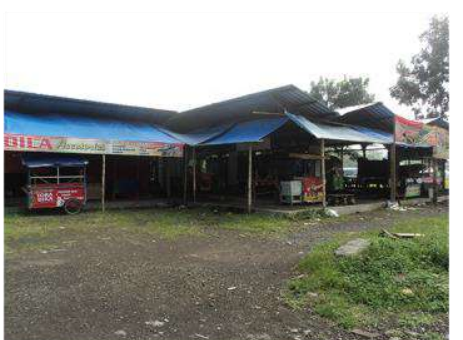

Lanskap $21(\mathrm{SBE}=-104)$

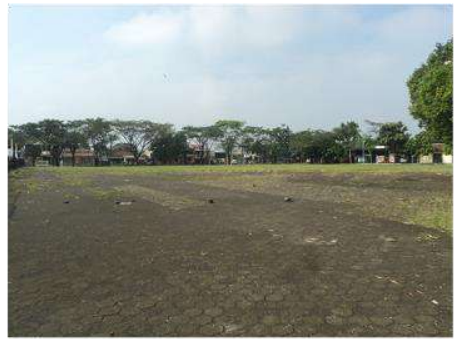

Lanskap 23 (SBE=-63.2)

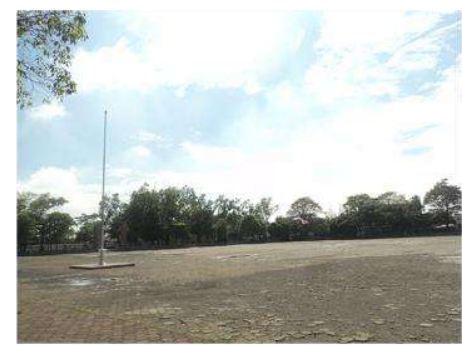

Lanskap $25(\mathrm{SBE}=-54)$

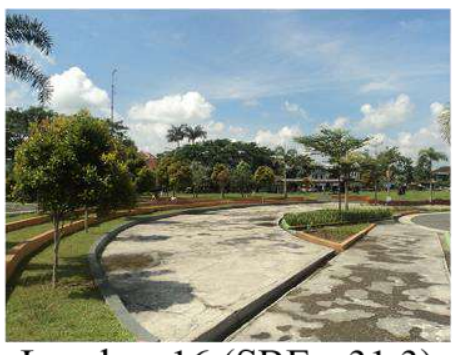

Lanskap $16(\mathrm{SBE}=-31.3)$

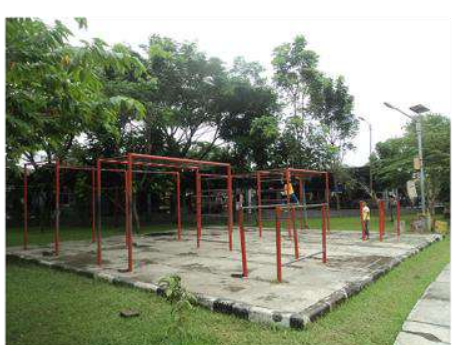

Lanskap $20(\mathrm{SBE}=-36.8)$

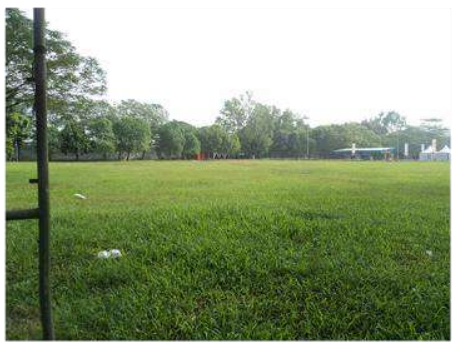

Lanskap $22(\mathrm{SBE}=-59.1)$

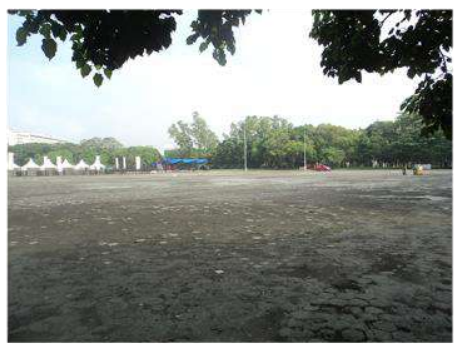

Lanskap $24(\mathrm{SBE}=-55)$

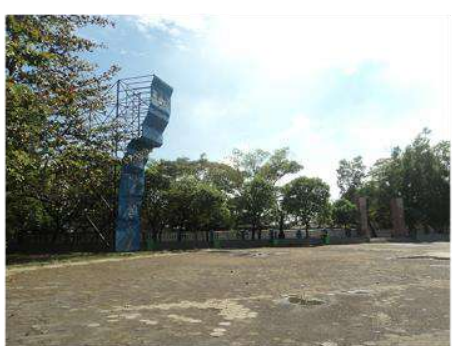

Lanskap $26(\mathrm{SBE}=-47.4)$ 
Lampiran 8 Foto lanskap Kompleks Olahraga Wiradadaha (lanjutan)

Kualitas Estetika Rendah

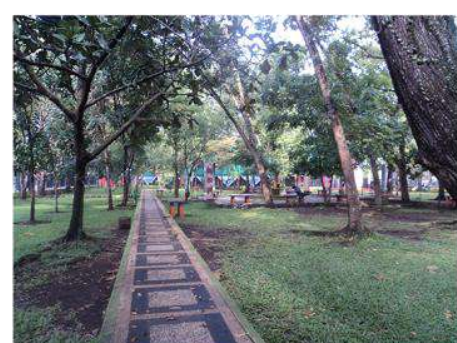

Lanskap $28(\mathrm{SBE}=-22.8)$

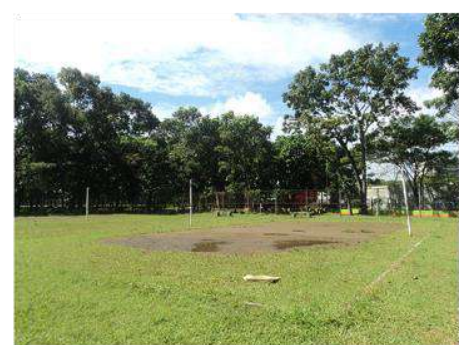

Lanskap 32 (SBE=-70.3)

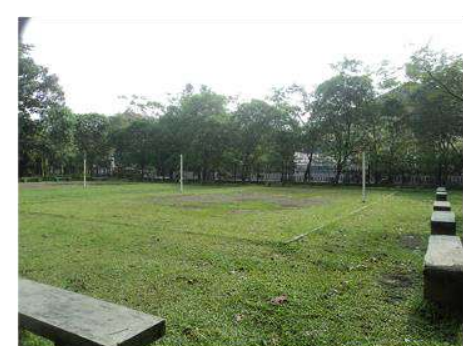

Lanskap $31(\mathrm{SBE}=-45.5)$

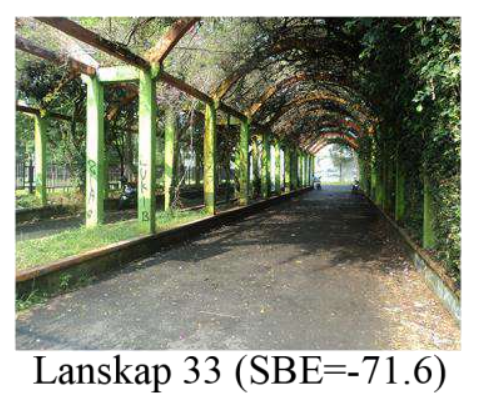


(180.

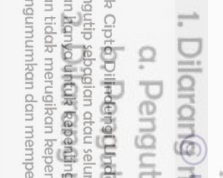

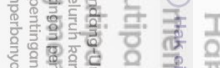

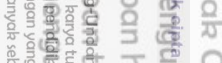

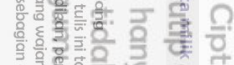

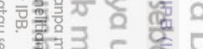

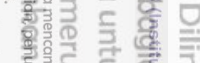

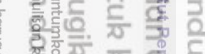

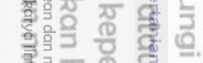

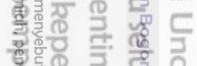

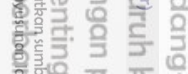

悹地

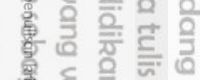

雾.

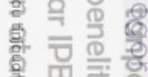

올

3

㶾

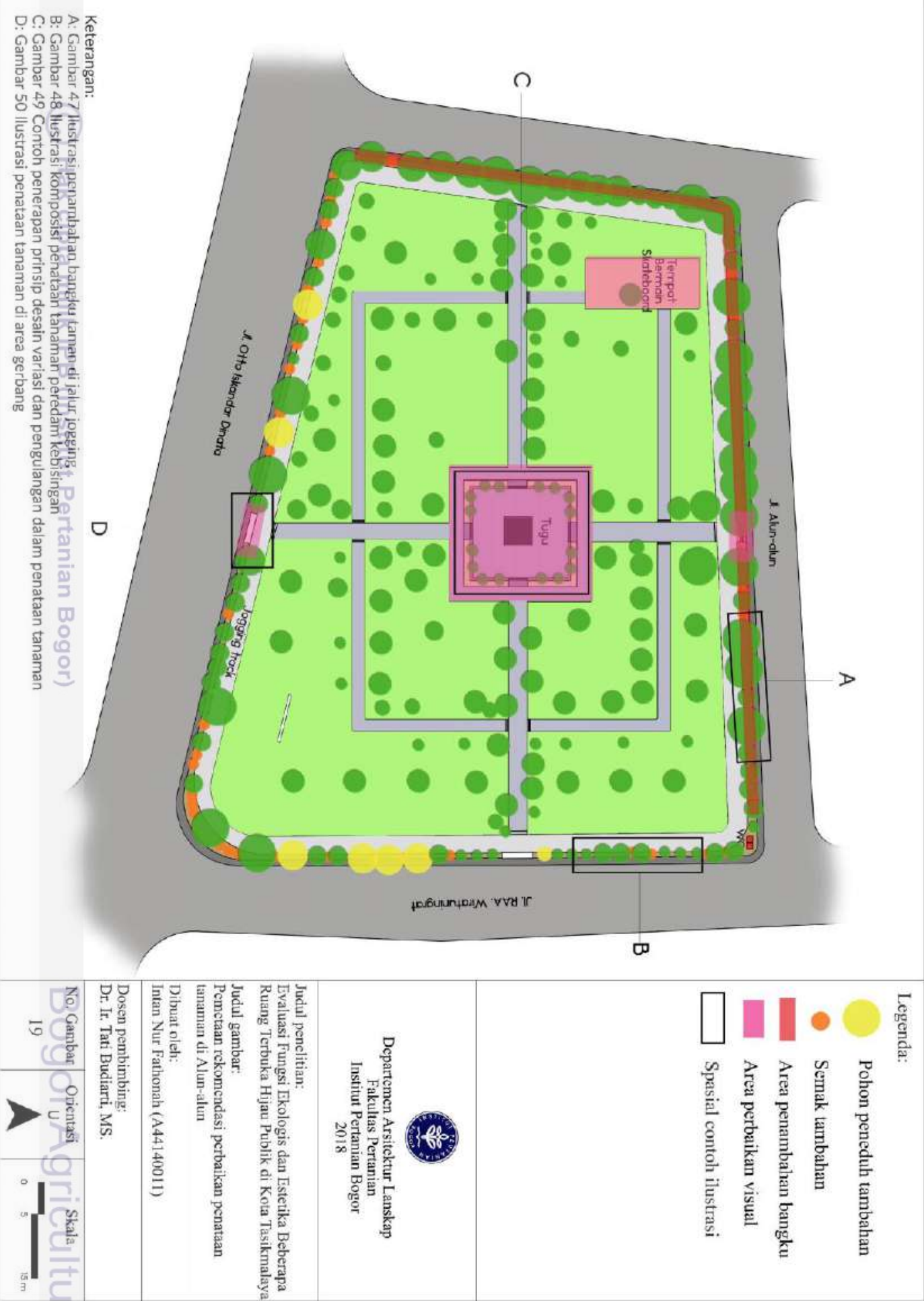

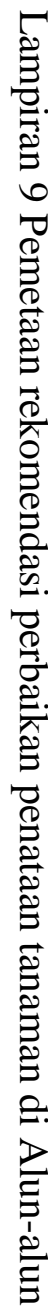


(19)<smiles>C1CCCC1</smiles>

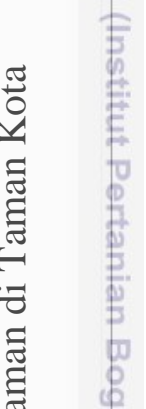
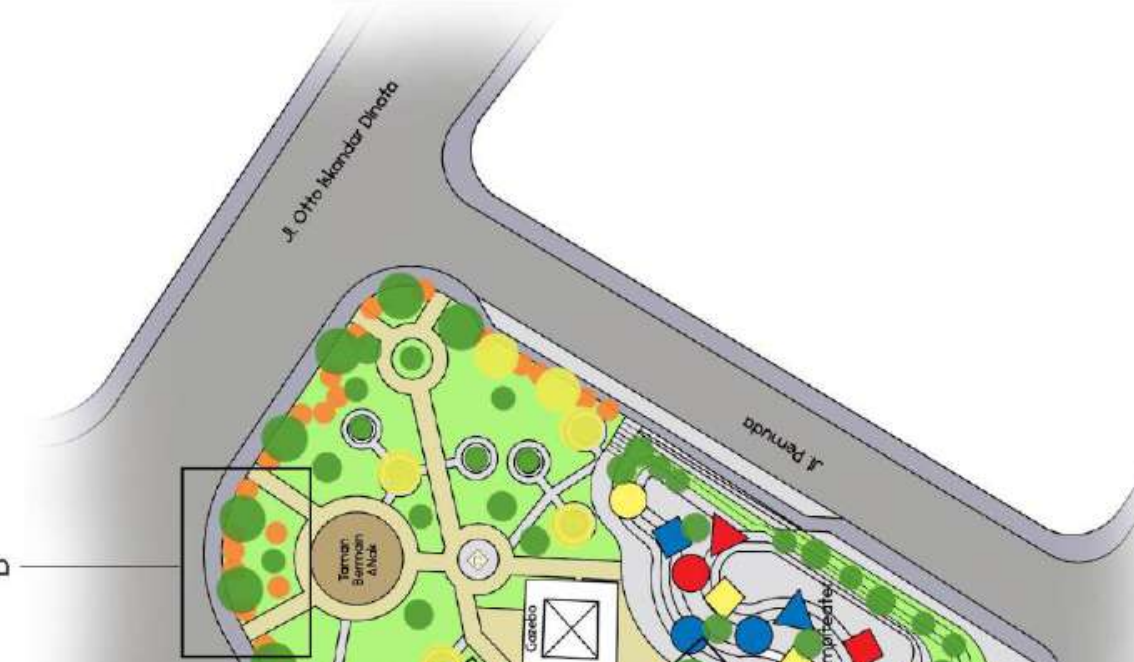

สี

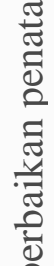
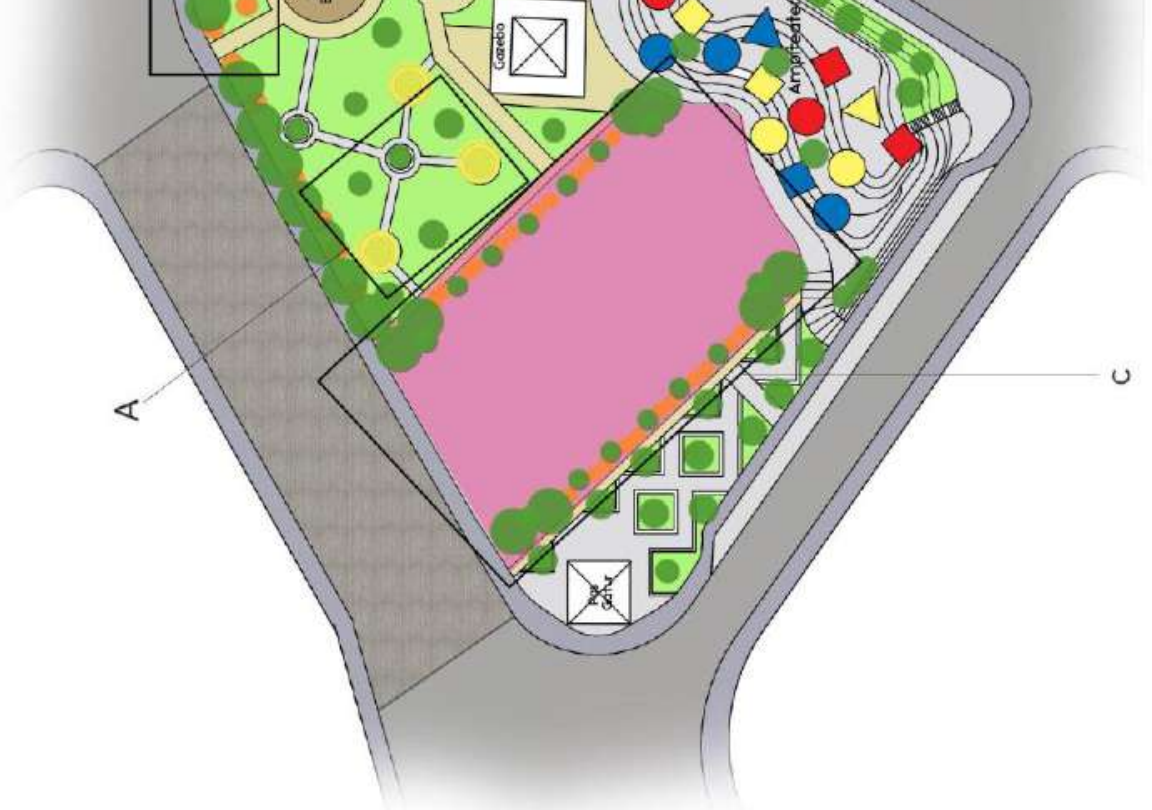

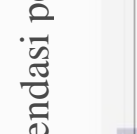


6

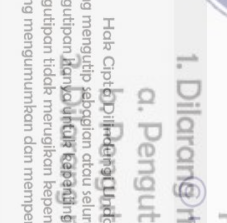

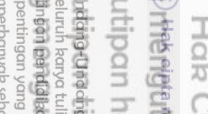

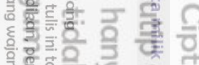

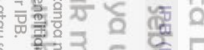

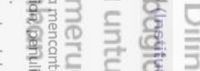

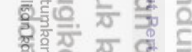

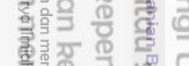

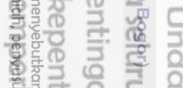

ㅎํㄹ.

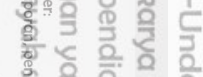

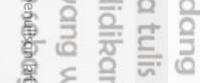

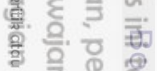

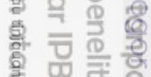

옥 क्ञ

क्षे

言

족

용

产. $\frac{2}{5}$

造

这

窟

을

()

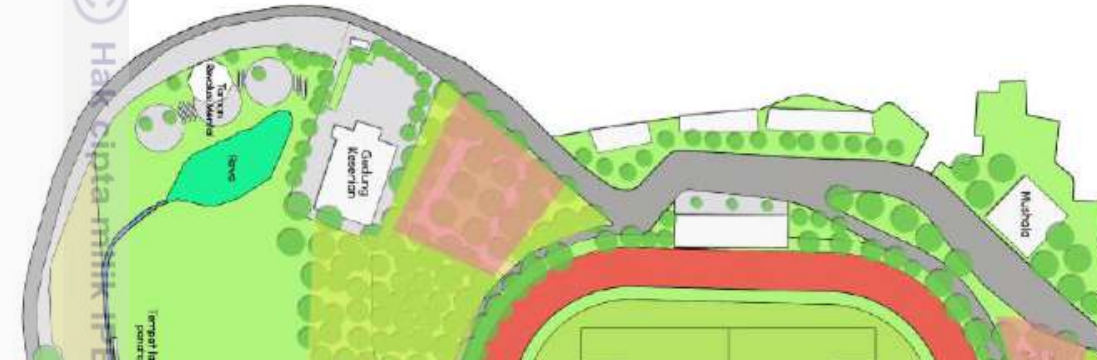

葛

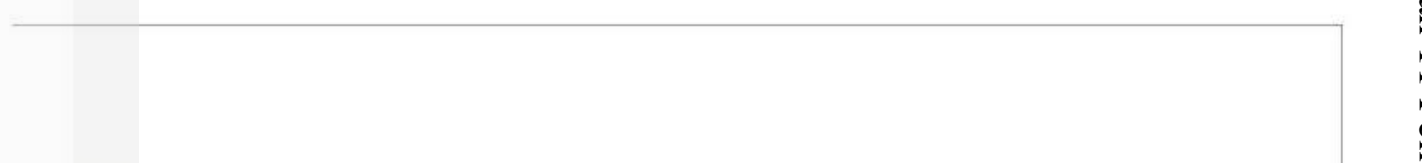

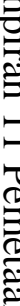

$\overrightarrow{0}$

승

จิ

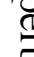

青毫

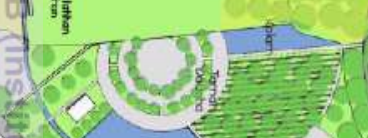

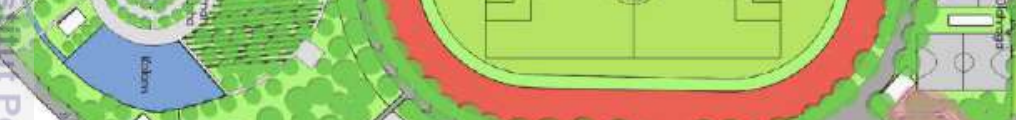

व)

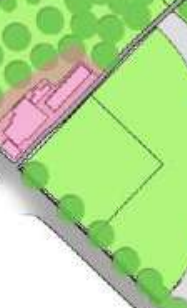

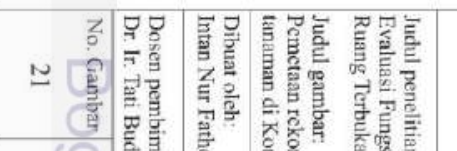

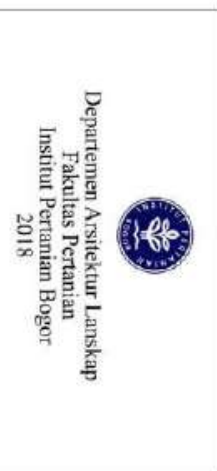

(9)
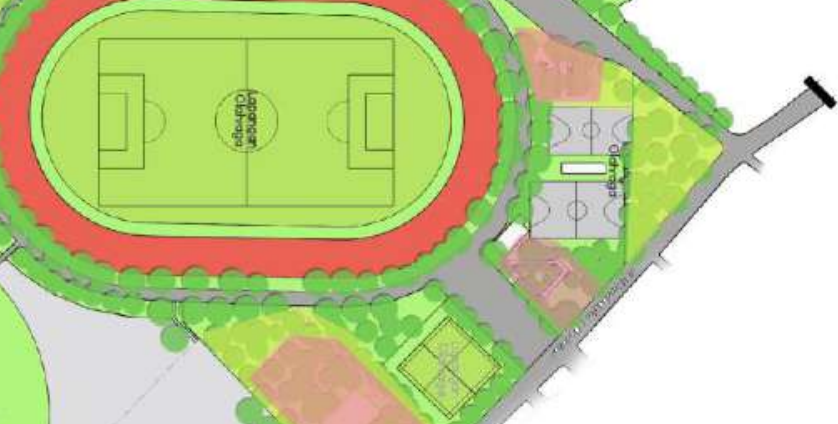

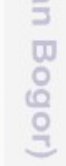

(re

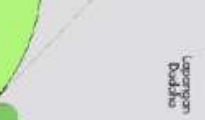

绕

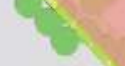

?.

중

莺 


\section{RIWAYAT HIDUP}

Penulis dilahirkan di Tasikmalaya pada tanggal 14 Agustus 1995 dari pasangan Bapak Tommi Kosman dan Ibu Eli Yulia. Penulis merupakan anak ketiga dari tiga bersaudara. Kedua kakak perempuan penulis bernama Siti Rahmi Nur Utami dan Dita Nur Ilhami.

Penulis memulai pendidikan di TK Perwari pada tahun 2001. Penulis melanjutkan pendidikan formalnya ke SD Pengadilan 2 dan lulus pada tahun 2008. Penulis beranjak ke bangku SMP Al-Muttaqin hingga lulus pada tahun 2011. Penulis kemudian melanjutkan pendidikannya ke SMAN 2 Tasikmalaya dan lulus pada tahun 2014. Penulis kemudian mengikuti Seleksi Nasional Masuk Perguruan Tinggi Negeri (SNMPTN) dan lolos ke pilihan pertamanya di Departemen Arsitektur Lanskap, Fakultas Pertanian, Institut Pertanian Bogor.

Selama masa perkuliahan, penulis aktif menjadi sekretaris Himpunan Mahasiswa Tasikmalaya (HIMALAYA) periode tahun 2015/2016, layouter Koran Kampus dari tahun 2015-2016, dan menjadi anggota Divisi Komunikasi dan Informasi Forum Komunikasi Rohis Departeman (FKRD) Fakultas Pertanian periode tahun 2016/2017. Penulis turut menjadi asisten mata kuliah keagamaan Islam periode tahun 2016/2017. Penulis juga aktif dalam berbagai kepanitiaan sejak Tingkat Persiapan Bersama (TPB) seperti kepanitiaan acara ESSENTIAL BEM TPB, AGRI ACT: IPB Goes to School 2016, The 3rd Biannual Returnee Seminar BEM KM, The 9th International Scholarship and Education Expo (ISEE) BEM KM, SALAM ISC 1437 H, dan kepanitiaan angkatan di Departemen Arstiketur Eanskap.

Penulis sempat mengikuti beberapa perlombaan. Meskipun tidak mendapat juara pertama, penulis cukup bangga menjadi juara 3 Islamic Poster Competition di acara IPB Islamic Festival 2016. Penulis juga menjadi finalis di IPB Essay Competition "Sustainable Development Goals" dari BEM FEMA IPB dan finalis Science Paper Competition, BENTANG ITB 2017 dari HIMABIO ITB. 